\title{
EFEITOS DA APLICAÇÃO DE BIOSSÓLIDO NO CRESCIMENTO E NUTRIÇÃO MINERAL DE MUDAS DE QUATRO ESPÉCIES FLORESTAIS NATIVAS UTILIZADAS NA ARBORIZAÇÃO URBANA
}

\section{ARY VIEIRA DE PAIVA}

Engenheiro Agrônomo

Orientador: Prof. Dr. FÁBIO POGGIANI

Tese apresentada à Escola Superior de Agricultura "Luiz de Queiroz", Universidade de São Paulo, para obtenção do título de Doutor em Recursos Florestais, com opção em Conservação de Ecossistemas Florestais.

PIRACICABA

Estado de São Paulo - Brasil

Abril - 2005 


\section{Errata}

Tabela 6. Parâmetros de caracterização do biossólido gerado pela ETE de Barueri, utilizado no experimento. (Lodo seco termicamente e granulado)

\begin{tabular}{llr}
\hline PARÅMETROS & UNIDADE & AMOSTRA \\
\hline pH (água-relação 1:5) & & 7 \\
Umidade 65 C & $\mathrm{g} \mathrm{kg-1}^{\circ}$ & 60,61 \\
C orgânico & $\mathrm{g} \mathrm{kg-1}^{-1}$ & 333,89 \\
Matéria orgânica total & $\mathrm{g} \mathrm{kg-1}^{-1}$ & 564,6 \\
Condutividade & $\mathrm{mS}^{\mathrm{cm}}$ & 3,68 \\
$\mathrm{~N}$ kjeldahl & $\mathrm{g} \mathrm{kg-1}^{-1}$ & 39,64 \\
$\mathrm{P}$ & $\mathrm{g} \mathrm{kg-1}^{-1}$ & 17,01 \\
$\mathrm{~K}$ & $\mathrm{~g} \mathrm{kg-1}^{-1}$ & 1,88 \\
$\mathrm{Ca}$ & $\mathrm{g} \mathrm{kg-1}^{-1}$ & 32,67 \\
$\mathrm{Mg}$ & $\mathrm{g} \mathrm{kg-1}^{-1}$ & 4,11 \\
$\mathrm{Na}$ & $\mathrm{g} \mathrm{kg-1}^{-1}$ & 0,73 \\
$\mathrm{~S}$ & $\mathrm{~g} \mathrm{kg-1}^{-1}$ & $\mathrm{na}$ \\
$\mathrm{Mn}$ & $\mathrm{mg} \mathrm{kg-1}^{-1}$ & 4.113 \\
$\mathrm{Fe}$ & $\mathrm{mg} \mathrm{kg-1}^{-1}$ & 38.283 \\
$\mathrm{Al}$ & $\mathrm{mg} \mathrm{kg-1}^{-1}$ & 27.821 \\
$\mathrm{Zn}$ & $\mathrm{mg} \mathrm{kg-1}^{-1}$ & 3.037 \\
$\mathrm{Ni}$ & $\mathrm{mg} \mathrm{kg-1}^{-1}$ & 316 \\
$\mathrm{Cu}$ & $\mathrm{mg} \mathrm{kg-1}^{-1}$ & 848 \\
$\mathrm{Cr}$ total & $\mathrm{mg} \mathrm{kg-1}^{-1}$ & 700 \\
$\mathrm{~Pb}$ & $\mathrm{mg} \mathrm{kg-1}$ & 191 \\
$\mathrm{Cd}$ & $\mathrm{mg} \mathrm{kg-1}$ & 0,1 \\
$\mathrm{As}$ & $\mathrm{mg} \mathrm{kg-1}$ & $\mathrm{na}$ \\
$\mathrm{Hg}$ & $\mathrm{mg} \mathrm{kg-1}$ & $\mathrm{na}$ \\
$\mathrm{Mo}$ & $\mathrm{mg} \mathrm{kg-1}$ & $\mathrm{na}$ \\
$\mathrm{Se}$ & $\mathrm{mg} \mathrm{kg-1}$ & $\mathrm{na}$ \\
\hline & &
\end{tabular}

na = análises ainda não realizadas

Resultados de análises realizadas no Laboratório de Química Ambiental do Departamento de Ciências Exatas da ESALQIUSP.

Taxa de degradação da fração orgânica do lodo: 21 \%, obtida por ensaio de acordo com a Norma P4.230 da CETESB (1999).

Taxa de mineralização do nitrogênio: $13 \%$ aos 56 dias. 
Dados Internacionais de Catalogação na Publicação (CIP) DIVISÃO DE BIBLIOTECA E DOCUMENTAÇĀO - ESALQ/USP

\section{Paiva, Ary Vieira de}

Efeitos da aplicação de biossólido no crescimento e nutrição mineral de mudas de quatro espécies florestais nativas ultilizadas na arborização urbana / Ary Vieira de Paiva. Piracicaba, 2005

$147 \mathrm{p}$.

Tese (doutorado) - - Escola Superior de Agricultura Luiz de Queiroz, 2005.

Bibliografia.

1. Arborização 2. Biossólidos 3. Crescimento vegetal 4. Espécies florestais 5 . Metal pesado 6. Mudas 7. Plantas nativas 8 . Via urbana I. Título

CDD 634.97 


\section{SUMÁRIO}

Página

LISTA DE FIGURAS............................................................................ vi

LISTA DE TABELAS............................................................................. $\mathrm{x}$

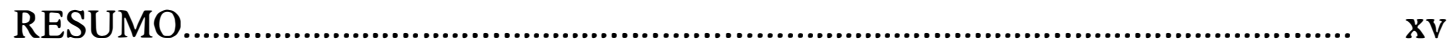

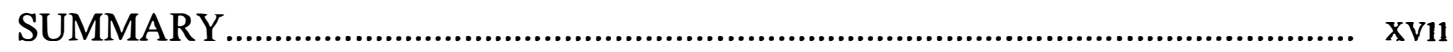

1 INTRODUÇÃO.......................................................................................... 1

2 REVISÃO DE LITERATURA..................................................................... 2

2.1 A civilização humana, as cidades e a arborização urbana........................ 2

2.2 A expansão urbana, os desequilíbrios ambientais, limites e sustentabilidade.......................................................................... 5

2.3 Tratamento de esgotos e geração de biossólido...................................... 6

2.3.1 Processos de tratamento de esgoto..................................................... 7

2.3.1.1 Tratamentos biológicos anaeróbicos................................................. 8

2.3.1.2 Tratamentos biológicos aeróbicos clássicos..................................... 8

2.3.1.3Tratamentos biológicos aeróbios precedidos de tratamento biológico anaeróbio........................................................................ 8

2.3.2 Tratamento de fase sólida em ETE................................................ 9

2.3.3 Características de biossólidos gerados em estações de tratamento

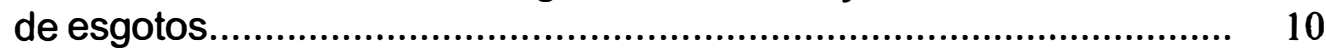

2.4 Legislação sobre biossólidos............................................................. 12

2.5 Uso agrícola, florestal e paisagístico do biosólido.................................. 13

2.6 Espécies para arborização urbana e sucessão vegetal........................... 22

2.7 Potencial de risco......................................................................... 30 
3 MATERIAL E MÉTODOS......................................................................... 35

3.1 Localização................................................................................ 35

3.2 Características da casa de vegetação................................................... 35

3.3 Características do experimento....................................................... 35

3.4 Caracterização das espécies utilizadas.............................................. 42

3.4.1 Aroeira pimenteira (Schinus terebinthifolia Raddi)............................. $\quad 42$

3.4.2 Cabreúva vermelha (Myroxylon peruiferum L. f.).............................. 43

3.4.3 Pau de viola (Cytarexyllum myrianthum Cham)................................ 43

3.4.4 Unha de vaca (Bauhinia forficata Link )......................................... 44

3.5 Metodologia de coleta , preparo e análise do material............................ 45

3.5.1 Medições de altura e diâmetro de colo, coleta de folhas, caules e

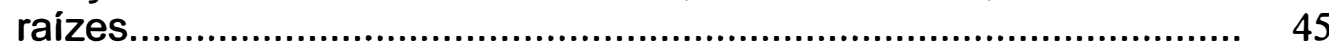

3.5.2 Parâmetros acompanhados ........................................................ 47

3.6 Análise estatística dos dados......................................................... 47

4 RESULTADOS E DISCUSSÃO................................................................... 49

4.1 Crescimento em altura.................................................................. 49

4.2 Crescimento em diâmetro de colo.................................................... 58

4.3 Produção de matéria seca ................................................................... 61

4.4 Avaliação do estado nutricional.......................................................... 69

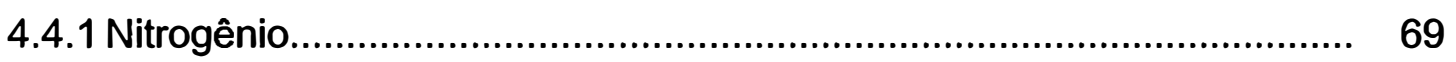

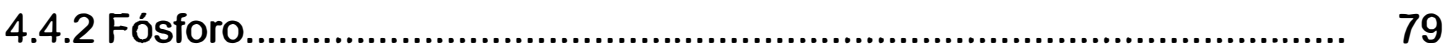

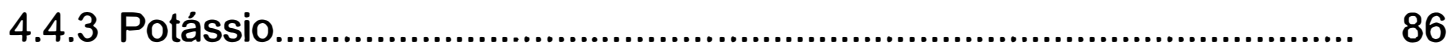

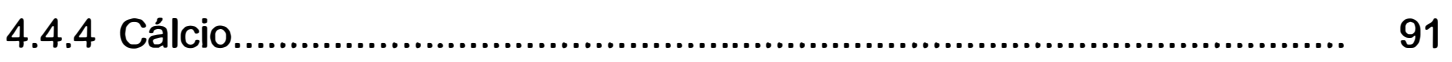

4.4.5 Magnésio.......................................................................... 95

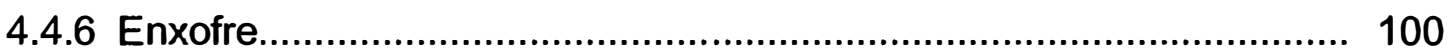

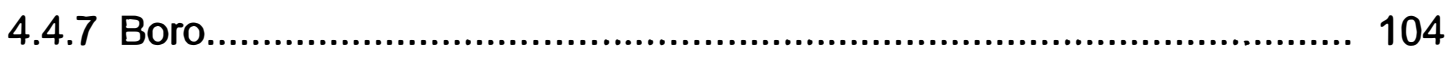

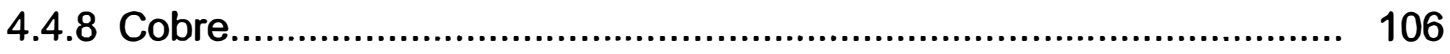


4.4.9 Manganês....................................................................... 111

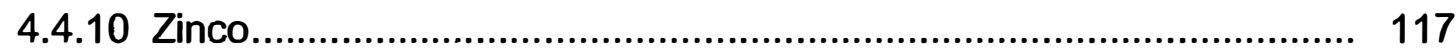

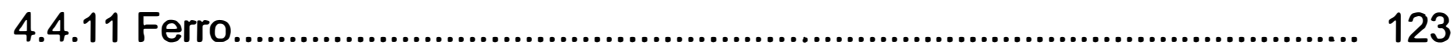

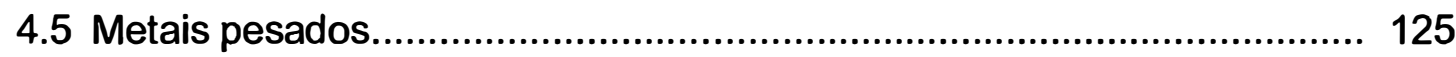

4.6 Considerações finais............................................................. 131

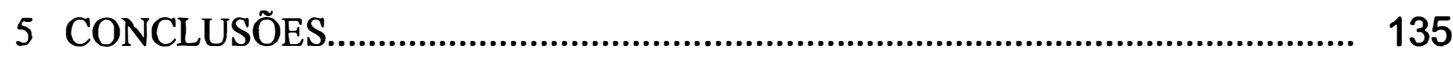

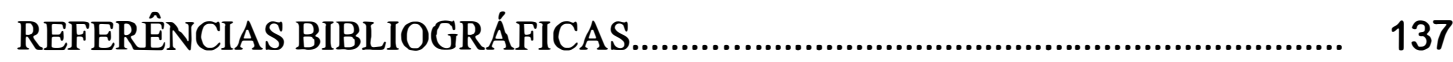




\section{LISTA DE FIGURAS}

Página

1 Experimento no interior de casa de vegetação.............................................. 36

2 Experimento aos 100 dias................................................................... 46

3 Valores médios de crescimento em altura das mudas de aroeira cultivadas em vasos com doses crescentes de biossólido e com adubação mineral aos 30,60 e 100 dias após o plantio

4 Valores médios de crescimento em altura das mudas de cabreúva cultivadas em vasos com doses crescentes de biossólido e com adubação mineral aos 30,60 e 100 dias após o plantio

5 Valores médios de crescimento em altura das mudas de pau-de-viola cultivadas em vasos com doses crescentes de biossólido e com adubação mineral aos 30,60 e 100 dias após o plantio

6 Valores médios de crescimento em altura das mudas de unha-de-vaca cultivadas em potes com doses crescentes de biossólido e com adubação mineral aos 30, 60 e 100 dias após o plantio

7 Incremento médio em altura (diferença entre a medida inicial no plantio e medida final aos 100 dias) das quatro espécies, em função das doses crescentes de biossólido e da adubação mineral.

8 Incremento médio em diâmetro de colo (diferença entre a medida inicial no plantio e medida final aos 100 dias de idade) das quatro espécies, em função das doses crescentes de biossólido e da adubação química.

9 Relação entre incremento em altura e diâmetro de caule (H/D) das quatro espécies em função das doses crescentes de biossólido e da adubação mineral 
10 Correlação linear entre doses de biossólido $\mathrm{em} \mathrm{g} \mathrm{dm}^{3}$ e produção total de matéria seca em gramas planta ${ }^{-1}$, em função das doses crescentes de biossólido e adubação mineral.

11 Relação entre a alocação de matéria seca na parte aérea e na raíz das quatro espécies em função das doses crescentes de biossólido e da adubação mineral.

12 Estoque de nitrogênio em caules das quatro espécies (g planta ${ }^{-1}$ ), em função das doses crescentes de biossólido e adubação mineral.

13 Estoque total de nitrogênio na planta, nas quatro espécies ( $g$ planta ${ }^{-1}$ ), em função das doses crescentes de biossólido e adubação mineral.......

14 Estoque de fósforo em caules das quatro espécies (g planta $\left.{ }^{-1}\right)$, em função das doses crescentes de biossólido e adubação mineral.

15 Estoque total de fósforo nas quatro espécies (g planta ${ }^{-1}$ ), em função das doses crescentes de biossólido e adubação mineral

16 Estoque de potássio nos caules das quatro espécies (g planta ${ }^{-1}$ ), em função das doses crescentes de biossólido e adubação mineral..............

17 Estoque de potássio nas raízes das quatro espécies (g planta ${ }^{-1}$ ), em função das doses crescentes de biossólido e adubo mineral.

18 Estoque total de potássio nas quatro espécies (g planta ${ }^{-1}$ ), em função das doses crescentes de biossólido e adubação mineral.

19 Estoque de cálcio nos caules das quatro espécies (g planta $\left.{ }^{-1}\right)$, em função das doses crescentes de biossólido e adubação mineral.

20 Estoque de magnésio nos caules das quatro espécies $\left(g_{\text {planta }}{ }^{-1}\right)$, em função das doses crescentes de biossólido e adubação mineral

21 Estoque total de magnésio nas quatro espécies (g planta $\left.{ }^{-1}\right)$, em função das doses crescentes de biossólido e adubação mineral.

22 Relação entre as concentrações de enxofre nas folhas e raízes nas quatro espécies, em função das doses crescentes de biossólido e adubação mineral. 
23 Estoque total de enxofre nas quatro espécies ( $g$ planta $\left.^{-1}\right)$, em função das doses crescentes de biossólido e adubação mineral.

24 Concentração de boro nas folhas das quatro espécies $\left(\mathrm{mg} \mathrm{kg}^{-1}\right)$, em função das doses crescentes de biossólido e adubação mineral

25 Concentração de boro nas raízes das quatro espécies $\left(\mathrm{mg} \mathrm{kg}^{-1}\right)$, em função das doses crescentes de biossólido e adubação mineral

26 Relação das concentrações de cobre entre folhas e raízes das quatro espécies, em função das doses crescentes de biossólido e adubação mineral.

27 Estoque de cobre nos caules das quatro espécies ( $m g$ planta ${ }^{-1}$ ), em função das doses crescentes de biossólido e adubação mineral

28 Estoque total de cobre nas quatro espécies (mg planta ${ }^{-1}$ ), em função das doses crescentes de biossólido e adubação mineral

29 Relação das concentrações de manganês entre folhas e raízes, em função das doses crescentes de biossólido e adubação mineral

30 Estoque de manganês nos caules das quatro espécies ( $\mathrm{mg} \mathrm{planta}^{-1}$ ), em função das doses crescentes de biossólido e adubação mineral......

31 Estoque total de manganês nas quatro espécies ( $\mathrm{mg} \mathrm{planta}^{-1}$ ), em função das doses crescentes de biossólido e adubação mineral.

32 Relação de estoque de zinco entre folhas e raízes das quatro espécies , em função das doses crescentes de biossólido e adubação mineral....

33 Estoque de zinco nos caules das quatro espécies ( $m g$ planta ${ }^{-1}$ ), em função das doses crescentes de biossólido e adubação mineral.

34 Estoque total de zinco nas quatro espécies ( $\mathrm{mg} \mathrm{planta}^{-1}$ ), em função das doses crescentes de biossólido e adubação mineral.

35 Estoque total de ferro nas quatro espécies (mg planta ${ }^{-1}$ ), em função das doses crescentes de biossólido e adubação mineral.

36 Concentrações médias de metais pesados $\left(\mathrm{mg} \mathrm{kg}^{-1}\right)$ e respectivos desvios padrão nas raízes das quatro espécies, em função da aplicação de $20,00 \mathrm{~g} \mathrm{dm}^{-3}$ de biossólido 
37 Concentrações médias de metais pesados $\left(\mathrm{mg} \mathrm{kg}^{-1}\right)$ e respectivos desvios padrão nas folhas das quatro espécies, em função da aplicação de $20,00 \mathrm{~g} \mathrm{dm}^{-3}$ de biossólido

38 Relação das concentrações de metais pesados entre folhas e raízes, em função da aplicação de $20,00 \mathrm{~g} \mathrm{dm}^{-3}$ de biossólido.

39 Estoque de metais nas raízes das quatro espécies, em função da aplicação de $20,00 \mathrm{~g} \mathrm{dm}^{-3}$ de biossólido.

40 Estoque de metais pesados nas folhas das quatro espécies, em função da aplicação de $20,00 \mathrm{~g} \mathrm{dm}^{-3}$ de biossólido. 


\section{LISTA DE TABELAS}

Página

1 Características gerais de três tipos de lodo de esgoto............................ 11

2 Algumas características das espécies florestais nativas do Brasil, dentro dos grupos seriais, que devem ser consideradas na escolha das espécies destinadas à arborização urbana (Budowiski,1965), adaptado por Barbosa et al.(1996)............................................................... 28

3 Tratamentos com nutrientes aplicados ao experimento......................... 37

4 Macronutrientes encontrados no solo utilizado no experimento.............. 37

5 Micronutrientes encontrados no solo utilizado no experimento................ 38

6 Parâmetros de caracterização do biossólido gerado pela ETE de Barueri

7 Parâmetros de caracterização da água utilizada para irrigação.

8 Incremento médio em altura (diferença em $\mathrm{cm}$ entre a medida inicial no plantio e medida final aos 100 dias) dentro das quatro espécies, em função das doses crescentes de biossólido e da adubação mineral........

9 Incremento médio em altura (diferença em $\mathrm{cm}$ entre a medida inicial no plantio e medida final aos 100 dias) entre as quatro espécies, em função das doses crescentes de biossólido e da adubação mineral ......

10 Resumo das ANOVAs entre tratamentos para os valores de matéria seca de folha, caule e raiz, dentro de cada espécie.

11 Produção média de matéria seca (gramas planta ${ }^{-1}$ ) da aroeira, em função das doses crescentes de biossólido e adubação mineral.

12 Produção média de matéria seca (gramas planta ${ }^{-1}$ ) da cabreúva, em função das doses crescentes de biossólido e adubação mineral. 
13 Produção média de matéria seca (gramas planta $^{-1}$ )do pau-de-viola, em função das doses crescentes de biossólido e adubação mineral.

14 Produção média de matéria seca (gramas planta ${ }^{-1}$ ) da unha-de-vaca, em função das doses crescentes de biossólido e da adubação.

15 Produção média de matéria seca (gramas planta ${ }^{-1}$ ) entre as quatro espécies, em função da aplicação de doses crescentes de biossólido e adubação mineral

16 Resumo dos resultados das ANOVAS entre tratamentos para concentrações de nitrogênio e fósforo nas folhas e raízes das quatro espécies.

17 Concentrações médias de nitrogênio $\left(\mathrm{g} \mathrm{kg}^{-1}\right)$ nas folhas e raizes das quatro espécies, em função das doses crescentes de biossólido e adubação mineral.

18 Concentrações médias de nitrogênio $\left(\mathrm{g} \mathrm{kg}^{-1}\right)$ nas folhas entre as quatro espécies, em função das doses crescentes de biossólido e adubação mineral.

19 Estoque de nitrogênio (g planta ${ }^{-1}$ ) em folhas das quatro espécies, em função das doses crescentes de biossólido e adubação mineral.

20 Estoque de nitrogênio ( $\mathrm{g}$ planta $^{-1}$ ) nas raízes das quatro espécies, em função das doses crescentes de biossólido e adubação mineral......

21 CUA - Coeficiente de Utilização Aparente de nitrogênio em porcentagem.

22 EUN- Eficiência na Utilização do nitrogênio ( $\mathrm{g}$ de matéria seca $\mathrm{g} \mathrm{de}^{-1}$ )

23 Concentrações médias de fósforo $\left(\mathrm{g} \mathrm{kg}^{-1}\right)$ nas folhas e raízes das quatro espécies, em função das doses crescentes de biossólido e adubação mineral.

24 Concentrações médias de fósforo $\left(\mathrm{g} \mathrm{kg}^{-1}\right)$ nas folhas, comparando as quatro espécies, em função das doses crescentes de biossólido e adubação mineral. 
25 Concentrações médias de fósforo $\left(\mathrm{g} \mathrm{kg}^{-1}\right)$ nas raízes, comparando as quatro espécies, em função das doses crescentes de biossólido e adubação mineral

26 Estoque de fósforo nas folhas das quatro espécies (g planta $\left.{ }^{-1}\right)$, em função das doses crescentes de biossólido e adubação mineral.............

27 Estoque de fósforo nas raízes das quatro espécies (g planta $\left.{ }^{-1}\right)$ em função das doses crescentes de biossólido e adubação mineral.............

28 CUA - Coeficiente de Utilização Aparente de fósforo em porcentagem..

29 Concentração de potássio nas folhas $\left(\mathrm{g} \mathrm{kg}^{-1}\right)$ das quatro espécies, em função das doses crescentes de biossólido e adubação mineral.

30 Concentração de potássio nas folhas $\left(\mathrm{g} \mathrm{kg}^{-1}\right)$, comparando as quatro espécies, em função das doses crescentes de biossólido e adubação mineral.

31 Concentração de potássio nas raízes $\left(\mathrm{g} \mathrm{kg}^{-1}\right)$ das quatro espécies, em função das doses crescentes de biossólido e adubação mineral.

32 Concentração de potássio nas raízes $\left(\mathrm{g} \mathrm{kg}^{-1}\right)$, comparando as quatro espécies, em função das doses crescentes de biossólido e adubação mineral.

33 Estoque de potássio nas folhas das quatro espécies ( $\left(\mathrm{g}\right.$ planta $\left.{ }^{-1}\right)$, em função das doses crescentes de biossólido e adubação mineral.

34 Concentração de cálcio nas folhas $\left(\mathrm{g} \mathrm{kg}^{-1}\right)$, comparando as quatro espécies, em função das doses crescentes de biossólido e adubação mineral.

35 Concentração de cálcio nas raízes $\left(\mathrm{g} \mathrm{kg}^{-1}\right)$, comparando as quatro espécies, em função das doses crescentes de biossólido e adubação mineral.

36 Estoque de cálcio nas folhas das quatro espécies (g planta $\left.{ }^{-1}\right)$, em função das doses crescentes de biossólido e adubação mineral.

37 Estoque de cálcio nas raízes das quatro espécies (g planta ${ }^{-1}$ ) , em função das doses crescentes de biossólido e adubação mineral. 
38 Concentrações de magnésio nas folhas $\left(\mathrm{g} \mathrm{kg}^{-1}\right)$ das quatro espécies , em função das doses crescentes de biossólido e adubação mineral

39 Concentrações de magnésio nas folhas $\left(\mathrm{g} \mathrm{kg}^{-1}\right)$, comparando as quatro espécies, em função das doses crescentes de biossólido e adubação mineral.

40 Concentrações de magnésio nas raízes $\left(\mathrm{g} \mathrm{kg}^{-1}\right)$ das quatro espécies , em função das doses crescentes de biossólido e adubação mineral......

41 Estoque de magnésio nas folhas nas quatro espécies (g planta $\left.{ }^{-1}\right)$, em função das doses crescentes de biossólido e adubação mineral

42 Estoque de magnésio nas folhas, comparando as quatro espécies ( $\mathrm{g}$ planta $^{-1}$ ), em função das doses crescentes de biossólido e adubação mineral.

43 Estoque de magnésio nas raízes nas quatro espécies (g planta ${ }^{-1}$ ), em função das doses crescentes de biossólido e adubação mineral.

44 Estoque de magnésio nas raízes, comparando as quatro espécies (g planta $^{-1}$ ), em função das doses crescentes de biossólido e adubação mineral.

45 Concentração de enxofre nas folhas $\left(\mathrm{g} \mathrm{kg}^{-1}\right)$ das quatro espécies, em função das doses crescentes de biossólido e adubação 101 mineral.

46 Concentração de enxofre nas raízes $\left(\mathrm{g} \mathrm{kg}^{-1}\right)$ das quatro espécies, em função das doses crescentes de biossólido e adubação mineral.

47 Estoque de boro nas folhas das quatro espécies ( $m g$ planta $^{-1}$ ), em função das doses crescentes de biossólido e adubação mineral

48 Estoque de boro nas raízes das quatro espécies ( $m g$ planta ${ }^{-1}$ ), em função das doses crescentes de biossólido e adubação mineral

49 Concentração de cobre nas folhas $\left(\mathrm{mg} \mathrm{kg}^{-1}\right)$ das quatro espécies, em função das doses crescentes de biossólido e adubação mineral

50 Concentração de cobre nas raízes $\left(\mathrm{mg} \mathrm{kg}^{-1}\right)$ das quatro espécies, em função das doses crescentes de biossólido e adubação mineral 
51 Estoque de cobre nas folhas das quatro espécies ( $\mathrm{mg}$ planta $\left.\mathrm{a}^{-1}\right)$, em função das doses crescentes de biossólido e adubação mineral............

52 Estoque de cobre nas raízes das quatro espécies (mg planta $\left.{ }^{-1}\right)$, em função das doses crescentes de biossólido e adubação mineral

53 Concentração de manganês nas folhas $\left(\mathrm{mg} \mathrm{kg}^{-1}\right)$ das quatro espécies, em função das doses crescentes de biossólido e adubação mineral......

54 Concentração de manganês nas folhas $\left(\mathrm{mg} \mathrm{kg}^{-1}\right)$, comparando as quatro espécies, em função das doses crescentes de biossólido e adubação mineral.

55 Concentração de manganês nas raízes $\left(\mathrm{mg} \mathrm{kg}^{-1}\right)$ das quatro espécies, em função das doses crescentes de biossólido e adubação mineral......

56 Concentração de manganês nas raízes $\left(\mathrm{mg} \mathrm{kg}^{-1}\right)$, comparando as quatro espécies, em função das doses crescentes de biossólido e adubação mineral.

57 Estoque de manganês nas folhas das quatro espécies ( $m g$ planta ${ }^{-1}$ ), em função das doses crescentes de biossólido e adubação mineral......

58 Estoque de manganês nas raízes das quatro espécies ( $\mathrm{mg}$ planta ${ }^{-1}$ ), em função das doses crescentes de biossólido e adubação mineral......

59 Concentração de zinco nas folhas $\left(\mathrm{mg} \mathrm{kg}^{-1}\right)$ das quatro espécies, em função das doses crescentes de biossólido e adubação mineral.

60 Concentração de zinco nas raízes $\left(\mathrm{mg} \mathrm{kg}^{-1}\right)$ das quatro espécies, em função das doses crescentes de biossólido e adubação mineral.

61 Estoque de zinco nas folhas das quatro espécies (mg planta ${ }^{-1}$ ) , em função das doses crescentes de biossólido e adubação mineral............

62 Estoque de zinco nas raízes das quatro espécies ( $m g$ planta ${ }^{-1}$ ) , em função das doses crescentes de biossólido e adubação mineral.

63 Estoque de zinco nas folhas, comparando as quatro espécies ( $\mathrm{mg}$ planta $^{-1}$ ), em função das doses crescentes de biossólido e adubação mineral.

64 Estoque de zinco nas raízes, comparando as quatro espécies ( $\mathrm{mg}$ planta $^{-1}$ ), em função das doses crescentes de biossólido e adubação mineral 
65 Estoque de ferro nas folhas nas quatro espécies ( $\mathrm{mg} \mathrm{planta}^{-1}$ ), em função das doses crescentes de biossólido e adubação mineral............

66 Taxa de transferência de metais pesados (\%) nas quatro espécies, em função da aplicação de $20,00 \mathrm{~g} \mathrm{dm}^{-3}$ de biossólido.................................. 


\title{
EFEITOS DA APLICAÇÃO DE BIOSSÓLIDO NO CRESCIMENTO E NUTRIÇÃO MINERAL DE MUDAS DE QUATRO ESPÉCIES FLORESTAIS NATIVAS UTILIZADAS NA ARBORIZAÇÃO URBANA
}

\author{
Autor: ARY VIEIRA DE PAIVA \\ Orientador: Prof. Dr. FÁBIO POGGIANI
}

\section{RESUMO}

O uso cada vez mais intenso da água, associado à degradação de sua qualidade nos mananciais, tem exigido das autoridades públicas investimentos no desenvolvimento de projetos educativos e de saneamento. $O$ tratamento de esgoto municipal vem crescendo ano a ano, e com isto, cresce também a geração de lodo de esgoto e a necessidade de seu tratamento e destino final ecologicamente correto. Uma das formas de destino ambientalmente adequado é a reciclagem do lodo tratado e estabilizado (biossólido), por meio de seu uso florestal. A arborização urbana tem um potencial muito grande para absorção de parte do biossólido gerado, pela sua amplitude e proximidade do local de geração. O presente trabalho teve como objetivo estudar os efeitos do uso do biossólido no crescimento, nutrição e dinâmica de metais pesados em mudas de aroeira-pimenteira (Schinus terebinthifolia Raddi), cabreúva-vermelha (Myroxylon peruiferum L. f.), pau-de- viola (Cytarexyllum myrianthum Cham) e 
unha-de-vaca (Bauhinia forficata Link), espécies nativas utilizadas na arborização urbana, cultivadas em potes no interior de casa de vegetação. $O$ estudo foi desenvolvido em um viveiro de produção de mudas localizado em Campinas, SP. O experimento foi instalado em novembro de 2003, com duração de 100 dias, em um delineamento inteiramente casualizado, com sete tratamentos (testemunha, adubação mineral, $1,25 \mathrm{~g} \mathrm{dm}^{-3}, 2,50 \mathrm{~g} \mathrm{dm}^{-3}, 5,00 \mathrm{~g}$ $\mathrm{dm}^{-3}, 10,00 \mathrm{~g} \mathrm{dm}^{-3}$ e $20,00 \mathrm{~g} \mathrm{dm}^{-3}$ de biossólido suplementados com potássio). Os resultados mostraram que a aplicação das doses crescentes do biossólido aumentou o crescimento em altura, diâmetro e produção de matéria seca, bem como o estoque de nutrientes nas quatro espécies. $O$ tratamento com $20,00 \mathrm{~g}$ $\mathrm{dm}^{-3}$ de biossólido promoveu crescimento em altura e diâmetro de colo, bem como produção de matéria seca superiores à testemunha e igual à adubação mineral nas quatro espécies. A aroeira, pau-de-viola e unha-de-vaca, espécies de início de sucessão, cresceram e produziram mais matéria seca que a cabreúva, de final de sucessão. $O$ tratamento com $20,00 \mathrm{~g} \mathrm{dm}^{-3}$ de biossólido promoveu aumento do estoque de macronutrientes ( $\mathrm{N}, \mathrm{P}, \mathrm{K}, \mathrm{Ca}, \mathrm{Mg}$ e $\mathrm{S}$ ) na biomassa das quatro espécies, bem como promoveu aumento nos estoques de micronutrientes ( $\mathrm{Cu}, \mathrm{Zn}, \mathrm{Fe}, \mathrm{Mn}$ ), com exceção do boro, que se manteve na faixa considerada de deficiência e do ferro, que não foi alterado pelos tratamentos. Os metais pesados $(\mathrm{Cr}, \mathrm{Ni}$ e $\mathrm{Pb})$ tiveram uma baixa taxa de transferência do biossólido para os tecidos das quatro espécies, mostrando ser o biossólido um insumo de baixo risco para as plantas quanto a estes fatores. Entre as espécies, a aroeira absorveu mais e a cabreúva menos metais pesados. 


\title{
EFFECTS OF SEWAGE SLUDGE (BIOSSOLIDS) APPLICATION IN THE SEEDLING GROWTH AND MINERAL NUTRITION OF NATIVE WOODY ESPECIES USED IN URBAN FORESTRY
}

\author{
Author: ARY VIEIRA DE PAIVA \\ Adviser: Prof. Dr. FÁBIO POGGIANI
}

\section{SUMMARY}

The increasing water consumption in the world, associated with general watershed degradation, is asking for public authorities more and more investments in the formulation and application of public health measures and for educational programs. The treatment of urban sewage, that increases year by year, generates the continuous growth of sludge and the need of its sanitary treatment, looking at its correct final destination. One environmentally adequate destination my be the utilization of the treated and stabilized sludge (biosolids) in forest plantations as fertilizer and soil conditioner. Also urban forestry has a good potential to absorb biosolids, considering that tree plantations are in general conducted inside town perimeter and near by wastewater treatment plants. The purpose of this experiment was to analyze the effects of different biosolids doses added to the soil on the growth, (height, diameter), nutrients concentration, nutrients stock in biomass, and also heavy metal dynamics in the seedlings of the following native tree species, usually used in urban forest plantations, that were cultivated in pots, during tree mouth: "aroeira-pimenteira" 
(Schinus terebinthifolia Raddi), "cabreúva-vermelha" (Myroxylon peruiferum L. f.), "pau-de-viola" (Cytarexyllum myrianthum Cham), "unha-devaca" (Bauhinia forficata Link). The study was conducted inside a green house located near by Campinas, SP. It was installed in November 2003, according to an entirely randomized design with seven treatments (control; mineral fertilization; $1,25 \mathrm{~g} \mathrm{dm}^{-3} ; 2,50 \mathrm{~g} \mathrm{dm}^{-3} ; 5,00 \mathrm{~g} \mathrm{dm}^{-3} ; 10,00 \mathrm{~g} \mathrm{dm}^{-3}$ and $20,00 \mathrm{~g} \mathrm{dm}^{-3}$ of biosolids, all they enriched with the same dosage of potassium, similar to the dosage applied in the mineral fertilization. Results showed that the application of increasing dosages of biosolids promoted the correspondent increasing in height, stem diameter, and dry matter production, as well the concentration and stock of macro and micronutrients in the four native tree species. The treatment with $20,00 \mathrm{~g} \mathrm{dm}^{-3}$ of biosolid promoted the best growth in height and diameter, as well as the best production of dry matter, when compared to the control. Considering the four tree species, this result was similar to the growth observed in the treatment with mineral fertilization. Aroeira, pau-viola, and unha-de-vaca, typical species of the initial succession process, grew and produced more dry biomass than cabreuva, typical specie of the final succession. Treatments with biosolids promoted the increase of macronutrients stocks ( $N, P, K, C a, M g$ and $S$ ) in all the woody species biomass, and promoted also the increase of micronutrient concentrations and stocks ( $\mathrm{Cu}, \mathrm{Zn}, \mathrm{Fe}$, and $\mathrm{Mn}$ ), except for boron and iron. Heavy metals $(\mathrm{Cr}, \mathrm{Ni}$ and $\mathrm{Pb})$ showed a low rate of transfer from biosolids to the tissues of the four species, indicating of low risk of phytotoxicity for those plants cultivated with biosolids. Considering all the species studied, aroeira absorbed significatively more heavy metals than cabreuva. 


\section{INTRODUÇÃO}

O maior contribuinte à poluição orgânica dos mananciais de água na bacia do Rio Piracicaba é o esgoto doméstico. Seu tratamento é medida indispensável à recuperação da qualidade das águas, o que vem aumentando nos últimos anos. Com o crescente tratamento de esgoto, ocorre o correspondente incremento da produção de lodo, resíduo de difícil gerenciamento e que exige estudos para sua disposição final de forma racional (reciclagem) e de maneira sanitária e ambientalmente segura. Há necessidade de se dar um destino ecologicamente adequado para o lodo de esgoto.

Desta forma, o biossólido (lodo de esgoto estabilizado) vem sendo utilizado na agricultura e no cultivo de florestas por ser fonte de matéria orgânica, de macro e micronutrientes e atuar como condicionador de solos pobres e desestruturados.

Existe um potencial muito grande de uso do biossólido na arborização urbana por questões agronômicas, ambientais e econômicas. Este último pela sua grande disponibilidade e baixo custo, estando as ETEs localizadas próximas aos locais com potencial de uso.

Nesse sentido, o condicionamento do solo urbano e nutrição adequada à arborização com espécies nativas é fator fundamental para o estabelecimento e pleno desenvolvimento das árvores. A ciclagem de nutrientes é quebrada quando se impermeabiliza a superfície do solo nas vias públicas e calçadas, onde também se promove a remoção das folhas, galhos e frutos que caem, por meio da varrição, o que leva a uma constante exportação de nutrientes, reduzindo sua disponibilidade às árvores. 
Portanto, pretende-se verificar as respostas de espécies arbóreas nativas à aplicação de diferentes doses de biossólido, visando sua utilização prática nas atividades de silvicultura urbana.

Os objetivos específicos são:

- Pesquisar e discutir a viabilidade do uso racional e seguro do biossólido na silvicultura urbana;

- Verificar o efeito do biossólido sobre o crescimento das árvores de espécies nativas;

- Avaliar as concentrações de macro, micronutrientes e metais pesados nas folhas e raízes em mudas de espécies florestais nativas, tratadas com doses crescentes de biossólido.

\section{REVISÃO DE LITERATURA}

\subsection{A civilização humana, as cidades e a arborização urbana}

Antropologistas estimam que o homem - Homo sapiens sapiens exista na presente forma entre 40.000 a 200.000 anos (Miller, 1996). Inicialmente, vivia em bandos e possuía vida nômade, sobrevivendo da exploração dos recursos naturais, encontrados dispersos pelas paisagens. A partir do advento da agricultura, surgida entre 10.000 a 15.000 anos atrás, o homem primitivo foi enraizando-se ao longo dos deltas dos rios, cultivando solos aluviais, domesticando animais, fundindo metais, criando as primeiras e pequenas cidades, passando pela revolução industrial no século XVIII e chegando aos nossos dias de grandes e conturbadas megalópoles.

O berço das primeiras cidades foi o Egito. A cidade de Kahun, construída para abrigar os trabalhadores na construção da pirâmide de Illahun 
há 3.000 anos, é considerada a mais antiga do mundo, segundo Miller (1996), mas nela não existiam árvores.

A história do paisagismo e árvores urbanas data de mais de 5.000 anos. As primeiras paisagens criadas pelo homem, diferentes da paisagem natural foram os palácios no Egito, que eram oásis criados pelas dinastias dos Faraós, com finalidades religiosas e produtivas. Na Babilônia, foram construídos os Jardins Suspensos, considerados como o primeiro uso da vegetação no espaço urbano.

$\mathrm{Na}$ Grécia, foram criadas as ágoras ou praças com a finalidade de acolher todas as divindades, onde se cultivavam choupos, plátanos, oliveiras e louros, atribuindo-se cada espécie a uma certa divindade. Em Roma existia o coliseu, o circo romano e a praça de touros, sem a existência de árvores. $\mathrm{Na}$ idade média, o clero criou os mosteiros, com quatro espaços básicos: 1) jardim de contemplação:2) ervas medicinais;3) flores e frutas e 4) conventos, com espelho d’água circular, cercado por jardins. Os senhores feudais criaram os castelos renascentistas, onde o tratamento paisagístico limitava-se ao interior dos muros que os cercavam. No período Barroco, em Versalhes, no reinado de Luiz XIV, a paisagem era tratada extrapolando-se a área central, além dos muros das cidades.

No Brasil, no Rio de Janeiro, o então vice-rei D. Luiz de Vasconcelos contratou no século XVII o mestre Valentin, como o primeiro paisagista brasileiro para fazer o passeio público em alvenaria.O passeio foi reformado em 1780 a mando de D. Pedro II. Para desenvolver o primeiro projeto de arborização urbana no país, foi contratado o paisagista Grand Jean du Montigny em 1850, mas foi Glaziov o primeiro paisagista ocidental a usar espécies nativas com flores, nas reformas do passeio público (1780).

Em muitas cidades no mundo, durante a primeira revolução industrial, os espaços públicos e vias de trânsito eram projetados sem vegetação.O Barão de Hausmann, em Paris recebeu um plano urbanístico que concebia a abertura das ruas na criação de avenidas e bulevares, quando o conceito de 
arborização de ruas era baseado em princípios meramente estéticos, com o plantio de árvores enfileiradas, marcando inicialmente o estilo de arborização como é conhecido hoje (Gonçalves, 2000). Atualmente, os aspectos psicológicos, ambientais, sociais, econômicos e políticos superam os estéticos, fazendo com que seja procurado um termo mais abrangente: a floresta urbana, que enfoca o verde urbano e suas funções ambientais em seu conjunto, e não mais a árvore isolada, individualmente, por exemplo em uma avenida. Portanto as árvores devem ser consideradas como elementos de planejamento urbano integrado e incluídAs nos planos diretores urbanos.

A arborização urbana age sobre o lado físico e mental do homem, integrando as grandes edificações à paisagem bucólica, onde a espécie se desenvolveu. Constitui-se em eficaz filtro de ar e de ruídos, fixa poeiras e gases tóxicos. Exerce ainda influência no balanço hídrico, atenua a temperatura e luminosidade, amortiza o impacto das chuvas, além de servir de abrigo e fornecer alimentos à fauna (Eletropaulo, 1995).

Em pesquisa realizada no Estado de São Paulo, o Departamento de Águas e Energia Elétrica do Estado de São Paulo - DAEE (1992) concluiu que apenas $4 \%$ dos municípios seguiram um planejamento para arborização. Também concluiu que o material proveniente da poda das árvores em $99 \%$ das cidades vai para o lixo.

A escolha das espécies a serem utilizadas na arborização urbana deve priorizar as de ocorrência nativa. As espécies arbóreas de mata atlântica são bem mais exigentes do que eucaliptos e pinus, em termos de fertilidade e de condições hídricas do solo (Gonçalves,1995).Seus estabelecimentos e desenvolvimentos dependem de um bom suprimento de nutrientes no solo.

Os ecossistemas urbanos encontram-se nos ambientes mais alterados pelo homem. Normalmente são ambientes simplificados, dilapidados de recursos naturais, degradados e extremamente agressivos à vida de inúmeras espécies animais e vegetais. Os principais fatores negativos às árvores são: a compactação e impermeabilização do solo, deficiências minerais do solo, 
poluição do solo e do ar, impactos mecânicos promovidos pelo homem e os grandes aglomerados de construções (Cestaro,1993).

Uma arborização adequada deve ser concebida de maneira planejada em função das características ambientais do sítio urbano, bem como do uso previsto das áreas, pelas pessoas que futuramente as freqüentarão, integrada ao planejamento global da cidade. Sua gestão e manejo adequados irão definir tanto sua sustentabilidade social, econômica, administrativa e ecológica.

\subsection{A expansão urbana, os desequilíbrios ambientais, limites e sustentabilidade}

O homem, ao longo de seu processo evolutivo, adquiriu capacidade de intervir e transformar a natureza, o que se denomina tecnologia, que the trouxe poder, conforto e segurança, Vanzo (2001). Mas o crescimento demográfico e desigual, concentrado em grandes centros urbanos, juntamente com o crescimento da poluição per capta, em desarmonia com os ciclos naturais vem agravando a situação da qualidade ambiental na atualidade, quando se ultrapassam largamente a capacidade de metabolização existente na biosfera, levando o homem a se atolar em várias espécies de lixo: gasoso, sólido, líquido, auditivo e visual.

Uma forma nova de se caminhar em busca de um reequilíbrio, simplificado pela harmonia entre o ambiente modificado pelo homem e o natural, é tentar aproximar a dinâmica urbana dos ciclos biogeoquímicos, por meio da reciclagem. $\mathrm{O}$ uso do biossólido na agricultura, nas florestas e no paisagismo urbano faz parte deste processo, retomando os ciclos do carbono e de vários outros minerais. 


\subsection{Tratamento de esgotos e geração de biossólido}

O lodo de esgoto é o principal subproduto do tratamento de esgotos, podendo, em princípio, conter qualquer produto utilizado na área de drenagem da estação de tratamento de esgotos onde foi produzido.

O lodo é uma mistura de sólidos orgânicos e inorgânicos, oriundo da coagulação biológica do esgoto. A sua parte mineral se origina da floculação de sólidos inorgânicos em suspensão, enquanto a parte orgânica é composta por uma fração de massa bacteriana viva e outra de sólidos voláteis suspensos, sem atividade biológica, oriundas da floculação dos sólidos orgânicos inertes do afluente e do decaimento das bactérias.

$O$ lodo de esgoto pode ser classificado em classe $A$ ou classe $B$, dependendo das características do tratamento a que for submetido (CETESBCompanhia de Tecnologia de Saneamento Ambiental, 1999). Para ser classe A, deve ter seu processo adotado para tratamento aprovado pelo Órgão de Controle Ambiental como capaz de promover uma redução adicional de patógenos, e deve atender aos seguintes limites de densidade dos

organismos especificados: a) para coliformes fecais, densidade inferior a $10^{-3}$ NMP/g ST (Numero Mais Provável por grama de sólidos totais; b) para Salmonella $\mathrm{sp}$, densidade inferior a $3 \mathrm{NMP} / 4 \mathrm{~g}$ ST (Número Mais Provável por $4 \mathrm{~g}$ de Sólidos Totais). O lodo é classificado como classe $B$ se a densidade de coliformes fecais do mesmo for inferior a $2 \times 10^{6} \mathrm{NPM} / \mathrm{g} \mathrm{ST}$.

Para o estudo relativo ao destino dos lodos gerados pelas ETEs é necessário conhecer as quantidades e características do lodo produzido em função dos sistemas de tratamento de esgoto utilizado.

A produção de esgoto doméstico no Brasil é bastante variável, ficando entre 80 e $200 \mathrm{l} / \mathrm{hab} / \mathrm{dia}$.

Em geral, o esgoto sanitário é composto de mais de 99,9\% de água, sendo o restante (inferior a $0,1 \%$ ), composto de matéria em suspensão e dissolvida (em estado coloidal ou solução), orgânica e inorgânica, bem como 
microorganismos e necessita de tratamento para ser lançado nos cursos de água e não poluí-lo. Neste sentido, foram criadas normas legais que regulamentaram a qualidade dos efluentes e a necessidade do tratamento de esgotos (Alem Sobrinho, 2001).

As legislações federal e estaduais brasileiras classificaram seus corpos de água em função de seus usos preponderantes, estabelecendo-se para cada classe de água parâmetros e padrões de qualidade, a serem mantidos nos corpos receptores. A maioria dos corpos receptores no Brasil, enquadrase na classe 2, com os seguintes parâmetros e padrões:

DBO menor ou igual a $5 \mathrm{mg} / \mathrm{l} ; \mathrm{OD}$ maior ou igual a $5 \mathrm{mg} / \mathrm{l}$; nitrogênio amoniacal menor que $3 \mathrm{mg} / \mathrm{l}$ (para $\mathrm{ph}=7$ e temp. de $20^{\circ} \mathrm{C}$ ); nitrato menor ou igual a $10 \mathrm{mg}$ $\mathrm{N} /$; fósforo menor ou igual a $0,025 \mathrm{mg} \mathrm{P} / \mathrm{l}$.

As legislações também impõem qualidade mínima a ser atendida por efluentes de qualquer fonte poluidora para lançamento em corpos de água. A resolução $n^{\circ} 20$ de 1996 do CONAMA estabelece como padrões de efluentes, dentre outros, os seguintes valores:

$\mathrm{PH}$ : entre 5 e 9; Materiais sedimentáveis: até $1 \mathrm{ml} / \mathrm{l}$;Óleos minerais: até 20mg//Óleos vegetais e gorduras animais: até $50 \mathrm{mg} /$; Materiais flutuantes: ausentes;Amônia: menor ou igual a 5 mg N//;:BBO 5 : 60 mg/l.

\subsubsection{Processos de tratamento de esgoto}

Processos existentes:

Remoção de sólidos grosseiros e areia;

Remoção dos sólidos sedimentáveis;

Remoção dos sólidos em suspensão e de matéria coloidal;

Remoção de matéria orgânica biodegradável - tratamentos biológicos. 


\subsubsection{Tratamentos biológicos anaeróbicos}

Decanto-digestores (fossas sépticas e tanques Imhoff);

Reatores UASB (reator anaeróbico de fluxo ascendente e manto de lodo);

Filtros anaeróbicos (como pós-tratamento de decanto-digestores e de reatores UASB);

Lagoas anaeróbias;

\subsubsection{Tratamentos biológicos aeróbicos clássicos}

ETE convencional com lodos ativados (com decantador primário, tanque de aeração e decantador secundário, adensador de lodo, digestor aneeróbio e desaguamento de lodo).

ETE convencional com filtro biológico percolador de alta taxa (com decantador primário, filtro biológico e cantador secundário, adensador de lodo e digestor anaeróbio e desaguamento do lodo);

ETE com lodos ativados por aeração prolongada, sem decantador primário;

ETE com lodos ativados de alta taxa, sem decantador primário e sem digestor de lodo, tanque de aeração com oxigênio puro ou através de poço profundo tipo deep shaft.

ETE com lagoas aeradas aeróbias seguidas de lagoas de decantação.

\subsubsection{Tratamentos biológicos aeróbios precedidos de tratamento biológico anaeróbio}

ETE com reator UASB seguido de lodos ativados;

ETE com reator UASB seguido de filtro biológico de alta taxa;

ETE com reator UASB seguido de filtro aerado submerso, ou biodisco (sem nitrificação); 
ETE com reator UASB e biofiltro aerado submerso, com material de enchimento granular, sem nitrificação e sem decantador secundário.

ETE com reator UASB seguido de lagoa aerada aeróbia e de lagoas de decantação;

O grande problema de ETEs nas regiões metropolitanas e de cidades médias brasileiras é o destino a ser dado ao lodo produzido. A quantidade de lodo produzida é em função do tipo de estabilização utilizado (biológica aeróbia, anaeróbia ou química) e do tipo de equipamento de desaguamento utilizado, podendo considerar as seguintes faixas de valores de teor de sólidos:

Os lodos digeridos anaerobiamente, são desidratados por quatro processos, sendo um por filtro prensa de placas produzindo um lodo com 30 a $40 \%$ de sólidos, por filtro de prensa de esteiras, produzindo um lodo com 15 a $25 \%$ de sólidos, por centrífugas com 25 a $30 \%$ de sólido e através de leitos de secagem produzindo lodo com 20 a $30 \%$ de sólidos.

Os lodos digeridos aerobiamente, são desidratados por filtro de prensa, produzindo 25 a $35 \%$ de sólidos, filtro de prensa de esteiras, produzindo 13 a $18 \%$ de sólidos e centrífugas, produzindo lodo com 20 a $25 \%$ de sólidos.

\subsubsection{Tratamento de fase sólida em ETE}

O aumento da produção de lodo vem crescendo a cada dia no Brasil, devido à expansão das estações de tratamento de esgoto e a necessidade de atendimento à legislação ambiental.

Nos Estados Unidos, a produção de lodo em 2000 foi de 13 milhões de toneladas. Para a região metropolitana de São Paulo, a projeção para 2005 segundo o Plano Diretor de Lodos da SABESP (1998) é de 785 t/dia (base seca). 
A fase sólida de tratamento é responsável, numa ETE, por aproximadamente $40 \%$ dos custos de implantação, $50 \%$ dos custos de operação e por $90 \%$ dos problemas operacionais, segundo Miki et al. (2001).

Os tipos de sólidos podem ser constituídos por material gradeado, areia, escuma e lodo.

Os tipos de adensamento do lodo (remoção de água) mais comuns são: por gravidade, flotação com ar dissolvido, centrífuga, adensador de esteira. A estabilização do lodo tem por objetivos reduzir a quantidade de patógenos, eliminar os maus odores, inibir, reduzir ou eliminar o potencial de putrefação. Os meios para atingir a estabilização são a redução biológica do conteúdo de sólidos voláteis, oxidação química da matéria orgânica, adição de produtos químicos no lodo de modo a impedir a sobrevivência de microorganismos e a aplicação de calor para secar, desinfetar ou esterilizar o lodo.

As tecnologias mais empregadas na estabilização são a estabilização por cal, digestão anaeróbia, digestão aeróbia, compostagem.

Dentre elas, a digestão anaeróbia é o processo mais comum para a estabilização do lodo (Miki et al., 2001).

Com o potencial de disposição final do lodo como fertilizante, as estações de tratamento deverão dispor de processos eficientes e confiáveis de estabilização. A higienização do lodo biodigerido com cal tem se mostrado método eficaz e de baixo custo para remoção de patógenos. A compostagem também tem se mostrado eficiente, segundo Fernandes (2000).

\subsubsection{Características de biossólidos gerados em estações de tratamento de esgotos}

A predominância de atividades no meio urbano, além do esgoto doméstico, determina a composição do esgoto.O biossólido é o lodo de esgoto estabilizado, que é produzido através de vários processos de 
biotransformação, proporcionando odor menos ofensivo e menor concentração de microorganismos.

As características do lodo de esgoto dependem do tipo de esgoto, do processo e grau de tratamento do esgoto, do tipo de lodo, do processo de tratamento do lodo, etc.

De um modo geral, os fatores de risco devido aos lodos podem ser divididos, segundo Tsutiya (2001) em:

Temporários: odor, salinização, poluição das águas, organismos patogênicos;

A longo prazo: metais pesados, contaminantes orgânicos.

Características físicas:

O lodo de esgoto é constituído por água e sólido granuloso, flocoso e coloidal.

Tabela 1. Características gerais de três tipos de lodo de esgoto

\begin{tabular}{|c|c|c|c|}
\hline PARÁMETROS & $\begin{array}{l}\text { LODO } \\
\text { PRIMÁRIO }\end{array}$ & $\begin{array}{l}\text { LODO } \\
\text { SECUNDÁRIO }\end{array}$ & $\begin{array}{l}\text { LODO } \\
\text { DESIDRATADO }\end{array}$ \\
\hline SÓLIDOS SECOS & $2-6 \%$ & $0.5-2 \%$ & $15-35 \%$ \\
\hline SÓLIDOS VOLÁTEIS & $60-80 \%$ & $50-70 \%$ & $30-60 \%$ \\
\hline PESO ESPECÍFICO LODO & 1.02 & 1.05 & 1.1 \\
\hline $\begin{array}{l}\text { PESO ESPECÍFICO SÓLIDOS } \\
\text { DO LODO }\end{array}$ & 1.4 & 1.25 & $1.2-1.4$ \\
\hline $\begin{array}{l}\text { FORÇA DE CISALTAMENTO } \\
\left(\mathrm{KN} / \mathrm{m}^{2}\right)\end{array}$ & $<5$ & $<2$ & $<20$ \\
\hline $\begin{array}{l}\text { ENERGIA CONTIDA NO } \\
\text { LODO (MJ/kgSV) }\end{array}$ & 1022 & 1220 & 2530 \\
\hline $\begin{array}{l}\text { TAMANHO DA PARTÍCULA } \\
(90 \%)\end{array}$ & $<200 \mu \mathrm{m}$ & $<100 \mu \mathrm{m}$ & $<100 \mu \mathrm{m}$ \\
\hline
\end{tabular}

A composição química média do lodo de esgoto típico é de $40 \%$ de matéria orgânica, $4 \%$ de nitrogênio, $2 \%$ de fósforo e $0,4 \%$ de potássio, segundo USDA (1980), mas é bastante variável, segundo características do efluente e suas formas de tratamento. 
As características químicas específicas, a partir de amostras coletadas do lote de lodo utilizado no experimento, estão descritas em materiais e métodos.

\subsection{Legislação sobre biossólidos}

Uma grande preocupação no uso do lodo de esgoto para fins agrícolas, florestais e paisagísticos é a ausência de normas e leis que balizem este uso, na perspectiva da preservação do equilíbrio dos ecossistemas envolvidos, bem como da saúde pública, principalmente no que diz respeito aos metais pesados e patógenos presentes no biossólido.

$\mathrm{Na}$ medida em que os trabalhos científicos foram sendo publicados no mundo, vários países foram normatizando seu uso tendo como base os seus resultados.

$\mathrm{Na}$ Europa, o Conselho Diretor da Comunidade Comum Européia definiu critérios para o uso de biossólido na agricultura, fixando uma quantidade máxima, abaixo da qual os estados membros podem definir suas legislações específicas. Dentre estes países, Carvalho et al. (2001) destaca o caso da Alemanha, que segundo ele é uma das mais rigorosas, que vai além de restringir valores máximos para metais pesados também o fazendo para poluentes orgânicos.

O projeto da legislação brasileira atualmente em discussão no CONAMA, tanto quanto as normas da CETESB para o Estado de São Paulo, baseiam-se principalmente na legislação americana.

Para o Estado de São Paulo, existe a Norma P 4.230 CETESB (1999), que dispõe critérios técnicos para aplicação de lodos de sistemas de tratamento biológico em áreas agrícolas. Esta norma estabelece concentrações limites de metais pesados no biossólido, bem como quantidades máximas de metais pesados que podem ser aplicados nos solos agrícolas, através deles, por hectare ano. Estipula ainda as quantidades máximas acumuladas de metais pesados que podem ser aplicadas através de 
biossólidos numa determinada área. Define também que a taxa de aplicação em função do nitrogênio disponivel não deverá ultrapassar o quociente entre a quantidade de nitrogênio recomendada para a cultura em $\mathrm{kg} / \mathrm{ha}$ e o teor de nitrogênio disponível no lodo. Classifica o lodo em várias classes quanto aos processos de redução de patógenos, não aceitando para uso em áreas agrícolas o lodo que não atender, no mínimo, o estipulado para a classe $B$.

Os critérios de localização da aplicação, critérios para estocagem, responsabilidades operacionais quanto a aplicação e monitoramento, bem como as responsabilidades do gerador são definidos nas normas.

No Brasil, o registro e a fiscalização dos fertilizantes, corretivos e condicionadores do solo, inclusive no tocante a saúde pública e proteção ao meio ambiente, nos termos do Decreto Lei 82.955/82 compete ao Ministério da Agricultura, ficando claro um conflito entre a legislação federal e as normas da CETESB. Esta legislação federal é omissa quanto ao uso de biossólido tanto pelo aspecto da presença de metais pesados quanto da de agentes patogênicos e já passa por um processo de revisão, visando não apenas a atender as exigências internas, mas também às internacionais, que são muito rigorosas quanto a qualidade dos produtos agrícolas.

\subsection{Uso agrícola, florestal e paisagístico do biossólido}

Para seu estabelecimento e desenvolvimento, as plantas necessitam de 16 elementos químicos considerados essenciais e de outros que têm efeitos positivos sobre o desenvolvimento vegetal.

Os elementos $\mathrm{N}, \mathrm{P}, \mathrm{K}, \mathrm{Ca}, \mathrm{Mg}$ e $\mathrm{S}$, são denominados macronutrientes por aparecerem na composição dos tecidos das plantas em maior quantidade, e preferencialmente são retirados do solo.

Os elementos $\mathrm{Cu}, \mathrm{Fe}, \mathrm{Mn}, \mathrm{Zn}, \mathrm{Mo}, \mathrm{B}$ e $\mathrm{Cl}$ são denominados micronutrientes por aparecerem nos tecidos das plantas em menores quantidades, também são preferencialmente retirados do solo. O Co e Ni já 
podem ser considerados essenciais atualmente, segundo Melo et al. (2001). O Co por participar da composição de biomoléculas essenciais como a cobalamina e as enzimas desidratases, fosforilases, mutases e transferases. $O$ $\mathrm{Ni}$, participa do sítio ativo da enzima urease. $\mathrm{O} \mathrm{Si}, \circ \mathrm{V}$ e $\circ \mathrm{Cd}$ são considerados elementos benéficos ao desenvolvimento das plantas.

O biossólido contém todos os nutrientes essenciais e benéficos para 0 desenvolvimento dos vegetais, segundo Melo et al. (2001). Assim sendo, sua composição chama a atenção para o potencial para uso agrícola, florestal e paisagístico, como condicionador ou como substituto de parte dos fertilizantes minerais solúveis atualmente utilizados.

Entre as diversas alternativas existentes para disposição do lodo de esgoto, as aplicações agrícola, florestal e paisagística apresentam-se como as mais convenientes, uma vez ser rico em nutrientes e matéria orgânica. Contudo, este produto pode apresentar elevados teores de metais pesados e organismos patogênicos ao homem, determinando a necessidade de monitoramento para acompanhamento de sua dinâmica no meio ambiente.

O desconhecimento dos efeitos de seu uso em ecossistemas tropicais é uma das questões mais importantes a ser superada para o seu uso seguro.

O lodo de esgoto, para seu uso agrícola seguro, deve ser estabilizado por processos biológicos, recebendo então a denominação de "biossólido" pela WEF (Water Environment Federation). Sua estabilização tem como finalidades a redução de seus microorganismos patogênicos e inibição do potencial de putrefação e produção de odores.

Também se faz necessária sua regulamentação, de modo a balizar as condições e restrições à sua aplicação com relação à preservação do meio ambiente e da qualidade de vida de seus habitantes (Tsutya, 2000).

O mesmo autor também afirma que a experiência mundial tem mostrado que, quando os biossólidos são aplicados na agricultura obedecendo-se às diretrizes fixadas para seu uso, não são constatados efeitos adversos à saúde 
humana ou ao meio ambiente. As restrições para uso agrícola referem-se a culturas que são servidas "in natura" aos seres humanos.

O lodo de esgoto é um resíduo que altera as propriedades físicas do solo, melhorando sua densidade, sua porosidade e sua capacidade de retenção de água,(Melo et al., 2001). Altera as características químicas do solo, melhorando seu nível de fertilidade, elevando o $\mathrm{pH}$, diminuindo o teor de Al trocável, aumentando sua CTC. Também promove o crescimento de organismos do solo, os quais são fundamentais para a ciclagem de nutrientes.

A vantagem do biossólido em relação aos fertilizantes minerais, consiste em proporcionar de forma gradual e contínua a liberação dos nutrientes para o solo e para o sistema radicular das plantas. Mas devido à observação de alguns desequilíbrios nutricionais, é importante que se realize o estudo contínuo da ciclagem de vários elementos químicos (nutrientes e metais pesados) para acompanhar sua dinâmica no ecossistema, (Poggiani et al., 2000).

Estudando o efeito do biossólido na fertilidade do solo e nutrição das árvores, Gonçalves et al. (2000)b estima que a dose ideal de biossólido técnica e economicamente viável para plantações de eucalipto deverá ficar entre 10 a $20 \mathrm{Mg} \mathrm{ha}^{-1}$, aplicada em intervalos de 7 anos. A aplicação deve ser feita em faixas sobre as linhas de plantio ou a lanço em área total, antes do plantio. As perdas de nutrientes por lixiviação e erosão são baixas, por serem culturas permanentes e apresentarem sistemas radiculares muito desenvolvidos horizontal e verticalmente. A suplementação do biossólido com fertilizante fosfatado pode se tornar necessária para plantações de eucalipto, pela sua alta demanda inicial por este nutriente. Se os teores de $\mathrm{K}$ forem baixos no solo, a suplementação com fertilizante mineral potássico é fundamental, pois a concentração deste nutriente no biossólido é muito baixa.

No Distrito da Grande Chicago nos Estados Unidos, Hayward (1997) relata que o biossólido tem sido usado na construção de campos de golfe em substituição ao solo (620 t/ha) e para fertilização de gramados. 
No Distrito Federal Brasileiro, segundo Luduvice (2000), a CAESB/EMATER não recomendam seu uso em plantações de hortaliças, devendo ficar restrito ao plantio de árvores frutíferas, forrageiras, café, milho, plantas ornamentais e outros produtos agrícolas que não tenham consumo in natura. Embora não recomendem sua aplicação em gramados, pelo risco de contaminação de crianças que os freqüentam, reconhecem que muitas agremiações esportivas em Brasília o estão utilizando para cobertura do gramado de campo de futebol, fazendo imediatamente uma irrigação e cobertura com terra, ficando ainda interditado por um tempo. A CAESB faz a distribuição gratuita do biossólido à população.

Corroborando as orientações da CAESB, Tsutya (2000) afirma que não se deve usar o biossólido em culturas cujos produtos tenham contato com o mesmo, que venham a ser consumidos in natura. Recomenda o uso em culturas de cereais, fruticultura, reflorestamento e recuperação de áreas degradadas.

As aplicações florestais no Brasil e no Estado de São Paulo apontam para um grande potencial de uso do biossólido. No Brasil, Gonçalves et al. (2000)b estimou que existiam cerca de cinco milhões de hectares reflorestados com pinus (35\%) e eucaliptos (65\%) e no Estado de São Paulo 790.000 ha (70 \% eucaliptos e $30 \%$ pinus), sendo a grande maioria cultivados em solos de baixa fertilidade natural. Vários trabalhos de pesquisa nesta linha, vêm sendo desenvolvidos na Estação experimental de Itatinga, pelos docentes da ESALQ/USP, patrocinadas pela SABESP, FAPESP e FINEP, em cultura comercial de Eucalyptus grandis Hill Ex Maiden, tendo entre os principais subprojetos: diagnóstico do potencial e avaliação econômica do uso de biossólido em plantações florestais; caracterização química de biossólido; efeito do biossólido na fertilidade do solo e crescimento das árvores; monitoramento da ciclagem de nutrientes na biomassa florestal, vegetação do sub-bosque e na água dos mananciais; movimentação dos metais pesados no solo dos talhões florestais; avaliação da decomposição da carga orgânica de biossólido no solo 
de plantações florestais e efeito de biossólido aplicado nos talhões florestais, sobre o sub-bosque e a cadeia alimentar .

A SABESP, gerenciadora da ETE de Franca-SP, produz o SAESFÉRTIL, sendo a primeira estação de tratamento de esgotos do Brasil que também é uma indústria de insumos agrícolas, registrada no Ministério da Agricultura. Recomenda o uso de seu produto, excetuando-se aquelas culturas cuja parte colhida toque o solo, tais como melão, abóbora, pepino e hortaliças, a menos que a aplicação tenha sido feita há pelo menos 14 meses antes do plantio; nas culturas de alimentos cuja parte comestível fique abaixo da superfície do solo, tais como batatas, cenouras, rabanetes, exceto se a aplicação de biossólido tiver sido feita 38 meses antes do plantio, e também não recomenda aplicação em pastagens para uso pelo gado em período inferior a um ano após a aplicação. Além disso, o sítio de aplicação deve observar as seguintes localizações: estar distante pelo menos 100 metros de núcleos habitacionais, não aplicar em áreas de preservação permanente e estar distante 15 metros do limite da propriedade e de vias de domínio público. Ainda informam as formas mais adequadas para a aquisição, transporte, armazenagem e técnicas de aplicação.

A maioria dos trabalhos de pesquisa realizados sobre a aplicação de biossólido é dirigida a espécies herbáceas e arbustivas, ficando as espécies arbóreas com uma porcentagem menor de trabalhos. As espécies arbóreas mais estudadas são as de clima temperado, existindo um grande campo para pesquisas de espécies florestais tropicais.

$\mathrm{Na}$ grande maioria dos trabalhos, as gramíneas apresentaram respostas positivas à aplicação de biossólido, principalmente em sítios mais pobres em nutrientes. Em alguns experimentos a ação fitotóxica de metais pesados foi relatada como fator limitante ao desenvolvimento de gramíneas (Deschamps et al.,1996). Também afirma que a aplicação contribuiu para melhor estabelecimento de árvores, sendo que aumentaram o crescimento em altura e em diâmetro nos tratamentos com lodo. 
Estudos sobre os efeitos de biossólido no crescimento de arbustos em casa de vegetação desenvolvidos por Tunison et al. (1982) citados por Deschamps et al. (1996) demonstraram respostas positivas à sua aplicação. Também utilizando lodo por 20 anos, objetivando aumentar a produtividade de alguns solos de floresta em Washington (USA), Henry et al.(1993)a observaram que o tratamento com lodo proporcionou uma resposta em crescimento maior que adubos químicos, como permitiu também o aumento da produtividade do sítio.

O uso de biossólido na recuperação de solos degradados, tem apresentado resultados muito promissores, afirma llhenfeld et al. (1999), devido principalmente ao fato de que os solos degradados são ácidos, na grande maioria, o que é facilmente corrigido no caso do uso do lodo calado, devido a alta PRNT da cal; fornecimento de nitrogênio e fósforo nas formas orgânicas, com efeito residual mais prolongado, se comparado ao uso de fertilizantes sintéticos e pela incorporação de matéria orgânica, capaz de condicionar os solos degradados, influenciando positivamente na sua estruturação, o que facilita a penetração de água e das raizes. De maneira geral, os resultados de seu trabalho de pesquisa apresentaram elevação do $\mathrm{PH}$ nos tratamentos com lodo, proporcionais ao aumento da dosagem e a CTC natural do solo, evidentemente elevando os teores de cálcio e magnésio, CTC e V\%, com redução nos teores de potássio.

Os sítios florestais são beneficiados basicamente de duas maneiras pela adição de biossólido: pela imediata resposta em crescimento das espécies e, a longo prazo, pelo aumento a produtividade do sítio. Todavia, Henry et al.(1993)b alerta que para que seja bem utilizada e aceita, se faz necessário sua regulamentação por agências e devida campanha educativa de massa. Também os mesmos autores afirmam que a despeito do grande potencial para uso em áreas florestais, pode haver conflitos quanto aos usos múltiplos de áreas florestais, quando também destinadas ao lazer e para a vida selvagem, pois algumas características físicas e químicas dos biossólido 
são muitas vezes inconvenientes (odor, cor, microorganismos, metais pesados, etc). Apresenta ainda os riscos ambientais e para a saúde pública, a saber: a- presença de metais pesados; b- patógenos; c- produtos orgânicos; dnitratos. Os patógenos e metais pesados devem ser monitorados em sua dinâmica na superfície do solo, lençóis freáticos, na vegetação e cadeia alimentar. Na aplicação florestal os riscos são minimizados quando comparado à aplicação agrícola. O nitrogênio é considerado como fator limitante à aplicação do biossólido, não devendo ultrapassar $47 \mathrm{t} \mathrm{ha}^{-1}$ devido ao risco de contaminação do lençol freático pela lixiviação dos nitratos, segundo o mesmo autor.

Os efeitos da aplicação de lodo de esgoto a partir de chorume em dois solos florestais em Douglas-Fir, oeste de Washington, foram descritos por Rikerk (1981), quando se aplicou $1.080 \mathrm{t} \mathrm{ha}^{-1}$. Observou que o nível de nitrato no solo drenado incrementou em duas vezes, mas diminuiu a base de 10 ppm de $\mathbf{N}$ em três anos. A renovação ou limpeza pela lixiviação do solo é boa, especialmente sob solos cobertos por florestas, todavia o lençol freático poderá ser afetado.

Wen et al. (1997) estudando a disponibilidade de pọássio às plantas, aplicado através de biossólido oriundo de 4 formas de tratamentos diferentes, observou que a disponibilidade do nutriente às plantas foi similar à administrada via fertilização mineral.

Estudando os efeitos da fertilização de três espécies florestais no norte da Ilha de Vancouver, Weetman et al. (1993) aplicaram fertilizantes convencionais à base de nitrato de amônio (225 kg N ha-1), superfosfato triplo ( $75 \mathrm{~kg} \mathrm{P} \mathrm{ha}^{-1}$ ) e lodo de esgoto aplicado com base no fornecimento de $500 \mathrm{~kg}$ ha ${ }^{-1}$ de $\mathrm{N}$ e $133 \mathrm{~kg} \mathrm{ha}^{-1}$ de $\mathrm{P}$. Observaram que o lodo de esgoto promoveu melhor desenvolvimento que a fertilização convencional, sem induzir a clorose por deficiência de enxofre provocada pela última. A longo prazo, os tratamentos com lodo mostraram melhor suprimento de nutrientes que a fertilização convencional. 
Estudando os efeitos em longo prazo de várias aplicações de biossólido (500 $\mathrm{t}$ ha ${ }^{-1}$ ) em solos florestais, Harrison et al. (1993) concluíram que o fornecimento de nutrientes à zona radicular se estendeu a 15 anos após a aplicação, apontando par uma liberação lenta e gradual dos nutrientes, diminuindo assim as perdas por lixiviação e fornecendo nutrientes às árvores próximo a sua demanda em seu processo de desenvolvimento. Os efeitos sobre as propriedades físicas foram percebidos na faixa de $0-27 \mathrm{~cm}$ abaixo da qual não se observaram modificações significativas. Foi notável a maior quantidade de material umificado e menos raízes finas nos solos tratados. $\mathrm{O}$ solo não tratado (testemunha) exibiu muito mais raízes finas e grande porcentagem de matéria orgânica oriunda do folhedo. Os efeitos nas concentrações de nutrientes foram claros, ficando a concentração de C o dobro nos solos tratados quando comparados à testemunha. $\mathrm{O} N$ total aumentou em mais de três vezes, a relação $\mathrm{C} / \mathrm{N}$ foi reduzida de 20:1 para $12: 1$, indicando uma relativa suficiência de $n$ no solo. $O$ incremento de $P$ no solo foi muito grande, aproximadamente sete vezes mais nos solos tratados. As concentrações de $\mathrm{K}$ não apresentaram diferenças significativas. Parte do $\mathrm{C}$ e $\mathbf{N}$ foram perdidos, provavelmente pela oxidação da matéria orgânica, nitrificação e lixiviação do $\mathrm{N}$. O PH do solo abaixou, provavelmente pela oxidação da matéria orgânica e liberação de $\mathrm{h}^{+}$para o solo e a CTC aumentou de 18 para 30 mmolc $\mathrm{kg}^{-1}$, o que demonstrou a importante contribuição do biossólido para o aumento da CTC. O fósforo total adicionado foi retido na superfície do solo. Grande quantidade do $\mathrm{Ca}, \mathrm{Mg}$ e $\mathrm{K}$ foram lixiviados do horizonte do solo.

A aplicação do biossólido em cultivos homogêneos de Eucaliptus grandis Hill ex Maiden alterou significativamente o estado nutricional dos mesmos e contribuiu para maior reciclagem biogeoquímica dos nutrientes dentro do ecossistema, segundo Guedes (2000).

Estudando os efeitos de doses crescentes de lodo de esgoto em algodão no interior de casa de vegetação, equivalentes a $0,60,100,200,250$ 
e $300 \mathrm{~kg} \mathrm{~N} \mathrm{ha}^{-1}$, Pedrosa et al. (2003) verificaram efeitos significativos pelo teste $\mathrm{F}$ ao nivel de $1 \%$ de probabilidade das doses sobre as variáveis estudadas. Verificaram também, por análise de regressão, aumento linear das variáveis peso do algodão em caroço, peso de pluma, fitomassa da parte aérea, fitomassa total e de relação fitomassa da parte aérea/fitomassa da raiz, estimando as doses de maior resposta de biossólido equivalentes a 441 e 231 $\mathrm{kg} \mathrm{N} \mathrm{ha}^{-1}$ para o número de capulhos por planta e fitomassa de raiz.

Avaliando os efeitos de lodo de esgoto como fonte de $\mathrm{N}$ no crescimento do feijoeiro em casa de vegetação, Vieira et al.(2004) observaram que a dose de $29,6 \mathrm{t} \mathrm{ha}^{-1}$ forneceu a quantidade de $\mathrm{N}$ recomendada e que a aplicação de fertilizante nitrogenado no feijoeiro pode ser substituída por quantidade adequada de lodo de esgoto.

O estudo da viabilidade de uso de biossólido como componente do substrato para produção de mudas de eucalipto foi desenvolvido por Trigueiro et al. (2003), cujos resultados revelaram que mudas de eucalipto desenvolvidas em substrato contendo biossólido e casca de arroz carbonizada em partes iguais apresentaram resultados semelhantes ao substrato comercial (Multiplant), concluindo-se que o uso desse resíduo para produção de mudas é viável e promissor.

Os resultados de estudos sobre o metabolismo microbiano em solo argiloso tratado com biossólido oriundo da ETE de Franca, desenvolvidos por Lopes (2002), sugerem que a aplicação provoca um distúrbio na fisiologia da microbiota do solo e que aplicações sucessivas de altas doses de biossólido podem ocasionar alterações significativas na capacidade metabólica dos solos, o que indica cautela quanto ao uso sobre este aspecto.

Romanov (1997), estudando as reações de mudas florestais à aplicação de lodo no solo na Rússia, observou não haver uma correspondência na aplicação de lodo e a transferência do seu conteúdo em metais pesados às plantas. Observou também que o conteúdo de metais pesados nas plantas foi maior nas raizes finas do que nos galhos e folhas. 
Estudando os efeitos de lodo de esgoto no desenvolvimento e bioacumulação de metais pesados em doses equivalentes a $0,40,80,120 \mathrm{e}$ $200 \mathrm{~kg}$ de $\mathrm{N}$ disponivel por hectare, Labreque et. al. (1995) observaram que as plantas tratadas com as maiores doses de biossólido apresentaram os maiores crescimentos, concluindo que o lodo drenado e peletizado é um bom fertilizante. A taxa de transferência de metais pesados do biossólido para as plantas não variou entre as espécies. Entre os metais, $\mathrm{Cd}$ e $\mathrm{Zn}$ foram absorvidos em maiores quantidades que o $\mathrm{Ni}, \mathrm{Hg}$, $\mathrm{Cu}$ e $\mathrm{Pg}$.

Battistel et al. (1993), estudando os efeitos da aplicação de composto orgânico contendo lodo de esgoto, no desenvolvimento de árvores florestais em vasos, concluíram que altas concentrações de composto reduziram o desenvolvimento das espécies mais delicadas.

Stone \& Powers (1989) constataram que a aplicação de lodo de esgoto aumentou o desenvolvimento e reduziu as infecções por Fusarium em mudas de Loblolly Pine.

Gouin \& Walker (1977), pesquisando as respostas de mudas de espécies florestais decíduas, cultivadas em solo tratado com lodo de esgoto peneirado $\mathrm{e}$ não peneirado, nas doses de $0,112,224$ e $448 \mathrm{t} \mathrm{ha}^{-1}$, observaram que a maior resposta em crescimento foi promovida pela dose de $224 \mathrm{tha}^{-1}$ de composto de lodo peneirado.

Bonnet et al. (2002), estudando os efeitos de substratos na produção de mudas de E. viminalis, Schinus terebinthifolius e mimosa scabrella, apontaram como mais adequada a porcentagem de participação do biossólido entre 30 e $60 \%$ da mistura do substrato.

\subsection{Espécies para arborização urbana e sucessão vegetal}

A escolha das espécies arbóreas para plantio deve levar em consideração vários aspectos, tais como suas características ecológicas e a finalidade a que se destinam, as características do sítio onde serão plantadas, 
as limitações de manejo futuro, as interações com as populações destes sítios e a sustentabilidade destas intervenções.

$\mathrm{Na}$ arborização das cidades, as árvores se destinam a tornar o ambiente urbano menos agressivo aos seus habitantes, na tentativa de integrar as estruturas urbanas com a paisagem campestre. Dentre os objetivos esperados estão os efeitos positivos no microclima urbano, tais como: a) efeito tampão sobre a temperatura e umidade relativa do ar, minimizando variações bruscas destes fatores, melhorando assim o conforto ambiental para seus habitantes; $b$ ) minimização dos impactos dos ventos sobre as cidades, através do aumento da rugosidade do meio urbano com conseqüente aumento do atrito superficial e mesmo servindo como barreiras quebra ventos; c) aumento da refletância da luz solar que incide nas cidades, reduzindo a temperatura e o efeito dos comprimentos de onda indesejáveis sobre a pele humana, contribuindo para melhorar a saúde pública; d) redução dos poluentes no ar (material particulado, $\mathrm{CO}_{\mathrm{x}}, \mathrm{NO}_{\mathrm{x}}, \mathrm{SO}_{\mathrm{x}}$ ) através da remoção, armazenamento, metabolização e transferência; e) redução dos efeitos da poluição sonora nas residências e na população. Um efeito muito importante, porém de difícil mensuração, diz respeito à satisfação psicológica humana ao viver em um ambiente cercado de vegetação e de plantas floridas.

Outro aspecto muito importante, que se soma aos benefícios promovidos ao ambiente urbano, diz respeito à diversidade das espécies vegetais e animais nas cidades. Quanto maior a diversidade das espécies em um sítio, maior a sustentabilidade ecológica do mesmo. Quanto maior a diversidade das espécies encontradas em um ecossistema, maior a sua capacidade de absorção dos impactos ambientais negativos como a poluição, adversidades climáticas, impactos inerentes à dinâmica urbana, pragas e doenças, etc.

As cidades e seus arredores apresentam maior número de espécies de seres vivos que as paisagens agricolas ou reflorestadas, perdendo talvez apenas para as áreas naturais (Cestaro, 1985). 
Ainda segundo o mesmo autor, para se maximizar os efeitos benéficos e mesmo explora-los de maneira correta, há de se avaliar as caracteristicas de cada espécie e se enumerar as funções esperadas das mesmas no ambiente urbano, através de pesquisas científicas, cujos dados servirão para o planejamento e manejo desta vegetação, objetivando atingir os benefícios esperados.

No ambiente urbano, existem condições peculiares adversas à implantação e manejo da vegetação com relação ao ambiente natural, tais como a compactação e impermeabilização do solo, deficiências minerais, poluição do solo e do ar, impactos mecânicos produzidos pela ação antrópica e grandes aglomerados de construções. A compactação do solo dificulta ou mesmo pode impedir o desenvolvimento do sistema radicular das árvores, podendo promover deficiências nutricionais nas mesmas ou futuros acidentes pela deficiência na estrutura de sustentação da parte aérea. A impermeabilização superficial do solo, como ocorre mais visivelmente nas calçadas, agrava os problemas de deficiência nutricional dos solos urbanos, uma vez que quebra a ciclagem de nutrientes, quando as folhas são impedidas do contato com as raízes das árvores, também não chegando a constituir um folhedo como nas florestas em ambiente natural, pela remoção sistemática através das varrições constantes. Portanto, a reposição artificial de nutrientes tem que ser sistematizada pelos mantenedores desta vegetação através da adubação química ou orgânica.

A escolha das espécies arbóreas deve se orientar pelas funções pretendidas em cada sítio. Podemos dividir as áreas urbanas sujeitas à implantação de vegetação da seguinte forma: áreas de preservação permanente no ambiente urbano; parques municipais constituídos por área verde com estrutura mais complexa, contendo um ou mais ecossistemas aquáticos e terrestres; praças e jardins constituídos por área verde com estrutura mais simples e ordenamento artificial; canteiros ao longo de vias 
públicas; arborização de calçadas e ambientes de enclaves entre estas várias situações e com fragmentos de vegetação nativa remanescente.

Para arborização de calçadas impermeabilizadas, considerada situação mais adversa ao desenvolvimento e estabelecimento das árvores, a escolha das espécies deve ser extremamente criteriosa, considerando-se os seguintes aspectos:

a- sistema radicular

b- adaptabilidade ao meio (rusticidade)

c- arquitetura de copa

d- resistência ao ataque de pragas e doenças

e- características da madeira: dureza, resistência a fraturas e torções

f- velocidade de crescimento

g- vida útil

h- tolerância a podas e a impactos físicos

i- presença de elementos ou compostos tóxicos ou alérgicos na constituição química da espécie utilizada

j- disponibilidade de material propagativo e facilidade de reprodução em viveiro

k- ocorrência nativa

I- interações com fauna urbana

$\mathrm{m}$ - características nutricionais

$\mathrm{n}$ - porte quando adulta

o- estágio sucessional

aspectos do sítio:

a- rede elétrica presente ou ausente

b- largura da calçada e da via de rodagem

c- recuo das edificações da linha das calçadas 
d- espaço de superfície de solo permeável ao redor das árvores

e- nivel de compactação e permeabilidade do solo

$f$ - disponibilidade de nutrientes

g- drenagem

h- trânsito de pessoas e veículos

i- características culturais e socioeconômicas das populações humanas locais

Uma árvore ideal para plantio em calçadas deve ter copa densa para promover bom sombreamento, possuir folhas sempre verdes, de porte pequeno (4 a $6 \mathrm{~m}$ de altura) ou médio (de 4 a 8 metros de altura) quando adulta, em função das limitações do espaço físico urbano e presença de equipamentos públicos; raízes sub superficiais ou pivotantes profundas, para não promover grandes danos às estruturas civis; preferencialmente de espécie nativa, para contribuir para a manutenção da biodiversidade de flora e fauna; que não tenha frutos grandes, a fim de não provocar acidentes; não possuir princípios tóxicos ou alérgicos; tolerante às podas e a danos provocados por impactos físicos; farto material propagativo e de fácil propagação em viveiro; crescimento rápido; ciclo de vida médio ou longo; madeira resistente a torções e fraturas.

Para plantios em parques e jardins, em áreas mais amplas pode-se utilizar espécies de médio a grande portes, de todos os estágios sucessionais.

Um aspecto fundamental nesta escolha, ainda pouco considerado, é o estágio de sucessão vegetal ao qual a espécie deve pertencer.

Atualmente ainda existe uma tendência de se escolher espécies ditas de madeiras nobres ou de lei, de final de sucessão, de alto valor de mercado, para serem plantadas em calçadas. Freqüentemente estas espécies não são bem sucedidas, tanto na fase inicial de estabelecimento da muda, que neste caso é muito lento, quanto na fase adulta, pelo porte grande da copa, incompatível com o espaço físico urbano existente. 
O entendimento da dinâmica da sucessão vegetal natural poderá ser de grande importância na escolha das espécies mais adequadas, embora a arborização urbana se dê em um ambiente totalmente modificado pelo homem.

A sucessão secundária é um processo que ocorre em um ecossistema florestal após a destruição parcial da comunidade, que pode ser em uma pequena área, como em uma clareira aberta na floresta pela queda de uma árvore; ou em uma grande área, que pode ter sido devastada por furacões, incêndios ou para fins agrícolas. Nestas áreas, após a fase de perturbação, ocorre uma fase seguinte de cicatrização ou de regeneração da vegetação, através de uma progressiva mudança na composição florística da floresta, partindo de espécies pioneiras até as espécies climáxicas. Observando a dinâmica destas espécies, Budowski (1965) as classificou em quatro grupos ecológicos, sendo o das pioneiras, secundárias iniciais, secundárias tardias e clímax, cujas características são apresentadas na Tabela 1 abaixo.

Uma organização dos trabalhos para fins práticos pode ser feita, segundo Kageyama et al.(2000), separando em duas as situações de sucessão:

1. A que ocorre dentro da floresta primária;

2. A que ocorre após perturbações antrópicas em grande escala.

Esta classificação, ainda segundo o mesmo autor, auxilia o entendimento do comportamento e mudanças de habito de algumas espécies em situações antrópicas. Nesta perspectiva, Kageyama et al. (1994) dividem os grupos ecológicos silviculturais em situações de sucessão antrópica e sucessão secundária, apontando para uma sucessão diferenciada principalmente quanto à origem das espécies no início de sucessão. Assim sendo, as pioneiras antrópicas seriam aquelas não tipicamente pioneiras nas florestas primárias, mas que fazem o papel de pioneiras em áreas degradadas antrópicas, como o manacá e a bracatinga. As espécies secundárias/pioneiras antrópicas seriam as espécies secundárias e normalmente raras na floresta primária e que, em áreas antrópicas, desempenham o papel de pioneiras, como por exemplo o ipê felpudo e os angicos. 
Tabela 2. Algumas características das espécies florestais nativas do Brasil, dentro dos grupos sucessionais, que devem ser consideradas na escolha das espécies destinadas à arborização urbana (Budowiski (1965), adaptado por Barbosa et al., 1996)

\begin{tabular}{|c|c|c|c|c|}
\hline CARACTERISTICAS & $\begin{array}{l}\text { ESPÉCIE } \\
\text { PIONEIRA }\end{array}$ & $\begin{array}{l}\text { ESPÉCIE } \\
\text { SECUNDÁRIA } \\
\text { INICIAL }\end{array}$ & $\begin{array}{l}\text { ESPÉCIE } \\
\text { SECUNDÁRI } \\
\text { A TARDIA }\end{array}$ & $\begin{array}{l}\text { ESPÉCIE } \\
\text { CLÍMAX }\end{array}$ \\
\hline Ciclo de vida (anos) & Curto (1a 8) & Curto (5 a 15) & $\begin{array}{l}\text { Médio a longo } \\
(20 \text { a } 50)\end{array}$ & $\begin{array}{l}\text { Longo(mais } \\
\text { que 100) }\end{array}$ \\
\hline $\begin{array}{l}\text { Tamanho e quantidade } \\
\text { de sementes e frutos }\end{array}$ & $\begin{array}{l}\text { Pequenas e } \\
\text { em grande } \\
\text { quantidade }\end{array}$ & $\begin{array}{l}\text { Pequenas e em } \\
\text { grande } \\
\text { quantidade }\end{array}$ & $\begin{array}{l}\text { Depende da } \\
\text { espécie }\end{array}$ & $\begin{array}{l}\text { Grande e em } \\
\text { pouca } \\
\text { quantidade }\end{array}$ \\
\hline $\begin{array}{l}\text { Viabilidade de } \\
\text { sementes }\end{array}$ & $\begin{array}{l}\text { Longa, } \\
\text { latentes no } \\
\text { solo }\end{array}$ & $\begin{array}{l}\text { Longa, latentes } \\
\text { no solo }\end{array}$ & Curta a média & Curta \\
\hline $\begin{array}{l}\text { Disseminação de } \\
\text { sementes }\end{array}$ & $\begin{array}{l}\text { Pássaros, } \\
\text { morcegos e } \\
\text { vento }\end{array}$ & $\begin{array}{l}\text { Pássaros, } \\
\text { morcegos e } \\
\text { vento }\end{array}$ & $\begin{array}{l}\text { Principalmente } \\
\text { pelo vento }\end{array}$ & $\begin{array}{l}\text { Gravidade, } \\
\text { mamíferos e } \\
\text { coletores }\end{array}$ \\
\hline $\begin{array}{l}\text { Altura dos } \\
\text { indivíduos(em metros) }\end{array}$ & 4 a 8 & 20 & 20 a 30 & 30 a 45 \\
\hline $\begin{array}{l}\text { Tempo para atingir } \\
\text { altura máxima }\end{array}$ & $\begin{array}{l}\text { Muito } \\
\text { rápido } \\
\text { (alguns } \\
\text { meses) }\end{array}$ & $\begin{array}{l}\text { Rápido } \\
\text { (meses/anos) }\end{array}$ & $\begin{array}{l}\text { Variável com a } \\
\text { espécie (alguns } \\
\text { anos) }\end{array}$ & $\begin{array}{l}\text { Lento } \\
\text { (muitos anos } \\
\text { - mais de 10) }\end{array}$ \\
\hline Densidade da madeira & Muito leve & leve & $\begin{array}{l}\text { Intermediária, } \\
\text { variando com a } \\
\text { espécie }\end{array}$ & $\begin{array}{l}\text { Pesada e } \\
\text { rígida }\end{array}$ \\
\hline
\end{tabular}




\begin{tabular}{|c|c|c|c|c|}
\hline CARACTERÍSTICAS & $\begin{array}{l}\text { ESPÉCIE } \\
\text { PIONEIRA }\end{array}$ & $\begin{array}{l}\text { ESPÉCIE } \\
\text { SECUNDÁRIA } \\
\text { INICIAL }\end{array}$ & $\begin{array}{l}\text { ESPÉCIE } \\
\text { SECUNDÁRI } \\
\text { A TARDIA }\end{array}$ & $\begin{array}{l}\text { ESPÉCIE } \\
\text { CLÍMAX }\end{array}$ \\
\hline $\begin{array}{l}\text { Espessura dos ramos } \\
\text { das espécies } \\
\text { dominantes }\end{array}$ & $\begin{array}{l}\text { Muito finos } \\
\text { (diâmetro } \\
\text { menor que } \\
60 \mathrm{~cm} \text { ) }\end{array}$ & $\begin{array}{l}\text { Finos (diâmetro } \\
\text { até } 60 \mathrm{~cm} \text { ) }\end{array}$ & $\begin{array}{l}\text { Espessos(diâme } \\
\text { tro maior que } \\
80 \mathrm{~cm} \text { ) }\end{array}$ & $\begin{array}{l}\text { Muito } \\
\text { espessos } \\
\text { (diâmetro } \\
\text { maior que } 80 \\
\mathrm{~cm} \text { ) }\end{array}$ \\
\hline $\begin{array}{l}\text { Folhagem das espécies } \\
\text { dominantes }\end{array}$ & $\begin{array}{l}\text { Sempre } \\
\text { verdes }\end{array}$ & Sempre verdes & $\begin{array}{l}\text { Muitas são } \\
\text { decíduas }\end{array}$ & $\begin{array}{l}\text { Sempre } \\
\text { verdes }\end{array}$ \\
\hline Forma de regeneração & $\begin{array}{l}\text { Colonizam } \\
\text { qualquer } \\
\text { área }\end{array}$ & $\begin{array}{l}\text { Colonizam } \\
\text { grandes clareiras }\end{array}$ & $\begin{array}{l}\text { Colonizam } \\
\text { pequenas e } \\
\text { médias } \\
\text { clareiras }\end{array}$ & $\begin{array}{l}\text { Colonizam } \\
\text { áreas } \\
\text { sombreadas }\end{array}$ \\
\hline Necessidade de luz & $\begin{array}{l}\text { Muita luz } \\
\text { (heliófilas) }\end{array}$ & $\begin{array}{l}\text { Variável com a } \\
\text { espécie }\end{array}$ & $\begin{array}{l}\text { Variável com a } \\
\text { espécie }\end{array}$ & $\begin{array}{l}\text { Umbrófilas } \\
\text { quando } \\
\text { jovens, } \\
\text { necessitando } \\
\text { de luz } \\
\text { quando } \\
\text { adultas }\end{array}$ \\
\hline
\end{tabular}

Estudando a nutrição mineral de diferentes espécies florestais principalmente em seu estádio juvenil, Gonçalves et al. (2000)a observaram que o potencial de crescimento entre as espécies é bastante variável. Na medida em que se avança dos estágios iniciais para os finais de sucessão, ocorre uma menor taxa de crescimento, menor demanda e capacidade de absorção de 
nutrientes, as raízes finas passam a ter menores comprimentos e serem menos ramificadas e mais espessas, menor potencial de enovelamento das raízes em viveiro e menor potencial de resposta à fertilização.

Portanto, as espécies florestais de início de sucessão, como as pioneiras e secundárias iniciais, tem um potencial de crescimento e de absorção de nutrientes maior, com algumas exceções.

Pesquisando o sistema radicular de plantas em nível de viveiro e campo, Gonçalves et al. (1992) verificaram que as espécies com maiores taxas de crescimento, como as pioneiras e secundárias iniciais, apresentam maiores quantidades de raízes finas. Também observaram que estas espécies apresentam crescimento radicular mais rápido e com maior densidade de raízes finas, em sincronia com o maior potencial de expansão da área foliar e parte aérea como um todo. Com relação ao hábito de enraizamento, as pioneiras e secundárias iniciais apresentam, predominantemente, sistema radicular do tipo pivotante, bastante vigoroso e desenvolvido, explorando maior volume de solo em profundidade. As espécies finais de sucessão necessitam de sistemas radiculares com características distintas, adaptados às condições edáficas mais desenvolvidas e à maior competição entre as árvores. De acordo com Spurr et al. (1980), estas espécies são geralmente tolerantes a condições de baixa luminosidade.

Avaliando todas estas considerações, podemos admitir que as espécies mais adequadas para arborização urbana de calçadas estarão entre as pioneiras antrópicas e as secundárias, as quais em ambientes fortemente alterados, como as áreas urbanas, tem potencial maior de sucesso tanto na fase de implantação, quanto de estabelecimento.

\subsection{Potencial de risco}

Os metais pesados apresentam vários problemas para o meio ambiente, principalmente a longo prazo, não só por se acumularem nos 
organismos e entrarem na cadeia trófica, mas também por permanecerem nos ecossistemas em concentrações perigosas nos sedimentos, por um longo período.

A absorção de elementos metálicos pelas células, particularmente pelas raízes, é facilitada por mecanismos próprios de transporte e acumulação, pois vários metais pesados são realmente necessários às plantas como micronutrientes. No entanto, a planta não pode evitar a entrada de elementos tóxicos pelos mesmos mecanismos. Os metais pesados exercem um efeito tóxico devido, principalmente, à sua interferência no transporte eletrônico da respiração e da fotossintese e na inativação de enzimas vitais. Isto baixa o nivel energético e reduz a absorção de nutrientes e do crescimento (Larcher, 2000).

Pela presença de metais pesados no biossólido, oriundos de efluentes industriais despejados nos mananciais conjuntamente com esgotos domésticos, é fundamental sua monitoração e avaliação de seus efeitos no meio ambiente. Uma das técnicas utilizadas é a realizada através de bioindicadores. Os parâmetros microbianos parecem ser muito úteis na avaliação da poluição do solo, segundo Cardoso et al. (2000). Para se determinarem as ações de agentes poluentes de lodo de esgoto sobre as atividades e a dinâmica das comunidades microbianas no solo, os parâmetros mais utilizados são: liberação de $\mathrm{CO}_{2}$; biomassa de carbono; atividade enzimática; contagem de microorganismos fixadores de nitrogênio e mineralização de nitrogênio. Em trabalho de pesquisa desenvolvido na Estação Experimental de Itatinga, os mesmos autores concluíram que a adição de biossólido no solo proporcionou aumentos na respiração basal e no coeficiente metabólico, o que resultou em maior perda de carbono no solo, não aumentou a biomassa microbiana do solo, mas estimulou a atividade microbiana celulolíticas. Concluíram também que os parâmetros estudados foram sensiveis às alterações provocados pelas doses de lodo aplicadas ao solo. 
As normas para utilização de biossólido no Estado de São Paulo estão em fase de aprovação pela CETESB em um Manual Técnico que define critérios para a elaboração de projetos, implantação e operação de sistemas de aplicação de lodos de esgoto na agricultura, visando a atender às exigências ambientais (Straus, 2000). A legislação vigente no Estado de São Paulo prevê que o solo somente poderá ser usado para a destinação de resíduos mediante a adoção de técnicas adequadas estabelecidas em projetos especificos aprovados pela CETESB.

A definição de diretrizes e padrões para o uso de biossólido na agricultura, florestas e paisagismo é indispensável para que este uso tenha seus riscos minimizados com relação à saúde pública. Segundo Hespanhol (2001), a diretriz microbiológica associa a taxa de aplicação (ton ${ }_{85} / \mathrm{ha} / \mathrm{ano}$ ) às concentrações de ovos de helmintos (ovos $/ \mathrm{g}_{85}$ ) identificadas no biossólido a ser aplicado, enquanto que a diretriz química estabelece concentrações máximas de determinados poluentes a serem atingidas $(\mathrm{mg} / \mathrm{kg}$ de solo, base seca) visando proteger a saúde pública dos consumidores de alimentos, produzidos em solos agrícolas fertilizados com biossólido.

A avaliação prévia de impactos potenciais ao meio ambiente e a seus habitantes pela ação antrópica pode ser realizada através de processo de avaliação de risco (Cunha, 2000). A avaliação de risco é definida como a caracterização do potencial de efeitos adversos à saúde de indivíduos expostos aos perigos ambientais pelo Conselho Nacional de Pesquisa dos EUA. Define-se o risco como sendo a probabilidade de uma ocorrência indesejável sob uma determinada circunstância. A metodologia de avaliação de risco, decorrente de processo desenvolvido pela Academia Nacional de Ciências dos EUA em 1983, considera as seguintes etapas: coleta e avaliação dos dados, avaliação da toxicidade e das vias de exposição, bem como a caracterização do risco.

Desenvolvendo trabalhos sobre riscos de contaminação do agroecossistema com parasitos pelo uso do lodo de esgoto, Soccol (2000) 
recomendam práticas para minimizá-los, tais como emprego de produtos tratados e higienizados por processos previamente definidos para uso em áreas com atividades agropecuárias e urbanas abertas para visitação pública e uso de área para produção de alimentos, a serem consumidos crus somente após 12 meses da aplicação do lodo.

Estudando a entrada de metais pesados na cadeia alimentar, Berton (2000), cita Chaney \& Oliver (1996) que afirmam que as plantas se comportam tanto como um mecanismo de transferência de contaminantes do solo para níveis mais altos na cadeia trófica, como uma importante barreira para esta transferência. Afirma ainda que as plantas em geral restringem a absorção da maioria dos elementos do solo, de forma que os seres humanos, os animais e a vida selvagem não se encontram sob nenhum risco em relação a presença dos metais no solo.

Em algumas áreas destinadas a parques e jardins em Los Angeles Estados Unidos, vêm sendo aplicados, há cerca de 40 anos, compostos à base de lodo de esgoto. Análises realizadas em amostras desses solos, têm revelado que os metais pesados presentes em maiores teores são: $\mathrm{Cd}, \mathrm{Cu}, \mathrm{Ni}$, $\mathrm{Pb}$ e Zn. Segundo Wallace \& Wallace (1994) citados por Marqueset al. (2001), sintomas de toxidez por $\mathrm{Cu}$ e $\mathrm{Zn}$ têm aparecido nas plantas, sempre que os teores desses elementos nos solos excederam os níveis de 20 e $80 \mathrm{mg} \mathrm{kg-}^{-1}$, respectivamente.

Apesar do potencial contaminante do uso agrícola do lodo de esgoto, mais de 50.000 trabalhos foram publicados no mundo e nenhum efeito adverso foi encontrado quando o uso foi controlado pelas diferentes regulamentações, segundo Andreoli et al. (2000). Também afirma que sua utilização em solos agrícolas desgastados por manejo inadequado e para recuperação de áreas degradadas é particularmente interessante. Para tanto, afirma que esta via depende de um adequado planejamento baseado num conjunto de medidas tais como: estimativa de produção , avaliação da qualidade, aptidão das áreas 
de aplicação, organização e operação da distribuição, alternativas de higienização, adequações necessárias a ETE e monitoramento ambiental.

Tendo-se em vista o potencial cumulativo de metais pesados ao longo do tempo, em conseqüência de sucessivas aplicações de biossólido, Gonçalves et al.(2000)b afirma que se administrando $20 \mathrm{Mg} \mathrm{ha}^{-1}$ de biossólido (base seca), com intervalos de sete anos em plantações de eucaliptos concluise que seriam necessários $665,420,525,595$ e 2450 anos para atingir a carga máxima acumulada de $\mathrm{Cd}, \mathrm{Ni}, \mathrm{Pb}, \mathrm{Zn}, \mathrm{Cu}$ e $\mathrm{Hg}$, respectivamente, permitida pela CETESB. 


\section{MATERIAL E MÉTODOS}

\subsection{Localização}

O trabalho experimental foi instalado em casa de vegetação, em uma propriedade produtora de mudas, localizada no Distrito de Sousas, município de Campinas, Estado de São Paulo, a $650 \mathrm{~m}$ de altitude, coordenadas geográficas $46^{\circ} 55^{\prime} 58^{\prime \prime}$ de latitude oeste e $22^{\circ} 50^{\prime} 13^{\prime \prime}$ de longitude sul.

\subsection{Características da casa de vegetação}

A estufa é construída em estrutura metálica, revestida em sua parte superior com filme de polietileno transparente, com 200 micras de espessura e revestida lateralmente com tela de nylon, do tipo sombrite, com $50 \%$ de sombra em toda sua extensão lateral. Ela é dotada de sistema de irrigação por microaspersão, com alimentação de água por meio de sistema de recalque, controlado por programador horário eletromecânico, permitindo controle fino da quantidade de água administrada. Possue 9 metros de largura por $12 \mathrm{~m}$ de comprimento, totalizando $110 \mathrm{~m}^{2}$.

\subsection{Características do experimento}

O experimento foi constituído pelo plantio de mudas de espécies florestais nativas em potes de polietileno, dispostos sobre bancada, no interior da casa de vegetação (Figura 1), onde foram acompanhadas por um período de 100 dias, considerado adequado para a observação de mudas de 
exemplares arbóreos, sem que houvesse deformação de suas raízes, no período de novembro de 2003 a fevereiro de 2004.

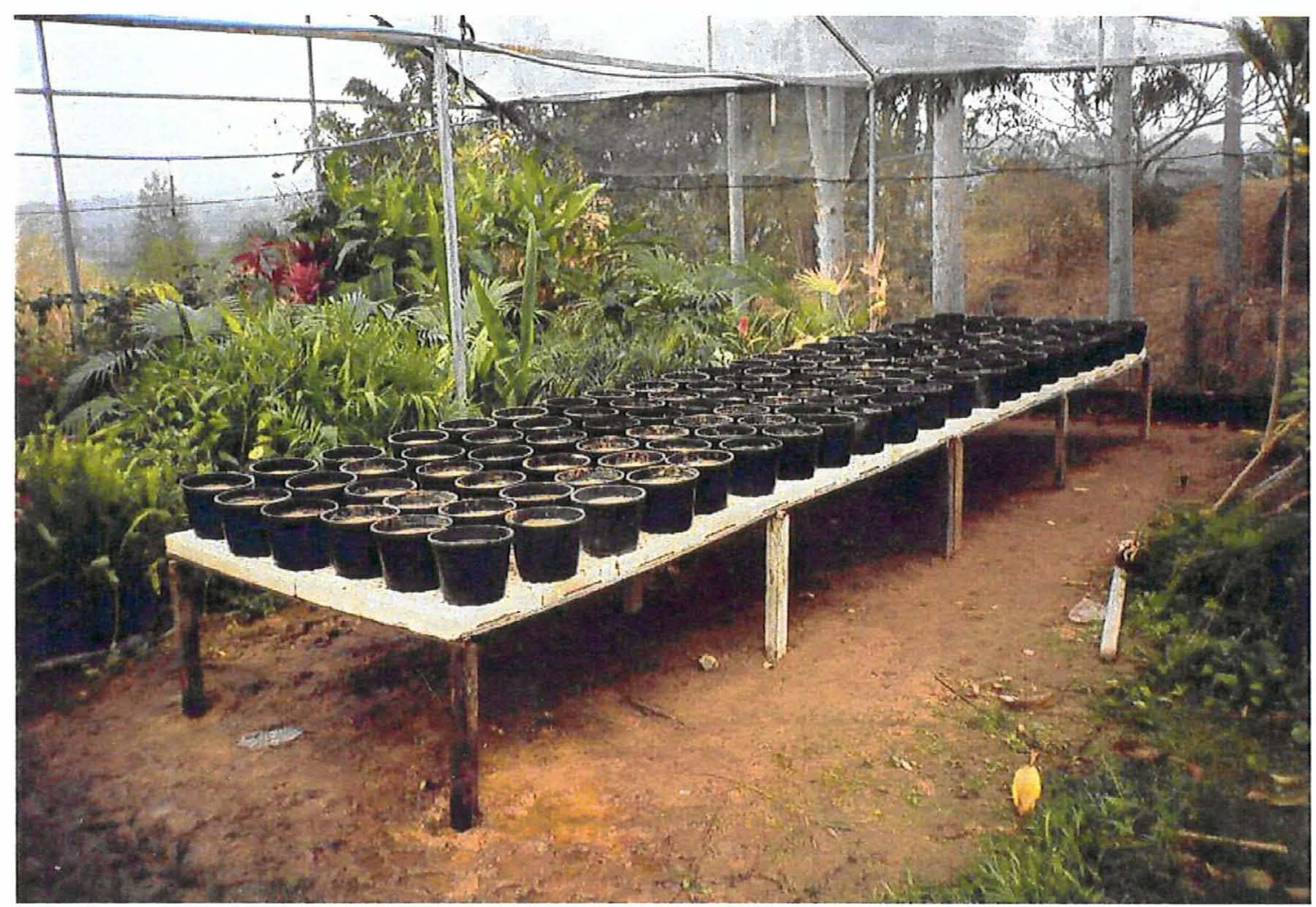

Figura 1 - Bancada com os potes no interior da casa de vegetação

Foram quatro espécies cultivadas em potes com solo calado, que receberam sete tratamentos, sendo uma testemunha, um tratamento com adubação mineral completa e cinco doses diferentes de biossólido suplementados com potássio, conforme Tabela 3. O delineamento estatístico utilizado foi inteiramente casualizado, com quatro repetições, totalizando 112 potes. 
Tabela 3 . Tratamentos com nutrientes aplicados ao experimento

\begin{tabular}{|c|c|c|c|c|c|c|c|c|c|}
\hline TRATAMENTOS & $\begin{array}{c}\text { SOLO } \\
\text { litros pote.................. }\end{array}$ & ton. ha. & 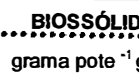 & $\begin{array}{l}\text { DO...................... } \\
\text { grama dm }\end{array}$ & $\underset{\text { grama pote }}{\text { POTASSIO }}$ & $\begin{array}{l}\text { CALCÁRIO } \\
\text { grama pote............... }^{-1}\end{array}$ & $\begin{array}{c}\text { MICRONUT } \\
\text { grama pote }\end{array}$ & $\begin{array}{l}\text { U................. } \\
\text { grama pote }^{-1}\end{array}$ & $\begin{array}{l}\text { FóSF........... } \\
\text { grama pote }\end{array}$ \\
\hline TESTEMUNHA & 4 & 0 & 0 & 0.00 & 0.00 & 2.5 & 0 & 0 & 0 \\
\hline ADUBO MINERAL & 4 & 0 & 0 & 0.00 & 0.67 & 2.5 & 0.8 & 1.5 & 7 \\
\hline $1.25 \mathrm{dm}^{-3}$ & 4 & 2.5 & 5 & 1.25 & 0.65 & 2.5 & 0 & 0 & 0 \\
\hline $2.50 \mathrm{dm}^{-3}$ & 4 & 5 & 10 & 2.50 & 0.64 & 2.5 & 0 & 0 & 0 \\
\hline $5.00 \mathrm{dm}^{-3}$ & 4 & 10 & 20 & 5.00 & 0.60 & 2.5 & 0 & 0 & 0 \\
\hline $10.00 \mathrm{dm}^{-3}$ & 4 & 20 & 40 & 10.00 & 0.54 & 2.5 & 0 & 0 & 0 \\
\hline $2.00 \mathrm{dm}^{-3}$ & 4 & 40 & 80 & 20.00 & 0.42 & 2.5 & 0 & 0 & 0 \\
\hline
\end{tabular}

O solo utilizado foi o encontrado na região do experimento, anteriormente caracterizado por podzólico vermelho amarelo, textura média arenosa (PRADO,1997), atualmente caracterizado por argissolo vermelho amarelo, PVA 20, distrófico A moderado (OLIVEIRA, 1999), cujas características físico- químicas encontram-se nas Tabela 4 e 5 . Coletou-se o solo da camada superficial, após a remoção da vegetação e da camada orgânica do mesmo, que foi transportado para o interior da estufa, depositado sobre um filme de polietileno, peneirado, e promovida a medição de volume suficiente para enchimento de 112 potes. Em seguida, aplicou-se a cal agrícola na quantidade descrita na tabela 3 , sendo homogeneizada com o solo.

Tabela 4 . Macronutrientes encontrados no solo utilizado no experimento

\begin{tabular}{|c|c|c|c|c|c|c|c|c|c|c|c|c|}
\hline $\begin{array}{l}\mathrm{PH} \\
\mathrm{CaCl}_{2}\end{array}$ & $\begin{array}{l}\mathrm{M} . \mathrm{O} \\
\mathrm{g} / \mathrm{dm}^{-3}\end{array}$ & $\begin{array}{l}P \\
\mathrm{mg} / \mathrm{dm} \\
3\end{array}$ & $\begin{array}{l}\mathrm{S} \\
\mathrm{mg} / \mathrm{dm}^{-} \\
3\end{array}$ & $\begin{array}{l}\mathrm{K} \\
\mathrm{mmolc} \\
\mathrm{dm}^{-3}\end{array}$ & $\begin{array}{l}\mathrm{Ca} \\
\mathrm{mmolc} \\
\mathrm{dm}^{3}\end{array}$ & $\begin{array}{l}\mathrm{Mg} \\
\text { mmolc } \\
\mathrm{dm}^{-3}\end{array}$ & $\begin{array}{l}\text { Al } \\
\text { mmolc } \\
\mathrm{dm}^{-3}\end{array}$ & $\begin{array}{l}\mathrm{H}+\mathrm{Al} \\
\mathrm{mmlc} \\
\mathrm{dm}^{-3}\end{array}$ & $\begin{array}{l}\mathrm{SB} \\
\text { mmotc } \\
\mathrm{dm}^{-3}\end{array}$ & $\begin{array}{l}T \\
\text { mmolc } \\
\mathrm{dm}^{3}\end{array}$ & $\begin{array}{l}\mathbf{V} \\
\%\end{array}$ & $\begin{array}{l}M \\
\%\end{array}$ \\
\hline 4,3 & 15 & 2 & 4 & 2 & 12 & 4 & 4 & 31 & 18 & 49 & 37 & 18 \\
\hline $\mathrm{MB}$ & $\mathrm{MB}$ & MB & & $\bar{M}$ & $\mathbf{A}$ & B & & & & & B & \\
\hline
\end{tabular}

Análises realizadas pelo laboratório de análise de solo do Departamento de Solos da ESALQ

$M B=$ Muito Baixo; $B=$ Baixo; $M=$ Médio; $A=$ Alto; $M A=$ Muito Alto; (Fonte: Boletim técnico IAC, 1996) 
A quantidade de calcário foi calculada segundo recomendações de Gonçalves \& Benedetti (2000), pela fórmula:

$\mathrm{NC}=\mathrm{CTC}\left(\mathrm{V}_{2}-\mathrm{V}_{1}\right) / 20 \mathrm{PRNT}$, onde:

$\mathrm{NC}=$ necessidade de calcário em $\mathrm{kg} \mathrm{m}^{-3}$

CTC $=$ Capacidade de Troca de Cátions

$V_{2}=$ Saturação de base desejada

$V_{1}=$ Saturação de base encontrada no solo utilizado

$\mathrm{NC}=49(60-37) / 20^{*} 90=0,626 \mathrm{~g} \mathrm{~m}^{-3}$ de solo, equivalente a $2,5 \mathrm{~g}$ para 4 litros de solo (por pote).

Tabela 5. Micronutrientes encontrados no solo utilizado no experimento

\begin{tabular}{ccccc}
\hline $\left.\mathrm{B}(\mathrm{mg} \mathrm{dm})^{-3}\right)$ & $\mathrm{Cu}\left(\mathrm{mg} \mathrm{dm}^{-3}\right)$ & $\mathrm{Fe}\left(\mathrm{mg} \mathrm{dm}^{-3}\right)$ & $\mathrm{Mn}\left(\mathrm{mg} \mathrm{dm}^{-3}\right)$ & $\mathrm{Zn}\left(\mathrm{mg} \mathrm{dm}^{-3}\right)$ \\
\hline 0.10 & 0.3 & 26 & 30.7 & 1.3 \\
$\mathrm{~A}$ & $\mathrm{M}$ & $\mathrm{A}$ & $\mathrm{A}$ & $\mathrm{A}$ \\
\hline
\end{tabular}

Análises realizadas pelo laboratório de análise de solo do Departamento de Solos da ESALQ

Características físicas:

Areia - $68 \%$; Silte $-12 \%$; Argila $-20 \%$

Entre os sete tratamentos com nutrientes, cinco foram constituídos por doses diferentes de biossólido seco termicamente e granulado, cujas características químicas estão descritas na Tabela 6, suplementados com potássio, nas quantidades descritas na Tabela 3. $O$ tratamento com adubação mineral foi constituído por cal agrícola dolomítico PRNT 90 \% e adubação mineral completa com macro e micronutrientes, também descritos na Tabela 3. 
A testemunha foi constituída apenas pelo solo e cal agrícola dolomítico PRNT $90 \%$. O biossólido foi administrado superficialmente, com incorporação rasa.

Tabela 6. Parâmetros de caracterização do biossólido gerado pela ETE de Barueri, utilizado no experimento. (Lodo floculado com polieletrólito (poliacrilamida), seco termicamente e granulado)

\begin{tabular}{|c|c|c|}
\hline PARÂMETROS & UNIDADE & AMOSTRA \\
\hline $\mathrm{pH}$ (água-relação $1: 5$ ) & & 7 \\
\hline U m idade $65^{\circ} \mathrm{C}$ & g k g-1 & 60,61 \\
\hline C orgânico & $\mathrm{g} \mathrm{kg-1}^{-1}$ & 333,89 \\
\hline M atéria orgânica total & g k g-1 & 564,6 \\
\hline Condutividade & $\mathrm{m} \mathrm{S} / \mathrm{cm}$ & 3,68 \\
\hline N kjeldahl & g k g-1 & 39,64 \\
\hline$P$ & g k g-1 & 17,01 \\
\hline K & g kg-1 & 1,88 \\
\hline $\mathrm{Ca}$ & g k g-1 & 32,67 \\
\hline$M g$ & g k g-1 & 4,11 \\
\hline $\mathrm{Na}$ & $\mathrm{g} \mathrm{kg-1}^{-1}$ & 0,73 \\
\hline S & g kg-1 & n a \\
\hline$M n$ & $\mathrm{~m} \mathrm{~g} \mathrm{kg-1}$ & 4,113 \\
\hline $\mathrm{Fe}$ & $m \mathrm{~g} \mathrm{kg-1}^{-1}$ & 38,283 \\
\hline Al & $\mathrm{m} \mathrm{g} \mathrm{kg-1}$ & 27,821 \\
\hline $\mathrm{Zn}$ & $m \mathrm{~g} \mathrm{kg-1}^{-1}$ & 3,037 \\
\hline $\mathrm{Ni}$ & $\mathrm{m} \mathrm{g} \mathrm{kg-1}$ & 316 \\
\hline $\mathrm{Cu}$ & $m \mathrm{~g} \mathrm{~kg} \mathrm{-}^{-1}$ & 848 \\
\hline Crtotal & $m \mathrm{~g} \mathrm{kg-1}^{-1}$ & 700 \\
\hline $\mathrm{Pb}$ & $m g k g-1$ & 191 \\
\hline C. d & $\mathrm{mg} \mathrm{kg-1}$ & 0,1 \\
\hline As & $\mathrm{mg} \mathrm{kg-1}$ & $\mathrm{n} a$ \\
\hline $\mathrm{Hg}$ & $\mathrm{m} \mathrm{g} \mathrm{kg-1}$ & $\mathrm{na}$ \\
\hline Mo & $\mathrm{m} \mathrm{g} \mathrm{kg-1}$ & $\mathrm{na}$ \\
\hline $\mathrm{Se}$ & $\mathrm{m} \mathrm{g} \mathrm{kg-1}$ & $\mathrm{na}$ \\
\hline
\end{tabular}

na = análises ainda não realizadas

Resultados de análises realizadas no Laboratório de Quimica Ambiental do Departamento de Ciências Exatas da ESALQ/USP.

Taxa de degradação da fração orgânica do lodo: $21 \%$, obtida por ensaio de acordo com a Norma P4.230 da CETESB (1999).

Taxa de mineralização do nitrogênio: $13 \%$ aos 56 dias. 
A definição das dosagens de biossólido por pote foi em função do teor de nitrogênio necessário para fornecer $150 \mathrm{~g}$ de $\mathrm{N}$ na composição de 1000 litros de substrato recomendado por Gonçalves et al. (2000)a. Se fosse considerado o nitrogênio total do biossólido utilizado (com $39,64 \mathrm{~g} \mathrm{~kg}^{-1}$ de $\mathrm{N}$ ), para fornecer a quantidade de $\mathrm{N}$ recomendada, seriam necessários $15,1 \mathrm{~g}$ de biossólido por pote, correspondentes a $3,78 \mathrm{~g} \mathrm{dm}^{3}$ ou ainda a 7,57 toneladas por hectare. Se fosse considerado que apenas $13 \%$ do nitrogênio foi mineralizado em 56 dias, estes valores iriam para 116,50g de biossólido por pote de 4 litros, correspondentes a $29,12 \mathrm{~g} \mathrm{dm}^{-3}$, ou a $58,25 \mathrm{t} / \mathrm{ha}$. Se fosse considerada a taxa mínima de mineralização de $30 \%$ aos 126 dias exigidos pela CETESB (1999), seriam necessários $50,46 \mathrm{~g}$ de biossólido por pote, correspondentes a 12,61 $\mathrm{g}$ de biossólido por $\mathrm{dm}^{-3}$, ou a 25,23 t/ha. Considerando que os trabalhos recentes desenvolvidos pela ESALQ na estação experimental de Itatinga têm utilizado dosagens entre 10 e 40 toneladas ha ${ }^{-1}$, obtendo bons resultados com dosagens próximas a $40 \mathrm{t} \mathrm{ha}^{-1} \mathrm{e}$ os riscos de efeitos fitotóxicos do biossólido em sistemas fechados como potes podendo vir a comprometer parcelas e inviabilizar experimentos, optou-se por dosagens entre 2,5 e $40 \mathrm{t} \mathrm{ha}^{-1}$ ( 5 a $80 \mathrm{~g}$ por pote). Este intervalo contempla o fornecimento de $150 \mathrm{~g}$ por $1000 \mathrm{I}$ de substrato recomendado por Gonçalves et al. (2000)a, considerando $30 \%$ de taxa de mineralização do nitrogênio exigidos pela CETESB (1999), na dose de 50,46 g de biossólido por pote.

A suplementação mineral com $\mathrm{KCl}$ foi definida para o fornecimento total de $100 \mathrm{~g}$ de $\mathrm{K}_{2} \mathrm{O}$ por 1000 litros de substrato.

A dosagem de fósforo para a adubação mineral foi definida para fornecimento total de $700 \mathrm{~g}$ de $\mathrm{P}_{2} \mathrm{O}_{5}$ para $1000 \mathrm{I}$ de substrato na forma de superfosfato triplo. A quantidade de cal agrícola foi definida tendo como base os resultados da análise de fertilidade de uma amostra do solo a ser utilizado para compor o substrato. A cal agrícola foi administrada 30 dias antes da aplicação da fonte de fósforo. 
Os potes de polietileno rígido possuíam diâmetro de $16,5 \mathrm{~cm}$ na base e de $21,5 \mathrm{~cm}$ entre as bordas superiores, com $17 \mathrm{~cm}$ de altura, oferecendo volume útil de 4 litros.

A água foi administrada em função da demanda pelas plantas, considerando a umidade relativa do ar e o estádio médio de desenvolvimento das mesmas, mantida próxima à capacidade de campo, não havendo no período estresse pelas plantas por falta ou excesso de água. Também o excesso de água foi evitado para se minimizar as perdas de nutrientes por lixiviação.

Tabela 7 . Parâmetros de caracterização da água utilizada para irrigação

\begin{tabular}{lllrlr}
\hline $\begin{array}{l}\text { PARÂMETROS } \\
\text { SALINIDADE }\end{array}$ & UNID & VAL NORMAIS' & VAL.da amostra & \multicolumn{2}{c}{ OBS } \\
$\begin{array}{l}\text { Condutividade elétrica } \\
\text { CATIONS E ÂNIONS }\end{array}$ & $\mathrm{dS} / \mathrm{m}$ & $0-3$ & 0.17 & normal \\
Calcio & & & 52 & alto \\
Magnésio & $\mathrm{meq} / \mathrm{l}$ & $0-20$ & 2.6 & normal \\
Sódio & $\mathrm{meq} / \mathrm{l}$ & $0-5$ & 19 & normal \\
Cloreto & $\mathrm{meq} / \mathrm{l}$ & $0-40$ & 3 & normal \\
Sulfatos & $\mathrm{meq} / \mathrm{l}$ & $0-30$ & 6.4 & normal \\
OUTROS NUTRIENTES & $\mathrm{meq} / \mathrm{l}$ & $0-20$ & & \\
Nitrato & & & 5.8 & normal \\
Fósforo & $\mathrm{mg} / \mathrm{l}$ & $0-10$ & 0.01 & normal \\
Potássio & $\mathrm{mg} / \mathrm{l}$ & $0-2$ & 1.1 & normal \\
Alcalinidade & $\mathrm{mg} / \mathrm{l}$ & $0-2$ & 7.8 & normal \\
\hline
\end{tabular}

Valores adaptados de Ayers \& West Cot (1991)

A temperatura interna foi acompanhada no período com um termômetro de máximas e mínimas do tipo capela, colocado no interior da estufa, sendo observadas as médias máximas em $36,46{ }^{\circ} \mathrm{C}$, médias mínimas em $16,50^{\circ} \mathrm{C}$ e 
médias de $26,48{ }^{\circ} \mathrm{C}$. Observam-se grandes variações de temperaturas diurnas e noturnas, típicas da região.

\subsection{Caracterização das espécies utilizadas}

Foram utilizadas espécies nativas, amplamente encontradas na arborização de vias públicas, parques e jardins. Suas mudas foram obtidas junto a um viveiro comercial da região, retiradas de lotes cujos indivíduos possuiam características homogêneas em altura e vigor, produzidas em tubetes de $56 \mathrm{cc}$.

Principais características:

\subsubsection{Aroeira-pimenteira (Schinus terebinthifolia Raddi)}

Espécie de porte arbóreo da família anacardiaceae, podendo atingir 5 a $10 \mathrm{~m}$ de altura, com arquitetura de copa arredondada. Tronco tortuoso, de 30 a $60 \mathrm{~cm}$ de diâmetro, com casca grossa e fissurada. Folhas compostas imparipenadas. Folíolos subcoriáceos, glabros, em número de 3 a 5 pares, de 1 a $5 \mathrm{~cm}$ de comprimento por 1 a $3 \mathrm{~cm}$ de largura.

Ocorre do Rio Grande do Sul ao Pernambuco, em várias formações florestais. Sua madeira é moderadamente pesada, medianamente dura, textura média, bastante resistente e de grande durabilidade natural, utilizada para moirões, esteios, lenha e carvão.

A árvore é muito ornamental, principalmente durante o longo período em que os frutos persistem na planta. Pelo porte pequeno, é indicada para arborização de calçadas de ruas estreitas e sob rede elétrica (Lorenzi, 98). Planta perenifólia, heliófita e pioneira. 


\subsubsection{Cabreúva - vermelha (Myroxylon peruiferum L. f.)}

Espécie de porte arbóreo da família Leguminosa-Papilionoideae, podendo atingir de 10 a $20 \mathrm{~m}$ de altura, com tronco de 60 a $80 \mathrm{~cm}$ de diâmetro. Suas folhas são compostas pinadas, com 9 a 13 folíolos glabros na página superior, de 5 a $10 \mathrm{~cm}$ de comprimento.

Ocorre em quase todo o país, principalmente na floresta latifoliada semidecídua da bacia do Paraná, mata pluvial atlântica da Bahia, Espírito Santo e zona da mata de Minas Gerais, floresta equatorial da parte sul e sudoeste da região amazônica e até na caatinga do nordeste brasileiro.

Sua madeira é pesada (densidade de $0,95 \mathrm{~g} / \mathrm{cm}^{3}$ ), dura, de média resistência mecânica, grã geralmente revessa, de alta resistência ao apodrecimento. A madeira é própria para mobiliário, revestimentos decorativos, produção de folhas faqueadas, peças torneadas, para construção civil, como tábuas e tacos para assoalho, portas e janelas, batentes, caibros, ripas, para obras externas, como mourões, postes, dormentes, vigas para pontes, para carrocerias, mancais, rodas de carroças, etc. $O$ tronco fornece por lesão, o bálsamo de tolu, empregado em perfumaria.

A árvore é ornamental e pode ser utilizada no paisagismo e arborização urbana.

Planta decídua, heliófita ou esciófita, indiferente às condições físicas do solo, característica da floresta latifoliada semidecídua. Ocorre tanto no interior da mata primária densa, como nas formações secundárias (Lorenzi, 98). É espécie de final de sucessão, considerada como secundária tardia ou climáxica.

\subsubsection{Pau-de-viola (Cytarexyllum myrianthum Cham)}

Espécie de porte arbóreo da família verbenaceae, com altura de 8 a 20 metros, tronco de 40 a $60 \mathrm{~cm}$ de diâmetro. Folhas subcoreáceas, face inferior 
de coloração mais clara e com nervuras pubescentes e de coloração mais clara e com nervuras pubescentes e de coloração marrom-clara, de 10 a 20 $\mathrm{cm}$ de comprimento por 3 a $7 \mathrm{~cm}$ de largura.

Ocorre do Rio Grande do Sul a Bahia, na floresta pluvial atlântica e matas de galeria.

Possui madeira leve, macia ao corte, textura grossa, de baixa durabilidade natural, principalmente quando exposta. A madeira pode ser aproveitada para tabuado em geral, para forros, confecção de brinquedos, artefatos leves, caixotaria, etc. Os frutos são muito apreciados por várias espécies de pássaros. As flores são meliferas.

Espécie pioneira de crescimento rápido, decídua, heliófita, seletiva higrófita, característica das florestas de galeria e pluvial atlântica. Também é considerada espécie secundária inicial por outros autores como Carvalho (1994) e Gonçalves et al. (2000). Neste trabalho de tese adotaremos a classificação como sendo secundária inicial.

Pela abundância de frutos para a avifauna, copa de porte médio e grande adaptabilidade ao ambiente urbano a mesma presta-se à arborização de calçadas de avenidas, praças e parques (Lorenzi, 98).

\subsubsection{Unha-de-vaca (Bauhinia forficata Link )}

Espécie de porte arbóreo da família Caesalpinoidea, com copa pequena entre 5 a 9 metros de altura, com tronco tortuoso de 30 a $40 \mathrm{~cm}$ de diâmetro. Folhas glabras ou levemente pubescentes na face dorsal, divididas até acima do meio, com 8 a $12 \mathrm{~cm}$ de comprimento. Acúleos quase sempre gêmeos.

Ocorre do Rio Grande do Sul ao Rio de Janeiro e Minas Gerais, principalmente na floresta pluvial atlântica.

Possui madeira moderadamente pesada, mole, de baixa durabilidade quando exposta ao tempo. É empregada para caixotaria, obras leves e carvão. Suas flores contrastam com a cor verde das folhas, tornando-a 
bastante ornamental, sendo recomendadas para o paisagismo e arborização de ruas estreitas e sob rede elétrica.

Planta decídua ou semidecídua, heliófita, pioneira, característica da floresta pluvial atlântica (Lorenzi, 98).

\subsection{Metodologia de coleta, preparo e análise do material}

\subsubsection{Medições de altura e diâmetro de colo, coleta de folhas, caules e raizes}

A altura e diâmetro de colo foram medidas aos zero, trinta, sessenta e cem dias da instalação do experimento, através de uma trena milimetrada e paquímetro com precisão em décimos de milimetro.

Após 100 dias do início do experimento (Figura 2), realizou-se a coleta do material. As folhas foram colhidas e acondicionadas em sacos de papel devidamente etiquetados com o número do tratamento. Após o que o material remanescente foi retirado cuidadosamente dos potes e lavado com água limpa. Separou-se o caule das raízes, que foram acondicionados em sacos de papel também devidamente identificados. Este material foi encaminhado para o Laboratório de Ecologia Aplicada do Departamento de Ciências Florestais da ESALQ/USP, para secagem em estufa com temperatura controlada em $65^{\circ} \mathrm{C}$, onde permaneceu até atingir peso constante. 


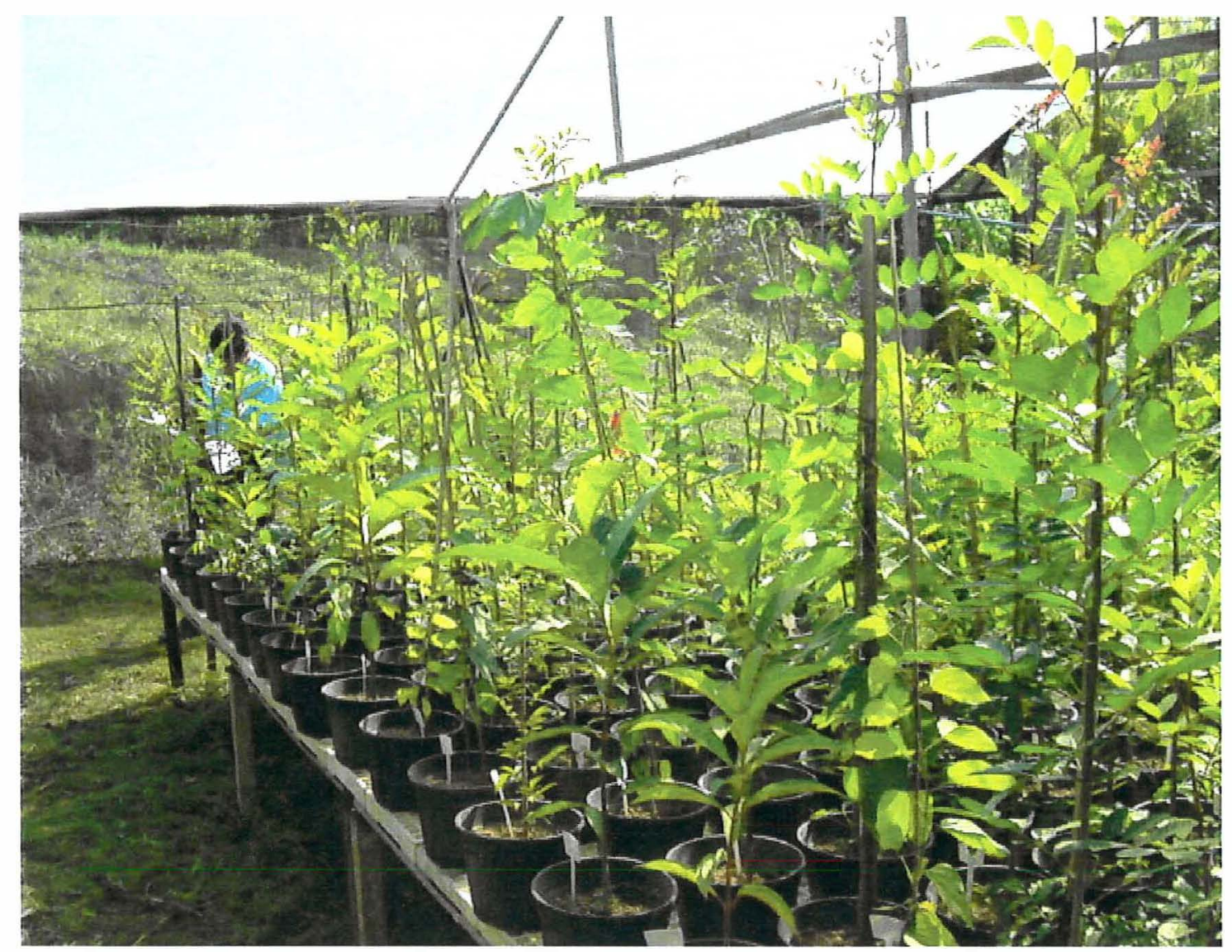

Figura 2 - Experimento aos 100 dias

Em seguida, realizou-se a pesagem do material e registro dos dados de peso de matéria seca das três partes. O passo seguinte foi a moagem das amostras do material em moinho do Laboratório, sendo submetidos às análises laboratoriais nos parâmetros estabelecidos.

O solo foi colhido dos potes através de amostra composta por tratamento, constituindo sete amostras, também encaminhadas ao LEA para análise de parâmetros estabelecidos. 


\subsubsection{Parâmetros acompanhados}

1) altura (zero, trinta, sessenta e cem dias);

2) diâmetro de colo (zero, trinta, sessenta e cem dias);

3) matéria seca das folhas, caule e de raízes;

4) macro e micronutrientes nas folhas, caules, raizes e substratos. Nos caules e substratos, foi coletada amostra composta, sem repetições, para redução de custos das análises, com a finalidade adequação aos recursos financeiros disponiveis.

5) metais pesados nas folhas, raizes e substratos. Nos caules e substratos, foi coletada amostra composta, sem repetições, para redução de custos das análises, com a finalidade adequação aos recursos financeiros disponiveis;

\subsection{Análise estatística dos dados}

Para se verificar o nivel de significância entre os tratamentos, realizouse análise de variância - ANOVA, comparando as médias entre os grupos de dados levantados de cada parâmetro estudado. Após a constatação de diferenças significativas, realizou-se a comparação de médias através do teste Tukey a $5 \%$ de probabilidade. Para o parâmetro matéria seca realizou-se análise de correlação linear, dada pela equação $y=a+b x$.

Utilizou-se o programa estatístico BIOESTAT versão 3.0, desenvolvido pela Sociedade Civil Mamirauá/MCT, CNPq, Belém, Pará, 2003 para análise dos dados.

Para caracterizar os nutrientes utilizados, bem como a taxa de transferência de metais pesados para as plantas , utilizou-se os índices:

1) Coeficiente de utilização aparente (CUA), para $N$ e $P$, utilizado por Labrecque et al (1995):

$C U A=100(C E T-C E C)$ CEDB $^{-1}$ 
$\mathrm{CET}=$ Conteúdo do Elemento nas árvores em cada Tratamento; $\mathrm{CEC}=$ Conteúdo do Elemento nas árvores do Controle (testemunha); $\mathrm{CEDB}=$ Conteúdo do Elemento no Biossólido administrado em cada tratamento.

2) Eficiência no Uso do Nitrogênio (EUN)= MSP/NE (Larcher, 2000). $\mathrm{MSP}=$ matéria seca produzida

$\mathrm{NE}=$ nitrogênio estocado

3) Coeficiente de Transferência $=M B / M E$

$\mathrm{MB}=$ Metal pesado oriundo do biossólido administrado no tratamento;

$\mathrm{ME}=$ Metal pesado acumulado pela planta no respectivo tratamento; 


\section{RESULTADOS E DISCUSSÃO}

\subsection{Crescimento em altura}

Todas as espécies apresentaram aumento no crescimento em altura como resposta às doses crescentes de biossólido.

Podem-se observar pela Figura 3 as curvas de crescimento da aroeira em função dos diferentes tratamentos. No início do experimento, todas as mudas apresentavam altura semelhante. Aos sessenta e aos cem dias de idade, são observadas curvas de crescimento bastante diferentes, quando se compara a testemunha aos tratamentos com 10 e $20 \mathrm{~g} \mathrm{dm}-3$ de biossólido e com a adubação mineral.

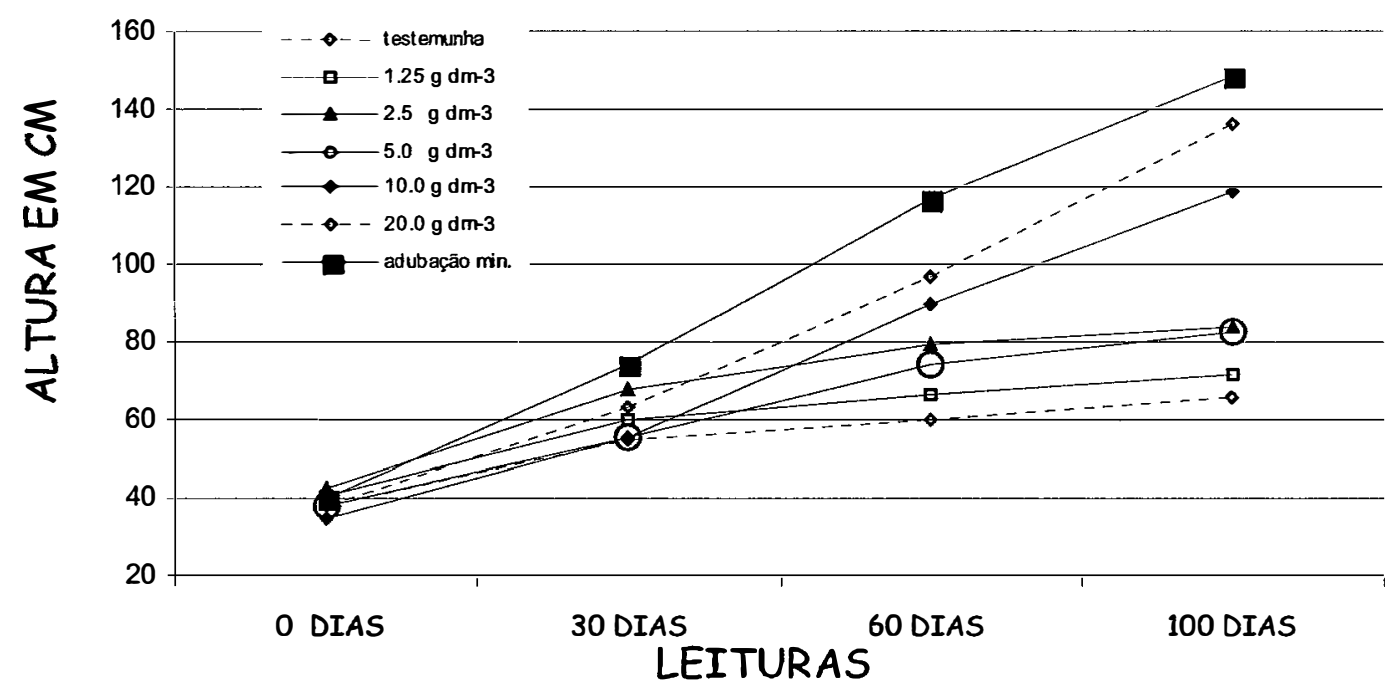

Figura 3 - Valores médios de crescimento em altura das mudas de aroeira cultivadas em potes com doses crescentes de biossólido e com adubação mineral aos 30,60 e 100 dias após o plantio 
Sendo a Aroeira uma espécie pioneira antrópica e de crescimento rápido, esta resposta positiva já era esperada. Neste sentido, Gonçalves et al. (2000)a afirmam que as espécies nativas dos estágios iniciais de sucessão apresentam taxas de crescimento superiores às de final de sucessão e, quanto maiores as taxas de crescimento, maiores as demandas por nutrientes no período imediatamente após o plantio. Isto corrobora os resultados encontrados nesta pesquisa.

A cabreúva, mesmo sendo uma espécie de final de sucessão, com crescimento inicial lento, apresentou respostas diferenciadas para os tratamentos correspondentes a 10 e $20 \mathrm{~g} \mathrm{dm}^{-3}$ de biossólido, quando comparadas à testemunha e à adubação mineral (Figura 4). Isso pode ser explicado pelo fato desta espécie apresentar crescimento naturalmente lento, tanto da parte aérea como do sistema radicular, o qual possibilitaria uma melhor sincronia entre a liberação dos nutrientes, propiciada pela lenta degradação do biossólido, e a capacidade de absorção do sistema radicular. 


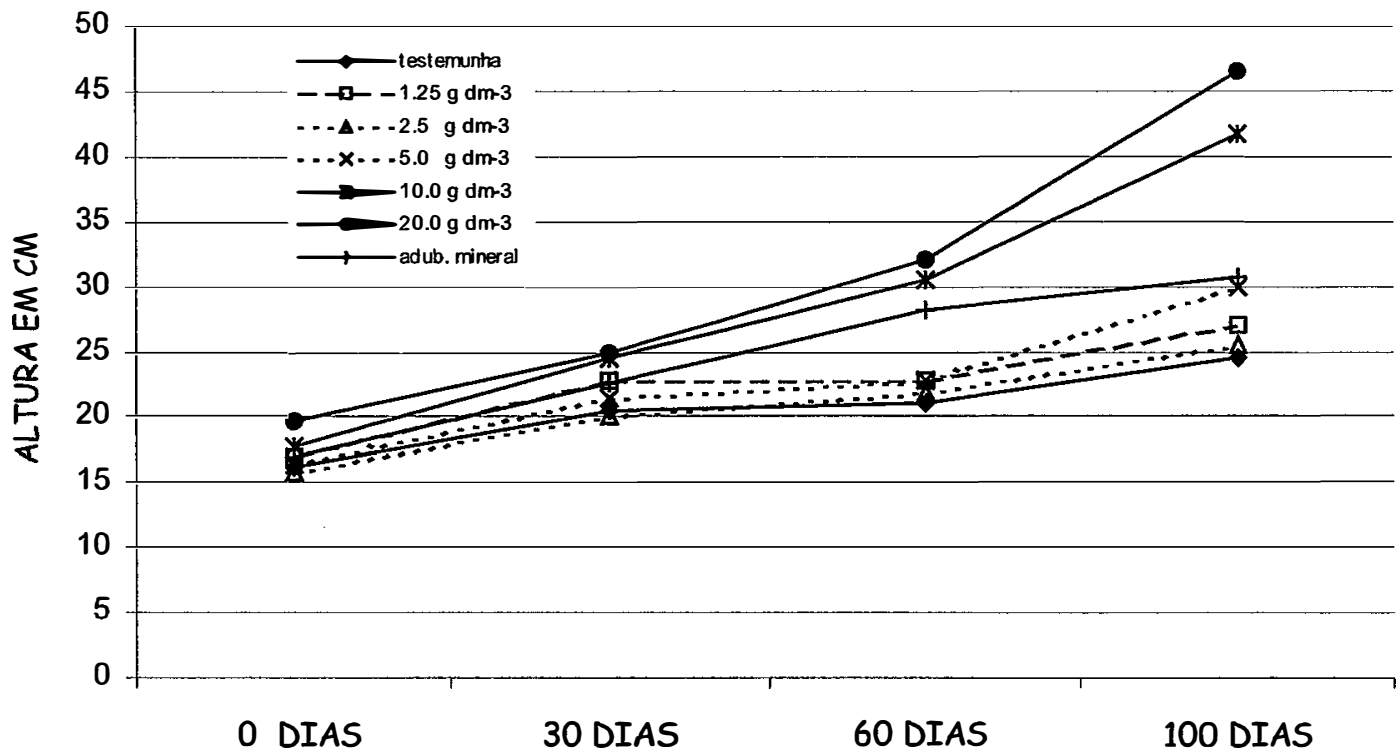

LEITURAS

Figura 4- Valores médios de crescimento em altura das mudas de cabreúva cultivadas em potes com doses crescentes de biossólido e com adubação mineral aos 30,60 e 100 dias após o plantio

O pau-viola apresentou um maior crescimento para o tratamento correspondente à adubação mineral, seguido pela dose com $20 \mathrm{~g} \mathrm{dm}^{-3} \mathrm{de}$ biossólido (Figura 5). 


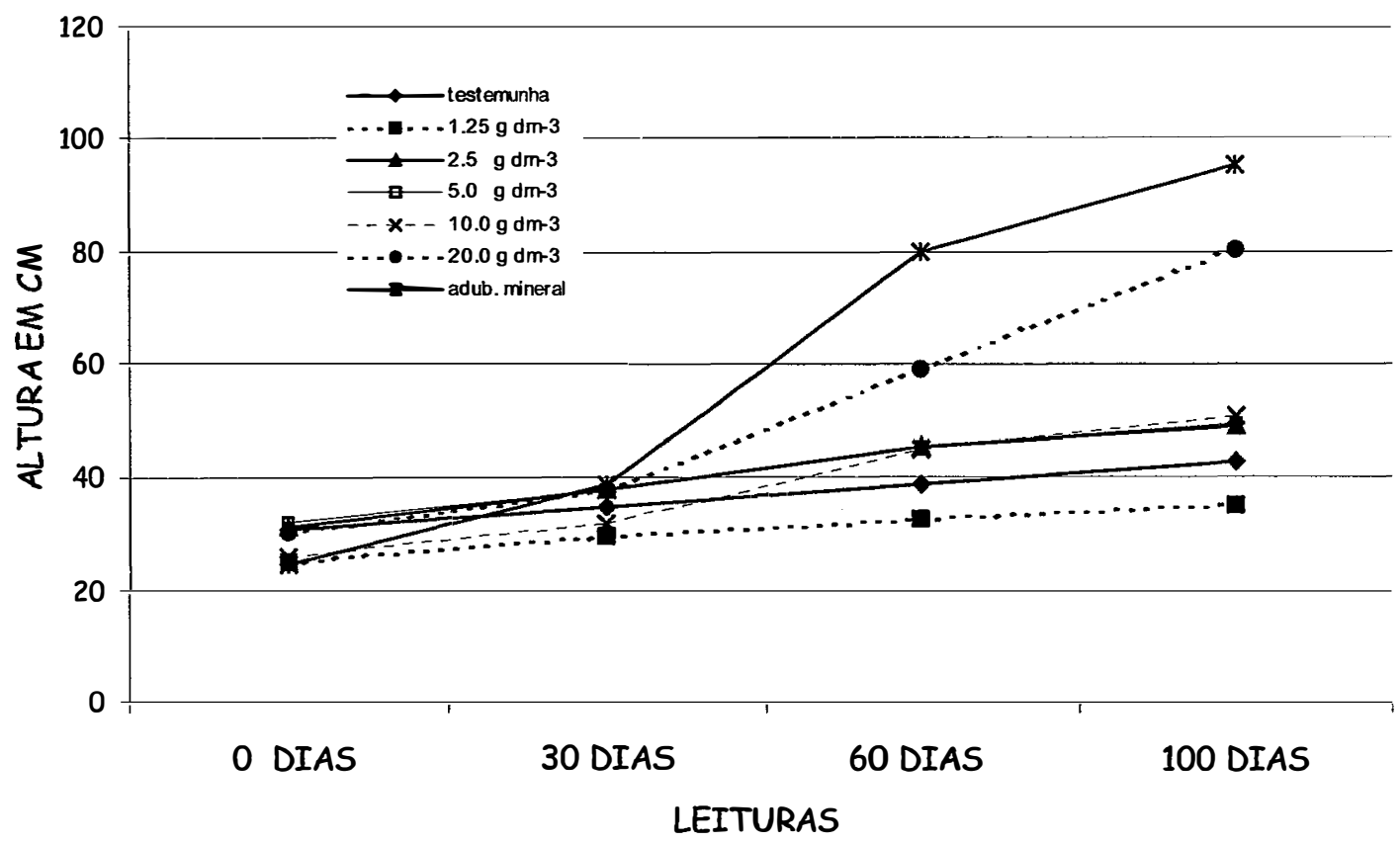

Figura 5 - Valores médios de crescimento em altura das mudas de pau-de-viola cultivadas em potes com doses crescentes de biossólido e com adubação mineral aos 30,60 e 100 dias após o plantio

Por ser esta espécie uma pioneira antrópica de início de sucessão (Lorenzi, 1998), as melhores respostas em crescimento foram obtidas para os tratamentos que disponibilizaram maiores quantidades de nutrientes.

Resultados semelhantes foram obtidos para a unha-de-vaca, também pioneira antrópica, apresentando curvas diferenciadas de crescimento em função da adubação química e das doses crescentes de biossóilido adicionado nos tratamentos (Figura 6). 


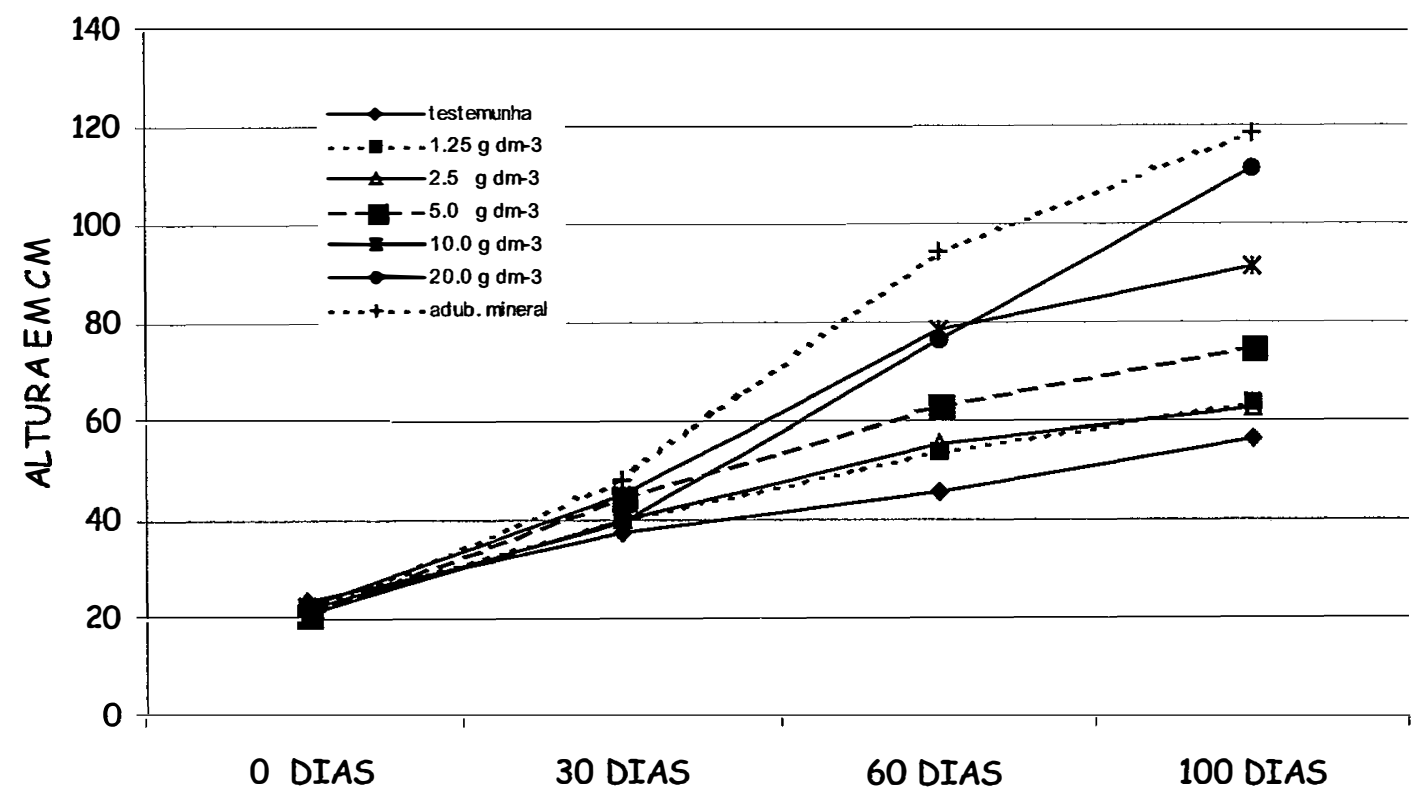

LEITURAS

Figura 6 - Valores médios de crescimento em altura das mudas de unha-devaca cultivadas em potes com doses crescentes de biossólido e com adubação mineral aos 30,60 e 100 dias após o plantio

O incremento médio em altura das quatro espécies, expressando o quanto efetivamente cresceram no período de zero a 100 dias, pode ser observado na Figura 7. Observa-se que à medida que aumentam as dosagens de biossólido, ocorre também o aumento em altura das espécies. Pode-se notar uma aproximação entre as curvas de crescimento da aroeira e da unha-devaca, exibindo valores maiores do que os das demais espécies. Isto pode ser explicado por pertencerem a estágios iniciais de sucessão (pioneiras típicas). 0 pau-viola e a cabreúva, pertencentes a estágios ecológicos mais avançados, exibem curvas de resposta próximas entre si, mas com incrementos menores. Embora o pau-de-viola seja considerado também uma espécie pioneira antrópica, exibiu um comportamento semelhante ao da cabreúva, sugerindo ser uma espécie de fase intermediária de sucessão, ou seja, espécie secundária. Kageyama et al., (1994) classificaram os grupos ecológicos silviculturais em 
"situações" de sucessão antrópica e de sucessão secundária, apontando para uma sucessão diferenciada, principalmente quanto à origem das espécies no início de sucessão. Assim sendo, as pioneiras antrópicas seriam aquelas consideradas não tipicamente pioneiras nas florestas primárias, mas que fazem o papel de pioneiras em áreas degradadas antrópicas. As espécies secundárias/pioneiras antrópicas, espécies secundárias, (normalmente raras na floresta primária), seriam as que fazem o papel de pioneiras em áreas antrópizadas.

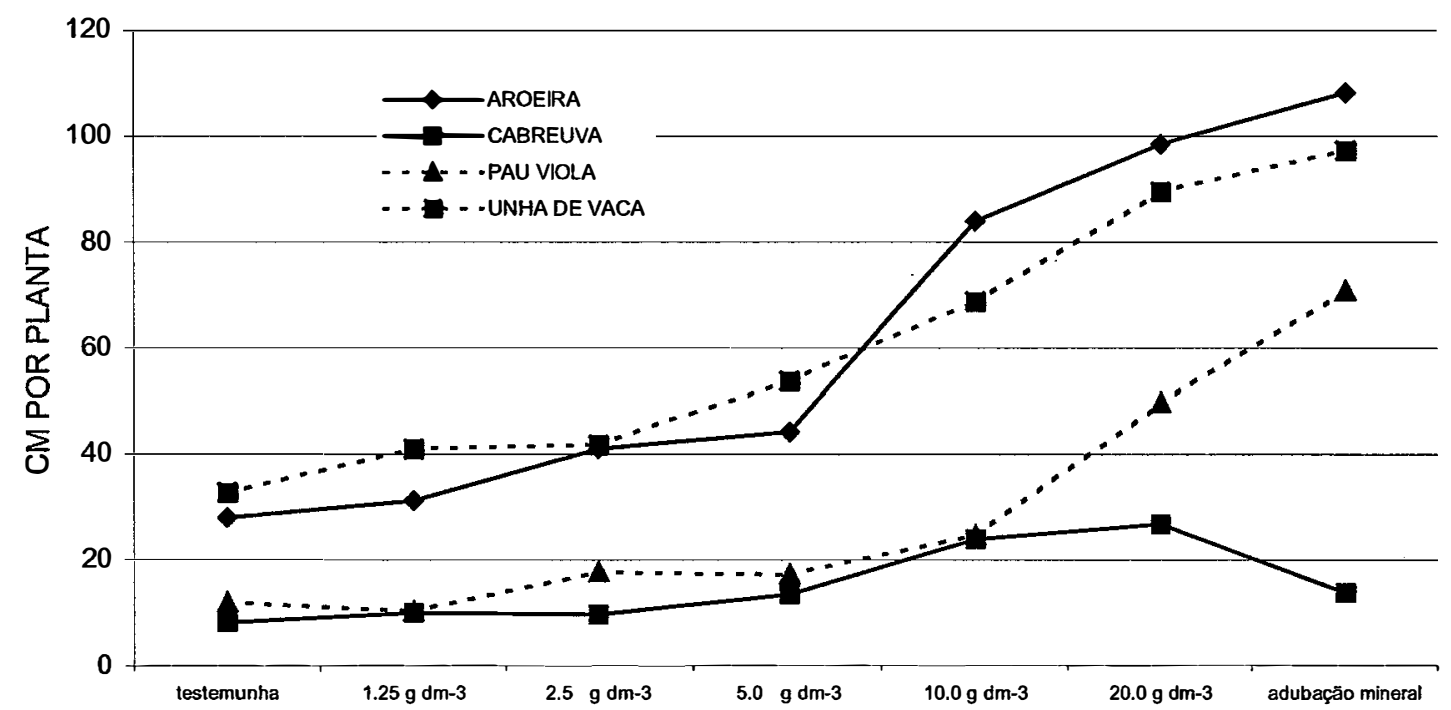

TRATAMENTOS

Figura 7 - Incremento médio em altura (diferença entre a medida inicial no plantio e medida final aos 100 dias) das quatro espécies em função das doses crescentes de biossólido e da adubação mineral

Comparando o incremento médio em altura dentro das quatro espécies, em resposta a cada tratamento (Tabela 8 ), pode-se observar que a aroeira apresentou respostas estatisticamente significativas em relação à testemunha, para os tratamentos correspondentes a $10,20 \mathrm{~g} \mathrm{dm}^{-3} \mathrm{e}$ à adubação mineral, sendo que as respostas aos dois últimos tratamentos foram iguais entre si. A 
cabreúva apresentou respostas positivas para os tratamentos correspondentes a 10 e $20 \mathrm{~g} \mathrm{dm}^{-3}$, mas sem diferenças significativas entre si. A resposta não significativa desta espécie para o tratamento com adubação mineral, em relação à testemunha, pode ser explicada por ser considerada esta espécie como de estágio de final de sucessão, tendo uma menor demanda e uma menor assimilação de nutrientes, mesmo que eles estejam disponiveis.

O pau-de-viola apresentou valores significativos em resposta aos tratamentos correspondentes a $20 \mathrm{~g} \mathrm{dm}^{-3}$ e à adubação mineral. A unha-devaca apresentou valores significativos para os tratamentos com $5,10,20 \mathrm{~g}$ $\mathrm{dm}^{-3}$ e adubação mineral, sendo os dois últimos iguais entre si e maiores do que os dois primeiros.

São observados valores estatisticamente significativos para todas as espécies, com relação à testemunha em resposta aos tratamentos correspondentes às doses de 10 e $20 \mathrm{~g} \mathrm{dm}^{-3}$. A dose de $20 \mathrm{~g} \mathrm{dm}^{-3}$ promoveu resposta igual à adubação mineral para todas as espécies, exceto para a cabreúva, que obteve com a mesma dose, resposta superior à adubação mineral.

Considerando as respostas ao tratamento de $20 \mathrm{~g} \mathrm{dm}^{-3}$, observa-se que a aroeira cresceu em média no período 3,51 vezes, a cabreúva 3,24 vezes, o pau-de-viola 4,10 vezes e a unha-de-vaca 2,73 vezes mais que as respectivas testemunhas. 
Tabela 8. Incremento médio em altura (diferença em $\mathrm{cm}$ entre a medida inicial no plantio e medida final aos 100 dias) dentro das quatro espécies, em função das doses crescentes de biossólido e da adubação mineral

\begin{tabular}{lrrrr}
\hline TRATA & AROEIRA & CABREUVA & PAUVIOLA & UNHA DE VACA \\
\hline testemunha & $28.00 \mathrm{c}$ & $8,25 \mathrm{~b}$ & $12.00 \mathrm{~b}$ & $32,75 \mathrm{c}$ \\
$1.25 \mathrm{~g} \mathrm{dm}^{-3}$ & $31,25 \mathrm{c}$ & $10.00 \mathrm{~b}$ & $10,25 \mathrm{~b}$ & $41.00 \mathrm{c}$ \\
$2.5 \mathrm{~g} \mathrm{dm}^{-3}$ & $41.00 \mathrm{c}$ & $9,75 \mathrm{~b}$ & $17,75 \mathrm{~b}$ & $41,75 \mathrm{c}$ \\
$5.0 \mathrm{~g} \mathrm{dm}^{-3}$ & $44,25 \mathrm{c}$ & $13,50 \mathrm{~b}$ & $17,25 \mathrm{~b}$ & $53,75 \mathrm{~b}$ \\
$10.0 \mathrm{~g} \mathrm{dm}^{-3}$ & $84.00 \mathrm{~b}$ & $24.00 \mathrm{a}$ & $24,75 \mathrm{~b}$ & $68,75 \mathrm{~b}$ \\
$20.0 \mathrm{~g} \mathrm{dm}^{-3}$ & $98,50 \mathrm{a}$ & $26,75 \mathrm{a}$ & $49,75 \mathrm{a}$ & $89,50 \mathrm{a}$ \\
adubação mineral & $108,25 \mathrm{a}$ & $13,75 \mathrm{~b}$ & $70,75 \mathrm{a}$ & $97,25 \mathrm{a}$ \\
\hline
\end{tabular}

Médias acompanhadas da mesma letra não diferem entre si pelo teste Tukey a 5\%.

Ao se comparar o incremento médio em altura entre as espécies e para cada tratamento, observa-se que a aroeira e a unha-de-vaca apresentam valores maiores, mas estatisticamente iguais entre si, indicando pertencerem ao mesmo grupo ecológico de início de sucessão (Tabela 9).

A cabreúva e o pau-de-viola apresentam valores menores, porém iguais entre si, por pertencerem a estágios sucessionais mais avançados, com exceção da resposta da cabreúva à adubação mineral, que foi menor. A diferença de resposta das duas espécies à adubação mineral sugere pertencerem a grupos ecológicos diferentes, sendo a cabreúva de estágio mais avançado, por apresentar menor resposta à adição dos nutrientes prontamente disponíveis no adubo químico.

Tabela 9. Incremento médio em altura (diferença $\mathrm{em} \mathrm{cm}$ entre a medida inicial no plantio e medida final aos 100 dias) entre as quatro espécies, em função das doses crescentes de biossólido e da adubação mineral

\begin{tabular}{|c|c|c|c|c|c|c|c|}
\hline TRATA & TEST & $1.25 \mathrm{~g} \mathrm{dm}^{-3} 2.5$ & $\mathrm{~g} \mathrm{dm}^{-3} 5.0$ & $\mathrm{~g} \mathrm{dm}^{-3}$ & $10.0 \mathrm{~g} \mathrm{dm}^{-3}$ & $20.0 \mathrm{~g} \mathrm{dm}^{-3}$ & adub. Min \\
\hline AROEIRA & $28,00 a$ & $31,25 a$ & $41,00 a$ & $44,25 a$ & $84,00 a$ & $98,50 a$ & $108,25 a$ \\
\hline CABREUVA & $8,25 b$ & $10,00 b$ & $9,75 b$ & $13,50 \mathrm{~b}$ & $24,00 \mathrm{~b}$ & $26,75 b$ & $13,75 c$ \\
\hline PAU VIOLA & $12,00 \mathrm{~b}$ & $10,25 b$ & $17,75 b$ & $17,25 b$ & $24,75 b$ & $49,75 b$ & $70,75 b$ \\
\hline UNHA DE VACA & $32,75 a$ & $41,00 a$ & $41,75 a$ & $53,75 a$ & $68,75 a$ & $89,50 a$ & $97,25 a$ \\
\hline
\end{tabular}
Médias acompanhadas da mesma letra não diferem entre si pelo teste Tukey a $5 \%$.

Pode-se concluir que todas as espécies responderam positivamente em crescimento às doses crescentes de biossólido. $O$ tratamento com $20 \mathrm{~g} \mathrm{dm}^{-3}$ 
promoveu maiores respostas, igualando-se à adubação mineral, podendo portanto substituí-la em cultivos de espécies arbóreas.

Existem grandes diferenças de resposta entre as espécies, distribuídas pelos grupos ecológicos. As de início de sucessão, promoveram maiores incrementos em altura para a maior dosagem de biossólido.

Uma das características importantes de uma espécie para plantio em ambiente público urbano é o seu rápido crescimento e estabelecimento. A aroeira, pau-de-viola e unha-de-vaca mostraram-se mais aptas ao uso na arborização urbana por este aspecto. 


\subsection{Crescimento em diâmetro de colo}

O diâmetro de colo é um parâmetro importante para se avaliar o vigor das mudas, embora ainda não existam padrões para este parâmetro, em função da inexistência de normas específicas para produção de mudas florestais nativas no Brasil.

Pode-se observar pela Figura 8 uma tendência de aumento no diâmetro do colo em função do aumento das doses de biossólido para as espécies aroeira e pau-de-viola. Para as duas outras espécies, não se observa uma tendência evidente de resposta.

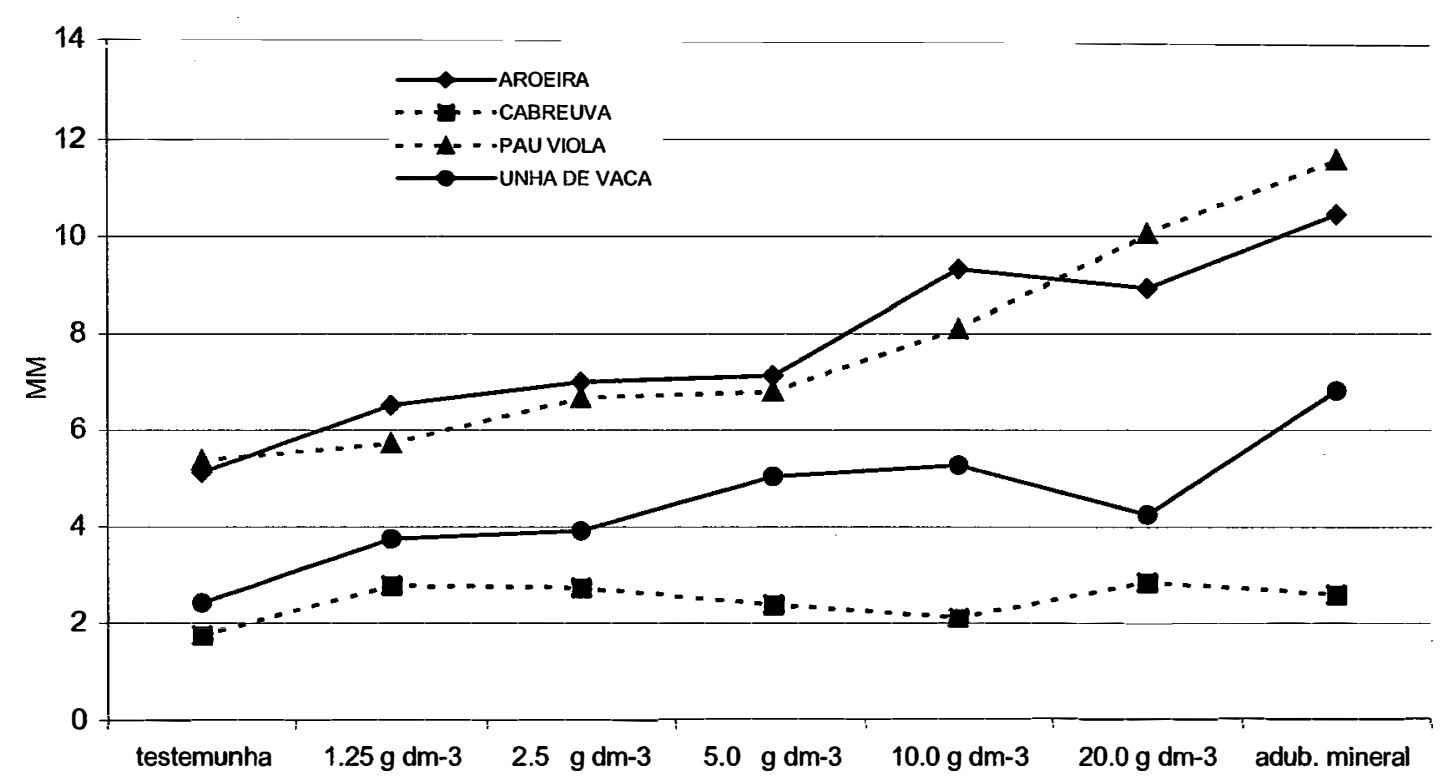

TRATAMENTOS

Figura 8 - Incremento médio em diâmetro de colo em $\mathrm{mm}$ (diferença entre a medida inicial no plantio e medida final aos 100 dias de idade) das quatro espécies, em função das doses crescentes de biossólido e da adubação química

Um parâmetro importante, que deve ser considerado no crescimento inicial das árvores para se avaliar o seu vigor, é a relação de crescimento entre a altura e o diâmetro do caule ( H/D). Sabe-se que apenas um elevado 
crescimento em altura pode indicar o estiolamento das mudas, por estar a luminosidade abaixo do nível exigido, segundo Kramer et al.(1979), que para estas espécies é ainda desconhecido. Até certo ponto, quanto menor esta relação, maior será o vigor da muda, excetuando-se as espécies naturalmente bojudas, ou seja, com diâmetro de colo naturalmente largo, como por exemplo as da família bombacaceae.

Ao analisar-se a Figura 9, pode-se notar uma tendência de aumento desta relação com o aumento das doses de biossólido, indicando que na fase inicial de crescimento, estas espécies investem mais em crescimento em altura do que em diâmetro de caule. Também podemos observar uma tendência de diferenciação entre as espécies quanto a essa relação.

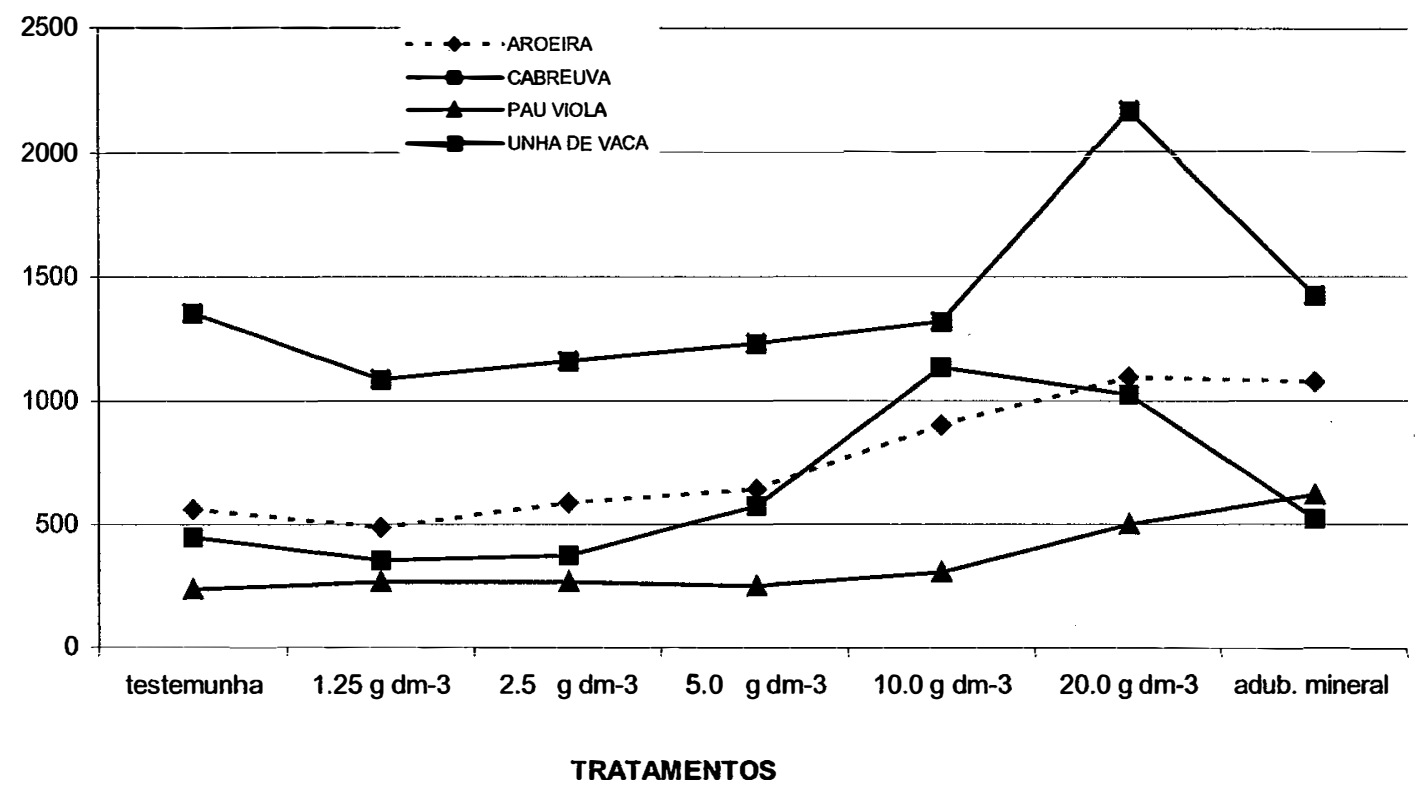

Figura 9 - Relação entre incremento em altura e diâmetro de caule $(H / D)$ das quatro espécies, em função das doses crescentes de biossólido e da adubação mineral

Para a espécie unha-de-vaca, percebe-se uma relação maior entre a altura do caule e o diâmetro do colo, indicando que investiu mais no crescimento em altura do que em diâmetro, nesta fase inicial de crescimento. 
Considerando-se que apenas $18 \%$ da quantidade de luz fotossinteticamente ativa foi interceptada pelo filme que recobre a casa de vegetação e que também não ocorreu sombreamento mútuo entre as plantas utilizadas no experimento, pode-se inferir ser pouco provável ter havido um efeito de estiolamento devido à baixa luminosidade. Pode tratar-se, portanto, de uma característica genética inerente à espécie, ou seja, uma estratégia de desenvolvimento própria da unha-de-vaca que, por pertencer à categoria ecológica das espécies pioneiras, investiria mais acentuadamente no crescimento em altura durante a fase inicial.

Por outro lado, nota-se uma menor relação H/D no pau-de-viola, que por ser espécie secundária, investiu prioritariamente no crescimento inicial do diâmetro do caule para garantir um crescimento posterior em altura.

A cabreúva, por ser uma espécie característica da fase final de sucessão, investiu de forma equilibrada tanto no crescimento em altura como em diâmetro, mantendo proporcionalmente um crescimento global moderado.

A aroeira manteve também uma relação H/D moderada, talvez indicando não ser uma espécie nitidamente pioneira, mas secundária inicial.

De maneira geral, as espécies evidenciam uma maior relação H/D para a dose mais elevada de biossólido $\left(20 \mathrm{~g} \mathrm{dm}^{-3}\right)$. 


\subsection{Produção de matéria seca}

A produção de matéria seca é um parâmetro bastante consistente na avaliação das respostas à adubação em espécies vegetais, complementando os dados de crescimento.

Os resultados obtidos são relativos à matéria seca total da planta, bem como de cada uma de suas partes, como folhas, caule e raízes. É de fundamental importância se analisar não só a produção total de matéria seca, mas a sua alocação na planta, para discutirmos a suas estratégias de crescimento em relação ao seu grupo sucessional e à sua viabilidade de uso na arborização urbana.

Ao se analisar os resultados da Tabela 10, percebe-se que todas as espécies apresentaram resultados estatisticamente significativos às diferentes doses de biossólido em relação à testemunha, excetuando-se os resultados relativos às raízes de cabreúva. Ou seja, todas as espécies apresentaram aumento na produção de matéria seca em suas três partes, em resposta às diferentes doses de biossólido aplicadas, excetuando-se as raízes de cabreúva.

Tabela 10. Resumo das ANOVAs entre tratamentos para os valores de matéria seca de folha, caule e raiz, dentro de cada espécie

\begin{tabular}{lccccc}
\hline $\begin{array}{l}\text { Source of } \\
\text { Variation }\end{array}$ & $\begin{array}{c}\text { Sum of } \\
\text { Squares }\end{array}$ & d.f. & $\begin{array}{c}\text { Mean } \\
\text { Squares }\end{array}$ & $F$ & P \\
\hline $\begin{array}{l}\text { Aroeira }- \text { folha } \\
\text { between }\end{array}$ & 3536. & 6 & 589.3 & 71.43 & $<0.001$ \\
error & 173.2 & 21 & 8.250 & & \\
total & 3709. & 27 & & & \\
Aroeira - caule & & & & & \\
between & $1.4954 \mathrm{E}+04$ & 6 & 2492. & 51.22 & \\
error & 1022. & 21 & 48.66 & & \\
total & $1.5976 \mathrm{E}+04$ & 27 & & & \\
Aroeira - raíz & & & & & \\
between & 1133. & 6 & 188.8 & 35.07 & $<0.001$
\end{tabular}


Tabela 10. Resumo das ANOVAs entre tratamentos para os valores de matéria seca de folha, caule e raiz, dentro de cada espécie

\begin{tabular}{|c|c|c|c|c|c|}
\hline $\begin{array}{l}\text { Source of } \\
\text { Variation }\end{array}$ & $\begin{array}{l}\text { Sum of } \\
\text { Squares }\end{array}$ & d.f. & $\begin{array}{l}\text { Mean } \\
\text { Squares }\end{array}$ & $\mathrm{F}$ & $\mathrm{P}$ \\
\hline error & 113.1 & 21 & 5.384 & & \\
\hline total & 1246. & 27 & & & \\
\hline \multicolumn{6}{|c|}{ Cabreúva - folha } \\
\hline between & 35.60 & 6 & 5.933 & 3.763 & $<0.011$ \\
\hline error & 3.11 & 21 & 1.576 & & \\
\hline total & 68.70 & 27 & & & \\
\hline \multicolumn{6}{|c|}{ Cabreúva - caule } \\
\hline between & 23.99 & 6 & 3.999 & 7.277 & $<0.0003$ \\
\hline error & 11.54 & 21 & 0.5495 & & \\
\hline total & 35.53 & 27 & & & \\
\hline \multicolumn{6}{|c|}{ Cabreúva - raiz } \\
\hline between & 6.268 & 6 & 1.045 & 1.713 & $<0.17$ (NS) \\
\hline error & 12.81 & 21 & 0.6100 & & \\
\hline total & 19.08 & 27 & & & \\
\hline \multicolumn{6}{|c|}{ Pau viola - folhas } \\
\hline between & 894.2 & 6 & 149.0 & 102.8 & $<0.001$ \\
\hline error & 30.44 & 21 & 1.450 & & \\
\hline total & 924.6 & 27 & & & \\
\hline \multicolumn{6}{|c|}{ Pau viola - caule } \\
\hline between & 2562 . & 6 & 427.0 & 55.95 & $<0.001$ \\
\hline error & 160.3 & 21 & 7.632 & & \\
\hline total & 2722 & 27 & & & \\
\hline \multicolumn{4}{|c|}{ Pau viola - raiz } & & $\cdot$ \\
\hline between & 2169 & 6 & 361.5 & 36.42 & $<0.001$ \\
\hline error & 208.4 & 21 & 9.926 & & \\
\hline total & 2378 . & 27 & & & \\
\hline \multicolumn{6}{|c|}{ Unha de vaca - folha } \\
\hline between & 212.4 & 6 & 35.40 & 16.81 & $<0.001$ \\
\hline error & 44.21 & 21 & 2.105 & & \\
\hline total & 256.6 & 27 & & & \\
\hline \multicolumn{6}{|c|}{ Unha de vaca - caule } \\
\hline between & 1234 & 6 & 205.7 & 21.22 & $<0.001$ \\
\hline
\end{tabular}


Tabela 10. Resumo das ANOVAs entre tratamentos para os valores de matéria seca de folha, caule e raiz, dentro de cada espécie

\begin{tabular}{llcccc}
\hline $\begin{array}{l}\text { Source of } \\
\text { Variation }\end{array}$ & $\begin{array}{c}\text { Sum of } \\
\text { Squares }\end{array}$ & d.f. & $\begin{array}{c}\text { Mean } \\
\text { Squares }\end{array}$ & F & P \\
\hline error & 203.5 & 21 & 9.692 & & \\
total & 1438. & 27 & & & \\
Unha de vaca & - raíz & & & & \\
between & 344.4 & 6 & 57.40 & 9.209 & $<0.001$ \\
error & 130.9 & 21 & 6.233 & & \\
total & 475.3 & 27 & & &
\end{tabular}

$\mathrm{P}$ : probabilidade dos resultados assumirem hipótese nula.

Existe forte correlação linear entre aumento de dose de biossólido e produção de matéria seca nas quatro espécies, conforme pode ser observado pela Figura 10.

a) aroeira

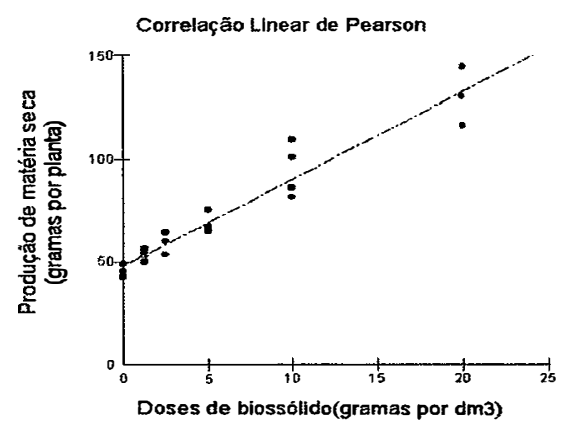

c) pau-de-viola

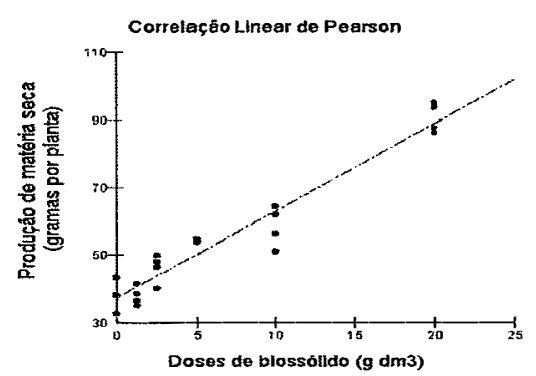

b) cabreúva

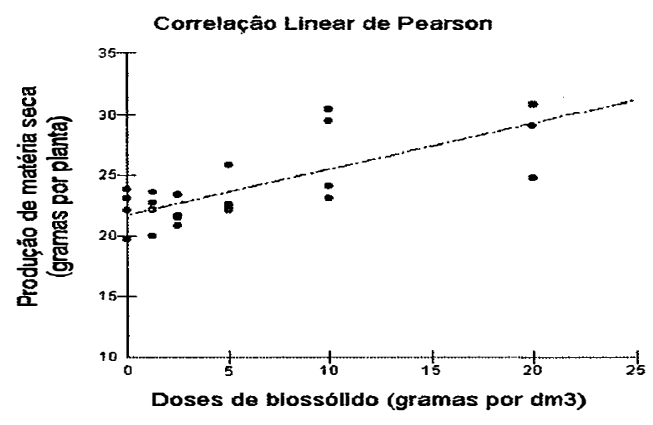

d) unha-de-vaca

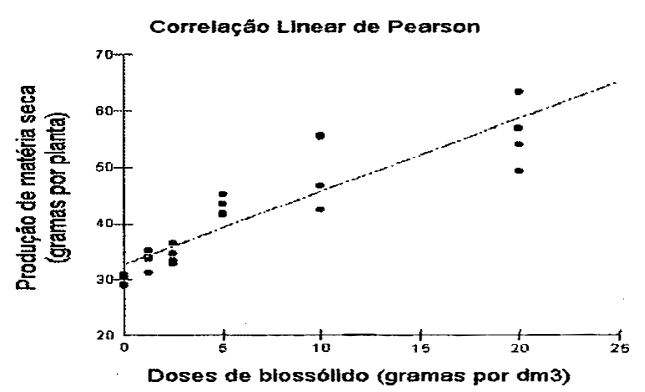

Figura 10- Correlação linear entre doses de biossólido em $\mathrm{g} \mathrm{dm}^{3}$ e produção total de matéria seca em gramas planta ${ }^{-1}$, em função das doses crescentes de biossólido e adubação mineral

$r$ (Person) : aroeira $=0,97$; cabreúva $=0,77$; pau-de-viola $=0,97$; unha-de-vaca $=0,89$ 
A produção total de matéria seca pela aroeira foi significativa para todas as doses de biossólido, comparadas à testemunha. A maior produção foi para o tratamento correspondente a $20 \mathrm{~g} \mathrm{dm}^{3}$, seguida pela aplicação de $10 \mathrm{~g} \mathrm{dm}^{3}$ de biossólido, mas ficaram abaixo da produção total promovida pela adubação mineral (Tabela 11) . Por ser espécie de início de sucessão, caracterizada por um maior crescimento e portanto maior demanda de nutrientes, respondeu melhor às maiores dosagens de nutrientes fornecidas pela adubação mineral. Quando se analisa a locação nos três componentes das plantas, observa-se uma diferenciação de distribuição da matéria seca em cada um dos componentes com relação à distribuição total.

Tabela 11. Produção média de matéria seca (gramas planta ${ }^{-1}$ ) da Aroeira, em função das doses crescentes de biossólido e adubação mineral

\begin{tabular}{lrrrr}
\hline TRATA & FOLHA & CAULE & RAÍZ & TOTAL \\
\hline testemunha & $13,23 \mathrm{c}$ & $17,74 \mathrm{~d}$ & $14,05 \mathrm{~d}$ & $45,03 \mathrm{e}$ \\
$1.25 \mathrm{~g} \mathrm{dm}^{-3}$ & $14,98 \mathrm{c}$ & $22,73 \mathrm{~d}$ & $15,65 \mathrm{~d}$ & $53,37 \mathrm{~d}$ \\
$2.5 \mathrm{~g} \mathrm{dm}^{-3}$ & $16,10 \mathrm{c}$ & $29,41 \mathrm{~d}$ & $15,05 \mathrm{~d}$ & $60,57 \mathrm{~d}$ \\
$5.0 \mathrm{~g} \mathrm{dm}^{-3}$ & $18,92 \mathrm{c}$ & $32,03 \mathrm{~d}$ & $17,33 \mathrm{~d}$ & $68,28 \mathrm{~d}$ \\
$10.0 \mathrm{~g} \mathrm{dm}^{-3}$ & $27,26 \mathrm{~b}$ & $44,36 \mathrm{c}$ & $22,63 \mathrm{c}$ & $94,27 \mathrm{c}$ \\
$20.0 \mathrm{~g} \mathrm{dm}^{-3}$ & $40,29 \mathrm{a}$ & $63,04 \mathrm{~b}$ & $26,94 \mathrm{~b}$ & $130,28 \mathrm{~b}$ \\
adub. mineral & $42,14 \mathrm{a}$ & $87,54 \mathrm{a}$ & $32,00 \mathrm{a}$ & $161,69 \mathrm{a}$ \\
\hline
\end{tabular}

Médias acompanhadas da mesma letra não diferem entre si pelo teste Tukey a 5\%.

A locação nas folhas da matéria seca produzida pela aroeira, foi maior para o tratamento correspondente a $20 \mathrm{~g} \mathrm{dm}^{3}$ de biossólido, que se igualou à da adubação mineral, seguida pela dose de $10 \mathrm{~g} \mathrm{dm}^{3}$ de biossólido. As demais doses não promoveram respostas significativas para a espécie nas folhas, como nas demais partes isoladas.

A produção de matéria seca total na cabreúva mostrou a tendência para uma maior resposta em relação à dosagem correspondente a $20 \mathrm{~g} \mathrm{dm}^{3} \mathrm{de}$ biossólido, que se igualou à produção promovida pela adubação mineral 
(Tabela 12). Por ser espécie de final de sucessão, com crescimento lento e pequena demanda de nutrientes, este comportamento já era esperado.

Tabela 12. Produção média de matéria seca (gramas planta ${ }^{-1}$ ) da cabreúva, em função das doses crescentes de biossólido e adubação mineral

\begin{tabular}{lrrrr}
\hline TRATAMENTO & FOLHA & CAULE & RAíz & TOTAL \\
\hline testemunha & $8.00 \mathrm{~b}$ & $6.91 \mathrm{~b}$ & $7.27 \mathrm{a}$ & $22.18 \mathrm{~b}$ \\
$1.25 \mathrm{~g} \mathrm{dm}^{-3}$ & $8.01 \mathrm{~b}$ & $7.02 \mathrm{~b}$ & $7.04 \mathrm{a}$ & $22.08 \mathrm{~b}$ \\
$2.5 \mathrm{~g} \mathrm{dm}^{-3}$ & $8.00 \mathrm{~b}$ & $6.77 \mathrm{~b}$ & $7.03 \mathrm{a}$ & $21.81 \mathrm{~b}$ \\
$5.0 \mathrm{~g} \mathrm{dm}^{-3}$ & $8.68 \mathrm{~b}$ & $7.38 \mathrm{~b}$ & $7.13 \mathrm{a}$ & $23.20 \mathrm{~b}$ \\
$10.0 \mathrm{~g} \mathrm{dm}^{-3}$ & $9.94 \mathrm{~b}$ & $8.61 \mathrm{ab}$ & $8.20 \mathrm{a}$ & $26.77 \mathrm{~b}$ \\
$20.0 \mathrm{~g} \mathrm{dm}^{-3}$ & $11.17 \mathrm{a}$ & $9.46 \mathrm{a}$ & $8.18 \mathrm{a}$ & $28.82 \mathrm{ab}$ \\
adub. mineral & $8.45 \mathrm{~b}$ & $7.75 \mathrm{~b}$ & $7.43 \mathrm{a}$ & $23.64 \mathrm{ab}$ \\
\hline
\end{tabular}

Médias acompanhadas da mesma letra não diferem entre si pelo teste Tukey a $5 \%$.

Analisando a alocação da produção de matéria seca separadamente nos componentes desta espécie, observam-se diferenças estatísticas em folhas e caules para as doses de $20 \mathrm{~g} \mathrm{dm}^{3}$ de biossólido em relação aos outros tratamentos, inclusive para a adubação mineral. Em raízes, não se observaram diferenças significativas entre os tratamentos.

O pau-de-viola apresentou respostas significativas para produção total de matéria seca para as doses de $5,0 \mathrm{~g} \mathrm{dm}^{3}, 10,0 \mathrm{~g} \mathrm{dm}^{3}, 20 \mathrm{~g} \mathrm{dm}^{3}$ e adubação mineral, sendo as duas últimas doses estatisticamente iguais (tabela 13). A dose de $2,5 \mathrm{~g} \mathrm{dm}^{3}$ apresentou uma tendência a ser maior que a testemunha.

Tabela 13. Produção média de matéria seca (gramas planta $^{-1}$ ) do pau-de-viola, em função das doses crescentes de biossólido e adubação mineral

\begin{tabular}{lrrrr}
\hline TRATA & FOLHA & CAULE & RAIZ & TOTAL \\
\hline testemunha & $9,92 \mathrm{~b}$ & $12,63 \mathrm{c}$ & $15,39 \mathrm{c}$ & $37,95 \mathrm{c}$ \\
$1.25 \mathrm{~g} \mathrm{dm}^{-3}$ & $9,59 \mathrm{~b}$ & $12,37 \mathrm{c}$ & $15,85 \mathrm{c}$ & $37,82 \mathrm{c}$ \\
$2.5 \mathrm{~g} \mathrm{dm}^{-3}$ & $11,27 \mathrm{~b}$ & $15,56 \mathrm{c}$ & $19,21 \mathrm{c}$ & $46,04 \mathrm{bc}$ \\
$5.0 \mathrm{~g} \mathrm{dm}^{-3}$ & $12,38 \mathrm{~b}$ & $17,58 \mathrm{c}$ & $24,39 \mathrm{~b}$ & $54,35 \mathrm{~b}$ \\
$10.0 \mathrm{~g} \mathrm{dm}^{-3}$ & $12,96 \mathrm{~b}$ & $18,98 \mathrm{c}$ & $26,65 \mathrm{~b}$ & $58,6 \mathrm{~b}$ \\
$20.0 \mathrm{~g} \mathrm{dm}^{-3}$ & $22,38 \mathrm{a}$ & $31,56 \mathrm{~b}$ & $36,79 \mathrm{a}$ & $90,73 \mathrm{a}$ \\
adub. mineral & $24,47 \mathrm{a}$ & $39,42 \mathrm{a}$ & $38,82 \mathrm{a}$ & $102,72 \mathrm{a}$ \\
\hline
\end{tabular}

Médias acompanhadas da mesma letra não diferem entre si pelo teste Tukey a $5 \%$. 
Quando se analisa a alocação da matéria seca produzida nos três componentes das plantas, observa-se que na parte aérea houve maior alocação em resposta às doses de $20 \mathrm{~g} \mathrm{dm}^{3}$ e à adubação mineral, sendo que os resultados foram estatisticamente iguais para as folhas e para caule e a maior resposta foi para a adubação mineral. Para as raízes, houve uma alocação de matéria seca significativamente maior para as doses de $5,0 \mathrm{~g} \mathrm{dm}^{3}$, $10,0 \mathrm{~g} \mathrm{dm}^{3}, \quad 20 \mathrm{~g} \mathrm{dm}^{3}$ e adubação mineral, o que pode ser explicado por tratar-se de espécie secundária, investindo em raízes, como estratégia de sobrevivência e para ser mais competitiva no futuro.

A unha-de-vaca apresentou maior produção total de matéria seca para os tratamentos com $20 \mathrm{~g} \mathrm{dm}^{3}$ e adubação mineral, sendo estes iguais entre si (Tabela 14). A resposta à dose de $5,0 \mathrm{~g} \mathrm{dm}^{3}$ de biossólido apresentou uma tendência a ser maior do que a testemunha. A distribuição nas três partes das plantas separadamente mostrou a mesma proporcionalidade que a distribuição na planta toda, exceto para a dosagem de $5,0 \mathrm{~g} \mathrm{dm}^{3}$, que apresentou diferenças significativas para as raízes, o que pode ser explicado por ser uma leguminosa.

Tabela 14. Produção média de matéria seca $\left(\right.$ gramas $_{\text {planta }}{ }^{-1}$ ) da unha-de-vaca, em função da aplicação de doses crescentes de biossólido e adubação mineral

\begin{tabular}{lrrrr}
\hline TRATAMENTO & FOLHA & CAULE & RAIZ & TOTAL \\
\hline testemunha & $8,48 \mathrm{c}$ & $9,14 \mathrm{c}$ & $12,16 \mathrm{~b}$ & $29.79 \mathrm{c}$ \\
$1.25 \mathrm{~g} \mathrm{dm}^{-3}$ & $9,16 \mathrm{c}$ & $10,61 \mathrm{c}$ & $13,77 \mathrm{~b}$ & $33.55 \mathrm{c}$ \\
$2.5 \mathrm{~g} \mathrm{dm}^{-3}$ & $9,67 \mathrm{c}$ & $10,89 \mathrm{c}$ & $13,77 \mathrm{~b}$ & $34.34 \mathrm{c}$ \\
$5.0 \mathrm{~g} \mathrm{dm}^{-3}$ & $11,12 \mathrm{c}$ & $13,89 \mathrm{c}$ & $17,97 \mathrm{a}$ & $42.99 \mathrm{c}$ \\
$10.0 \mathrm{~g} \mathrm{dm}^{-3}$ & $12,06 \mathrm{~b}$ & $17,22 \mathrm{~b}$ & $20,81 \mathrm{a}$ & $50.10 \mathrm{ab}$ \\
$20.0 \mathrm{~g} \mathrm{dm}^{-3}$ & $15,09 \mathrm{a}$ & $22,33 \mathrm{a}$ & $18,47 \mathrm{a}$ & $55.90 \mathrm{a}$ \\
adub. mineral & $16,19 \mathrm{a}$ & $28,66 \mathrm{a}$ & $21,92 \mathrm{a}$ & $66.78 \mathrm{a}$ \\
\hline
\end{tabular}

Médias acompanhadas da mesma letra não diferem entre si pelo teste Tukey a $5 \%$. 
Quando se compara a produção de matéria seca entre as espécies, pode-se observar pela Tabela 15 que as espécies de início de sucessão apresentaram uma produção muito maior que a de final de sucessão.

Tabela 15. Produção média de matéria seca (gramas planta ${ }^{-1}$ ) entre as quatro espécies, em função da aplicação de doses crescentes de biossólido e adubação mineral

\begin{tabular}{lrrrr}
\hline ESPÉCIES & $1.25 \mathrm{~g} \mathrm{dm}^{-3}$ & $5.0 \mathrm{~g} \mathrm{dm}^{-3}$ & $20.0 \mathrm{~g} \mathrm{dm}^{-3}$ & AD. MINERAL \\
\hline AROEIRA & $53.37 \mathrm{a}$ & $68.29 \mathrm{a}$ & $130.28 \mathrm{a}$ & $161.69 \mathrm{a}$ \\
CABREUVA & $22.08 \mathrm{c}$ & $23.20 \mathrm{c}$ & $28.82 \mathrm{~d}$ & $23.64 \mathrm{~d}$ \\
PAU DE VIOLA & $37.82 \mathrm{~b}$ & $54.35 \mathrm{~b}$ & $90.73 \mathrm{~b}$ & $102.72 \mathrm{~b}$ \\
UNHA DE VACA & $33.55 \mathrm{~b}$ & $42.99 \mathrm{~b}$ & $55.89 \mathrm{c}$ & $66.78 \mathrm{c}$ \\
\hline
\end{tabular}

Médias acompanhadas da mesma letra não diferem entre si pelo teste Tukey a $5 \%$.

A relação da produção de matéria seca entre a parte aérea e as raízes pode evidenciar a estratégia de alocação de cada espécie e pode servir como indicativo do estágio sucessional de cada uma delas.

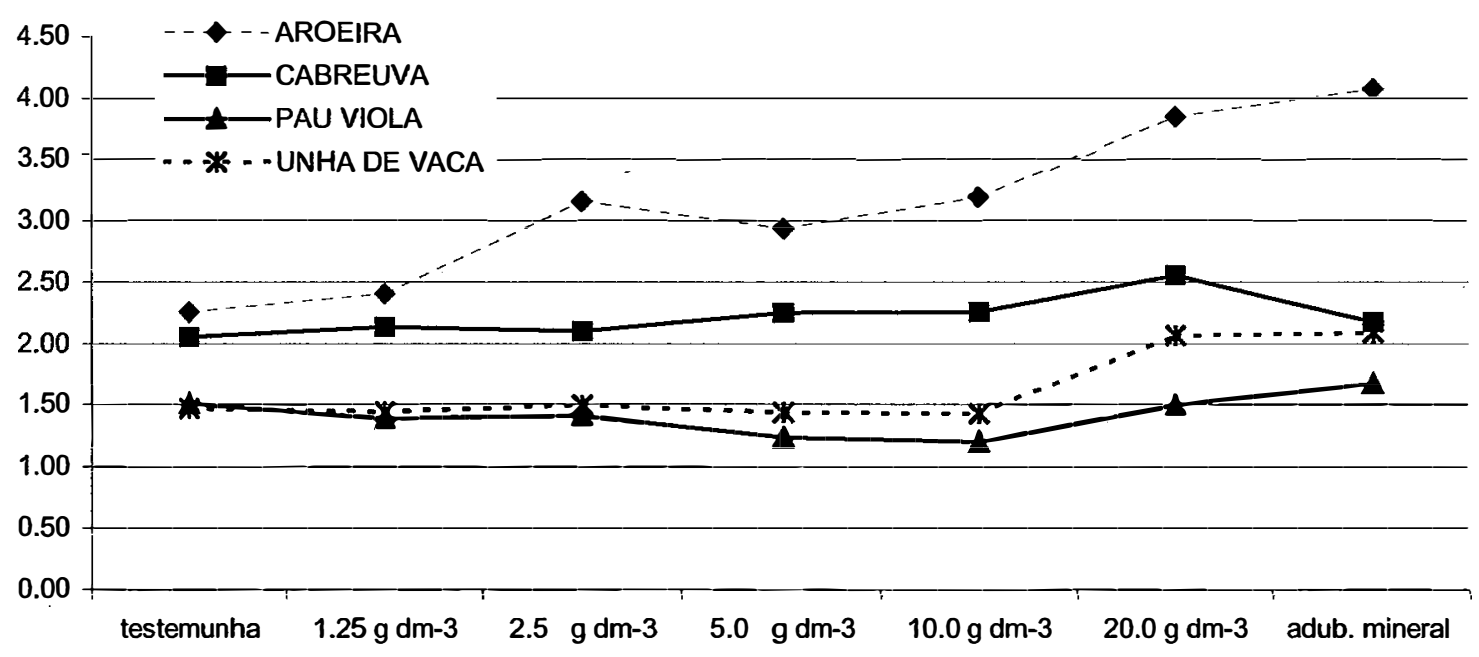

TRATAMENTOS

Figura 11 - Relação entre a alocação de matéria seca na parte aérea e na raiz das quatro espécies, em função das doses crescentes de biossólido e da adubação mineral 
O aumento das doses de biossólido, pela maior disponibilidade de nutrientes por volume de solo, promove uma tendência de maior alocação de matéria seca na parte aérea em detrimento do sistema radicular.

Percebe-se, pela Figura 11, uma tendência do pau-de-viola apresentar menores valores, significando ter investido mais no crescimento das raízes, por ser esta espécie de fase sucessional intermediária. A unha-de-vaca, embora seja uma espécie de início de sucessão, também apresentou estratégia semelhante, investindo mais em raizes, o que pode ser explicado por ser uma leguminosa e apresentar simbiose no sistema radicular com certas bactérias capazes de fixar o nitrogênio do ar (Rhizobium). A cabreúva apresentou uma relação intermediária entre as espécies, indicando maior proporcionalidade entre as alocações em parte aérea e raiz, por ser espécie de final de sucessão. A aroeira apresentou uma maior tendência para a alocação de matéria seca na parte aérea das plantas por ser de início de sucessão.

O tratamento com $20 \mathrm{~g} \mathrm{dm}^{-3}$ aumentou a produção total de matéria seca na aroeira, pau-de-viola e unha de vaca, promovendo uma tendência a aumento na cabreúva. Promoveu uma produção de matéria seca semelhante à adubação mineral. Assim, a dose de $20 \mathrm{~g} \mathrm{dm}^{-3}$ de biossólido pode substituir a adubação mineral no cultivo de mudas de espécies nativas em potes. 


\subsection{Avaliação do estado nutricional}

\subsubsection{Nitrogênio}

A análise das concentrações e dos estoques de nutrientes nos tecidos vegetais das quatro espécies estudadas é de fundamental importância para a avaliação do seu estado nutricional em resposta às doses crescentes de biossólido e da adubação química.

As concentrações de nitrogênio em função dos diferentes tratamentos somente foram significativas para folhas de aroeira, como pode ser visto pela Tabela 16 . Por ser a aroeira uma espécie pioneira de rápido crescimento e de grande demanda por nutrientes, a espécie concentrou mais nitrogênio nas folhas em resposta a todos os tratamentos com relação à testemunha.

Tabela 16.Resumo dos resultados das ANOVAS entre tratamentos para concentrações de nitrogênio e fósforo nas folhas e raízes das quatro espécies, em função de aplicação de doses crescentes de biossólido e adubação mineral

\begin{tabular}{|c|c|c|c|c|c|}
\hline $\begin{array}{l}\text { Source of } \\
\text { Variation }\end{array}$ & $\begin{array}{l}\text { Sum of } \\
\text { Squares }\end{array}$ & d.f. & $\begin{array}{l}\text { Mean } \\
\text { Squares }\end{array}$ & $\mathrm{F}$ & $\mathrm{P}$ \\
\hline \multicolumn{6}{|l|}{ NITROGÊNIO } \\
\hline \multicolumn{6}{|c|}{ Aroeira - folha } \\
\hline between & 75.29 & 4 & 18.82 & 8.347 & 0.0009 \\
\hline error & 33.82 & 15 & 2.255 & & \\
\hline total & 109.1 & 19 & & & \\
\hline \multicolumn{6}{|c|}{ Cabreúva - folha } \\
\hline between & 146.6 & 4 & 36.65 & 2.644 & 0.075 (ns) \\
\hline error & 207.9 & 15 & 13.86 & & \\
\hline total & 354.5 & 19 & & & \\
\hline \multicolumn{6}{|c|}{ Pau-de-viola - folha } \\
\hline between & 29.89 & 4 & 7.473 & 1.516 & 0.25 (ns) \\
\hline error & 73.93 & 15 & 4.929 & & \\
\hline total & 103.8 & 19 & & & \\
\hline \multicolumn{6}{|c|}{ Unha-de-vaca - folha } \\
\hline between & 195.4 & 4 & 48.84 & 2.271 & 0.11 (ns) \\
\hline error & 322.6 & 15 & 21.51 & 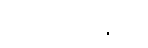 & \\
\hline total & 518.0 & 19 & & & \\
\hline \multicolumn{6}{|c|}{ Aroeira - raíz $-\mathrm{N}$} \\
\hline between & 32.12 & 4 & 8.030 & 0.9047 & 0.49 (ns) \\
\hline error & 133.1 & 15 & 8.876 & & \\
\hline total & 165.3 & 19 & & & . \\
\hline \multicolumn{6}{|l|}{ Cabreuva raíz } \\
\hline between & 65.42 & 4 & 16.35 & 4.457 & 0.014 (ns) \\
\hline error & 55.04 & 15 & 3.669 & & \\
\hline total & 120.5 & 19 & & & \\
\hline
\end{tabular}


Tabela 16.Resumo dos resultados das ANOVAS entre tratamentos para concentrações de nitrogênio e fósforo nas folhas e raízes das quatro espécies, em função de aplicação de doses crescentes de biossólido e adubação mineral

\begin{tabular}{|c|c|c|c|c|c|}
\hline $\begin{array}{l}\text { Source of } \\
\text { Variation }\end{array}$ & $\begin{array}{l}\text { Sum of } \\
\text { Squares }\end{array}$ & d.f. & $\begin{array}{l}\text { Mean } \\
\text { Squares }\end{array}$ & F & $\mathrm{P}$ \\
\hline \multicolumn{6}{|c|}{ Pau-de-viola - raíz } \\
\hline between & 15.13 & 4 & 3.783 & 1.108 & $0.39(\mathrm{~ns})$ \\
\hline error & 51.23 & 15 & 3.415 & & \\
\hline total & 66.37 & 19 & & & \\
\hline \multicolumn{6}{|c|}{ Unha-de-vaca - raiz } \\
\hline between & 77.89 & 4 & 19.47 & 2.676 & $0.073(\mathrm{~ns})$ \\
\hline error & 109.1 & 15 & 7.276 & & \\
\hline total & 187.0 & 19 & & & \\
\hline \multicolumn{6}{|c|}{ FÓSFORO } \\
\hline \multicolumn{6}{|c|}{ Aroeira - folha } \\
\hline between & 9700 & 4 & 2425 & 12.37 & 0.0001 \\
\hline error & 2940 & 15 & 196.0 & & \\
\hline total & 12.640 & 19 & & & \\
\hline \multicolumn{6}{|c|}{ Cabreuva - folha } \\
\hline between. & 9.4538 & 4 & 2.363 & 17.48 & 0.0001 \\
\hline error & 2.0281 & 15 & 1.352 & & \\
\hline total & 1.1482 & 19 & & & \\
\hline \multicolumn{6}{|c|}{ Pau-de-viola - folha } \\
\hline between & 1.105 & 4 & 2764 . & 5.33 & 0.0071 \\
\hline error & 7773. & 15 & 518.2 & & \\
\hline total & 1.8829 & 19 & & & \\
\hline \multicolumn{6}{|c|}{ Unha-de-vaca - folha } \\
\hline between & 2.296 & 4 & 5742 . & 10.71 & 0.0003 \\
\hline error & 8039. & 15 & 535.9 & & \\
\hline total & 3.1006 & 19 & & & \\
\hline \multicolumn{6}{|c|}{ Aroeira - raiz } \\
\hline between & 1.791 & 4 & 4479 . & 6.466 & 0.0031 \\
\hline error & 1.039 & 15 & 692.7 & & \\
\hline total & 2.830 & 19 & & & \\
\hline \multicolumn{6}{|c|}{ Cabreuva - Raiz } \\
\hline between & 1.731 & 4 & 4328 & 2.658 & $0.074(\mathrm{~ns})$ \\
\hline error & 2.442 & 15 & 1628 . & & \\
\hline total & 4.173 & 19 & & & \\
\hline \multicolumn{6}{|c|}{ Pau-de-viola - Raiz } \\
\hline between & 6.083 & 4 & 1.520 & 19.49 & 0.0001 \\
\hline error & 1.170 & 15 & 780.2 & & \\
\hline total & 7.253 & 19 & & & \\
\hline \multicolumn{6}{|c|}{ Unha-de-vaca - Raiz } \\
\hline between & 7.997 & 4 & 1.999 & 18.69 & 0.0001 \\
\hline error & 1.604 & 15 & 1070 & & \\
\hline total & 9.602 & 19 & & & \\
\hline
\end{tabular}


Percebe-se, pela Tabela 17 , que houve uma tendência de uma maior concentração de nitrogênio nas raízes da aroeira para os tratamentos com maiores doses de biossólido e de adubação mineral, embora não haja diferenças estatisticamente significativas.

Para a cabreúva e unha-de-vaca, verificou-se também uma tendência de aumento da concentração de nitrogênio tanto nas folhas quanto nas raízes, com o aumento das doses de biossólido. Para o pau-de-viola, observa-se uma tendência de aumento de concentração de nitrogênio somente nas folhas.

Tabela 17. Concentrações médias de nitrogênio $\left(\mathrm{g} \mathrm{kg}^{-1}\right)$ nas folhas e raízes das quatro espécies, em função das doses crescentes de biossólido e adubação mineral

\begin{tabular}{lrrrrrrrr}
\hline \multirow{2}{*}{ TRATAMENTO } & \multicolumn{2}{c}{ AROEIRA } & \multicolumn{2}{c}{ CABREUVA } & \multicolumn{2}{c}{ PAU DE VIOLA } & \multicolumn{2}{c}{ UNHA-DE-VACA } \\
\cline { 2 - 8 } & FOLHA & RAIZ & FOLHA & RAIZ & FOLHA & RAIZ & FOLHA & RAIZ \\
\hline TESTEMUNHA & $9,97 \mathrm{~b}$ & $6,65 a$ & $16,72 a$ & $9,77 a$ & $10,77 a$ & $9,30 a$ & $18,65 a$ & $14,25 a$ \\
$1.25 \mathrm{~g} \mathrm{dm}^{-3}$ & $14,22 a$ & $6.70 a$ & $22,52 a$ & $10,85 a$ & $13,07 a$ & $11,32 a$ & $18,65 a$ & $12,75 a$ \\
$5.0 \mathrm{~g} \mathrm{dm}^{-3}$ & $13,70 a$ & $7,07 a$ & $22,35 a$ & $11,57 a$ & $12,60 a$ & $10,52 a$ & $19,00 a$ & $14,05 a$ \\
$20.0 \mathrm{~g} \mathrm{dm}^{-3}$ & $15,85 a$ & $8,20 a$ & $24,37 a$ & $14,67 a$ & $13,35 a$ & $11,87 a$ & $21,67 a$ & $18,60 a$ \\
AD. MINERAL & $12,80 a$ & $10.00 a$ & $23,67 a$ & $13,67 a$ & $14,52 a$ & $10,55 a$ & $26,77 a$ & $15,05 a$ \\
\hline
\end{tabular}

Médias acompanhadas da mesma letra não diferem entre si pelo teste Tukey a $5 \%$.

A concentração de nitrogênio em tecidos vegetais varia de 1 a $5 \%$ na matéria seca, segundo Sarruge \& Haag (1974). Tomando como base de referência, todas as concentrações encontradas nos tratamentos, inclusive nos tecidos das plantas testemunhas, estão dentro deste intervalo, não demonstrando deficiência deste nutriente.

Gonçalves et al. (1992), de forma mais específica, estudando espécies florestais nativas, verificaram ampla variação entre espécies de diferentes grupos sucessionais na concentração e acumulação de nutrientes em condições de viveiro e de campo. Observaram, em viveiro, concentrações médias de nitrogênio na parte aérea das espécies pioneiras de $17 \mathrm{~g} \mathrm{~kg}^{-1}$, nas secundárias de $13 \mathrm{~g} \mathrm{~kg}^{-1}$ e de $10 \mathrm{~g} \mathrm{~kg}^{-1}$, nas clímax, em plantas com 130 dias, 
160 dias e 210 dias de idade e alturas médias de $34 \mathrm{~cm}, 29 \mathrm{~cm}$ e $27 \mathrm{~cm}$ respectivamente.

Pode-se observar, pela Tabela 18 , valores de concentração de nitrogênio nas folhas das quatro espécies, em resposta às doses crescentes de biossólido e adubação química entre 12,6 e $24,37 \mathrm{~g} \mathrm{~kg}^{-1}$, portanto próximas às encontradas por Gonçalves et al. (1992). Embora sendo espécie de final de sucessão, a cabreúva foi a que mais concentrou nitrogênio em resposta a todos os tratamentos, seguida pela unha-de-vaca, que é espécie pioneira. As outras duas espécies concentraram nitrogênio de forma semelhante, por serem de início de sucessão, embora a aroeira seja considerada uma espécie pioneira e o pau-de-viola, uma espécie secundária inicial. Assim sendo, não se confirmou o observado por Gonçalves et al. (1992), o que pode ser explicado pelo efeito de diluição, uma vez que as quatro espécies apresentaram produções de matéria seca muito distintas.

Tabela 18 .Concentrações médias de nitrogênio $\left(\mathrm{g} \mathrm{kg}^{-1}\right)$ nas folhas entre as quatro espécies, em função das doses crescentes de biossólido e adubação mineral

\begin{tabular}{|c|c|c|c|c|}
\hline ESPÉCIES & $1.25 \mathrm{~g} \mathrm{dm}^{-3}$ & $5.0 \mathrm{~g} \mathrm{dm}^{-3}$ & $20.0 \mathrm{~g} \mathrm{dm}^{-3}$ & AD. MINERAL \\
\hline AROEIRA & $14.22 b$ & $13.70 \mathrm{c}$ & $15.85 b$ & $12.80 \mathrm{~b}$ \\
\hline CABREUVA & $22.52 a$ & $22.35 a$ & $24.37 a$ & $23.67 a$ \\
\hline PAU DE VIOLA & $13.07 b$ & $21260 c$ & $13.35 b$ & $14.52 b$ \\
\hline UNHA-DE-VACA & $18.65 b$ & $19.00 \mathrm{~b}$ & $21.67 a$ & $26.77 a$ \\
\hline
\end{tabular}

Médias acompanhadas da mesma letra não diferem entre si pelo teste Tukey a 5\%.

O estoque de nutrientes é a quantidade acumulada na matéria seca da planta toda ou de seus compartimentos separadamente (folhas, caules, raízes). Ao se analisar a Tabela 19 , pode-se observar diferenças significativas para estoque de nitrogênio em resposta à dosagem de $20,0 \mathrm{~g} \mathrm{dm}^{-3}$ comparada à testemunha, nas folhas de mudas da aroeira, cabreúva, pau-de-viola e uma tendência para a unha-de-vaca. Também se observa uma tendência a maior estoque na aroeira em resposta a dose de $5 \mathrm{~g} \mathrm{dm}^{-3}$ de biossólido por ser esta 
espécie pioneira. As respostas ao tratamento de $20,0 \mathrm{~g} \mathrm{dm}^{-3}$ e adubação mineral foram estatisticamente iguais, exceto para a cabreúva, que estocou menos em resposta à adubação mineral, o que pode ser explicado por ser espécie de final de sucessão, tendo crescimento e assimilação de nutrientes mais lenta, aproveitando melhor o nitrogênio fornecido mais lentamente pelo biossólido. Portanto, ao se analisar o estoque de nutrientes, confirma-se o efeito da diluição do nitrogênio nas espécies que produziram maiores quantidades de matéria seca.

Tabela 19 . Estoque de nitrogênio (g planta $\left.{ }^{-1}\right)$ nas folhas das quatro espécies, em função das doses crescentes de biossólido e adubação mineral

\begin{tabular}{lrrrr}
\hline TRATA & AROEIRA & CABREUVA & PAU VIOLA & UNHA VACA \\
\hline TESTEMUNHA & $0.13 \mathrm{~b}$ & $0.13 \mathrm{~b}$ & $0.11 \mathrm{~b}$ & $0.16 \mathrm{~b}$ \\
$1.25 \mathrm{~g} \mathrm{dm}^{-3}$ & $0.21 \mathrm{~b}$ & $0.17 \mathrm{~b}$ & $0.13 \mathrm{~b}$ & $0.17 \mathrm{~b}$ \\
$5.0 \mathrm{~g} \mathrm{dm}^{-3}$ & $0.26 \mathrm{ab}$ & $0.19 \mathrm{~b}$ & $0.16 \mathrm{~b}$ & $0.21 \mathrm{~b}$ \\
$20.0 \mathrm{~g} \mathrm{dm}^{-3}$ & $0.26 \mathrm{a}$ & $0.28 \mathrm{a}$ & $0.30 \mathrm{a}$ & $0.33 \mathrm{ab}$ \\
AD. MINERAL & $0.26 \mathrm{a}$ & $0.20 \mathrm{~b}$ & $0.35 \mathrm{a}$ & $0.44 \mathrm{a}$ \\
\hline
\end{tabular}

Médias acompanhadas da mesma letra não diferem entre si pelo teste Tukey a 5\%.

O estoque de nutrientes nos caules tende a ser menor que em folhas e raízes das espécies arbóreas conhecidas, como pinheiros e eucaliptos. Também em espécies nativas o estoque é muito menor. Quando se observa a Figura12, nota-se que o estoque máximo de nitrogênio em caule promovido pelas maiores dosagens de biossólido e adubação mineral fica próximo ao estoque promovido pelas menores doses de biossólido e adubação mineral em folhas. O aumento das doses de biossólido foi acompanhado pela tendência de aumento do estoque nas quatro espécies, sendo que no tratamento com $20 \mathrm{~g}$ $\mathrm{dm}^{-3}$ de biossólido a aroeira evidenciou um maior acúmulo de nitrogênio, seguida pelo pau-viola e unha-de-vaca, sendo a cabreúva a espécie que menos acumulou, por ser de final de sucessão. 


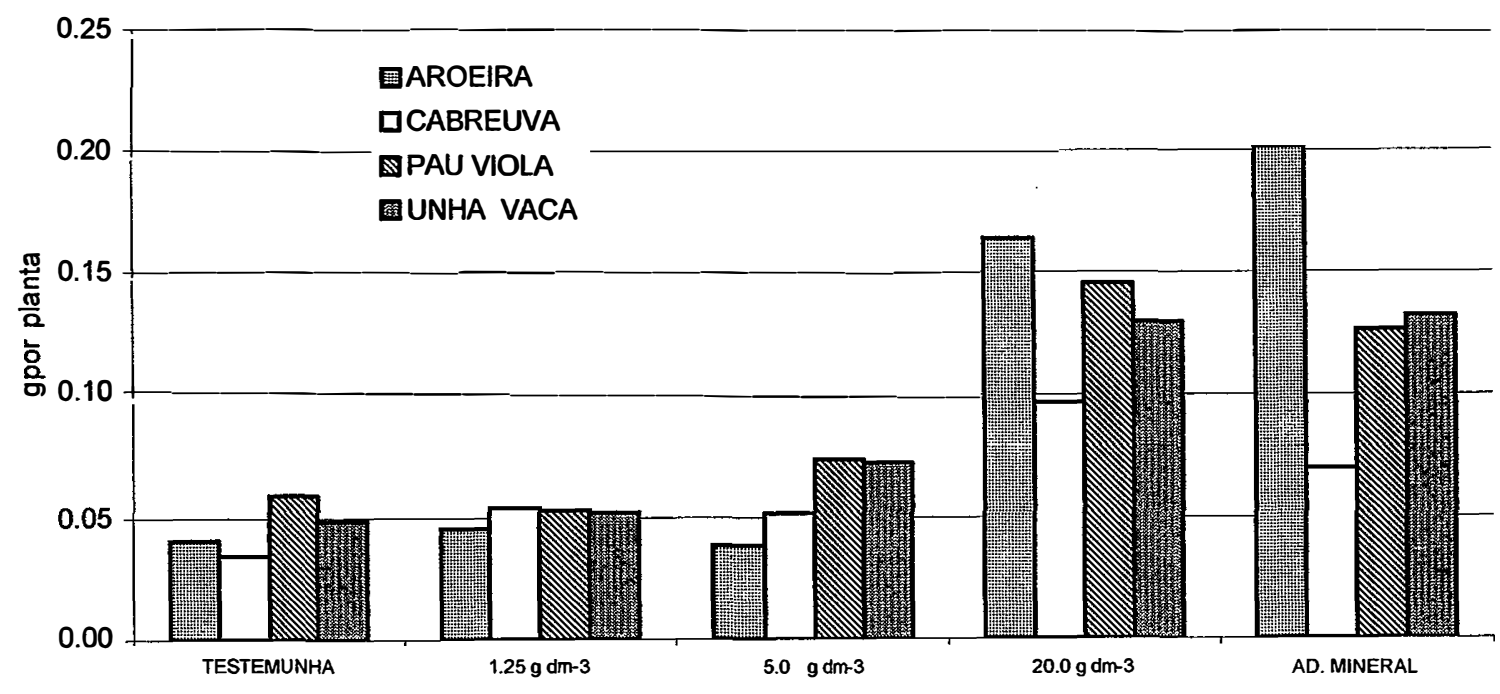

TRATAMENTOS

Figura 12 - Estoque de nitrogênio nos caules das quatro espécies (g planta $\left.{ }^{-1}\right)$, em função das doses de biossólido e adubação mineral

As doses crescentes de biossólido também promoveram maiores estoques de nitrogênio em raízes das quatro espécies. Nota-se, pela tabela 20 , diferenças significativas de estoque em resposta a dose de $20,0 \mathrm{~g} \mathrm{dm}^{-3} \mathrm{e}$ adubação mineral, quando comparadas à testemunha, porém sem diferenças significativas entre si. A dose de $5,0 \mathrm{~g} \mathrm{dm}^{-3}$ promoveu uma tendência de aumento de estoque nas raízes da cabreúva.

Tabela 20 . Estoque de nitrogênio (g planta $\left.{ }^{-1}\right)$ nas raízes das quatro espécies, em função das doses de biossólido e adubação mineral

\begin{tabular}{lrrrr}
\hline TRATA & AROEIRA & CABREUVA & PAU VIOLA & UNHA VACA \\
\hline TESTEMUNHA & $0.09 \mathrm{~b}$ & $0.07 \mathrm{~b}$ & $0.14 \mathrm{c}$ & $0.17 \mathrm{~b}$ \\
$1.25 \mathrm{~g} \mathrm{dm}^{-3}$ & $0.11 \mathrm{~b}$ & $0.08 \mathrm{~b}$ & $0.18 \mathrm{bc}$ & $0.18 \mathrm{~b}$ \\
$5.0 \mathrm{~g} \mathrm{dm}^{-3}$ & $0.12 \mathrm{ab}$ & $0.08 \mathrm{~b}$ & $0.26 \mathrm{~b}$ & $0.25 \mathrm{~b}$ \\
$20.0 \mathrm{~g} \mathrm{dm}^{-3}$ & $0.22 \mathrm{ab}$ & $0.12 \mathrm{a}$ & $0.43 \mathrm{a}$ & $0.34 \mathrm{a}$ \\
AD. MINERAL & $0.32 \mathrm{a}$ & $0.10 \mathrm{ab}$ & $0.43 \mathrm{a}$ & $0.33 \mathrm{a}$ \\
\hline
\end{tabular}

Médias acompanhadas da mesma letra não diferem entre si pelo teste Tukey a $5 \%$. 
O estoque total de nitrogênio na planta também aumentou nas quatro espécies com o aumento da dose de biossólido, tendendo a ser maior em resposta ao tratamento com $20,0 \mathrm{~g} \mathrm{dm}^{-3}$ e adubação mineral (Figura 13). As espécies de início de sucessão estocaram mais nitrogênio que as de final de sucessão, conforme observado por Gonçalves et al. (1992). Assim, a aroeira, o pau-de-viola e a unha-de-vaca estocaram mais nitrogênio que a cabreúva em resposta à dosagem mais alta de biossólido.

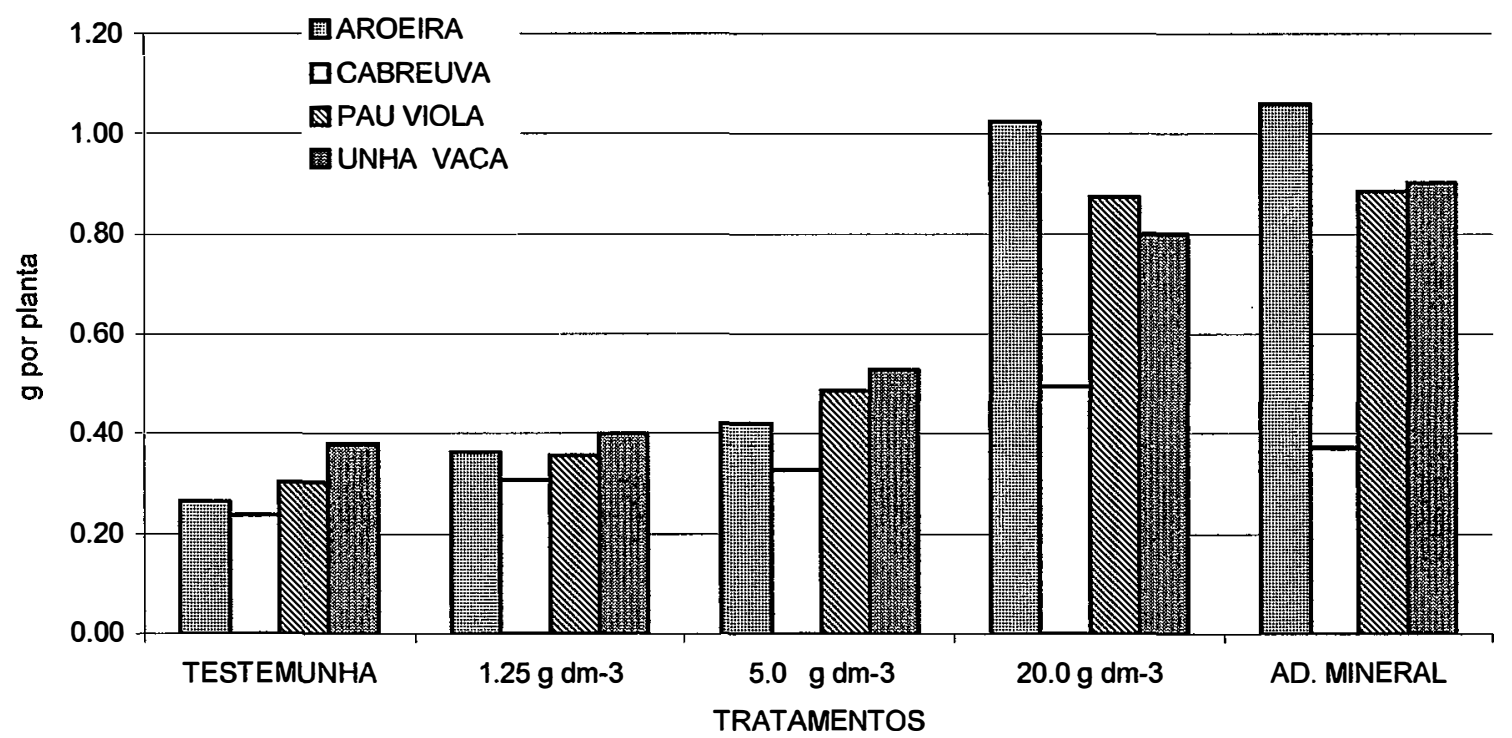

Figura 13 - Estoque total de nitrogênio na planta $\left(\mathrm{g}_{\text {planta }}{ }^{-1}\right)$, nas quatro espécies, em função das doses crescentes de biossólido e adubação mineral

Um fator importante para avaliação da eficácia do biossólido como fonte de nutrientes para as árvores é a quantidade do elemento fornecida pelo biossólido e a quantidade por elas utilizada. Uma forma indireta de se calcular a quantidade do elemento encontrada nos tecidos da planta devido ao efeito dos tratamentos com biossólido, segundo Labrecque (1995), pode ser feita através da subtração da quantidade do elemento encontrada nas plantas 
testemunhas, da quantidade encontrada nas plantas em cada tratamento e a relação porcentual deste resultado com o total do elemento fornecido pelo biossólido. A Tabela 21 mostra a porcentagem do nitrogênio utilizada pelas plantas das quatro espécies em resposta aos tratamentos. Percebe-se uma tendência de redução no uso aparente do nitrogênio com o aumento da dose de biossólido. Isso indica que o aumento do potencial do nitrogênio mineral pelo aumento da dose não reflete proporcionalmente em um maior uso do nutriente pelas espécies em estudo. A unha-de-vaca, por ser uma leguminosa, apresentou concentrações mais altas de nitrogênio em raizes e folhas na testemunha que as outras três espécies, apresentando um comportamento diferenciado.

Tabela 21. CUA - Coeficiente de Utilização Aparente de nitrogênio, em porcentagem, nas quatro espécies em função das doses crescentes de biossólido

\begin{tabular}{lcccc}
\hline TRATAMENTOS & AROEIRA & CABREUVA & PAU VIOLA & UNHA DE VACA \\
\hline $1.25 \mathrm{~g} \mathrm{dm}^{-3}$ & 49.76 & 35.95 & 27.07 & 9.90 \\
$5.0 \mathrm{~g} \mathrm{dm}^{-3}$ & 19.64 & 11.33 & 23.00 & 18.94 \\
$20.0 \mathrm{~g} \mathrm{dm}^{-3}$ & 23.98 & 8.09 & 17.95 & 13.30 \\
\hline
\end{tabular}

CUA $=100($ CET - CEC)/CEDB

$\mathrm{CET}=$ Conteúdo do Elemento nas árvores em cada Tratamento; $\mathrm{CEC}=$ Conteúdo do Elemento nas árvores do Controle (testemunha);

$\mathrm{CEDB}=$ Conteúdo do Elemento no Biossólido administrado em cada tratamento.

O cálculo da quantidade de biossólido a ser utilizado para fins agrícolas, segundo CETESB (1999) em vigência atual para o Estado de São Paulo, correlaciona a fração de mineralização do nitrogênio encontrada no biossólido com a quantidade de nitrogênio recomendada para a cultura específica (quantidade de $\mathrm{N}$ recomenda/quantidade disponível de $\mathrm{N}$ no biossólido). $\mathrm{Na}$ amostra do biossólido utilizado para esta pesquisa, a taxa de mineralização do nitrogênio aos 56 dias foi de $13 \%$, segundo resultados de análises realizadas pelo Laboratório de Química Ambiental/ESALQ/USP, constantes de relatório 
(Poggiani, 2003). Pode-se observar que durante os 100 dias de duração do ensaio desta pesquisa, a porcentagem do nitrogênio utilizada na forma mineral pelas quatro espécies foi superior ao valor mencionado no supracitado relatório referente à determinação da taxa de degradação da fração orgânica do biossólido seco termicamente em condições padronizadas de laboratório. Isto sugere que o processo de mineralização pode se dar de forma mais rápida em campo. Segundo Mattiazzo et al. (2000), na literatura internacional a presença de nitrogênio em biossólido e a sua mineralização têm sido objeto de estudos de diversos autores na literatura internacional, mas são escassos os trabalhos publicados sobre o tema em condições de solo sob clima tropical. Barreto (1995), incorporando doses de 18,9 e $37,7 \mathrm{Mg} \mathrm{ha}^{-1}$ em solo arenoso, encontrou para o $\mathrm{N}$ inorgânico valores de 34,7 e $23,7 \%$ do total adicionado ao solo respectivamente, o que indica que a taxa de mineralização do nitrogênio reduz com o aumento da dose de biossólido aplicada. Mattiazzo et al., citados por Mattiazzo et al. (2000), estudando a velocidade da degradação da fração orgânica do biossólido, verificaram que ela diminuiu com o aumento da quantidade de biossólido adicionada ao solo. Estes dados indicam que para o nitrogênio o CUA diminui com o aumento das doses de biossólido aplicadas e também pela redução da taxa de mineralização do nitrogênio orgânico e conseqüentemente da redução do nitrogênio mineral disponível às plantas.

Outro parâmetro utilizado foi o EUN - Eficiência na Utilização de Nutrientes, que relaciona a produção de matéria seca com o estoque do nutriente. Observam-se pela Tabela 22 valores mais elevados de produção de matéria seca por grama de nitrogênio na testemunha, excetuando-se a unhade-vaca, e uma redução na produção de matéria seca por unidade de nitrogênio estocado com o aumento das doses de biossólido e adubação mineral. Isto indica que quando se aumentaram as doses de biossólido, as espécies florestais estudadas acumularam mais nitrogênio para produzirem a mesma quantidade de matéria seca. Guedes (2005), afirma que este parâmetro deve ser utilizado cuidadosamente, pois não tem relação direta com a produtividade 
de fitomassa. Afirma que existem plantas com elevada produtividade em matéria seca e elevado conteúdo de nutriente com o mesmo EUN que plantas com baixa produtividade de matéria seca e pequeno conteúdo de nutrientes.

Tabela 22. EUN - Eficiência na Utilização do Nitrogênio ( $\mathrm{g}$ de matéria seca $\mathrm{g}$ de $\mathrm{N}^{-1}$ ) pelas plantas das quatro espécies, em função das doses crescentes de biossólido e da adubação mineral

\begin{tabular}{lcccc}
\hline TRATAMENTOS & AROEIRA & CABREUVA & PAU VIOLA & UNHA DE VACA \\
\hline TESTEMUNHA & 170.08 & 93.22 & 124.95 & 78.68 \\
$1.25 \mathrm{~g} \mathrm{dm}^{-3}$ & 146.92 & 71.44 & 105.82 & 84.25 \\
$5.0 \mathrm{~g} \mathrm{dm}^{-3}$ & 162.48 & 70.81 & 111.86 & 81.33 \\
$20.0 \mathrm{~g} \mathrm{dm}^{-3}$ & 127.19 & 58.30 & 104.01 & 69.88 \\
AD. MINERAL & 152.71 & 63.43 & 116.08 & 74.10 \\
\hline
\end{tabular}

Constata-se que a cabreúva, espécie de final de sucessão, exibe o menor EUN para os tratamentos com biossólido entre as quatro espécies e a aroeira o maior índice por ser espécie pioneira. O pau-de-viola, espécie secundária inicial, exibe um valor intermediário. A unha-de-vaca exibe comportamento diferenciado e, mesmo sendo pioneira, não teve uso tão eficiente do nitrogênio quanto a aroeira, o que pode ser explicado por ser leguminosa, conseguindo por simbiose com micorrizas nativas maiores estoques de nitrogênio, como pode ser confirmado pela Tabela 19, onde se observam valores mais elevados de nitrogênio para a unha-de-vaca na testemunha do que nas outras espécies.

De maneira geral, pode-se concluir que o biossólido é uma boa fonte de nitrogênio para mudas de árvores, destacando-se a dose de $20,0 \mathrm{~g} \mathrm{dm}^{-3}$, que se igualou a adubação mineral. 


\subsubsection{Fósforo}

As concentrações de fósforo foram significativas para todas as espécies, excetuando-se para as raízes da cabreúva, conforme Tabela 23 .

A dose de $20,0 \mathrm{~g} \mathrm{dm}^{-3}$ de biossólido aumentou significativamente os teores de fósforo nas folhas das quatro espécies, igualando-se aos resultados da adubação mineral para pau-de-viola e unha-de-vaca. A dose de $5,0 \mathrm{~g} \mathrm{dm}^{-3}$ de biossólido aumentou significativamente os teores de fósforo em folhas de cabreúva e unha-de-vaca e promoveu uma tendência de aumento em folhas de aroeira e pau-de-viola. A dose de $1,25 \mathrm{~g} \mathrm{dm}^{-3}$ promoveu aumento significativo no teor de fósforo nas folhas da cabreúva e uma tendência de aumento em folhas de pau-de-viola. Os maiores aumentos da concentração de fósforo em folhas promovidos pela maior dosagem de biossólido $\left(20,0 \mathrm{~g} \mathrm{dm}^{-3}\right)$ com relação à testemunha foram para o pau-de-viola, correspondendo a $79 \%$ e para unhade-vaca, correspondendo a $98 \%$.

A dose de $20 \mathrm{~g} \mathrm{dm}^{-3}$ promoveu aumento significativo na concentração de fósforo em raízes de aroeira, pau-de-viola e unha-de-vaca, mas não promoveu aumentos significativos em raízes de cabreúva. O pau-de-viola e a unha-devaca, que receberam $5,0 \mathrm{~g} \mathrm{dm}^{-3}$ de biossólido, concentraram mais fósforo em raízes que a testemunha. O pau-de-viola foi a única espécie que aumentou a concentração de fósforo em raízes recebendo $1,25 \mathrm{~g} \mathrm{dm}^{-3}$ de biossólido. A dose de $20 \mathrm{~g} \mathrm{dm}^{-3}$ de biossólido promoveu resultados estatisticamente iguais aos da adubação mineral nas raízes. Os aumentos porcentuais mais expressivos com relação à testemunha foram de $90 \%$ para a aroeira, $78 \%$ para o pau-de-viola e $145 \%$ para raízes de unha-de-vaca. 
Tabela 23. Concentrações médias de fósforo $\left(\mathrm{g} \mathrm{kg}^{-1}\right)$ em folhas e raízes das quatro espécies, em função das doses crescentes de biossólido e adubação mineral

\begin{tabular}{lrrrrrrrr}
\hline TRATAMENTO & \multicolumn{2}{c}{ AROEIRA } & \multicolumn{2}{c}{ CABREÚVA } & \multicolumn{2}{c}{ PAU-DE-VIOLA } & \multicolumn{2}{c}{ UNHA-DE-VACA } \\
& FOLHA & RAIZ & FOLHA & RAIZ & FOLHA & RAIZ & FOLHA & RAIZ \\
\hline TESTEMUNHA & $0.71 \mathrm{c}$ & $0.82 \mathrm{~b}$ & $1.19 \mathrm{c}$ & $0.98 \mathrm{a}$ & $0.87 \mathrm{~b}$ & $1.29 \mathrm{c}$ & $0.90 \mathrm{~b}$ & $1.09 \mathrm{c}$ \\
$1.25 \mathrm{~g} \mathrm{dm}^{-3}$ & $0.90 \mathrm{bc}$ & $0.80 \mathrm{~b}$ & $1.73 \mathrm{~b}$ & $0.88 \mathrm{a}$ & $0.11 \mathrm{ab}$ & $2.11 \mathrm{~b}$ & $1.20 \mathrm{~b}$ & $1.62 \mathrm{bc}$ \\
$5.0 \mathrm{~g} \mathrm{dm}^{-3}$ & $1.02 \mathrm{bc}$ & $1.10 \mathrm{ab}$ & $2.25 \mathrm{~b}$ & $1.36 \mathrm{a}$ & $1.15 \mathrm{ab}$ & $2.22 \mathrm{~b}$ & $1.64 \mathrm{a}$ & $1.83 \mathrm{~b}$ \\
$20.0 \mathrm{~g} \mathrm{dm}^{-3}$ & $1.03 \mathrm{~b}$ & $1.56 \mathrm{a}$ & $1.85 \mathrm{~b}$ & $1.24 \mathrm{a}$ & $1.55 \mathrm{a}$ & $2.30 \mathrm{a}$ & $1.79 \mathrm{a}$ & $2.67 \mathrm{a}$ \\
AD. MINERAL & $1.38 \mathrm{a}$ & $1.46 \mathrm{a}$ & $3.27 \mathrm{a}$ & $1.72 \mathrm{a}$ & $1.36 \mathrm{a}$ & $2.46 \mathrm{a}$ & $1.67 \mathrm{a}$ & $2.74 \mathrm{a}$ \\
\hline
\end{tabular}

Médias acompanhadas da mesma letra não diferem entre si pelo teste Tukey a $5 \%$.

As concentrações de fósforo total em tecidos vegetais encontram-se entre 0,1 e $1,5 \%$ da matéria seca, sendo mais comum entre 0,1 e $0,5 \%$, segundo Sarruge \& Haag, (1974). Percebe-se que para o componente folhas as concentrações de fósforo nas plantas testemunhas estão abaixo dos valores médios, indicando deficiência de fósforo, excetuando-se a cabreúva. As doses de $5,0 \mathrm{~g} \mathrm{dm}^{-3}, 20,0 \mathrm{~g} \mathrm{dm}^{-3}$ e adubação mineral elevaram as concentrações médias de fósforo em folhas e raízes das quatro espécies para o intervalo adequado indicado pelos mesmos autores.

Gonçalves et al. (1992), estudando nutrição mineral em espécies florestais nativas em condições de viveiro, encontraram concentrações médias de fósforo na parte aérea de $4 \mathrm{~g} \mathrm{~kg}^{-1}$ de matéria seca, portanto acima dos valores observados na Tabela 22 . Isto pode ser explicado pelo efeito de diluição do nutriente na biomassa produzida, pois a média de matéria seca encontrada na parte aérea das plantas pelos autores foi de $4,5 \mathrm{~g}$ para as espécies pioneiras, 2,9 $\mathrm{g}$ para as secundárias e clímax. Nas quatro espécies em estudo nesta tese, a média mínima de matéria seca foi de $14,9 \mathrm{~g}$ para testemunha em cabreúva (secundária tardia) e média máxima de 103,33 g para aroeira (pioneira), quando administradas $20,0 \mathrm{~g} \mathrm{dm}^{-3}$ de biossólido. Portanto, o estudo dos estoques de fósforo encontrados na matéria seca das quatro 
espécies proporcionará análises mais precisas, do que simplesmente a análise de concentrações.

Comparando-se as concentrações de fósforo nas folhas entre as quatro espécies, observa-se, pela Tabela 24 , que a cabreúva concentrou as maiores quantidades para todos os tratamentos. Em resposta à maior dose de biossólido, a aroeira foi a espécie que menos concentrou.

Tabela 24 . Concentrações médias de fósforo $\left(\mathrm{g} \mathrm{kg}^{-1}\right)$ nas folhas comparando as quatro espécies, em função das doses crescentes de biossólido e adubação mineral

\begin{tabular}{|c|c|c|c|c|}
\hline ESPÉCIES & $1.25 \mathrm{~g} \mathrm{dm}^{-3}$ & $5.0 \mathrm{~g} \mathrm{dm}^{-3}$ & $20.0 \mathrm{~g} \mathrm{dm}^{-3}$ & AD. MINERAL \\
\hline AROEIRA & $0.90 \mathrm{~b}$ & $1.01 b$ & $1.03 b$ & $1.38 b$ \\
\hline CABREUVA & $1.73 a$ & $2.27 a$ & $1.85 a$ & $3.24 a$ \\
\hline PAU-DE-VIOLA & $1.10 \mathrm{~b}$ & $1.15 b$ & $1.55 a$ & $1.37 \mathrm{~b}$ \\
\hline UNHA-DE-VACA & $1.20 b$ & $1.64 b$ & $1.79 a$ & $1.69 \mathrm{~b}$ \\
\hline
\end{tabular}

Médias acompanhadas da mesma letra não diferem entre si pelo teste Tukey a $5 \%$.

Comparando-se a concentração de fósforo nas raízes entre as quatro espécies, observa-se pela Tabela 25 , que o pau-de-viola foi a que mais concentrou fósforo em resposta a todos os tratamentos, seguida pela unha-devaca. A aroeira e a cabreúva apresentaram concentrações estatisticamente iguais.

Tabela 25 . Concentrações médias de fósforo $\left(\mathrm{g} \mathrm{kg}^{-1}\right)$ nas raízes, comparando as quatro espécies, em função das doses crescentes de biossólido e adubação mineral

\begin{tabular}{|c|c|c|c|c|}
\hline ESPÉCIES & $1.25 \mathrm{~g} \mathrm{dm}^{-3}$ & $5.0 \mathrm{~g} \mathrm{dm}^{-3}$ & $20.0 \mathrm{~g} \mathrm{dm}^{-3}$ & AD. MINERAL \\
\hline AROEIRA & $0.90 c$ & $1.10 b$ & $1.56 b$ & $1.46 b$ \\
\hline CABREUVA & $0.88 c$ & $1.36 \mathrm{~b}$ & $1.24 b$ & $1.76 b$ \\
\hline PAU-DE-VIOLA & $2.11 a$ & $2.22 a$ & $2.30 a$ & $2.46 a b$ \\
\hline UNHA-DE-VACA & $1.62 b$ & $1.83 a b$ & $2.67 a$ & $2.74 a$ \\
\hline
\end{tabular}


O estoque de fósforo nas folhas das quatro espécies pode ser visto pela Tabela 26 . Observa-se que a dose de $20,0 \mathrm{~g} \mathrm{dm}^{-3}$ de biossólido e a adubação mineral aumentaram significativamente o estoque de fósforo em folhas de todas as espécies com relação à testemunha e com resultados iguais entre si, exceto para a aroeira, que foi menor. A dose de $5 \mathrm{~g} \mathrm{dm}^{-3}$ aumentou significativamente o estoque nas folhas da aroeira e da unha-de-vaca e promoveu uma tendência de aumento na cabreúva. A dose de $1,25 \mathrm{~g} \mathrm{dm}^{-3}$ promoveu uma tendência de aumento de estoque em folhas da unha-de-vaca.

Tabela 26 . Estoque de fósforo nas folhas das quatro espécies (g planta ${ }^{-1}$ ), em função das doses crescentes de biossólido e adubação mineral

\begin{tabular}{lrrrr}
\hline TRATAMENTOS & AROEIRA & CABREUVA & PAU-DE-VIOLA & UNHA-DE-VACA \\
\hline TESTEMUNHA & $0.09 \mathrm{c}$ & $0.09 \mathrm{~b}$ & $0.08 \mathrm{~b}$ & $0.08 \mathrm{c}$ \\
$1.25 \mathrm{~g} \mathrm{dm}^{-3}$ & $0.13 \mathrm{bc}$ & $0.14 \mathrm{~b}$ & $0.10 \mathrm{~b}$ & $0.11 \mathrm{bc}$ \\
$5.0 \mathrm{~g} \mathrm{dm}^{-3}$ & $0.19 \mathrm{~b}$ & $020 \mathrm{ab}$ & $0.14 \mathrm{~b}$ & $0.17 \mathrm{~b}$ \\
$20.0 \mathrm{~g} \mathrm{dm}^{-3}$ & $0.41 \mathrm{~b}$ & $0.21 \mathrm{ab}$ & $0.35 \mathrm{a}$ & $0.27 \mathrm{a}$ \\
AD. MINERAL & $0.58 \mathrm{a}$ & $0.27 \mathrm{a}$ & $0.33 \mathrm{a}$ & $0.27 \mathrm{a}$ \\
\hline
\end{tabular}

Médias acompanhadas da mesma letra não diferem entre si pelo teste Tukey a $5 \%$.

O estoque de fósforo no caule foi menor para a cabreúva e unha-de-vaca em todos os tratamentos, como mostra a Figura 14 . A aroeira e o pau-de- viola estocaram mais fósforo no caule para os tratamentos com $20,0 \mathrm{~g} \mathrm{dm}^{-3} \mathrm{de}$ biossólido e a adubação mineral. Observa-se que o acúmulo de fósforo no caule foi próximo ao acúmulo nas folhas de aroeira e pau-de-viola, indicando serem pequenas as diferenças de acúmulo entre caule e folhas nos estágios iniciais de crescimento das mudas de espécies arbóreas consideradas de início de sucessão. 


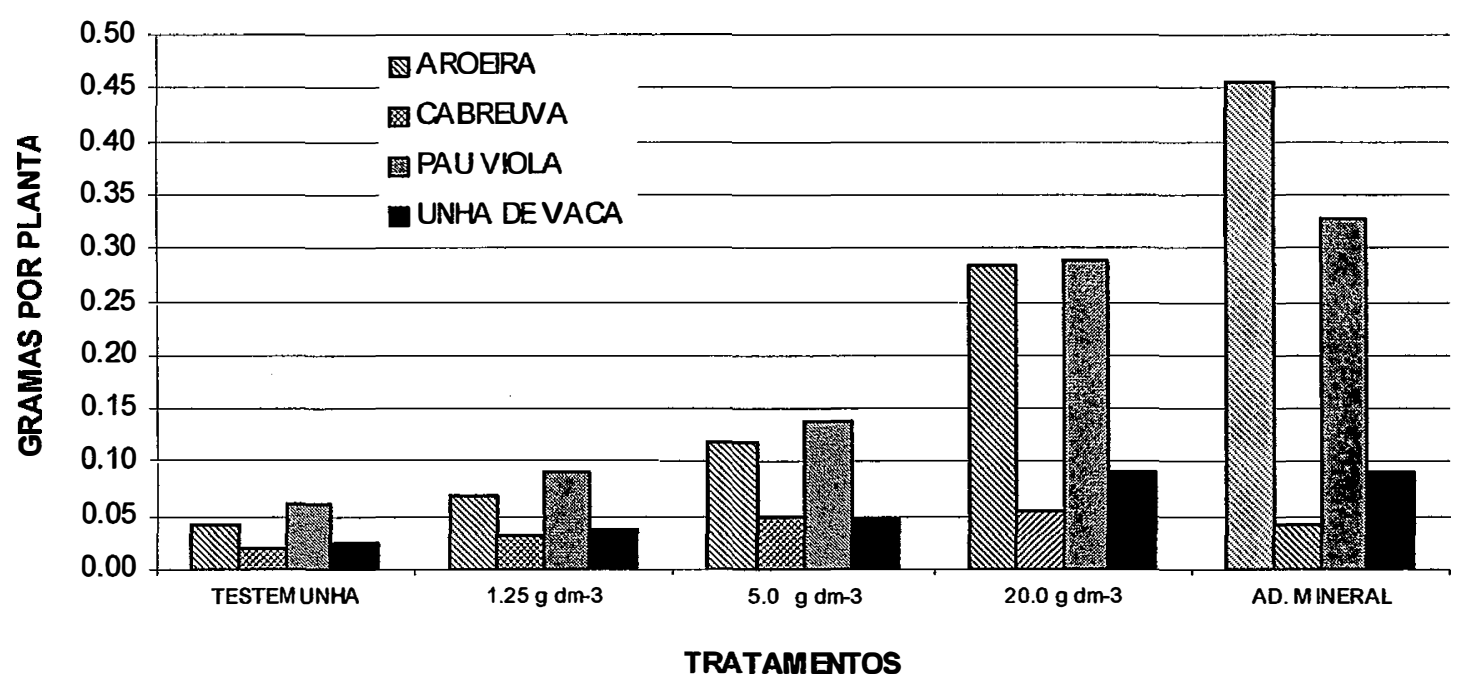

Figura 14 - Estoque de fósforo nos caules das quatro espécies (g planta $\left.{ }^{-1}\right)$, em função das doses crescentes de biossólido e adubação mineral

O aumento do estoque de fósforo em raízes, exibido pela tabela 27 , não foi estatisticamente significativo para cabreúva em relação a nenhum dos tratamentos, mas foi significativo para aroeira, pau-de-viola e unha-de-vaca em resposta aos tratamentos com $20,0 \mathrm{~g} \mathrm{dm}^{-3}$ de biossólido e a adubação mineral, que não diferenciaram entre si. Respostas também significativas obtiveram o pau-de-viola e a unha-de-vaca ao tratamento com $5,0 \mathrm{~g} \mathrm{dm}^{-3}$.

Tabela 27 . Estoque de fósforo nas raízes das quatro espécies (g planta ${ }^{-1}$ ),em função das doses crescentes de biossólido e adubação mineral

\begin{tabular}{lrrrr}
\hline TRATAMENTOS & AROEIRA & CABREUVA & PAU-DE-VIOLA & UNHA-DE-VACA \\
\hline TESTEMUNHA & $0.11 \mathrm{~b}$ & $0.06 \mathrm{a}$ & $0.20 \mathrm{c}$ & $0.13 \mathrm{c}$ \\
$1.25 \mathrm{~g} \mathrm{dm}^{-3}$ & $0.14 \mathrm{~b}$ & $0.06 \mathrm{a}$ & $0.33 \mathrm{bc}$ & $0.22 \mathrm{bc}$ \\
$5.0 \mathrm{~g} \mathrm{dm}^{-3}$ & $0.49 \mathrm{~b}$ & $0.09 \mathrm{a}$ & $0.5 \mathrm{~b}$ & $0.33 \mathrm{~b}$ \\
$20.0 \mathrm{~g} \mathrm{dm}^{-3}$ & $0.41 \mathrm{a}$ & $0.09 \mathrm{a}$ & $1.10 \mathrm{a}$ & $0.49 \mathrm{a}$ \\
AD. MINERAL & $0.47 \mathrm{a}$ & $0.12 \mathrm{a}$ & $0.94 \mathrm{a}$ & $0.58 \mathrm{a}$
\end{tabular}

Médias acompanhadas da mesma letra não diferem entre si pelo teste Tukey a $5 \%$. 
O estoque de fósforo nas raízes de aroeira foi igual ao das folhas. Foi maior em folhas da cabreúva e maior em raízes de pau-de-viola e unha-de-vaca do que em suas folhas. Destaca-se dentre as espécies, a quantidade estocada em raízes de pau-de-viola em resposta a todos os tratamentos, sendo mais que o dobro do observado para unha-de-vaca e aroeira e doze vezes maior do que o acumulado pela cabreúva em resposta a $20,0 \mathrm{~g} \mathrm{dm}^{-3}$ de biossólido.

O estoque total de fósforo, expresso pela Figura 15 , mostra valores inferiores a $0,10 \mathrm{~g}$ por planta de cabreúva em todos os tratamentos. Este resultado pode ser atribuído ao fato desta espécie ser característica de final de sucessão e ter apresentado crescimento inferior às demais e, conseqüentemente, ter assimilado uma menor quantidade de fósforo. $A$ unhade-vaca teve um comportamento intermediário, sendo que os maiores estoques foram assimilados pela aroeira e pelo pau-de-viola.

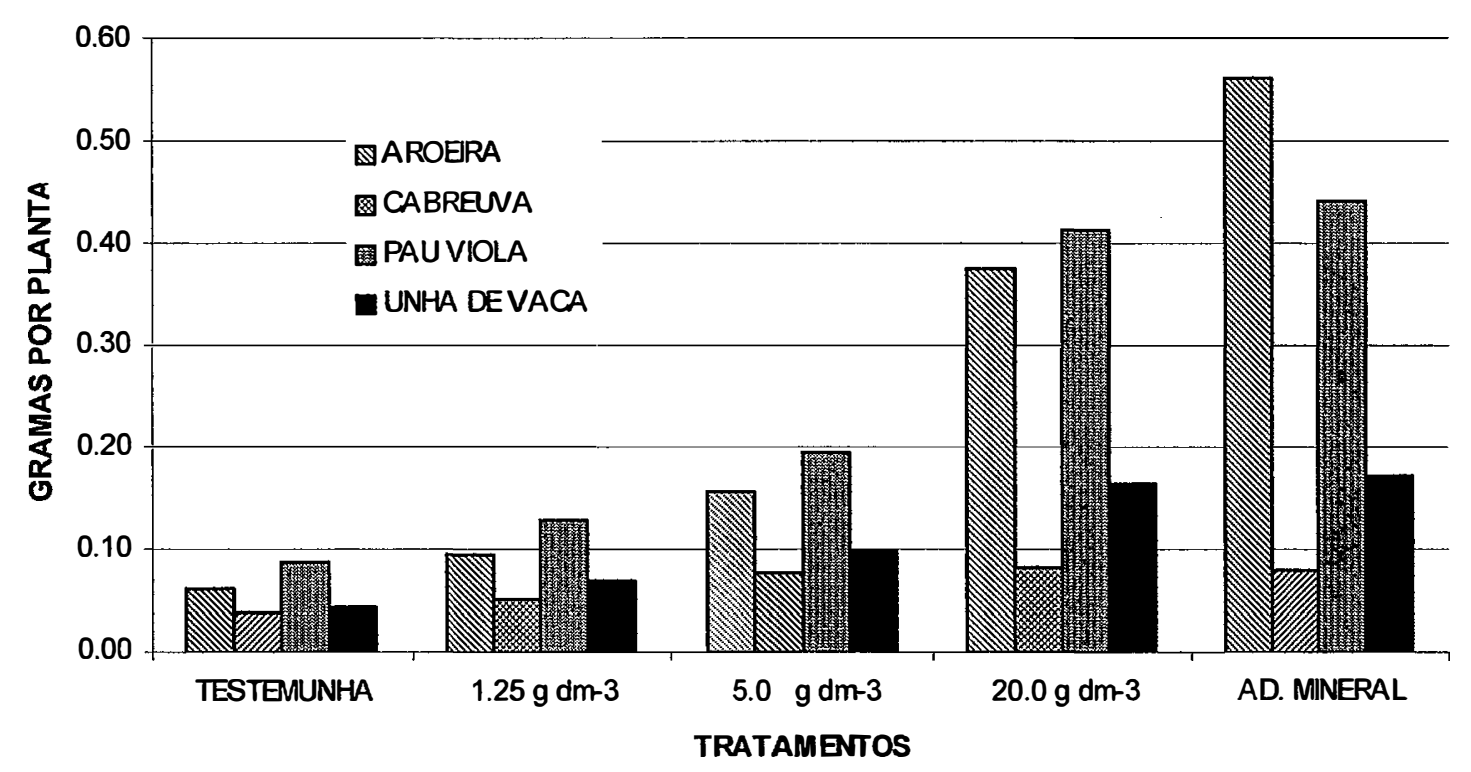

Figura 15 - Estoque total de fósforo nas quatro espécies (g planta ${ }^{-1}$ ), em função das doses crescentes de biossólido e adubação mineral

A utilização aparente do fósforo pelas quatro espécies pode ser vista pela Tabela 28 , onde se vê uma redução no CUA com o aumento da dose de 
biossólido, a exemplo do que aconteceu com o nitrogênio, mantendo uma proporção inversa. Mattiazzo et al., citados por Mattiazzo et al. (2000), verificaram que a velocidade da degradação da fração orgânica do biossólido, diminuiu com o aumento da quantidade de biossólido adicionada ao solo e conseqüentemente, pode ter reduzido a disponibilidade dos nutrientes, inclusive o fósforo.

Tabela 28. CUA - Coeficiente de Utilização Aparente de fósforo em porcentagem pelas plantas das quatro espécies, em função das doses crescentes de biossólido e da adubação mineral

\begin{tabular}{lcccc}
\hline TRATAMENTO & AROEIRA & CABREUVA & PAU-DE-VIOLA & UNHA VACA \\
\hline $1.25 \mathrm{~g} \mathrm{dm}^{-3}$ & 40.05 & 17.70 & 49.70 & 27.91 \\
$5.0 \mathrm{~g} \mathrm{dm}^{-3}$ & 28.09 & 12.02 & 31.74 & 15.65 \\
$20.0 \mathrm{~g} \mathrm{dm}^{-3}$ & 23.03 & 3.38 & 23.91 & 8.82 \\
\hline
\end{tabular}

Percebe-se que a utilização pelas espécies de início de sucessão, como a aroeira, pau-de-viola e unha-de-vaca é maior que a cabreúva, característica espécie de final de sucessão, também observado por Gonçalves et al (1992). A espécie que mais utilizou fósforo foi o pau-de-viola, apresentando estoques elevados principalmente nas raizes.

$\mathrm{O}$ biossólido demonstrou ser também boa fonte de fósforo às mudas de árvores, principalmente na dose de $20 \mathrm{~g} \mathrm{dm}^{-3}$, igualando-se à quantidade de fósforo fornecida pela adubação mineral, podendo vir a substituí-la no cultivo de mudas de árvores. 


\subsubsection{Potássio}

Por ser um sal muito solúvel, o potássio dissolve-se na água, sendo encontrado em baixas concentrações no biossólido, visto que se precipita no tratamento do esgoto, devendo ser adicionado em formas solúveis como complemento aplicação de biossólido. Observa-se, pela Tabela 29, uma tendência à redução na concentração de potássio em folhas das quatro espécies, com o aumento da dose de biossólido, o que pode ser atribuído ao efeito da diluição do nutriente na matéria seca de cada espécie, que aumentou com as doses crescentes de biossólido.

Tabela 29 . Concentração de potássio nas folhas $\left(\mathrm{g} \mathrm{kg}^{-1}\right)$ das quatro espécies, em função das doses crescentes de biossólido e adubação mineral

\begin{tabular}{lrrrr}
\hline TRATAMENTOS & AROEIRA & CABREUVA & PAU VIOLA & UNHA VACA \\
\hline TESTEMUNHA & $8.60 \mathrm{a}$ & $11.30 \mathrm{a}$ & $11.00 \mathrm{a}$ & $6.75 \mathrm{a}$ \\
$1.25 \mathrm{~g} \mathrm{dm}-3$ & $10.25 \mathrm{a}$ & $12,00 \mathrm{a}$ & $11.35 \mathrm{a}$ & $7.15 \mathrm{a}$ \\
$5.0 \mathrm{~g} \mathrm{dm}-3$ & $9.20 \mathrm{a}$ & $12.35 \mathrm{a}$ & $11.2 \mathrm{a}$ & $8.00 \mathrm{a}$ \\
$20.0 \mathrm{~g} \mathrm{dm}-3$ & $5.85 \mathrm{~b}$ & $11.15 \mathrm{a}$ & $8.65 \mathrm{a}$ & $7.55 \mathrm{a}$ \\
AD. MINERAL & $3.40 \mathrm{~b}$ & $11.55 \mathrm{a}$ & $4.2 \mathrm{~b}$ & $8.25 \mathrm{a}$ \\
\hline
\end{tabular}

Médias acompanhadas da mesma letra não diferem entre si pelo teste Tukey a $5 \%$.

As concentrações do potássio em tecidos de plantas variam entre 2 e $110 \mathrm{~g} \mathrm{~kg}^{-1}$, segundo Sarruge \& Haag (1974). Percebem-se pela tabela 29 , que os valores encontrados estão dentro do intervalo, não indicando deficiência deste nutriente nas quatro espécies. Pesquisando nutrição de espécies nativas em viveiro, Gonçalves et al. (1992) encontraram valores médios de concentração de potássio próximos aos observados neste resultado. A apresentação dos estoques permitirá uma análise mais consistente deste resultado. 
Dentre as espécies estudadas, existem diferenças nas concentrações de potássio nas folhas, como pode ser visto pela Tabela 30 . Em resposta aos tratamentos de $20,0 \mathrm{~g} \mathrm{dm}^{3}$ e adubação mineral, as espécies de início de sucessão, que produziram maiores quantidades de matéria seca, apresentaram menores concentrações que a cabreúva, de final de sucessão, com menor produção de matéria seca.

Tabela 30 . Concentração de potássio nas folhas $\left(\mathrm{g} \mathrm{kg}^{-1}\right)$ comparando as quatro espécies, em função das doses crescentes de biossólido e adubação mineral

\begin{tabular}{|c|c|c|c|c|}
\hline ESPÉCIES & $1.25 \mathrm{~g} \mathrm{dm}^{-3}$ & $5.0 \mathrm{~g} \mathrm{dm}^{-3}$ & $20.0 \mathrm{~g} \mathrm{dm}^{-3}$ & AD. MINERAL \\
\hline AROEIRA & $10.25 a$ & $9.2 b$ & $5.85 b$ & $3.40 \mathrm{~b}$ \\
\hline CABREUVA & $12.00 \mathrm{a}$ & $12.35 a$ & $11.15 a$ & $11.55 a$ \\
\hline PAU-DE-VIOLA & $11.35 a$ & 11.20ab & $8.65 a b$ & $4.2 b$ \\
\hline UNHA-DE-VACA & $7.15 b$ & $8.00 \mathrm{~b}$ & $7.55 b$ & $8.25 a$ \\
\hline
\end{tabular}

Médias acompanhadas da mesma letra não diferem entre si pelo teste Tukey a $5 \%$.

As concentrações de potássio em raízes das quatro espécies podem ser observadas pela Tabela 31 . Percebe-se na aroeira uma redução e no pau-deviola uma tendência de redução na concentração de potássio nas raízes com o aumento das doses de biossólido, não havendo diferenças significativas para a cabreúva e unha-de-vaca.

Tabela 31 . Concentração de potássio nas raízes $\left(\mathrm{g} \mathrm{kg}^{-1}\right)$ das quatro espécies , em função das doses crescentes de biossólido e adubação mineral

\begin{tabular}{lrrrr}
\hline TRATAMENTOS & AROEIRA & CABREUVA & PAU VIOLA & UNHA VACA \\
\hline TESTEMUNHA & $9.30 \mathrm{a}$ & $6.00 \mathrm{a}$ & $9.85 \mathrm{ab}$ & $9.50 \mathrm{a}$ \\
$1.25 \mathrm{~g} \mathrm{dm}-3$ & $10.20 \mathrm{a}$ & $6.50 \mathrm{a}$ & $11.25 \mathrm{a}$ & $10.55 \mathrm{a}$ \\
$5.0 \mathrm{~g} \mathrm{dm}-3$ & $8.80 \mathrm{a}$ & $6.70 \mathrm{a}$ & $7.55 \mathrm{~b}$ & $10.85 \mathrm{a}$ \\
$20.0 \mathrm{~g} \mathrm{dm}-3$ & $4.20 \mathrm{~b}$ & $6.65 \mathrm{a}$ & $7.10 \mathrm{~b}$ & $9.85 \mathrm{a}$ \\
AD. MINERAL & $3.75 \mathrm{~b}$ & $7.70 \mathrm{a}$ & $7.10 \mathrm{~b}$ & $10.10 \mathrm{a}$ \\
\hline Médias acompanhadas da mesma letra não diferem entre si pelo teste Tukey a 5\%.
\end{tabular}


Entre as espécies, observado pela Tabela 32, a unha-de-vaca concentrou mais potássio, seguida pelo pau-de-viola e cabreúva, sendo que a aroeira apresentou valores mais baixos de potássio em suas raízes.

Tabela 32 . Concentração de potássio nas raízes $\left(\mathrm{g} \mathrm{kg}^{-1}\right)$, comparando as quatro espécies, em função das doses crescentes de biossólido e adubação mineral

\begin{tabular}{|c|c|c|c|c|}
\hline ESPÉCIES & $1.25 \mathrm{~g} \mathrm{dm}^{-3}$ & $5.0 \mathrm{~g} \mathrm{dm}^{-3}$ & $20.0 \mathrm{~g} \mathrm{dm}^{-3}$ & AD. MINERAL \\
\hline AROEIRA & $10.20 a$ & $8.80 a$ & $4.20 \mathrm{c}$ & $3.75 c$ \\
\hline CABREUVA & $6.50 \mathrm{~b}$ & $6.70 \mathrm{~b}$ & $6.65 b$ & 7.70ab \\
\hline PAU-DE-VIOLA & $11.25 a$ & $7.55 a$ & $7.10 \mathrm{~b}$ & $7.10 b$ \\
\hline UNHA-DE-VACA & $10.55 a$ & $10.85 a$ & $9.85 a$ & $10.10 a$ \\
\hline
\end{tabular}

O estoque de potássio nas folhas, exibido pela Tabela 33, foi aumentado em resposta aos tratamentos de $20,0 \mathrm{~g} \mathrm{dm}^{3}$ e adubação mineral na aroeira e no pau viola, exibindo uma tendência de aumento na unha-de-vaca. Para a cabreúva, não houve diferenças significativas por ser de final de sucessão.

Tabela 33 .Estoque de potássio nas folhas das quatro espécies (g planta ${ }^{-1}$ ), em função das doses de biossólido e adubação mineral

\begin{tabular}{lrrrr}
\hline TRATAMENTOS & AROEIRA & CABREUVA & PAU VIOLA & UNHA VACA \\
\hline TESTEMUNHA & $0.11 \mathrm{~b}$ & $0.09 \mathrm{a}$ & $0.11 \mathrm{~b}$ & $0.06 \mathrm{~b}$ \\
$1.25 \mathrm{~g} \mathrm{dm}-3$ & $0.15 \mathrm{~b}$ & $0.10 \mathrm{a}$ & $0.11 \mathrm{~b}$ & $0.07 \mathrm{~b}$ \\
$5.0 \mathrm{~g} \mathrm{dm}-3$ & $0.17 \mathrm{~b}$ & $0.11 \mathrm{a}$ & $0.14 \mathrm{~b}$ & $0.09 \mathrm{~b}$ \\
$20.0 \mathrm{~g} \mathrm{dm}-3$ & $0.24 \mathrm{a}$ & $0.13 \mathrm{a}$ & $0.19 \mathrm{a}$ & $0.11 \mathrm{ab}$ \\
AD. MINERAL & $0.14 \mathrm{~b}$ & $0.09 \mathrm{a}$ & $0.10 \mathrm{~b}$ & $0.13 \mathrm{a}$ \\
\hline
\end{tabular}

Médias acompanhadas da mesma letra não diferem entre si pelo teste Tukey a $5 \%$.

O estoque de potássio no caule, da mesma forma que os demais nutrientes, é mais baixo do que nos demais compartimentos das plantas. Nota- 
se pela Figura 16, uma tendência ao aumento do estoque de potássio com o aumento das doses de biossólido, seguindo proporção semelhante à do estoque nas folhas. Destaca-se o estoque maior na aroeira, por ser espécie pioneira. Embora tenha concentrado menos, produziu mais matéria seca na parte aérea que as outras espécies.

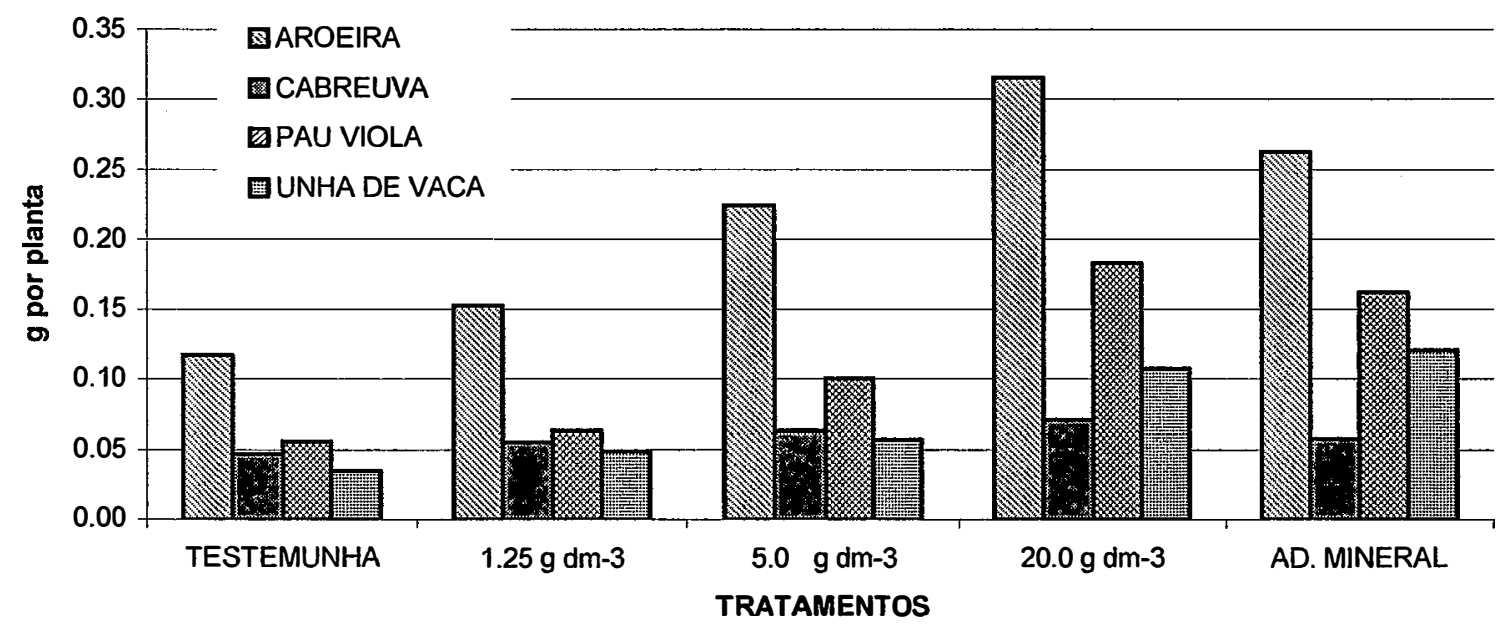

Figura 16 - Estoque de potássio nos caules das quatro espécies (g planta ${ }^{-1}$ ), em função das doses crescentes de biossólido e adubação mineral

O estoque de potássio nas raízes foi significativo para o pau-de-viola em resposta aos tratamentos de $20,0 \mathrm{~g} \mathrm{dm}^{3}$ e adubação mineral com relação a testemunha. Podemos perceber, pela Figura 17 , uma tendência de aumento no estoque de potássio nas raízes com o aumento da dose de biossólido para todas as espécies. 


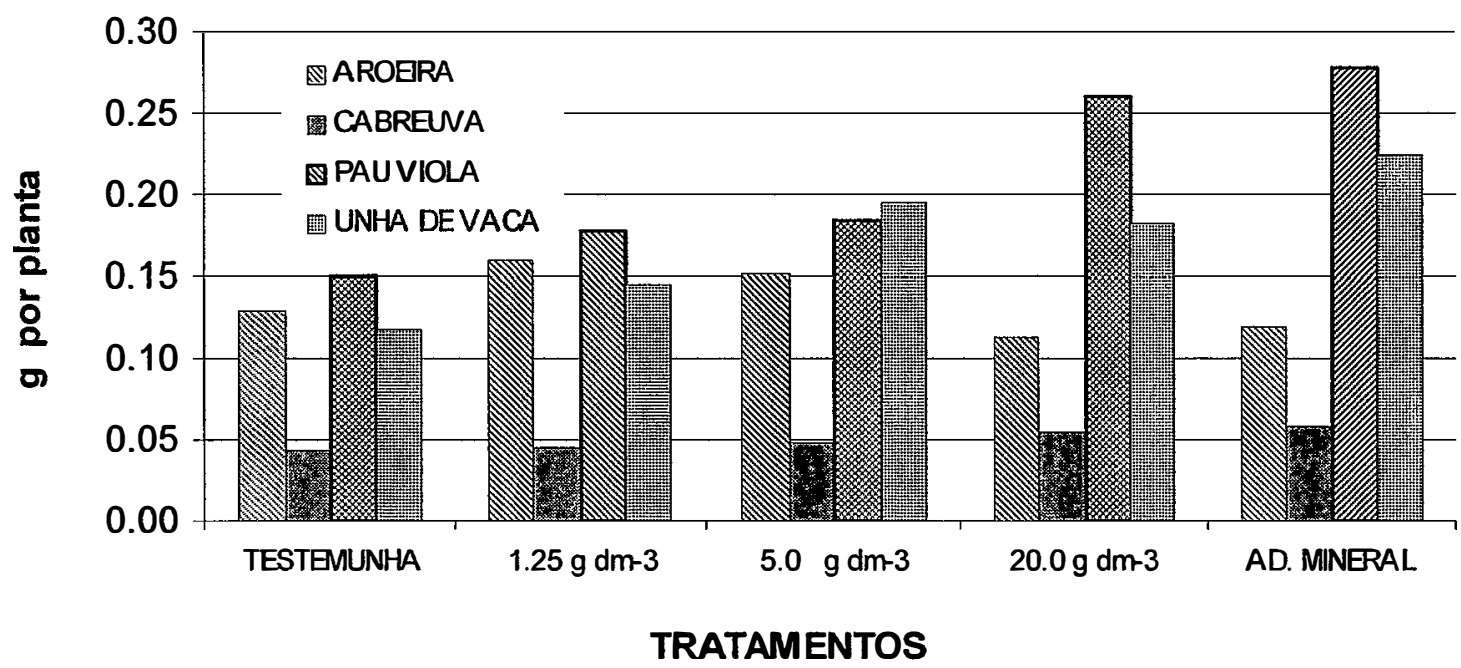

Figura 17 - Estoque de potássio nas raízes das quatro espécies (g planta ${ }^{-1}$ ), em função das doses crescentes de biossólido e adubo mineral

Pela Figura 18 , observa-se uma tendência para o aumento do estoque total de potássio nas plantas inteiras das quatro espécies, com o aumento das doses de biossólido, e uma tendência da cabreúva para estocar menos potássio do que as demais espécies. Talvez este fato possa ser explicado por ser a cabreúva uma espécie de final de sucessão. 


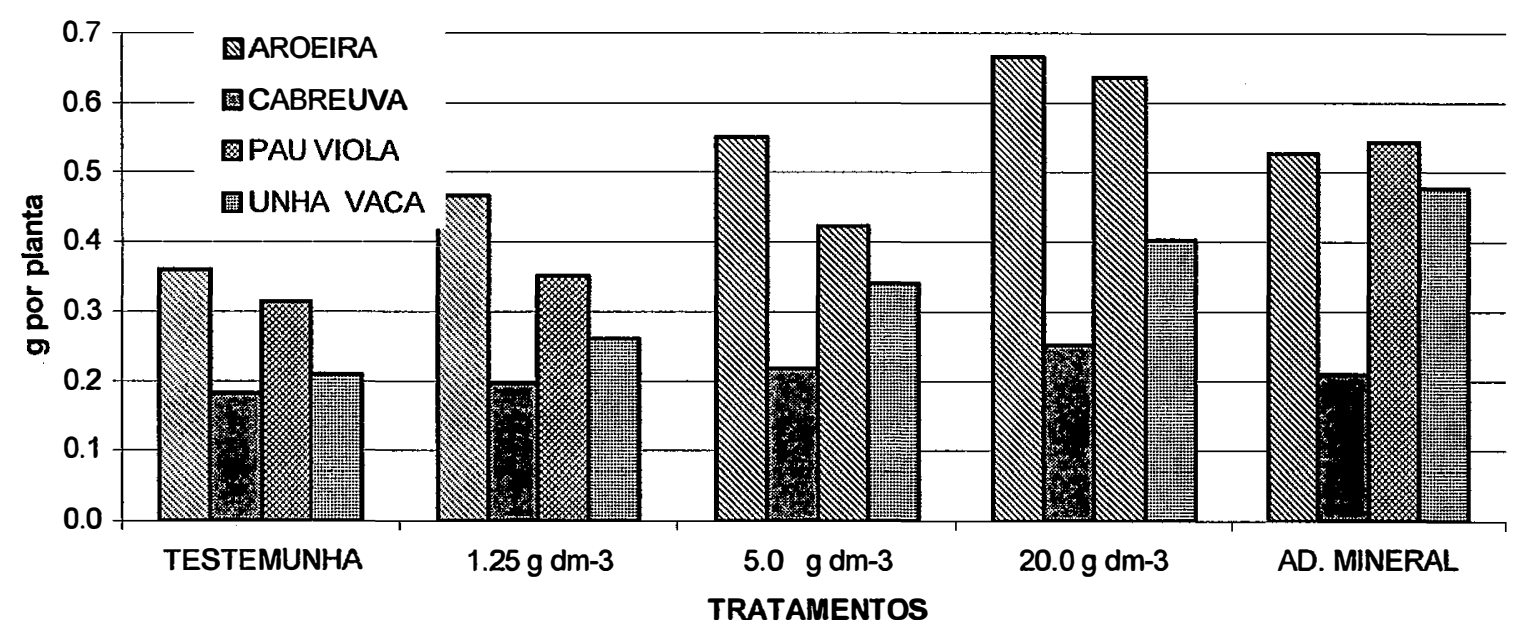

Figura 18 - Estoque total de potássio nas quatro espécies (g planta ${ }^{-1}$ ), em função das doses crescentes de biossólido e adubação mineral

Embora o estoque de potássio nos tecidos das espécies estudadas tenha aumentado com o crescimento das doses de biossólido, as concentrações ficaram abaixo das encontradas por Gonçalves et al. (1992). Portanto, este mineral deve ser suplementado em cultivos de mudas de árvores, quando se pretende utilizar o biossólido como adubo.

\subsubsection{Cálcio}

As concentrações de cálcio nas folhas e raízes das quatro espécies, em função das doses crescentes de biossólido, não apresentaram variações estatisticamente significativas em relação à testemunha $(P<0,05)$. Todos os tratamentos receberam calcário dolomítico, sendo portanto estes resultados esperados.

Entre as quatro espécies estudadas (Tabela 34), a unha-de-vaca foi a que mais concentrou cálcio em suas folhas, sendo $64 \%$ a mais que a cabreúva, $95 \%$ a mais do que o pau-de-viola e $103 \%$ a mais que a aroeira, mostrando-se 
um elemento fundamental para o desenvolvimento desta espécie. As demais espécies concentraram cálcio em quantidades estatisticamente semelhantes.

Tabela 34 . Concentração de cálcio nas folhas $\left(\mathrm{g} \mathrm{kg}^{-1}\right)$ comparando as quatro espécies, em função das doses crescentes de biossólido e da adubação mineral

\begin{tabular}{lrrrr}
\hline ESPÉCIES & $1.25 \mathrm{~g} \mathrm{dm}^{-3}$ & $5.0 \mathrm{~g} \mathrm{dm}^{-3}$ & $20.0 \mathrm{~g} \mathrm{dm}^{-3}$ & AD. MINERAL \\
\hline AROEIRA & $20.50 \mathrm{~b}$ & $19.35 \mathrm{~b}$ & $17.52 \mathrm{~b}$ & $18.82 \mathrm{~b}$ \\
CABREUVA & $21.45 \mathrm{~b}$ & $19.50 \mathrm{~b}$ & $21.67 \mathrm{~b}$ & $19.25 \mathrm{~b}$ \\
PAU-DE-VIOLA & $16.17 \mathrm{~b}$ & $16.85 \mathrm{~b}$ & $18.22 \mathrm{~b}$ & $18.00 \mathrm{~b}$ \\
UNHA-DE-VACA & $39.97 \mathrm{a}$ & $35.82 \mathrm{a}$ & $35.70 \mathrm{a}$ & $46.40 \mathrm{a}$ \\
\hline
\end{tabular}

Médias acompanhadas da mesma letra não diferem entre si pelo teste Tukey a $5 \%$.

A concentração de $\mathrm{Ca}$ nos tecidos vegetais varia de 0,02 a $5 \%$ da matéria seca, segundo Sarruge \& Haag (1974). Pela Tabela 34, observa-se valores de $1,61 \%$ a 4,6\%, indicando que as concentrações encontradas estão dentro o esperado. Gonçalves et al (1992), estudando especificamente espécies nativas, encontraram valores médios de concentração de cálcio de $13 \mathrm{~g} \mathrm{dm}^{-3}$ para pioneiras, $10 \mathrm{~g} \mathrm{dm}^{-3}$ para secundárias e $7 \mathrm{~g} \mathrm{dm}^{-3}$, próximos mas abaixo dos encontrados nesse trabalho.

As espécies que mais concentraram cálcio em suas raízes foram a aroeira, para todos os tratamentos, seguida pela unha-de-vaca e pau-de-viola. A cabreúva foi a que menos concentrou, por ser espécie de final de sucessão. Pela Tabela 35, observam-se valores entre $0,22 \%$ e 1,05\%, demonstrando uma concentração muito menor do que nas folhas. 
Tabela 35. Concentração de cálcio nas raízes $\left(\mathrm{g} \mathrm{kg}^{-1}\right)$ comparando as quatro espécies, em função das doses crescentes de biossólido e da adubação mineral

\begin{tabular}{|c|c|c|c|c|}
\hline ESPÉCIES & $1.25 \mathrm{~g} \mathrm{dm}^{-3}$ & $5.0 \mathrm{~g} \mathrm{dm}^{-3}$ & $20.0 \mathrm{~g} \mathrm{dm}^{-3}$ & AD. MINERAL \\
\hline AROEIRA & $10.50 a$ & $8.85 a$ & $8.72 a$ & $6.47 a$ \\
\hline CABREUVA & $2.22 d$ & $2.35 c$ & $2.92 b$ & $2.42 b$ \\
\hline PAU-DE-VIOLA & $4.82 \mathrm{c}$ & $3.97 \mathrm{c}$ & $4.80 \mathrm{ab}$ & $5.02 a$ \\
\hline UNHA-DE-VACA & $7.47 \mathrm{~b}$ & $6.27 \mathrm{c}$ & $6.55 a$ & $6.57 a$ \\
\hline
\end{tabular}

Médias acompanhadas da mesma letra não diferem entre si pelo teste Tukey a $5 \%$.

O estoque de $\mathrm{Ca}$ aumentou em folhas de aroeira (Tabela 36), pau-deviola e unha-de-vaca, em resposta aos tratamentos com $20,0 \mathrm{~g} \mathrm{dm}^{3}$ e adubação mineral. Em folhas de cabreúva, o estoque de Ca apresentou tendência a aumento para os mesmos tratamentos. A dosagem de $20,0 \mathrm{~g} \mathrm{dm}^{3}$ promoveu respostas iguais à adubação mineral em aroeira, cabreúva e pau-deviola, sendo menor a resposta para a unha-de-vaca,.

Tabela 36. Estoque de cálcio nas folhas das quatro espécies ( $\left(\right.$ planta $\left.^{-1}\right)$, em função das doses crescentes de biossólido e adubação mineral

\begin{tabular}{|c|c|c|c|c|c|}
\hline TRATAMENTOS & AROEIRA & CABREUVA & PAU VIOLA & \multicolumn{2}{|c|}{ UNHA VACA } \\
\hline TESTEMUNHA & & $0.27 b$ & $0.16 a$ & $0.17 b$ & $0.34 \mathrm{c}$ \\
\hline $1.25 \mathrm{~g} \mathrm{dm}-3$ & & $0.30 \mathrm{~b}$ & $0.17 a$ & $0.15 b$ & $0.36 c$ \\
\hline $5.0 \mathrm{~g} \mathrm{dm}-3$ & & $0.36 b$ & $0.17 a$ & $0.20 \mathrm{~b}$ & $0.39 c$ \\
\hline $20.0 \mathrm{~g} \mathrm{dm}-3$ & & $0.71 a$ & $0.24 a$ & $0.41 a$ & $0.54 b$ \\
\hline AD. MINERAL & & $0.79 a$ & $0.16 a$ & $0.44 a$ & $0.74 a$ \\
\hline
\end{tabular}

Médias acompanhadas da mesma letra não diferem entre si pelo teste Tukey a $5 \%$.

No caule, o estoque de Ca apresentou uma tendência de aumento com o aumento das doses de biossólido, conforme se observa na Figura 19. 


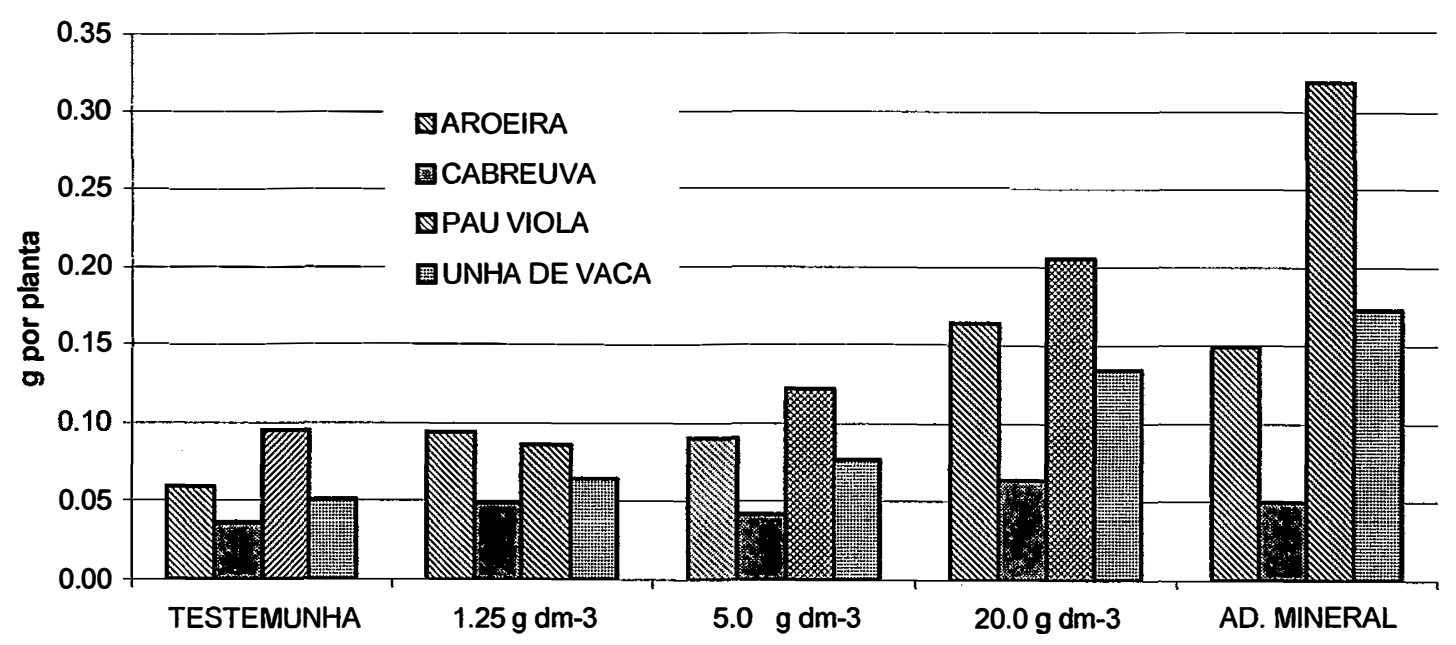

TRATAMENTOS

Figura 19 - Estoque de cálcio nos caules das quatro espécies (g planta ${ }^{-1}$ ), em função das doses crescentes de biossólido e adubação mineral

O estoque nas raízes, conforme Tabela 37 , aumentou significativamente em resposta aos tratamentos $20,0 \mathrm{~g} \mathrm{dm}^{3}$ e adubação mineral, para a aroeira, cabreúva e pau-de-viola. A unha-de-vaca apresentou tendência de aumento. A dosagem de $20,0 \mathrm{~g} \mathrm{dm}^{3}$ promoveu respostas iguais à adubação mineral em aroeira e pau-de-viola, resposta maior em cabreúva e tendência a ser igual em unha-de-vaca.

Tabela 37 . Estoque de cálcio nas raízes das quatro espécies (g planta ${ }^{-1}$ ), em função das doses crescentes de biossólido e adubação mineral

\begin{tabular}{lrrrr}
\hline TRATAMENTOS & AROEIRA & CABREUVA & PAU VIOLA & UNHA VACA \\
\hline TESTEMUNHA & $0.13 \mathrm{~b}$ & $0.016 \mathrm{~b}$ & $0.06 \mathrm{~b}$ & $0.09 \mathrm{~b}$ \\
$1.25 \mathrm{~g} \mathrm{dm}-3$ & $0.16 \mathrm{~b}$ & $0.016 \mathrm{~b}$ & $0.08 \mathrm{~b}$ & $0.10 \mathrm{~b}$ \\
$5.0 \mathrm{~g} \mathrm{dm}-3$ & $0.15 \mathrm{~b}$ & $0.017 \mathrm{~b}$ & $0.10 \mathrm{~b}$ & $0.11 \mathrm{~b}$ \\
$20.0 \mathrm{~g} \mathrm{dm}-3$ & $0.23 \mathrm{a}$ & $0.024 \mathrm{a}$ & $0.17 \mathrm{a}$ & $0.12 \mathrm{ab}$ \\
AD. MINERAL & $0.21 \mathrm{a}$ & $0.018 \mathrm{~b}$ & $0.19 \mathrm{a}$ & $0.14 \mathrm{a}$ \\
\hline
\end{tabular}

Médias acompanhadas da mesma letra não diferem entre si pelo teste Tukey a $5 \%$.

Percebe-se que apesar da calagem realizada de forma igual para todos os tratamentos, o estoque de Ca foi aumentado em resposta à dosagem de 20 
$\mathrm{g} \mathrm{dm}^{3}$ de biossólido, confirmando ser esta uma boa fonte do nutriente, mesmo sendo preparado através de processo de estabilização do lodo de esgoto com a adição de polieletrólito, mas sem a utilização de cal.

\subsubsection{Magnésio}

As concentrações de magnésio em folhas das quatro espécies podem ser observadas pela Tabela 38 . A concentração de magnésio somente foi significativa para a unha-de-vaca, sendo maior para a testemunha.

Tabela 38 .Concentrações de magnésio nas folhas $\left(\mathrm{g} \mathrm{kg}^{-1}\right)$ das quatro espécies, em função das doses crescentes de biossólido e adubação mineral

\begin{tabular}{lrrrr}
\hline TRATAMENTOS & AROEIRA & CABREUVA & PAUVIOLA & UNHA VACA \\
\hline TESTEMUNHA & $2.38 \mathrm{a}$ & $1.82 \mathrm{a}$ & $3.62 \mathrm{a}$ & $6.3 \mathrm{a}$ \\
$1.25 \mathrm{~g} \mathrm{dm}-3$ & $2.77 \mathrm{a}$ & $1.57 \mathrm{a}$ & $3.22 \mathrm{a}$ & $3.82 \mathrm{c}$ \\
$5.0 \mathrm{~g} \mathrm{dm}-3$ & $2.29 \mathrm{a}$ & $1.59 \mathrm{a}$ & $2.75 \mathrm{a}$ & $5.07 \mathrm{abc}$ \\
$20.0 \mathrm{~g} \mathrm{dm}-3$ & $1.98 \mathrm{a}$ & $1.62 \mathrm{a}$ & $3.00 \mathrm{a}$ & $4.30 \mathrm{bc}$ \\
AD. MINERAL & $2.06 \mathrm{a}$ & $1.65 \mathrm{a}$ & $3.10 \mathrm{a}$ & $3.50 \mathrm{c}$ \\
\hline Médias acompanhadas da mesma letra não diferem entre si pelo teste Tukey a $5 \%$.
\end{tabular}

Entre as espécies que mais concentraram magnésio em suas folhas (Tabela 39), a unha-de-vaca concentrou mais que as outras três espécies em resposta às duas menores dosagens de biossólido, sendo que para $20,0 \mathrm{~g} \mathrm{dm}^{3}$ e adubação mineral, teve comportamento igual ao pau-de-viola e também maior que para a aroeira e cabreúva. 
Tabela 39 .Concentrações de magnésio nas folhas $\left(\mathrm{g} \mathrm{kg}^{-1}\right)$, comparando as quatro espécies, em função das doses crescentes de biossólido e adubação mineral

\begin{tabular}{|c|c|c|c|c|c|}
\hline ESPÉCIES & $1.25 \mathrm{~g} \mathrm{dm}^{-3}$ & 5.0 & $g d^{-3}$ & $20.0 \mathrm{~g} \mathrm{dm}^{-3}$ & AD. MINERAL \\
\hline AROEIRA & $2.30 \mathrm{~b}$ & & $2.00 \mathrm{c}$ & $2.07 b$ & $2.77 b$ \\
\hline CABREUVA & $1.60 \mathrm{~b}$ & & $1.65 c$ & $1.72 b$ & $1.60 \mathrm{~b}$ \\
\hline PAU-DE-VIOLA & $2.75 b$ & & $3.00 \mathrm{~b}$ & $3.10 a$ & $3.22 a$ \\
\hline UNHA-DE-VACA & $5.07 a$ & & $4.30 a$ & $3.50 \mathrm{a}$ & $3.82 a$ \\
\hline
\end{tabular}

Médias acompanhadas da mesma letra não diferem entre si pelo teste Tukey a $5 \%$.

Segundo Sarruge \& Haag (1974), as concentrações médias de magnésio em tecidos vegetais estão entre $0,02 \%$ a $2,5 \%$ da matéria seca. Observa-se que os valores encontrados em folhas das quatro espécies estão dentro deste intervalo, indicando não haver deficiência do nutriente. Isto é atribuído à calagem com calcário dolomítico aplicado a todos os tratamentos, inclusive à testemunha, suprindo as necessidades de magnésio demandadas pelas plantas estudadas.

A concentração de magnésio em raízes de cabreúva (Tabela 40) foi maior que a testemunha apenas em resposta à dosagem de $20 \mathrm{~g} \mathrm{dm}^{-3}$, sendo a única das quatro espécies com diferenças significativas. Isto pode ser explicado por ser espécie de final de sucessão, tendo produzido menor quantidade de matéria seca que as demais espécies em resposta às doses crescentes de biossólido e adubo mineral, não apresentando efeito de diluição do nutriente.

Tabela 40 .Concentrações de magnésio nas raízes $\left(\mathrm{g} \mathrm{kg}^{-1}\right)$ das quatro espécies, em função das doses crescentes de biossólido e adubação mineral

\begin{tabular}{lrrrr}
\hline TRATAMENTOS & AROEIRA & CABREUVA & PAU VIOLA & UNHA VACA \\
\hline TESTEMUNHA & $1.37 \mathrm{a}$ & $0.70 \mathrm{~b}$ & $1.55 \mathrm{a}$ & $4.02 \mathrm{a}$ \\
$1.25 \mathrm{~g} \mathrm{dm}-3$ & $1.44 \mathrm{a}$ & $0.47 \mathrm{~b}$ & $1.61 \mathrm{a}$ & $4.3 \mathrm{a}$ \\
$5.0 \mathrm{~g} \mathrm{dm}-3$ & $1.19 \mathrm{a}$ & $0.57 \mathrm{~b}$ & $1.34 \mathrm{a}$ & $3.54 \mathrm{a}$ \\
$20.0 \mathrm{~g} \mathrm{dm}-3$ & $1.34 \mathrm{a}$ & $1.02 \mathrm{a}$ & $1.87 \mathrm{a}$ & $3.69 \mathrm{a}$ \\
AD. MINERAL & $1.12 \mathrm{a}$ & $0.65 \mathrm{~b}$ & $1.19 \mathrm{a}$ & $3.32 \mathrm{a}$
\end{tabular}

Médias acompanhadas da mesma letra não diferem entre si pelo teste Tukey a $5 \%$. 
A quantidade de magnésio acumulada nas folhas das quatro espécies pode ser vista pela Tabela 41. Observa-se na aroeira e pau-de-viola aumento no estoque de magnésio em resposta aos tratamentos com $20,0 \mathrm{~g} \mathrm{dm}^{3}$ e adubação mineral com relação à testemunha. As duas outras espécies não apresentaram diferenças significativas entre os tratamentos.

Tabela 41 .Estoque de magnésio nas folhas ( $\left.\mathrm{g}_{\text {planta }}{ }^{-1}\right)$ das quatro espécies , em função das doses crescentes de biossólido e adubação mineral

\begin{tabular}{lrrrr}
\hline TRATAMENTOS & AROEIRA & CABREUVA & PAU VIOLA & UNHA VACA \\
\hline TESTEMUNHA & $0.033 \mathrm{c}$ & $0.014 \mathrm{a}$ & $0.036 \mathrm{~b}$ & $0.053 \mathrm{a}$ \\
$1.25 \mathrm{~g} \mathrm{dm}-3$ & $0.034 \mathrm{c}$ & $0.013 \mathrm{a}$ & $0.026 \mathrm{~b}$ & $0.046 \mathrm{a}$ \\
$5.0 \mathrm{~g} \mathrm{dm}-3$ & $0.037 \mathrm{c}$ & $0.014 \mathrm{a}$ & $0.037 \mathrm{~b}$ & $0.048 \mathrm{a}$ \\
$20.0 \mathrm{~g} \mathrm{dm}-3$ & $0.083 \mathrm{~b}$ & $0.018 \mathrm{a}$ & $0.070 \mathrm{a}$ & $0.052 \mathrm{a}$ \\
AD. MINERAL & $0.117 \mathrm{a}$ & $0.013 \mathrm{a}$ & $0.079 \mathrm{a}$ & $0.059 \mathrm{a}$
\end{tabular}

Médias acompanhadas da mesma letra não diferem entre si pelo teste Tukey a $5 \%$.

Entre as espécies, percebe-se, pela Tabela 42, diferenças significativas de estoque. Para as doses de $20,0 \mathrm{~g} \mathrm{dm}^{3}$ de biossólido e adubação mineral, a aroeira acumulou mais magnésio do que as outras três espécies. $O$ pau-deviola e a unha-de-vaca estocaram quantidades estatisticamente iguais, já a cabreúva foi a que menos estocou, seguindo a lógica da sucessão vegetal, onde as espécies de início de sucessão estocam mais que as de final de sucessão.

Tabela 42 .Estoque de magnésio nas folhas $\left(\mathrm{g}\right.$ planta $\left.^{-1}\right)$ comparando as quatro espécies, em função das doses crescentes de biossólido e adubação mineral

\begin{tabular}{|c|c|c|c|c|}
\hline ESPÉCIES & $1.25 \mathrm{~g} \mathrm{dm}-3$ & $5.0 \mathrm{~g} \mathrm{dm}-3$ & $20.0 \mathrm{~g} \mathrm{dm}-3$ & AD. MINERAL \\
\hline AROEIRA & $0.034 \mathrm{c}$ & $0.037 \mathrm{~b}$ & $0.084 a$ & $0.120 a$ \\
\hline CABREUVA & $0.013 b$ & $0.014 c$ & $0.019 c$ & $0.010 c$ \\
\hline PAU-DE-VIOLA & $0.026 b$ & $0.037 \mathrm{~b}$ & $0.070 \mathrm{~b}$ & $0.070 \mathrm{~b}$ \\
\hline UNHA-DE-VACA & $0.046 a$ & $0.048 a$ & $0.053 \mathrm{~b}$ & $0.060 \mathrm{~b}$ \\
\hline
\end{tabular}


O estoque de magnésio nas raízes das quatro espécies pode ser visto pela Tabela 43. Os tratamentos com $20,0 \mathrm{~g} \mathrm{dm}^{3}$ e adubação mineral aumentaram o estoque de magnésio na aroeira e pau-de-viola. A dose de 20,0 $\mathrm{g} \mathrm{dm}^{3}$ promoveu uma tendência de aumento na cabreúva. A unha-de-vaca não foi influenciada pelos tratamentos.

Tabela 43 .Estoque de magnésio nas raizes $\left(\mathrm{g}_{\text {planta }}{ }^{-1}\right)$ das quatro espécies , em função das doses crescentes de biossólido e adubação mineral

\begin{tabular}{lrrrr}
\hline TRATAMENTOS & AROEIRA & CABREUVA & PAUVIOLA & UNHA VACA \\
\hline TESTEMUNHA & $0.019 \mathrm{~b}$ & $0.005 \mathrm{~b}$ & $0.024 \mathrm{c}$ & $0.048 \mathrm{a}$ \\
$1.25 \mathrm{~g} \mathrm{dm}-3$ & $0.023 \mathrm{~b}$ & $0.003 \mathrm{~b}$ & $0.026 \mathrm{c}$ & $0.059 \mathrm{a}$ \\
$5.0 \mathrm{~g} \mathrm{dm}-3$ & $0.021 \mathrm{~b}$ & $0.004 \mathrm{~b}$ & $0.035 \mathrm{c}$ & $0.063 \mathrm{a}$ \\
$20.0 \mathrm{~g} \mathrm{dm}-3$ & $0.036 \mathrm{a}$ & $0.008 \mathrm{ab}$ & $0.069 \mathrm{a}$ & $0.068 \mathrm{a}$ \\
AD. MINERAL & $0.036 \mathrm{a}$ & $0.005 \mathrm{~b}$ & $0.047 \mathrm{bc}$ & $0.072 \mathrm{a}$ \\
\hline
\end{tabular}

Médias acompanhadas da mesma letra não diferem entre si pelo teste Tukey a $5 \%$.

Entre as espécies (Tabela 44), a unha-de-vaca e o pau-de-viola acumularam mais magnésio nas raízes do que as outras duas espécies em resposta aos tratamentos de $20,0 \mathrm{~g} \mathrm{dm}^{3}$ de biossólido e adubação mineral, seguidas pela aroeira. A cabreúva foi a que estocou menos magnésio, confirmando a tendência das espécies arbóreas ao menor uso e menor acúmulo de nutrientes na medida em que se avança nos estágios sucessionais.

Tabela 44 .Estoque de magnésio em raizes $\left(\mathrm{g} \mathrm{kg}^{-1}\right)$ comparando as quatro espécies, em função das doses crescentes de biossólido e adubação mineral

\begin{tabular}{|c|c|c|c|c|}
\hline ESPÉCIES & $1.25 \mathrm{~g} \mathrm{dm}-3$ & $g d m-3$ & $20.0 \mathrm{~g} \mathrm{dm}-3$ & AD. MINERAL \\
\hline AROEIRA & $0.023 b$ & $0.021 b$ & $0.036 b$ & $0.036 b$ \\
\hline CABREUVA & $0.003 c$ & $0.004 c$ & $0.008 \mathrm{c}$ & $0.005 c$ \\
\hline PAU-DE-VIOLA & $0.026 \mathrm{~b}$ & $0.035 b$ & $0.069 a$ & $0.047 a$ \\
\hline UNHA-DE-VACA & $0.060 a$ & $0.064 a$ & $0.069 a$ & $0.072 a$ \\
\hline
\end{tabular}

Médias acompanhadas da mesma letra não diferem entre si pelo teste Tukey a $5 \%$.

O estoque de magnésio nos caules de todas as espécies (Figura 20), apresenta uma tendência de aumento com as doses crescentes de biossólido e 
adubo mineral. Percebe-se uma tendência nítida de maior estoque nas espécies de início de sucessão. Também percebe-se que o estoque no caule tem uma tendência de se manter em niveis menores do que nas raízes e folhas.

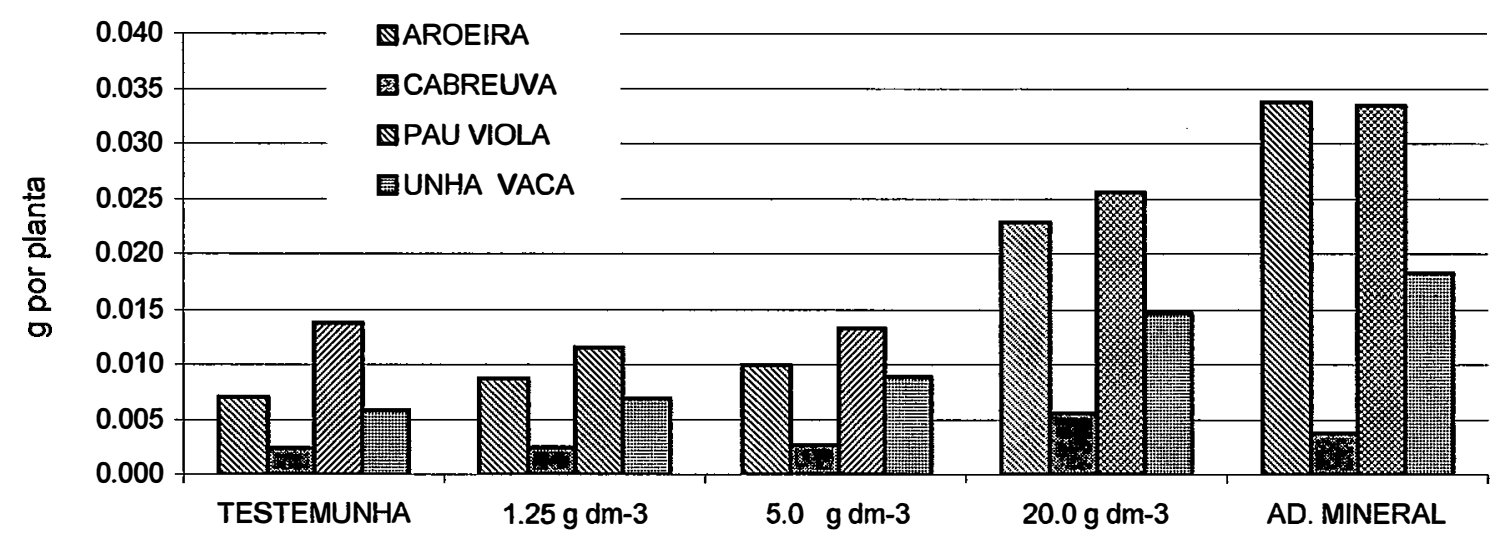

TRATAMENTOS

Figura 20 - Estoque de magnésio nos caules das quatro espécies(g planta $\left.{ }^{-1}\right)$, em função das doses crescentes de biossólido e adubação mineral

A Figura 21 mostra o estoque total de magnésio na planta inteira, onde se observa uma tendência ao acúmulo maior pelas espécies de início de sucessão, como aroeira, pau-de-viola e unha-de-vaca, e menor nas de final de sucessão, como na cabreúva. Também se observa tendência ao aumento de estoque com o aumento das doses de biossólido e adubação mineral. 


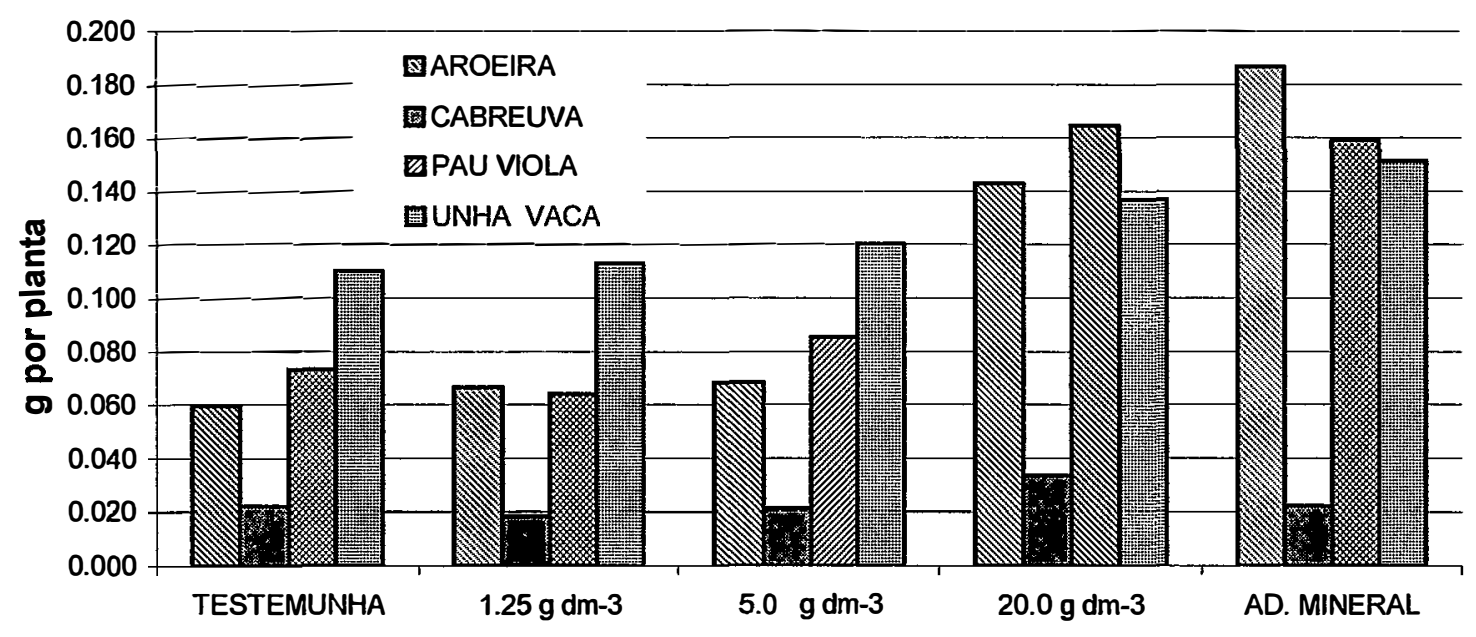

TRATAMENTOS

Figura 21 - Estoque total de magnésio nas quatro espécies (g planta ${ }^{-1}$ ), em função das doses crescentes de biossólido e adubação mineral

\subsubsection{Enxofre}

As concentrações de enxofre nas quatro espécies, tanto nas folhas quanto em raízes, não apresentaram diferenças estatisticamente significativas entre os tratamentos, devido às variâncias desiguais e elevadas $(P<0,05)$, conforme Tabelas 45 e 46.

As concentrações médias de enxofre em tecidos de plantas variam de 0,1 a 1,5\% da matéria seca, segundo Sarruge \& Haag (1974). Observa-se que a maioria dos valores médios encontrados estão dentro deste intervalo, porém existem valores abaixo, indicando deficiência de enxofre. Percebe-se uma tendência à variações de concentração entre as espécies, indicando utilização diferenciada do nutriente, embora não exista um padrão lógico que possa explicar esse comportamento. 
Tabela 45. Concentração de enxofre nas folhas $\left(\mathrm{g} \mathrm{kg}^{-1}\right)$ das quatro espécies , em função das doses crescentes de biossólido e adubação mineral

\begin{tabular}{lrrrr}
\hline TRATAMENTOS & AROEIRA & CABREUVA & PAU VIOLA & UNHA-DE-VACA \\
\hline TESTEMUNHA & 2.55 & 0.80 & 3.27 & 0.75 \\
$1.25 \mathrm{~g} \mathrm{dm}-3$ & 1.77 & 1.25 & 1.60 & 1.27 \\
$5.0 \mathrm{~g} \mathrm{dm}-3$ & 1.62 & 0.80 & 3.32 & 0.70 \\
$20.0 \mathrm{~g} \mathrm{dm}-3$ & 2.85 & 0.80 & 3.55 & 2.97 \\
AD. MINERAL & 1.85 & 1.07 & 3.30 & 0.95 \\
\hline
\end{tabular}

Percebe-se uma tendência à maior concentração de enxofre nas folhas das quatro espécies em resposta à dose de $20 \mathrm{~g} \mathrm{dm}^{3}$ de biossólido. A adubação mineral promoveu tendência a um menor acúmulo de enxofre nas folhas do que a dose de $20 \mathrm{~g} \mathrm{dm}^{3}$ de biossólido, excetuando-se a cabreúva. Nas raízes promoveu uma tendência à redução na concentração de enxofre com o aumento da dose de biossólido, excetuando-se a unha-de-vaca. Houve uma tendência de aumento na concentração de enxofre nas raízes das quatro espécies em resposta à adubação mineral com relação à dose de $20 \mathrm{~g} \mathrm{dm}^{3} \mathrm{de}$ biossólido.

Tabela 46 .Concentração de enxofre nas raízes $\left(\mathrm{g} \mathrm{kg}^{-1}\right)$ das quatro espécies, em função das doses crescentes de biossólido e adubação mineral

\begin{tabular}{lrrrr}
\hline TRATAMENTOS & AROEIRA & CABREUVA & PAU VIOLA & UNHA-DE-VACA \\
\hline TESTEMUNHA & 1.20 & 0.60 & 1.45 & 1.20 \\
$1.25 \mathrm{~g} \mathrm{dm}-3$ & 1.27 & 1.45 & 2.55 & 3.00 \\
$5.0 \mathrm{~g} \mathrm{dm}-3$ & 1.05 & 0.85 & 1.42 & 1.17 \\
$20.0 \mathrm{~g} \mathrm{dm}-3$ & 0.60 & 0.40 & 0.87 & 1.40 \\
AD. MINERAL & 1.87 & 0.80 & 1.40 & 2.20 \\
\hline
\end{tabular}

Também podem-se observar comportamentos diferenciados na alocação do nutriente nas folhas e raízes entre as quatro espécies (Figura 22). Observase uma tendência de aumento na concentração de enxofre nas folhas, com o aumento das doses de biossólido, em detrimento das raízes. A unha-de-vaca 
exibe uma tendência a concentrar mais enxofre nas raízes que as demais espécies. A aroeira e o pau-de-viola exibem tendência a concentrar mais enxofre na parte aérea. A cabreúva se mantém numa posição intermediária. Todas as espécies tenderam a alocar mais enxofre nas raízes em resposta à adubação mineral.

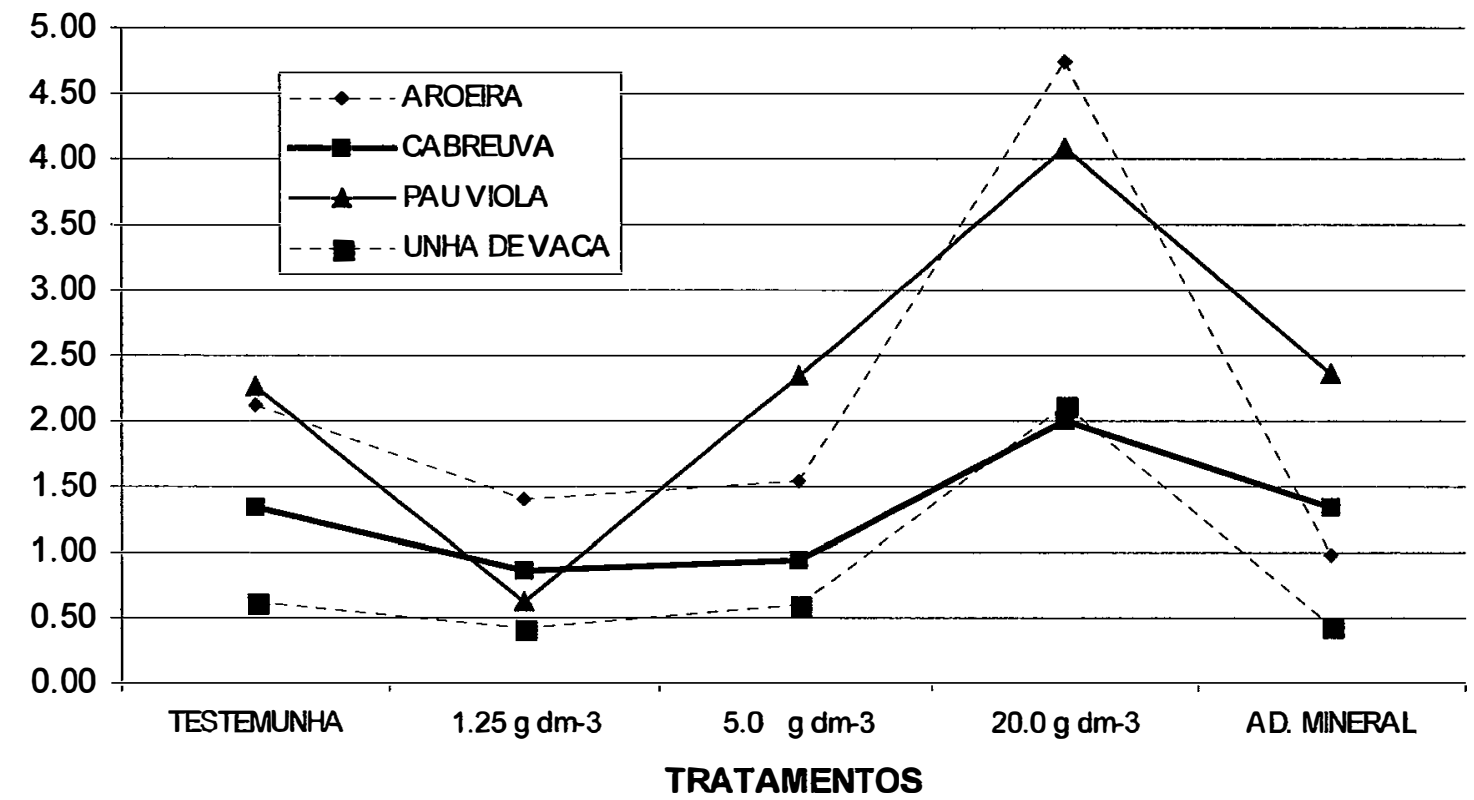

Figura 22 - Relação entre as concentrações de enxofre nas folhas e raízes nas quatro espécies, em função das doses crescentes de biossólido e adubação mineral

A Figura 23 exibe uma tendência para o aumento do estoque total de enxofre com as doses crescentes de biossólido. Também exibe tendência a estoque diferenciado entre as espécies, sendo maior nas espécies de início de sucessão (aroeira, pau-de-viola e unha-de-vaca) e menor nas de final de sucessão (cabreúva). A dose de $20 \mathrm{~g} \mathrm{dm}^{3}$ mostra uma tendência de resposta ao acúmulo total de enxofre próxima à da adubação mineral. 


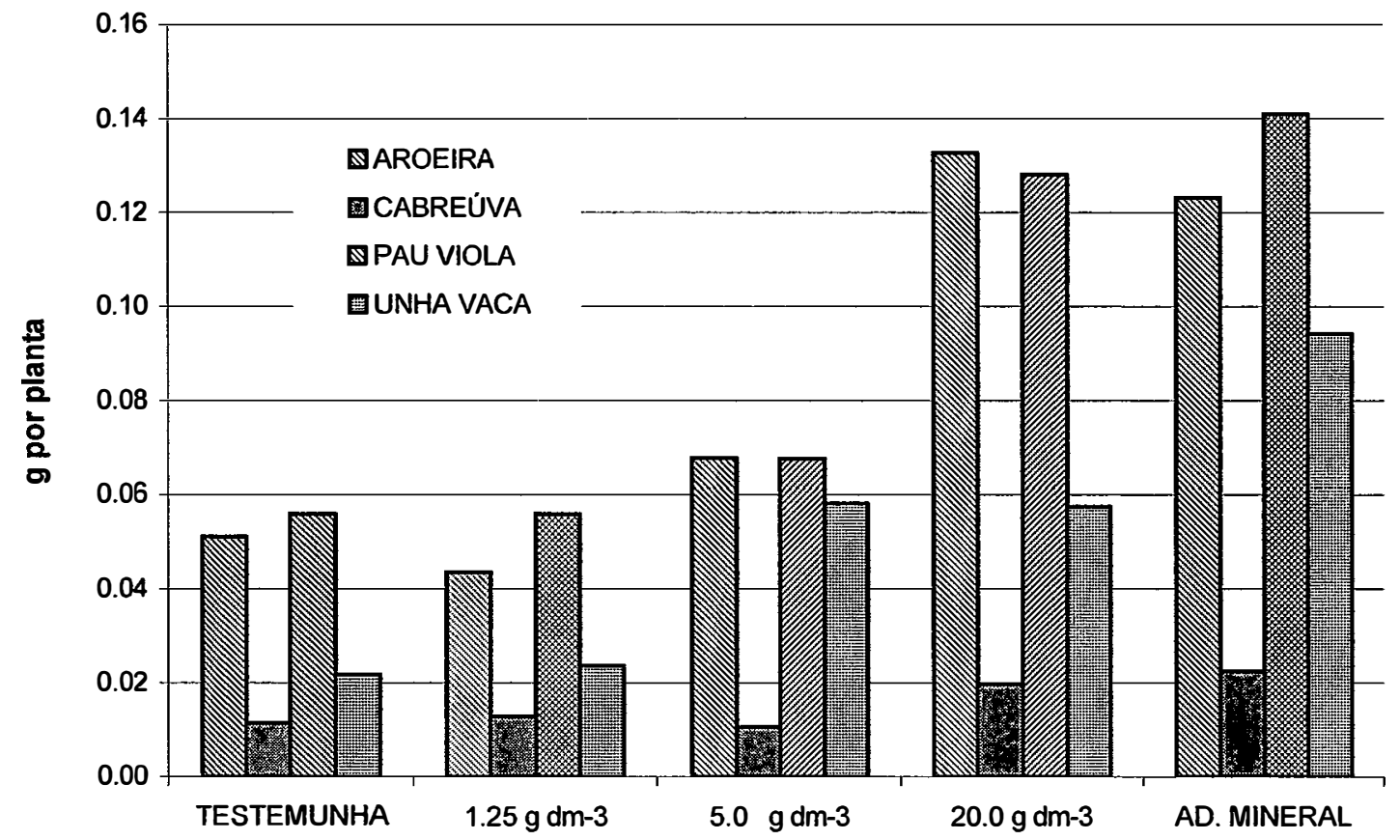

TRATAMENTOS

Figura 23 - Estoque total de enxofre nas quatro espécies (g planta ${ }^{-1}$ ), em função das doses crescentes de biossólido e adubação mineral 


\subsubsection{Boro}

As concentrações de boro em folhas das quatro espécies exibidas pela Figura 24, apresentam uma tendência à redução com o aumento das doses de biossólido, encontrando-se na faixa de 10 a $30 \mathrm{mg} \mathrm{kg}^{-1}$ e uma tendência de aumento em resposta à adubação mineral. Kabata-Pendias et al. (1986) indicam deficiência de $B$ nas folhas com concentrações entre 5 e $30 \mathrm{mg} \mathrm{kg}^{-1} \mathrm{e}$ níveis normais entre 10 e $200 \mathrm{mg} \mathrm{kg}^{-1}$. Percebem-se concentrações entre o intervalo de deficiência e limite inferior de concentrações normais.

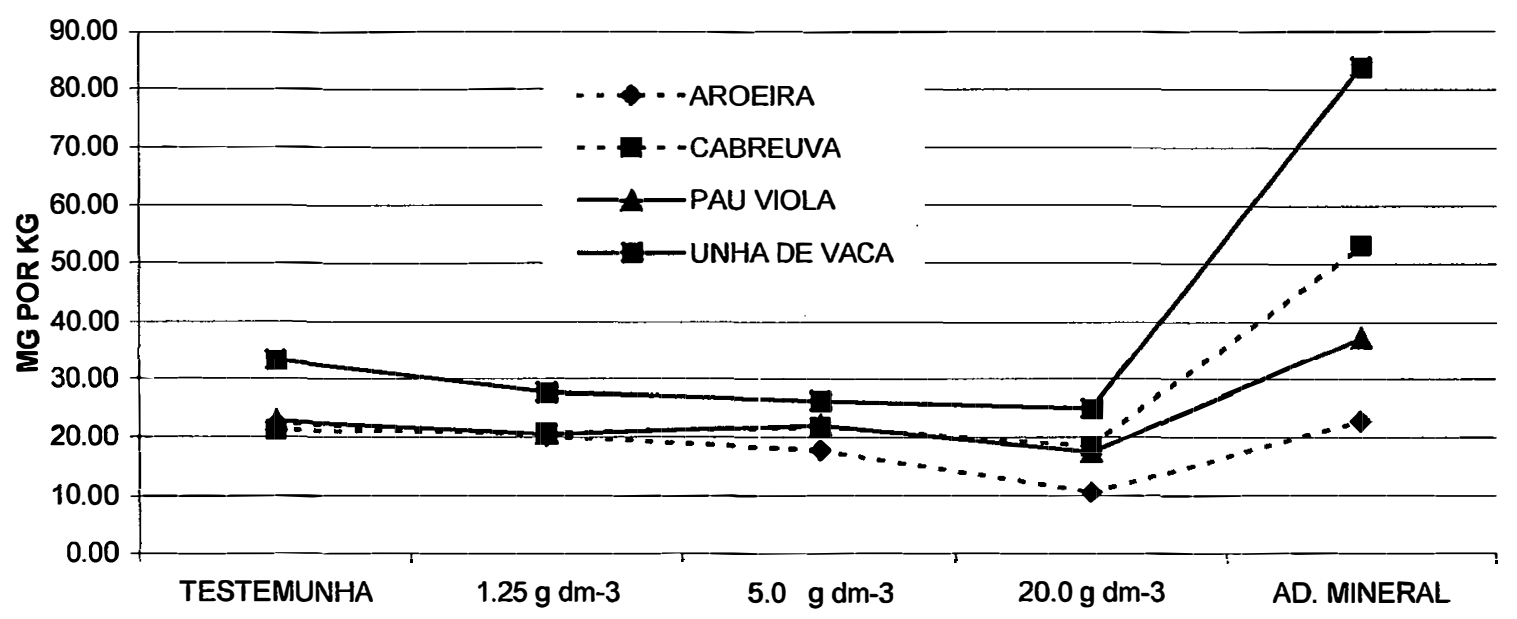

TRATAMENTOS

Figura 24 - Concentração de boro nas folhas das quatro espécies $\left(\mathrm{mg} \mathrm{kg}^{-1}\right)$, em função das doses crescentes de biossólido e adubação mineral

Nas raízes, não houve diferenças estatisticamente significativas para a concentração de boro pelas variâncias desiguais $(p<0,05)$, encontrando-se em uma faixa de 10 a $25 \mathrm{mg} \mathrm{kg}^{-1}$, conforme Figura 25 . 


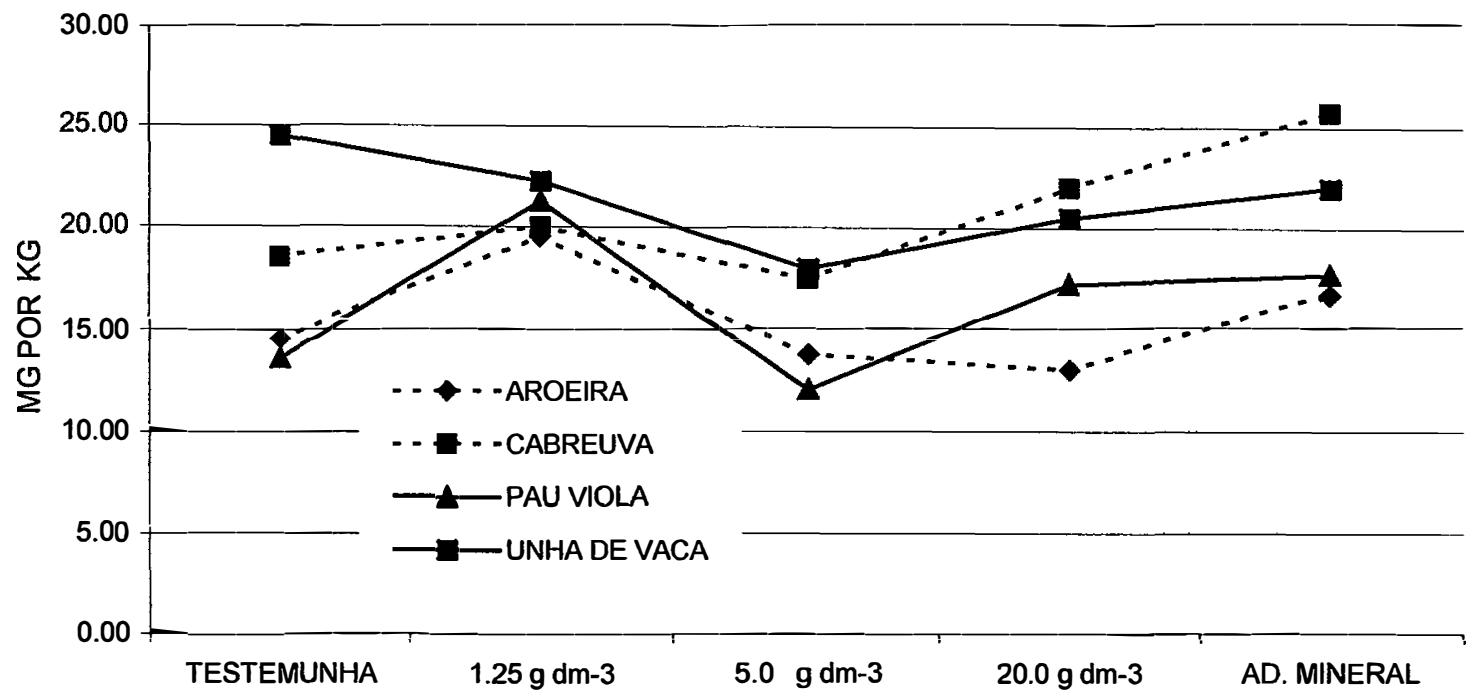

TRATAMENTOS

Figura 25 - Concentração de boro nas raízes das quatro espécies $\left(\mathrm{mg} \mathrm{kg}^{-1}\right)$, em função das doses crescentes de biossólido e adubação mineral

O estoque de boro nas folhas das quatro espécies, observado pela Tabela 47, exibe valores estatisticamente significativos com relação à testemunha em resposta à adubação mineral para todas as espécies e valores não significativos para os tratamentos com biossólido, demonstrando não ser boa fonte deste nutriente.

Tabela 47 . Estoque de boro nas folhas ( $\mathrm{mg} \mathrm{planta}^{-1}$ ) das quatro espécies, em função das doses crescentes de biossólido e adubação mineral

\begin{tabular}{lrrrr}
\hline TRATAMENTOS & AROEIRA & CABREUVA & PAU VIOLA & UNHA VACA \\
\hline TESTEMUNHA & $0.29 \mathrm{~b}$ & $0.17 \mathrm{~b}$ & $0.22 \mathrm{~b}$ & $0.28 \mathrm{~b}$ \\
$1.25 \mathrm{~g} \mathrm{dm}-3$ & $0.30 \mathrm{~b}$ & $0.17 \mathrm{~b}$ & $0.20 \mathrm{~b}$ & $0.25 \mathrm{~b}$ \\
$5.0 \mathrm{~g} \mathrm{dm}-3$ & $0.34 \mathrm{~b}$ & $0.19 \mathrm{~b}$ & $0.27 \mathrm{~b}$ & $0.29 \mathrm{~b}$ \\
$20.0 \mathrm{~g} \mathrm{dm}-3$ & $0.42 \mathrm{~b}$ & $0.20 \mathrm{~b}$ & $0.39 \mathrm{~b}$ & $0.38 \mathrm{~b}$ \\
AD. MINERAL & $0.95 \mathrm{a}$ & $0.44 \mathrm{a}$ & $0.91 \mathrm{a}$ & $1.35 \mathrm{a}$ \\
\hline
\end{tabular}

Médias acompanhadas da mesma letra não diferem entre si pelo teste Tukey a $5 \%$. 
O estoque de boro nas raízes apresentou resultados estatisticamente significativos em resposta à dosagem de $20,00 \mathrm{~g} \mathrm{dm}^{3}$ de biossólido para o paude-viola e à adubação mineral para a aroeira e pau-de-viola, não sendo significativo para cabreúva e unha-de-vaca, conforme Tabela 48 .

Tabela 48 . Estoque de boro nas raízes $\left(\mathrm{mg} \mathrm{planta}^{-1}\right)$ das quatro espécies, em função das doses crescentes de biossólido e adubação mineral

\begin{tabular}{lrrrr}
\hline TRATAMENTOS & AROEIRA & CABREUVA & PAU VIOLA & UNHA VACA \\
\hline TESTEMUNHA & $0.20 \mathrm{~b}$ & $0.13 \mathrm{a}$ & $0.21 \mathrm{~b}$ & $0.28 \mathrm{a}$ \\
$1.25 \mathrm{~g} \mathrm{dm}-3$ & $0.30 \mathrm{~b}$ & $0.14 \mathrm{a}$ & $0.37 \mathrm{~b}$ & $0.29 \mathrm{a}$ \\
$5.0 \mathrm{~g} \mathrm{dm}-3$ & $0.24 \mathrm{~b}$ & $0.12 \mathrm{a}$ & $0.29 \mathrm{~b}$ & $0.32 \mathrm{a}$ \\
$20.0 \mathrm{~g} \mathrm{dm}-3$ & $0.35 \mathrm{~b}$ & $0.17 \mathrm{a}$ & $0.64 \mathrm{a}$ & $0.37 \mathrm{a}$ \\
AD. MINERAL & $0.54 \mathrm{a}$ & $0.19 \mathrm{a}$ & $0.69 \mathrm{a}$ & $0.46 \mathrm{a}$ \\
\hline
\end{tabular}

Médias acompanhadas da mesma letra não diferem entre si pelo teste Tukey a $5 \%$.

\subsubsection{Cobre}

As concentrações de cobre nas folhas da cabreúva, pau-de-viola e unha-de-vaca não se diferenciaram significativamente entre si em resposta aos tratamentos (Tabela 49). A unha-de-vaca e o pau-de-viola apresentaram tendência à redução na concentração em resposta à adubação mineral, por efeito de diluição do nutriente na maior quantidade de matéria seca produzida em resposta ao tratamento. A aroeira concentrou menos cobre em resposta ao tratamento com adubação mineral e tendência à redução de concentração em resposta às doses de $5,0 \mathrm{~g} \mathrm{dm}^{3}, 20 \mathrm{~g} \mathrm{dm}^{3}$ de biossólido. Kabata-Pendias et al. (1986) indicam deficiência de Cu para concentrações entre 2 e $5 \mathrm{mg} \mathrm{kg}^{-1}$ e valores suficientes entre 5 e $30 \mathrm{mg} \mathrm{kg}^{-1}$. Observamos concentração na faixa de deficiência apenas para a aroeira em resposta à adubação mineral, o que pode ser explicado por um efeito de diluição do cobre na matéria seca da espécie. 
Tabela 49 . Concentração de cobre nas folhas $\left(\mathrm{mg} \mathrm{kg}^{-1}\right)$ das quatro espécies, em função das doses crescentes de biossólido e adubação mineral

\begin{tabular}{lrrrr}
\hline TRATAMENTOS & AROEIRA & CABREUVA & PAU VIOLA & UNHA VACA \\
\hline TESTEMUNHA & $7.25 \mathrm{a}$ & $10.71 \mathrm{a}$ & $7.25 \mathrm{a}$ & $7.25 \mathrm{a}$ \\
$1.25 \mathrm{~g} \mathrm{dm}-3$ & $7.00 \mathrm{a}$ & $8.74 \mathrm{a}$ & $8.25 \mathrm{a}$ & $10.00 \mathrm{a}$ \\
$5.0 \mathrm{~g} \mathrm{dm}-3$ & $8.00 \mathrm{ab}$ & $10.49 \mathrm{a}$ & $9.25 \mathrm{a}$ & $10.25 \mathrm{a}$ \\
$20.0 \mathrm{~g} \mathrm{dm}-3$ & $5.25 \mathrm{ab}$ & $9.19 \mathrm{a}$ & $8.25 \mathrm{a}$ & $9.50 \mathrm{a}$ \\
AD. MINERAL & $4.50 \mathrm{~b}$ & $8.57 \mathrm{a}$ & $5.50 \mathrm{ab}$ & $5.50 \mathrm{ab}$ \\
\hline
\end{tabular}

Médias acompanhadas da mesma letra não diferem entre si pelo teste Tukey a 5\%.

As quatro espécies concentraram maiores quantidades de cobre em suas raízes em resposta ao tratamento com $20 \mathrm{~g} \mathrm{dm}^{3}$ de biossólido. Observa-se pela Tabela 50 , que a aroeira concentrou 4,89 vezes mais, a cabreúva 2,49 vezes mais, o pau-de-viola 2,82 vezes mais e a unha-de-vaca 2,97 vezes mais cobre que a testemunha em resposta à dosagem de $20 \mathrm{~g} \mathrm{dm}^{3}$ de biossólido, demonstrando ser o biossólido excelente fonte de cobre. A cabreúva concentrou menos cobre com relação às outras três espécies. Os niveis fitotóxicos de $\mathrm{Cu}$ em plantas variam de 60 a $125 \mathrm{mg} \mathrm{kg}^{-1}$, segundo Melo et al. citado por Marques et al. (2001), estando as concentrações nas raízes de aroeira, pau-de-viola e unha-de-vaca em resposta ao tratamento de $20,0 \mathrm{~g} \mathrm{dm}^{-3}$ dentro da faixa, mas próximas ao limite mínimo.

Tabela 50 . Concentração de cobre nas raízes $\left(\mathrm{mg} \mathrm{kg}^{-1}\right)$ das quatro espécies, em função das doses crescentes de biossólido e adubação mineral

\begin{tabular}{lrrrr}
\hline TRATAMENTOS & AROEIRA & CABREUVA & PAU VIOLA & UNHA VACA \\
\hline TESTEMUNHA & $16.00 \mathrm{~b}$ & $12.75 \mathrm{~b}$ & $24.50 \mathrm{~b}$ & $22.50 \mathrm{~b}$ \\
$1.25 \mathrm{~g} \mathrm{dm}-3$ & $17.25 \mathrm{~b}$ & $11.25 \mathrm{~b}$ & $32.25 \mathrm{~b}$ & $29.50 \mathrm{~b}$ \\
$5.0 \mathrm{~g} \mathrm{dm}-3$ & $24.25 \mathrm{~b}$ & $18.75 \mathrm{~b}$ & $35.75 \mathrm{~b}$ & $26.50 \mathrm{~b}$ \\
$20.0 \mathrm{~g} \mathrm{dm}-3$ & $78.25 \mathrm{a}$ & $31.75 \mathrm{a}$ & $69.25 \mathrm{a}$ & $66.75 \mathrm{a}$ \\
AD. MINERAL & $15.25 \mathrm{~b}$ & $24.00 \mathrm{~b}$ & $19.25 \mathrm{~b}$ & $28,00 \mathrm{~b}$ \\
\hline
\end{tabular}

Médias acompanhadas da mesma letra não diferem entre si pelo teste Tukey a $5 \%$. 
A relação das concentrações de cobre entre folhas e raízes tendeu a reduzir-se com o aumento da dose de biossólido, mostrando uma maior concentração de $\mathrm{Cu}$ em raízes (Figura 26). A cabreúva tendeu a concentrar mais cobre em suas folhas do que nas raizes, sendo que as outras três espécies tenderam a concentrar mais este elemento em suas raízes.

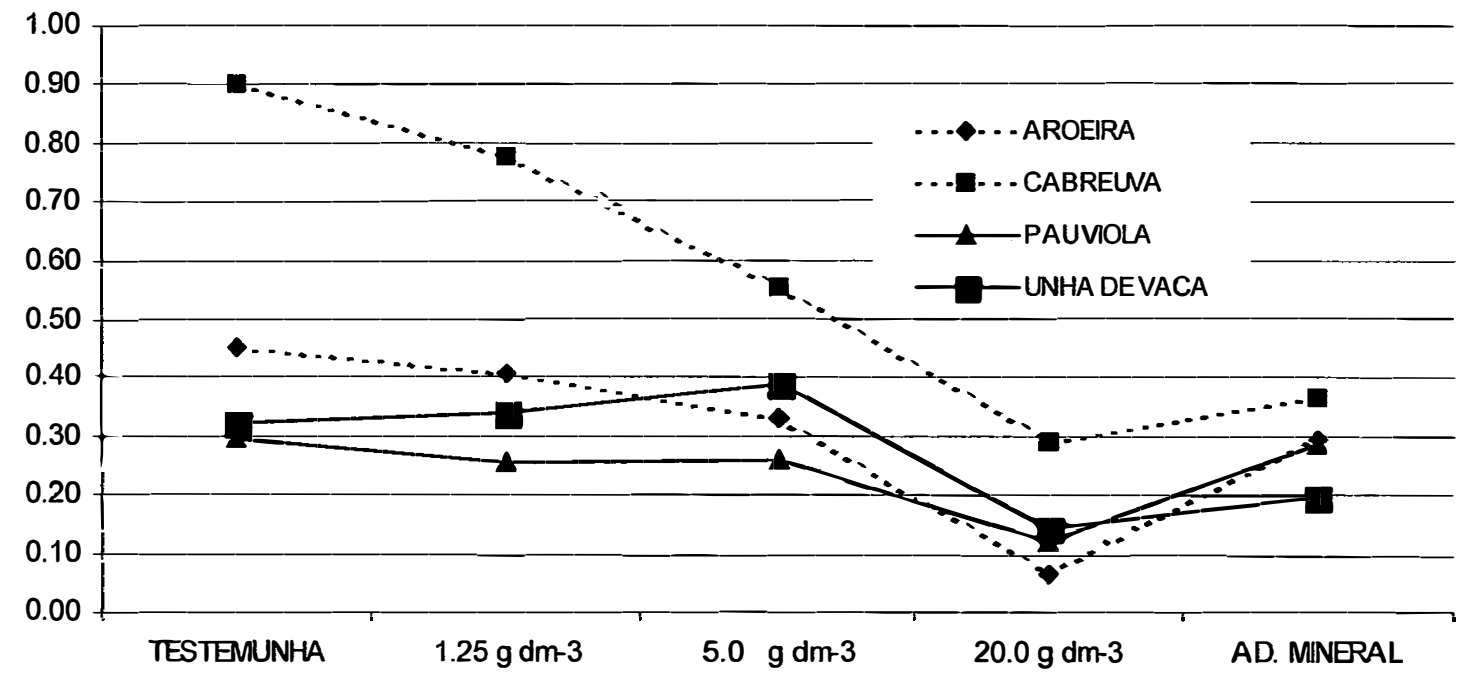

TRATAMENTOS

Figura 26 - Relação das concentrações de cobre entre folhas e raízes das quatro espécies, em função das doses crescentes de biossólido e adubação mineral

Observando-se pela Tabela 51 as quantidades de cobre estocadas na biomassa, nota-se que a aroeira estocou mais em suas folhas que a testemunha, em resposta aos tratamentos de $20,00 \mathrm{~g} \mathrm{dm}^{3}$ de biossólido e à adubação mineral, não diferenciando estatisticamente entre si. As outras três espécies não foram influenciadas pelos tratamentos. 
Tabela 51 . Estoque de cobre nas folhas $\left(\mathrm{mg} \mathrm{planta}^{-1}\right)$ das quatro espécies, em função das doses crescentes de biossólido e adubação mineral

\begin{tabular}{lrrrr}
\hline TRATAMENTOS & AROEIRA & CABREUVA & PAU VIOLA & UNHA VACA \\
\hline TESTEMUNHA & $0.09 \mathrm{~b}$ & $0.08 \mathrm{a}$ & $0.07 \mathrm{a}$ & $0.06 \mathrm{a}$ \\
$1.25 \mathrm{~g} \mathrm{dm}-3$ & $0.10 \mathrm{~b}$ & $0.06 \mathrm{a}$ & $0.08 \mathrm{a}$ & $0.09 \mathrm{a}$ \\
$5.0 \mathrm{~g} \mathrm{dm}-3$ & $0.15 \mathrm{~b}$ & $0.09 \mathrm{a}$ & $0.11 \mathrm{a}$ & $0.11 \mathrm{a}$ \\
$20.0 \mathrm{~g} \mathrm{dm}-3$ & $0.21 \mathrm{a}$ & $0.10 \mathrm{a}$ & $0.18 \mathrm{a}$ & $0.14 \mathrm{a}$ \\
AD. MINERAL & $0.19 \mathrm{a}$ & $0.08 \mathrm{a}$ & $0.13 \mathrm{a}$ & $0.09 \mathrm{a}$ \\
\hline
\end{tabular}

Médias acompanhadas da mesma letra não diferem entre si pelo teste Tukey a $5 \%$.

O estoque de cobre aumentou em resposta ao tratamento com $20,00 \mathrm{~g}$ $\mathrm{dm}^{3}$ de biossólido nas raízes de aroeira, pau-de-viola e unha-de-vaca. A cabreúva não foi influenciada pelos tratamentos (Tabela 52).

Tabela 52. Estoque de cobre nas raízes ( $\mathrm{mg}$ planta ${ }^{-1}$ ) das quatro espécies, em função das doses crescentes de biossólido e adubação mineral

\begin{tabular}{lrrrr}
\hline TRATAMENTOS & AROEIRA & CABREUVA & PAU VIOLA & UNHA VACA \\
\hline TESTEMUNHA & $0.22 \mathrm{~b}$ & $0.09 \mathrm{a}$ & $0.37 \mathrm{c}$ & $0.27 \mathrm{~b}$ \\
$1.25 \mathrm{~g} \mathrm{dm}-3$ & $0.27 \mathrm{~b}$ & $0.08 \mathrm{a}$ & $0.51 \mathrm{c}$ & $0.40 \mathrm{~b}$ \\
$5.0 \mathrm{~g} \mathrm{dm}-3$ & $0.42 \mathrm{~b}$ & $0.13 \mathrm{a}$ & $0.87 \mathrm{bc}$ & $0.47 \mathrm{~b}$ \\
$20.0 \mathrm{~g} \mathrm{dm}-3$ & $2.09 \mathrm{a}$ & $0.27 \mathrm{a}$ & $2.50 \mathrm{a}$ & $1.22 \mathrm{a}$ \\
AD. MINERAL & $0.50 \mathrm{~b}$ & $0.18 \mathrm{a}$ & $0.74 \mathrm{c}$ & $0.60 \mathrm{~b}$ \\
\hline
\end{tabular}

Médias acompanhadas da mesma letra não diferem entre si pelo teste Tukey a $5 \%$.

O estoque de cobre no caule das quatro espécies apresentou tendência a aumento com as doses crescentes de biossólido (Figura 27) e tendência de ser maior em resposta ao tratamento com $20,00 \mathrm{~g} \mathrm{dm}^{3}$ em relação aos demais tratamentos. 


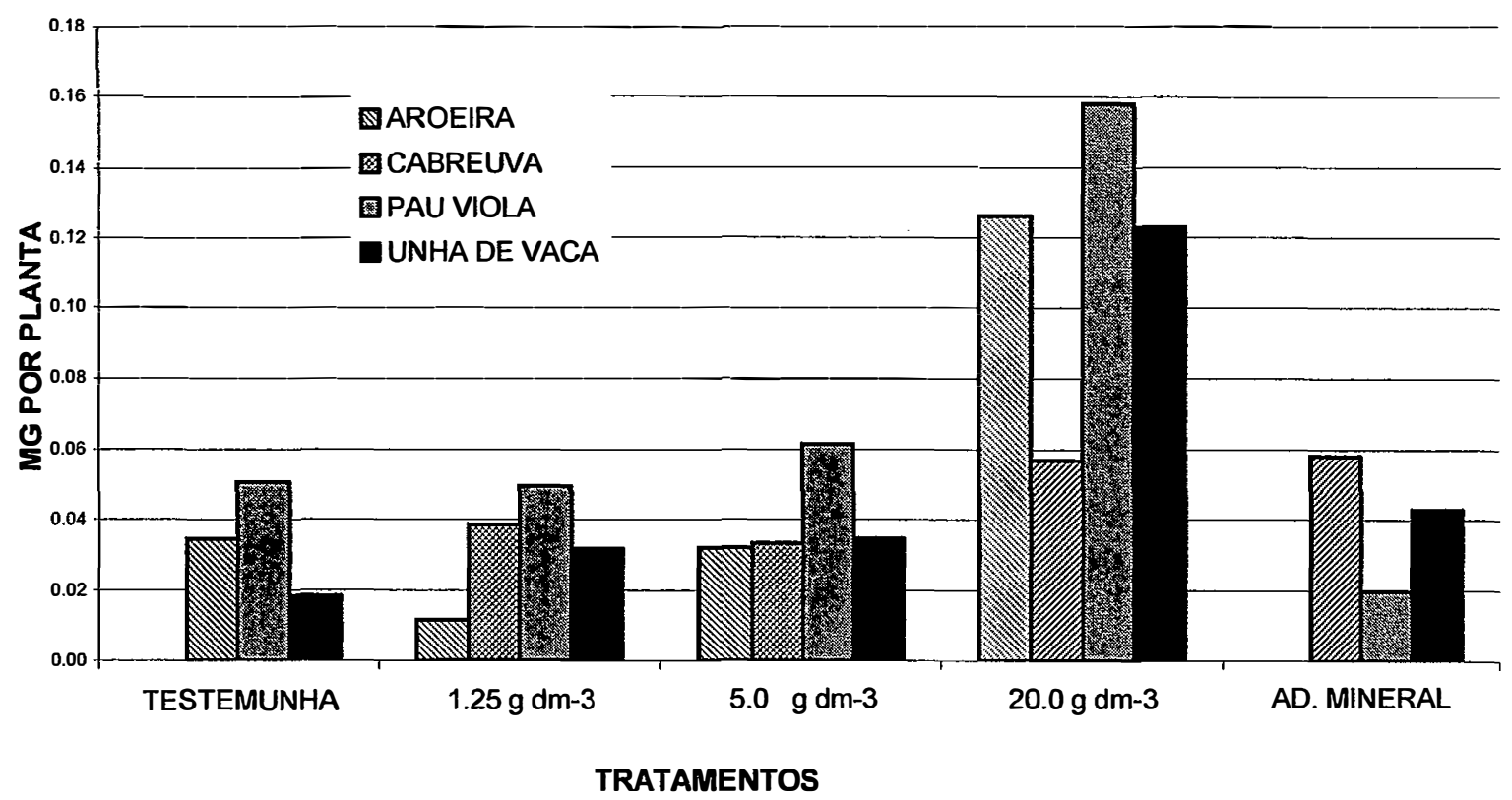

Figura 27- Estoque de cobre nos caules das quatro espécies (mg planta-1), em função das doses crescentes de biossólido e adubação mineral

A Figura 28 exibe uma tendência de aumento no estoque total de cobre nas quatro espécies, com o aumento da dosagem de biossólido, tendendo a ser maior para a dosagem de $20,00 \mathrm{~g} \mathrm{dm}^{3}$. 


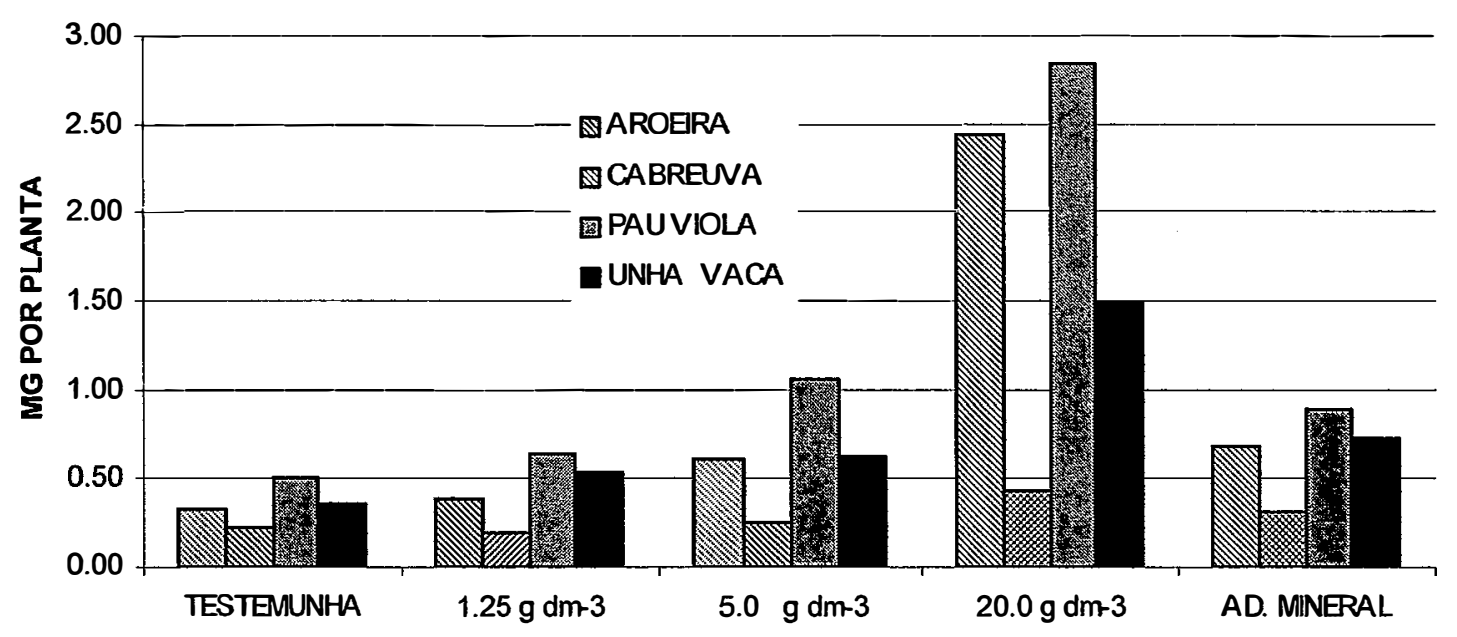

TRATAMENTOS

Figura 28 - Estoque total de cobre nas quatro espécies (mg planta ${ }^{-1}$ ), em função das doses crescentes de biossólido e adubação mineral

\subsubsection{Manganês}

A concentração de manganês aumentou nas folhas de cabreúva, pau-deviola e unha de vaca, e evidenciou uma tendência de aumentar na aroeira, em resposta às dosagens de $20 \mathrm{~g} \mathrm{dm}^{-3}$ de biossólido e adubação mineral (Tabela 53).

Kabata-Pendias et al. (1986) indicam deficiência de $\mathrm{Mn}$ em folhas de vegetais, para concentrações do elemento entre 15 e $20 \mathrm{mg} \mathrm{kg}^{-1}$, valores normais entre $20 \mathrm{mg} \mathrm{kg}^{-1}$ e $300 \mathrm{mg} \mathrm{kg}^{-1}$ e concentrações fitotóxicas entre 300 $\mathrm{mg} \mathrm{kg}^{-1}$ e $500 \mathrm{mg} \mathrm{kg}^{-1}$. Melo et al. ,citado por Marques et al. (2001), indica niveis fitotóxicos de $\mathrm{Mn}$ para concentrações do elemento em tecido vegetal entre $1500 \mathrm{mg} \mathrm{kg}^{-1}$ e $3000 \mathrm{mg} \mathrm{kg}^{-1}$. Neste trabalho são observados valores na faixa normal e fitotóxica para os primeiros autores $e$ abaixo dos níveis fitotóxicos para o segundo grupo de autores. Teixeira et al. (1998), estudando 
efeitos de metais pesados em plantas crescendo em área de mineração, encontraram concentrações de $\mathrm{Mn}$ em folhas de 5 espécies nativas entre $164 \mathrm{e}$ $454 \mathrm{mg} \mathrm{kg}^{-1}$, valores próximos aos encontrados nesta pesquisa. Resende (2005) encontrou valores em espécies nativas encontradas em sub bosque de eucalipto tratado com $20 \mathrm{t} \mathrm{ha}^{-1}$ de biossólido, variando entre $75,8 \mathrm{mg} \mathrm{kg}^{-1} \mathrm{e}$ $435 \mathrm{mg} \mathrm{kg}^{-1}$. Estas comparações com outras espécies se fazem necessárias por não existirem dados sobre concentrações deste elemento nas espécies utilizadas neste trabalho.

Tabela 53. Concentração de manganês nas folhas $\left(\mathrm{mg} \mathrm{kg}^{-1}\right)$ das quatro espécies, em função das doses crescentes de biossólido e adubação mineral

\begin{tabular}{lrrrr}
\hline TRATAMENTOS & AROEIRA & CABREUVA & PAU VIOLA & UNHA VACA \\
\hline TESTEMUNHA & $172.50 \mathrm{~b}$ & $45.25 \mathrm{~b}$ & $26.75 \mathrm{c}$ & $281.50 \mathrm{c}$ \\
$1.25 \mathrm{~g} \mathrm{dm}-3$ & $145.75 \mathrm{~b}$ & $53.75 \mathrm{~b}$ & $29.75 \mathrm{c}$ & $288.75 \mathrm{c}$ \\
$5.0 \mathrm{~g} \mathrm{dm}-3$ & $179.25 \mathrm{~b}$ & $42.50 \mathrm{~b}$ & $16.25 \mathrm{c}$ & $218.00 \mathrm{c}$ \\
$20.0 \mathrm{~g} \mathrm{dm}-3$ & $259.50 \mathrm{ab}$ & $127.20 \mathrm{a}$ & $126.25 \mathrm{~b}$ & $519.00 \mathrm{~b}$ \\
AD. MINERAL & $451.75 \mathrm{a}$ & $130.75 \mathrm{a}$ & $201.25 \mathrm{a}$ & $807.75 \mathrm{a}$ \\
\hline
\end{tabular}

Médias acompanhadas da mesma letra não diferem entre si pelo teste Tukey a $5 \%$.

A espécie que mais concentrou manganês nas folhas, em resposta a todos os tratamentos foi a unha-de-vaca, seguida pela aroeira. A cabreúva e o pau-de-viola acumularam menos manganês (Tabela 54).

Tabela 54. Concentração de manganês nas folhas $\left(\mathrm{mg} \mathrm{kg}^{-1}\right)$, comparando as quatro espécies, em função das doses crescentes de biossólido e adubação mineral

\begin{tabular}{lrrrr}
\hline ESPÉCIES & $1.25 \mathrm{~g} \mathrm{dm}^{-3}$ & $5.0 \mathrm{~g} \mathrm{dm}^{-3}$ & $20.0 \mathrm{~g} \mathrm{dm}^{-3}$ & AD. MINERAL \\
\hline AROEIRA & $145.75 \mathrm{~b}$ & $179.25 \mathrm{a}$ & $259.50 \mathrm{~b}$ & $451.75 \mathrm{~b}$ \\
CABREUVA & $53.75 \mathrm{c}$ & $42.50 \mathrm{~b}$ & $127.25 \mathrm{c}$ & $130.75 \mathrm{c}$ \\
PAU DE VIOLA & $29.75 \mathrm{c}$ & $16.25 \mathrm{~b}$ & $126.25 \mathrm{c}$ & $201.25 \mathrm{c}$ \\
UNHA DE VACA & $288.75 \mathrm{a}$ & $218.00 \mathrm{a}$ & $519.00 \mathrm{a}$ & $807.75 \mathrm{a}$ \\
\hline
\end{tabular}

Médias acompanhadas da mesma letra não diferem entre si pelo teste Tukey a $5 \%$.

Nas raízes, o pau-de-viola concentrou mais manganês em resposta aos tratamentos com $20,00 \mathrm{~g} \mathrm{dm}^{-3}$ de biossólido e adubação mineral. As demais 
espécies não apresentaram respostas significativas aos tratamentos(Tabela $55)$.

Tabela 55. Concentração de manganês nas raízes $\left(\mathrm{mg} \mathrm{kg}{ }^{-1}\right)$ das quatro espécies, em função das doses crescentes de biossólido e adubação mineral

\begin{tabular}{lrrrr}
\hline TRATAMENTOS & AROEIRA & CABREUVA & PAU VIOLA & UNHA VACA \\
\hline TESTEMUNHA & $107.26 \mathrm{a}$ & $157.54 \mathrm{a}$ & $109.75 \mathrm{~b}$ & $555.25 \mathrm{a}$ \\
$1.25 \mathrm{~g} \mathrm{dm}-3$ & $154.20 \mathrm{a}$ & $144.96 \mathrm{a}$ & $141.75 \mathrm{~b}$ & $296.50 \mathrm{a}$ \\
$5.0 \mathrm{~g} \mathrm{dm}-3$ & $84.38 \mathrm{a}$ & $164.64 \mathrm{a}$ & $109.75 \mathrm{~b}$ & $333.50 \mathrm{a}$ \\
$20.0 \mathrm{~g} \mathrm{dm}-3$ & $115.02 \mathrm{a}$ & $170.10 \mathrm{a}$ & $265.75 \mathrm{a}$ & $316.50 \mathrm{a}$ \\
AD. MINERAL & $138.09 \mathrm{a}$ & $176.63 \mathrm{a}$ & $234.50 \mathrm{a}$ & $256,00 \mathrm{a}$ \\
\hline
\end{tabular}

Médias acompanhadas da mesma letra não diferem entre si pelo teste Tukey a 5\%.

A unha-de-vaca foi a espécie que mais concentrou manganês em suas raízes em resposta ao tratamento com $20,00 \mathrm{~g} \mathrm{dm}^{-3}$ de biossólido. $O$ pau-deviola apresentou tendência de acúmulo igual à unha-de-vaca e maior que as outras duas espécies (Tabela 56).

Tabela 56 . Concentração de manganês nas raízes $\left(\mathrm{mg} \mathrm{kg}^{-1}\right)$ comparando as quatro espécies, em função das doses crescentes de biossólido e adubação mineral

\begin{tabular}{|c|c|c|c|c|}
\hline ESPÉCIES & $1.25 \mathrm{~g} \mathrm{dm}^{-3}$ & $g \mathrm{dm}^{-3}$ & $20.0 \mathrm{~g} \mathrm{dm}^{-3}$ & AD. MINERAL \\
\hline AROEIRA & $154.30 \mathrm{a}$ & $84.38 a$ & $123.25 b$ & $138.09 a$ \\
\hline CABREUVA & $144.96 a$ & $164.64 a$ & $178.50 \mathrm{~b}$ & $176.63 a$ \\
\hline PAU DE VIOLA & $139.97 a$ & 106.30a & $265.75 a b$ & $230.37 a$ \\
\hline UNHA DE VACA & $263.02 a$ & $199.31 \mathrm{a}$ & $316.50 \mathrm{a}$ & $249.03 a$ \\
\hline
\end{tabular}

Médias acompanhadas da mesma letra não diferem entre si pelo teste Tukey a $5 \%$.

A relação de concentração entre folhas e raízes, exibida pela (Figura 29), mostra uma tendência para o aumento das concentrações de Mn nas folhas, na medida em que se aumenta a dose de biossólido. A cabreúva e o pau-de-viola tenderam a concentrar mais $M n$ em suas raízes. $A$ aroeira e a unha-de-vaca tenderam a acumular mais em suas folhas. 


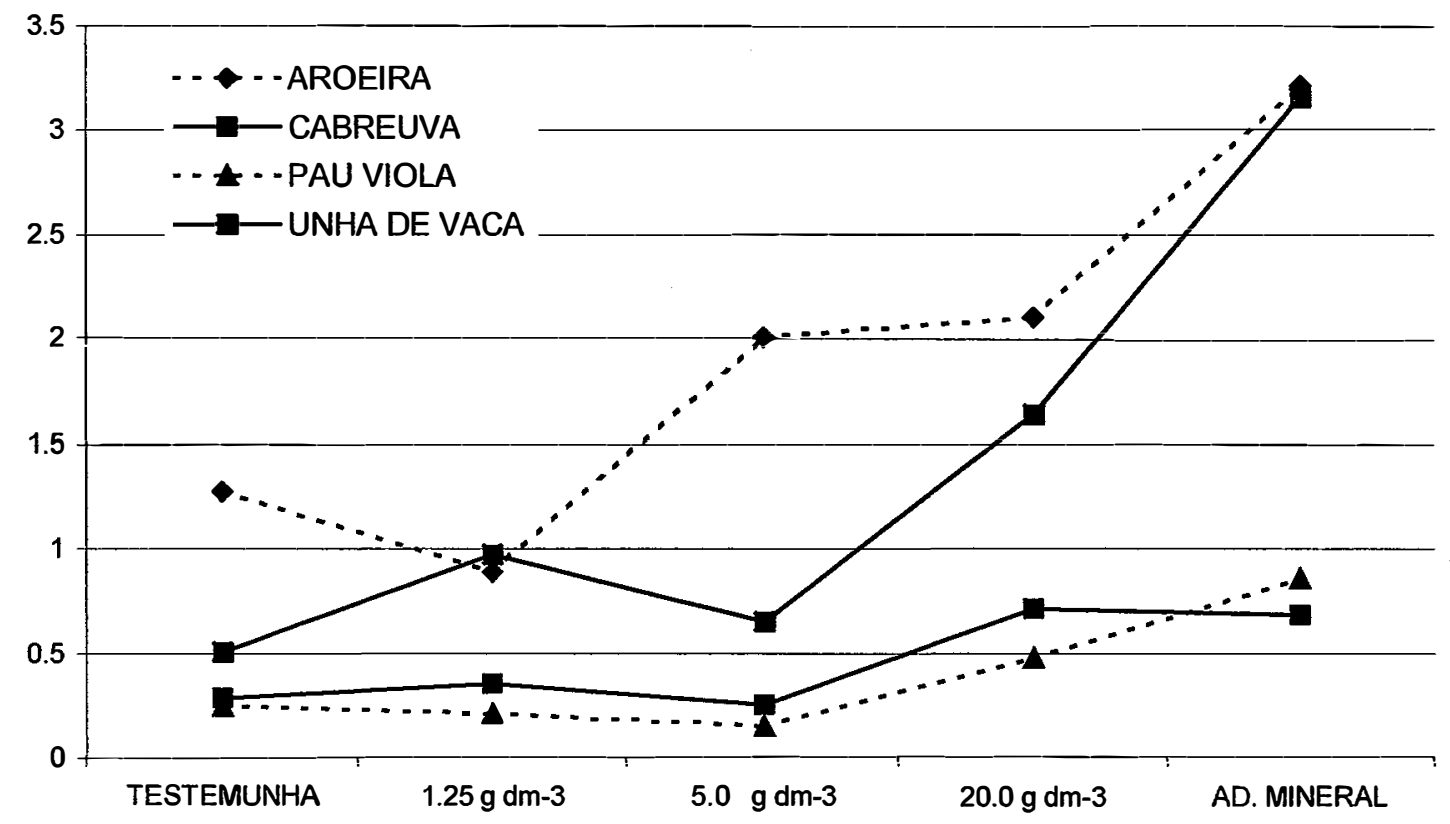

TRATAMENTOS

Figura 29 - Relação das concentrações de Manganês entre folhas e raízes, em função das doses crescentes de biossólido e adubação mineral

O estoque de manganês nas folhas (Tabela 57) foi significativamente maior na aroeira, pau-de-viola e unha-de-vaca, apresentando tendência a ser maior na cabreúva, para o tratamento com $20,00 \mathrm{~g} \mathrm{dm}^{-3}$ de biossólido. Também foi significativamente maior para as três espécies em resposta à adubação mineral, sendo não significativo para a cabreúva. 
Tabela 57 . Estoque de manganês nas folhas $\left(\mathrm{mg} \mathrm{planta}^{-1}\right)$ das quatro espécies, em função das doses crescentes de biossólido e adubação mineral

\begin{tabular}{lrrrr}
\hline TRATAMENTOS & AROEIRA & CABREUVA & PAU VIOLA & UNHA DE VACA \\
\hline TESTEMUNHA & $2.28 \mathrm{c}$ & $0.37 \mathrm{~b}$ & $0.26 \mathrm{c}$ & $2.38 \mathrm{c}$ \\
$1.25 \mathrm{~g} \mathrm{dm}-3$ & $2.16 \mathrm{c}$ & $0.43 \mathrm{~b}$ & $0.28 \mathrm{c}$ & $2.63 \mathrm{c}$ \\
$5.0 \mathrm{~g} \mathrm{dm}-3$ & $3.37 \mathrm{c}$ & $0.37 \mathrm{~b}$ & $0.20 \mathrm{c}$ & $2.41 \mathrm{c}$ \\
$20.0 \mathrm{~g} \mathrm{dm}-3$ & $10.37 \mathrm{~b}$ & $1.45 \mathrm{ab}$ & $2.82 \mathrm{~b}$ & $7.80 \mathrm{~b}$ \\
AD. MINERAL & $19.21 \mathrm{a}$ & $1.09 \mathrm{~b}$ & $4.97 \mathrm{a}$ & $13.07 \mathrm{a}$ \\
\hline
\end{tabular}

Médias acompanhadas da mesma letra não diferem entre si pelo teste Tukey a $5 \%$.

A aroeira e o pau-de-viola acumularam mais manganês em suas raízes em resposta à adubação mineral (Tabela 58) . O pau-de-viola estocou mais manganês. A aroeira apresentou tendência de maior acúmulo em resposta à dosagem de $20 \mathrm{~g} \mathrm{dm}^{-3}$ de biossólido em relação à testemunha.

Tabela 58 . Estoque de manganês nas raizes $\left(\mathrm{mg} \mathrm{planta}^{-1}\right)$ das quatro espécies, em função das doses crescentes de biossólido e adubação mineral

\begin{tabular}{lrrrr}
\hline TRATAMENTOS & AROEIRA & CABREUVA & PAU VIOLA & UNHA VACA \\
\hline TESTEMUNHA & $1.78 \mathrm{~b}$ & $1.15 \mathrm{a}$ & $1.63 \mathrm{~b}$ & $6.82 \mathrm{a}$ \\
$1.25 \mathrm{~g} \mathrm{dm}-3$ & $2.57 \mathrm{~b}$ & $1.08 \mathrm{a}$ & $2.22 \mathrm{~b}$ & $4.06 \mathrm{a}$ \\
$5.0 \mathrm{~g} \mathrm{dm}-3$ & $1.55 \mathrm{~b}$ & $1.19 \mathrm{a}$ & $2.71 \mathrm{~b}$ & $5.32 \mathrm{a}$ \\
$20.0 \mathrm{~g} \mathrm{dm}-3$ & $3.27 \mathrm{ab}$ & $1.41 \mathrm{a}$ & $9.58 \mathrm{a}$ & $5.81 \mathrm{a}$ \\
AD. MINERAL & $4.56 \mathrm{a}$ & $1.44 \mathrm{a}$ & $8.99 \mathrm{a}$ & $5.79 \mathrm{a}$ \\
\hline
\end{tabular}

Médias acompanhadas da mesma letra não diferem entre si pelo teste Tukey a $5 \%$.

O estoque de manganês no caule das quatro espécies apresentou tendência a ser menor do que nos demais compartimentos das plantas (Figura 30). As respostas aos tratamentos com $20 \mathrm{~g} \mathrm{dm}^{-3}$ e adubação mineral tenderam a ser maiores do que para os demais tratamentos. 


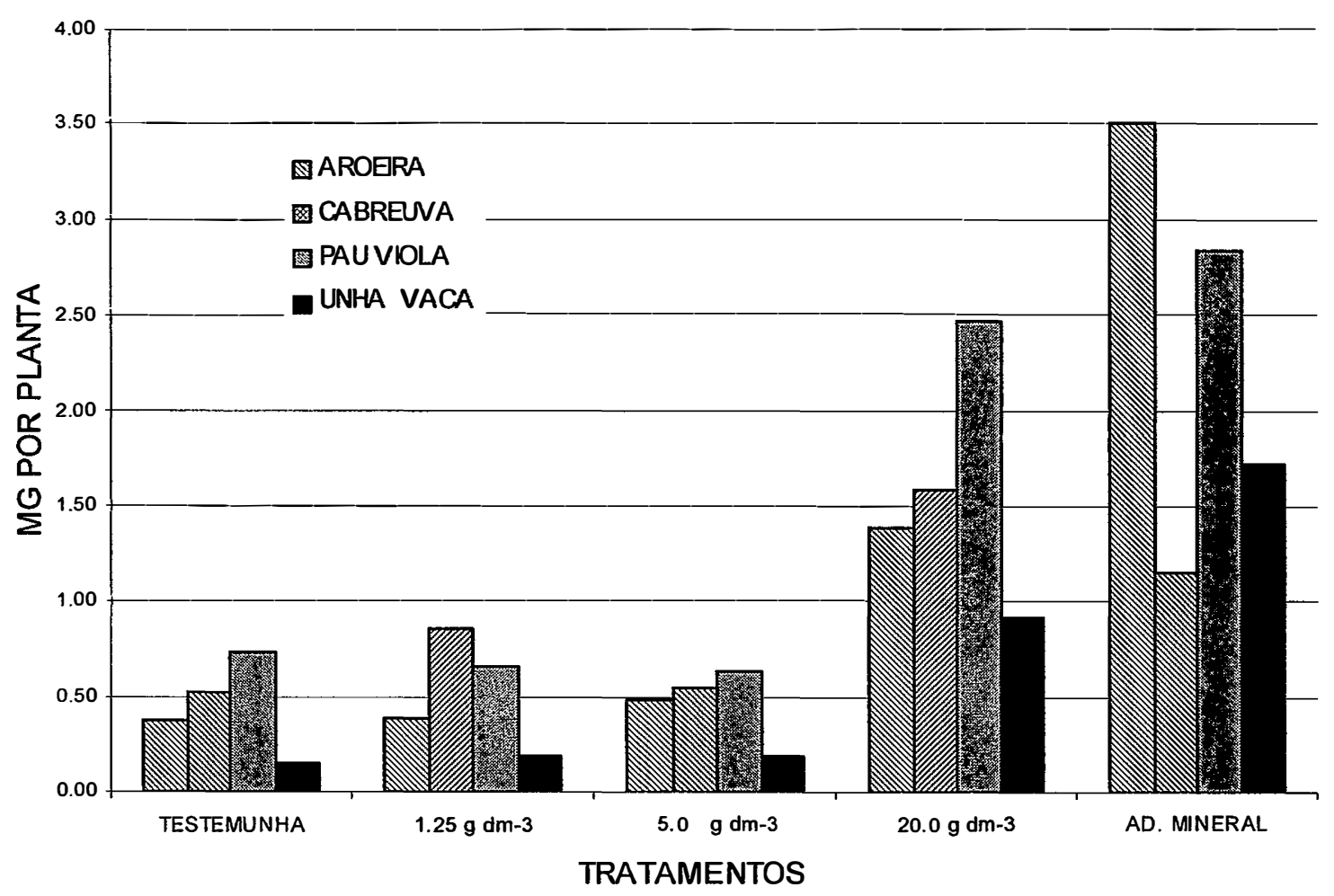

Figura 30 - Estoque de manganês nos caules das quatro espécies (mg planta ${ }^{-1}$ ), em função das doses crescentes de biossólido e adubação mineral

O estoque total de manganês tendeu a ser maior em resposta aos

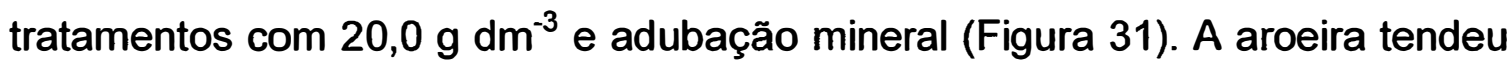
a estocar mais manganês que todas as outras espécies em todos os tratamentos e a cabreúva tendeu a estocar menos para todos os tratamentos. 


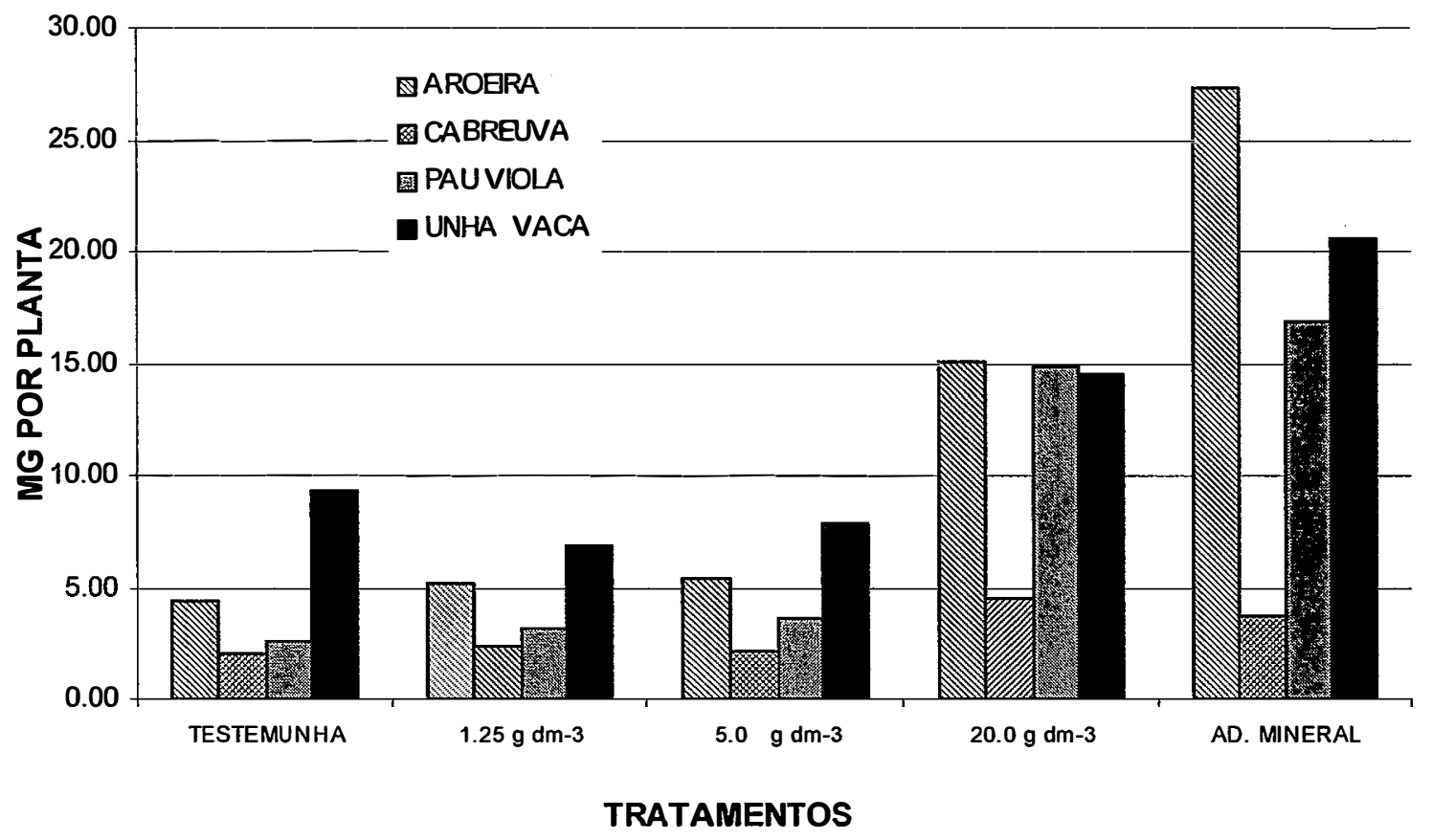

Figura 31 - Estoque total de manganês nas quatro espécies (mg planta-1), em função das doses crescentes de biossólido e adubação mineral

\subsubsection{Zinco}

As concentrações de zinco nasfolhas das quatro espécies não foram afetadas pelos tratamentos (Tabela 59), com exceção da unha-de-vaca em resposta à adubação mineral, que foi maior que a testemunha. Entre as espécies não houve diferenças estatisticamente significativas.

As concentrações de $\mathrm{Zn}$ em folhas de vegetais são consideradas deficientes entre $10 \mathrm{mg} \mathrm{kg}^{-1}$ e $20 \mathrm{mg} \mathrm{kg}^{-1}$, normais entre $27 \mathrm{mg} \mathrm{kg}^{-1}$ e 150 $\mathrm{mg} \mathrm{kg}^{-1}$ e fitotóxicas entre $100 \mathrm{mg} \mathrm{kg}^{-1}$ e $400 \mathrm{mg} \mathrm{kg}^{-1}$, segundo KabataPendias et al. (1986). Os níveis encontrados nas folhas são considerados normais. 
Tabela 59. Concentração de zinco nas folhas $\left(\mathrm{mg} \mathrm{kg}^{-1}\right)$ das quatro espécies, em função das doses crescentes de biossólido e adubação mineral

\begin{tabular}{lrrrr}
\hline TRATAMENTOS & AROEIRA & CABREUVA & PAU VIOLA & UNHA VACA \\
\hline TESTEMUNHA & $29.78 \mathrm{a}$ & $27.87 \mathrm{a}$ & $23.58 \mathrm{a}$ & $31.75 \mathrm{~b}$ \\
$1.25 \mathrm{~g} \mathrm{dm}-3$ & $30.05 \mathrm{a}$ & $26.35 \mathrm{a}$ & $24.34 \mathrm{a}$ & $30.87 \mathrm{~b}$ \\
$5.0 \mathrm{~g} \mathrm{dm}-3$ & $25.37 \mathrm{a}$ & $26.92 \mathrm{a}$ & $22.31 \mathrm{a}$ & $24.87 \mathrm{~b}$ \\
$20.0 \mathrm{~g} \mathrm{dm}-3$ & $25.35 \mathrm{a}$ & $28.74 \mathrm{a}$ & $24.67 \mathrm{a}$ & $30.00 \mathrm{~b}$ \\
AD. MINERAL & $31.37 \mathrm{a}$ & $30.75 \mathrm{a}$ & $30.24 \mathrm{a}$ & $45.00 \mathrm{a}$ \\
\hline
\end{tabular}

Médias acompanhadas da mesma letra não diferem entre si pelo teste Tukey a $5 \%$.

Observa-se, pela Tabela 60, concentrações significativamente maiores nas raízes para as quatro espécies, em resposta ao tratamento com $20,00 \mathrm{~g}$ $\mathrm{dm}^{-3}$ de biossólido.

Tabela 60. Concentração de zinco nas raízes $\left(\mathrm{mg} \mathrm{kg}^{-1}\right)$ das quatro espécies, em função das doses crescentes de biossólido e adubação mineral

\begin{tabular}{lrrrr}
\hline TRATAMENTOS & AROEIRA & CABREUVA & PAU VIOLA & UNHA VACA \\
\hline TESTEMUNHA & $5.15 \mathrm{~b}$ & $2.50 \mathrm{~b}$ & $6.67 \mathrm{c}$ & $9.77 \mathrm{~b}$ \\
$1.25 \mathrm{~g} \mathrm{dm}-3$ & $7.90 \mathrm{~b}$ & $2.37 \mathrm{~b}$ & $10.25 \mathrm{~b}$ & $9.95 \mathrm{~b}$ \\
$5.0 \mathrm{~g} \mathrm{dm}-3$ & $7.92 \mathrm{~b}$ & $3.45 \mathrm{~b}$ & $9.30 \mathrm{bc}$ & $10.62 \mathrm{~b}$ \\
$20.0 \mathrm{~g} \mathrm{dm}-3$ & $25.32 \mathrm{a}$ & $5.17 \mathrm{a}$ & $14.22 \mathrm{a}$ & $18.62 \mathrm{a}$ \\
AD. MINERAL & $6.17 \mathrm{~b}$ & $4.40 \mathrm{a}$ & $6.95 \mathrm{c}$ & $9.22 \mathrm{~b}$ \\
\hline
\end{tabular}

Médias acompanhadas da mesma letra não diferem entre si pelo teste Tukey a $5 \%$.

A dose de $5,00 \mathrm{~g} \mathrm{dm}^{-3}$ de biossólido aumentou o estoque de zinco nas folhas de aroeira. $O$ tratamento com $20,00 \mathrm{~g} \mathrm{dm}^{-3}$ de biossólido aumentou significativamente o estoque de zinco nas folhas de aroeira, pau-de-viola e promoveu uma tendência de aumento na unha-de-vaca (Tabela 61). A adubação mineral promoveu maiores estoques nas folhas de pau-de-viola e unha-de-vaca com relação à testemunha. Isto demonstra ser o biossólido uma boa fonte deste elemento às plantas. 
Tabela 61 . Estoque de zinco nas folhas (mg planta-1) nas quatro espécies, em função das doses crescentes de biossólido e adubação mineral

\begin{tabular}{lrrrr}
\hline TRATAMENTOS & AROEIRA & CABREUVA & PAU VIOLA & UNHA DE VACA \\
\hline TESTEMUNHA & $4.09 \mathrm{~b}$ & $2.31 \mathrm{a}$ & $2.34 \mathrm{~b}$ & $2.68 \mathrm{~b}$ \\
$1.25 \mathrm{~g} \mathrm{dm}^{-3}$ & $4.56 \mathrm{~b}$ & $2.14 \mathrm{a}$ & $2.37 \mathrm{~b}$ & $2.84 \mathrm{~b}$ \\
$5.0 \mathrm{~g} \mathrm{dm}^{-3}$ & $4.86 \mathrm{c}$ & $2.38 \mathrm{a}$ & $2.77 \mathrm{~b}$ & $2.75 \mathrm{~b}$ \\
$20.0 \mathrm{~g} \mathrm{dm}^{-3}$ & $10.30 \mathrm{a}$ & $3.22 \mathrm{a}$ & $5.59 \mathrm{a}$ & $4.46 \mathrm{ab}$ \\
AD. MINERAL & $13.48 \mathrm{~b}$ & $2.67 \mathrm{a}$ & $7.40 \mathrm{a}$ & $7.26 \mathrm{a}$ \\
\hline
\end{tabular}

Médias acompanhadas da mesma letra não diferem entre si pelo teste Tukey a $5 \%$.

O estoque de zinco nas raízes (Tabela 62) foi aumentado significativamente nas quatro espécies em resposta ao tratamento com 20,00 g $\mathrm{dm}^{-3}$ de biossólido. A adubação mineral aumentou o estoque de zinco nas raízes de pau-de-viola.

Tabela 62 .Estoque de zinco nas raízes $\left(\mathrm{mg} \mathrm{planta}^{-1}\right)$ das quatro espécies , em função das doses crescentes de biossólido e adubação mineral

\begin{tabular}{lrrrr}
\hline TRATAMENTOS & AROEIRA & CABREUVA & PAU VIOLA & UNHA DE VACA \\
\hline TESTEMUNHA & $0.70 \mathrm{~b}$ & $0.18 \mathrm{~b}$ & $1.013 \mathrm{c}$ & $1.19 \mathrm{~b}$ \\
$1.25 \mathrm{~g} \mathrm{dm}-3$ & $1.24 \mathrm{~b}$ & $0.17 \mathrm{~b}$ & $1.62 \mathrm{bc}$ & $1.37 \mathrm{~b}$ \\
$5.0 \mathrm{~g} \mathrm{dm}-3$ & $1.37 \mathrm{~b}$ & $0.24 \mathrm{~b}$ & $2.27 \mathrm{~b}$ & $1.81 \mathrm{~b}$ \\
$20.0 \mathrm{~g} \mathrm{dm}-3$ & $6.75 \mathrm{a}$ & $0.43 \mathrm{a}$ & $5.19 \mathrm{ab}$ & $3.40 \mathrm{a}$ \\
AD. MINERAL & $2,00 \mathrm{~b}$ & $0.33 \mathrm{~b}$ & $2.66 \mathrm{~b}$ & $1.97 \mathrm{~b}$ \\
\hline
\end{tabular}

Médias acompanhadas da mesma letra não diferem entre si pelo teste Tukey a $5 \%$.

A aroeira estocou mais zinco em suas folhas do que as outras três espécies, em resposta a todos os tratamentos. A cabreúva, pau-de-viola e unha-de-vaca não acusaram diferenças significativas de estoque de zinco entre si, para os tratamentos com biossólido, mas a cabreúva estocou menos que as outras duas espécies em resposta à adubação mineral (Tabela 63). 
Tabela 63 . Estoque de zinco nas folhas $\left(\mathrm{mg} \mathrm{planta}^{-1}\right)$, comparando as quatro espécies, em função das doses crescentes de biossólido e adubação mineral

\begin{tabular}{lrrrr}
\hline ESPÉCIES & $1.25 \mathrm{~g} \mathrm{dm}^{-3}$ & $5.0 \mathrm{~g} \mathrm{dm}^{-3}$ & $20.0 \mathrm{~g} \mathrm{dm}^{-3}$ & AD. MINERAL \\
\hline AROEIRA & $4.56 \mathrm{a}$ & $4.86 \mathrm{a}$ & $10.30 \mathrm{a}$ & $13.48 \mathrm{a}$ \\
CABREUVA & $2.14 \mathrm{~b}$ & $2.38 \mathrm{~b}$ & $3.22 \mathrm{~b}$ & $2.69 \mathrm{c}$ \\
PAU DE VIOLA & $2.37 \mathrm{~b}$ & $2.77 \mathrm{~b}$ & $5.58 \mathrm{~b}$ & $7.40 \mathrm{~b}$ \\
UNHA DE VACA & $2.83 \mathrm{~b}$ & $2.75 \mathrm{~b}$ & $4.46 \mathrm{~b}$ & $7.26 \mathrm{~b}$ \\
\hline
\end{tabular}

Médias acompanhadas da mesma letra não diferem entre si pelo teste Tukey a 5\%.

A cabreúva estocou menos zinco nas suas raízes do que as outras três espécies em resposta aos tratamentos com biossólido e adubação mineral (Tabela 64). As outras três espécies não apresentaram diferenças significativas entre si em resposta aos mesmos tratamentos. A adubação mineral promoveu maior estoque em pau-de-viola e menor estoque em cabreúva que nas outras duas espécies. A aroeira e unha-de-vaca estocaram quantidades iguais.

Tabela 64 .Estoque de zinco nas raízes $\left(\mathrm{mg} \mathrm{planta}^{-1}\right)$, comparando as quatro espécies, em função das doses crescentes de biossólido e adubação mineral

\begin{tabular}{lrrrr}
\hline ESPÉCIES & $1.25 \mathrm{~g} \mathrm{dm}^{-3}$ & $5.0 \mathrm{~g} \mathrm{dm}^{-3}$ & $20.0 \mathrm{~g} \mathrm{dm}^{-3}$ & AD. MINERAL \\
\hline AROEIRA & $1.24 \mathrm{a}$ & $1.37 \mathrm{a}$ & $6.75 \mathrm{a}$ & $1.99 \mathrm{~b}$ \\
CABREUVA & $0.17 \mathrm{~b}$ & $0.24 \mathrm{~b}$ & $0.43 \mathrm{~b}$ & $0.33 \mathrm{c}$ \\
PAU DE VIOLA & $1.62 \mathrm{a}$ & $2.27 \mathrm{a}$ & $5.19 \mathrm{a}$ & $2.66 \mathrm{a}$ \\
UNHA DE VACA & $1.37 \mathrm{a}$ & $1.81 \mathrm{a}$ & $3.40 \mathrm{a}$ & $1.97 \mathrm{~b}$ \\
\hline
\end{tabular}

Médias acompanhadas da mesma letra não diferem entre si pelo teste Tukey a $5 \%$.

Analisando o estoque de zinco entre folhas e raízes pela Figura 32, percebe-se uma tendência de aumento do estoque em raízes com o aumento das doses de biossólido em todas as espécies, em detrimento das folhas, havendo uma tendência inversa em resposta à adubação mineral. A cabreúva exibe uma tendência a acumular mais zinco nas folhas e as outras três espécies na raiz. 


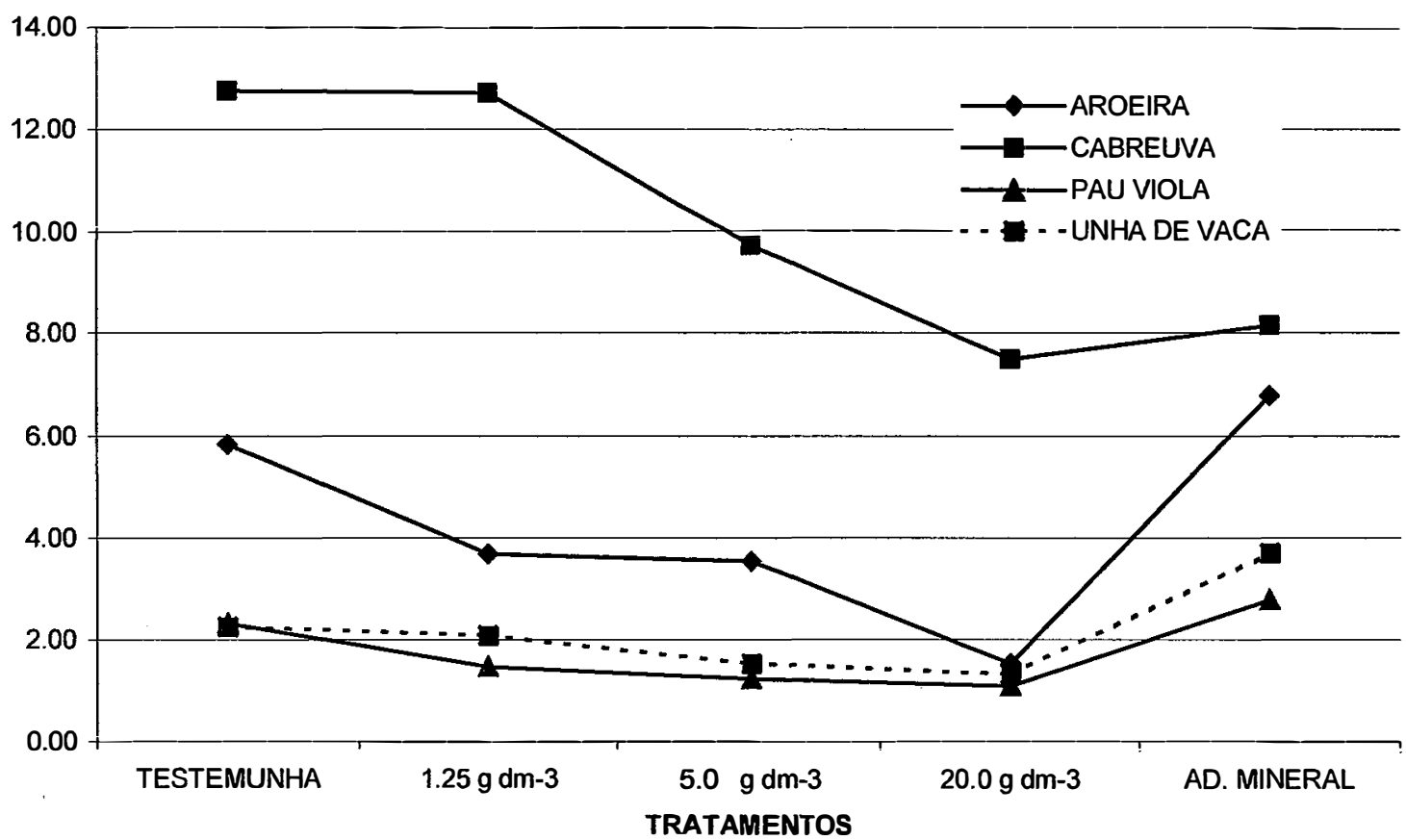

Figura 32 - Relação de estoque de zinco entre folhas e raízes nas quatro espécies, em função das doses crescentes de biossólido e adubação mineral

O estoque de zinco nos caules das quatro espécies, exibido pela Figura 33, mostra tendência de aumento em resposta ao aumento das doses de biossólido, com tendência a ser maior nas espécies de início de sucessão e menor nas de final de sucessão. 


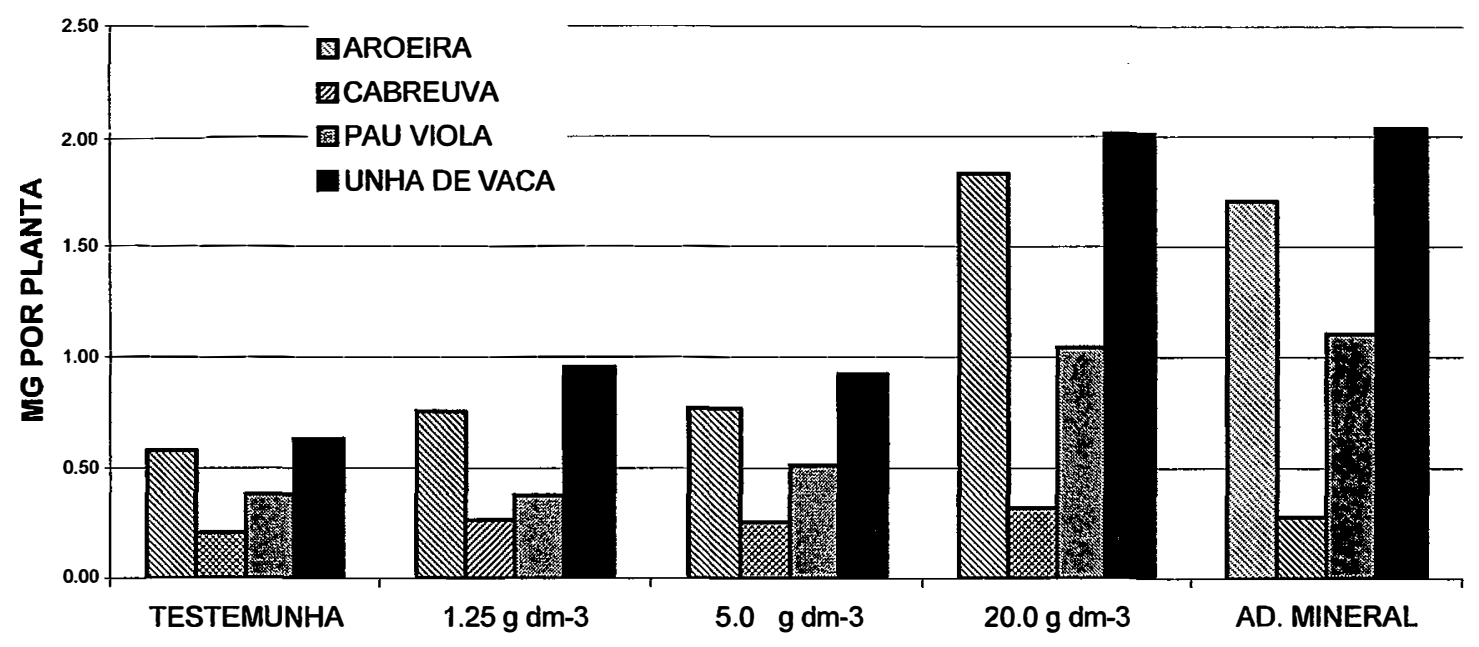

TRATAMENTOS

Figura 33 - Estoque de zinco nos caules nas quatro espécies ( $m g$ planta ${ }^{-1}$ ), em função das doses crescentes de biossólido e adubação mineral

O estoque total de zinco nas quatro espécies, exibido pela Figura 34 , apresenta tendência para valores maiores em resposta aos tratamentos de $20,00 \mathrm{~g} \mathrm{dm}^{-3}$ de biossólido e adubação mineral. Também exibe tendência para maiores estoques nas espécies de início de sucessão em resposta a todos os tratamentos. Os estoques tendem a ser iguais em resposta aos tratamentos com $20,00 \mathrm{~g} \mathrm{dm}^{-3}$ de biossólido e adubação mineral. 


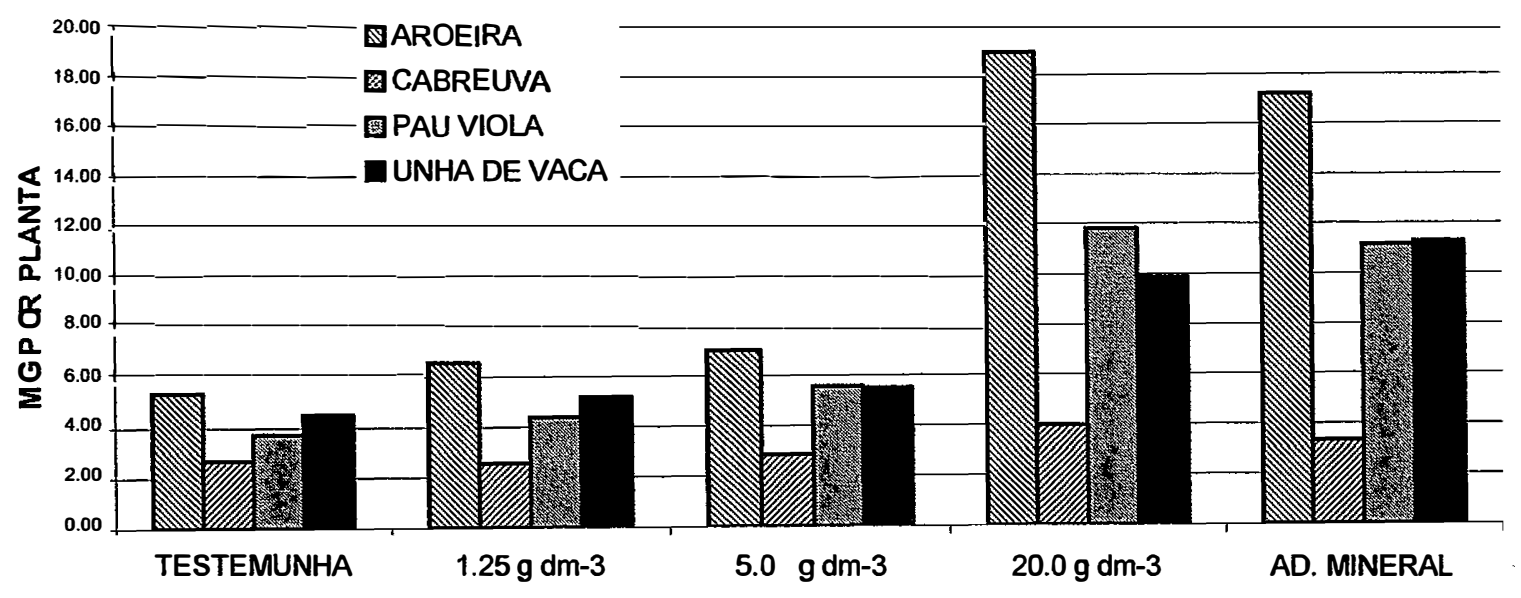

TRATAMENTOS

Figura 34 - Estoque total de zinco nas quatro espécies ( $m g$ planta ${ }^{-1}$ ), em função das doses crescentes de biossólido e adubação mineral

\subsubsection{Ferro}

As concentrações de ferro nas folhas e raizes não apresentaram diferenças estatisticamente significativas em resposta aos tratamentos, por apresentarem variâncias desiguais $(P<0,05)$. Houve uma tendência de redução na concentração com o aumento das doses, mas permanecendo entre $152 \mathrm{mg} \mathrm{kg}^{-1}$ a $344 \mathrm{mg} \mathrm{kg}^{-1}$ para a dose de $20,00 \mathrm{~g} \mathrm{dm}^{-3}$, considerada fitotóxica por Melo et al. citado por Marques et al. (2001).

Os estoques de ferro em folhas foram maiores em resposta à adubação mineral para todas as espécies (Tabela 65). $O$ tratamento com $20,00 \mathrm{~g} \mathrm{dm}^{-3} \mathrm{de}$ biossólido promoveu uma tendência de aumento na aroeira e unha-de-vaca. Nas raízes e caules, os tratamentos não influenciaram os estoques de ferro em nenhuma espécie, devido a variâncias desiguais $(P<0,05)$. 
Tabela 65 .Estoque de ferro nas folhas $\left(\mathrm{mg} \mathrm{planta}^{-1}\right)$ das quatro espécies, em função das doses crescentes de biossólido e adubação mineral

\begin{tabular}{lrrrr}
\hline TRATAMENTOS & AROEIRA & CABREUVA & PAU VIOLA & UNHA VACA \\
\hline TESTEMUNHA & $3.00 \mathrm{~b}$ & $2.65 \mathrm{a}$ & $2.05 \mathrm{~b}$ & $2.22 \mathrm{~b}$ \\
$1.25 \mathrm{~g} \mathrm{dm}-3$ & $2.74 \mathrm{~b}$ & $2.86 \mathrm{a}$ & $2.03 \mathrm{~b}$ & $2.49 \mathrm{~b}$ \\
$5.0 \mathrm{~g} \mathrm{dm}-3$ & $2.65 \mathrm{~b}$ & $1.91 \mathrm{a}$ & $1.63 \mathrm{~b}$ & $2.55 \mathrm{~b}$ \\
$20.0 \mathrm{~g} \mathrm{dm}-3$ & $6.13 \mathrm{ab}$ & $3.60 \mathrm{a}$ & $3.38 \mathrm{~b}$ & $3.27 \mathrm{ab}$ \\
AD. MINERAL & $12.87 \mathrm{a}$ & $3.95 \mathrm{a}$ & $6.45 \mathrm{a}$ & $6.21 \mathrm{a}$ \\
\hline
\end{tabular}

Médias acompanhadas da mesma letra não diferem entre si pelo teste Tukey a $5 \%$.

Os estoques totais de ferro podem ser observados pela Figura 35, exibindo valores maiores para as espécies de início de sucessão, como aroeira, pau-de-viola e unha de vaca e menor para cabreúva. Não existe um padrão definido de resposta entre aumento de doses de biossólido e estoque de ferro.

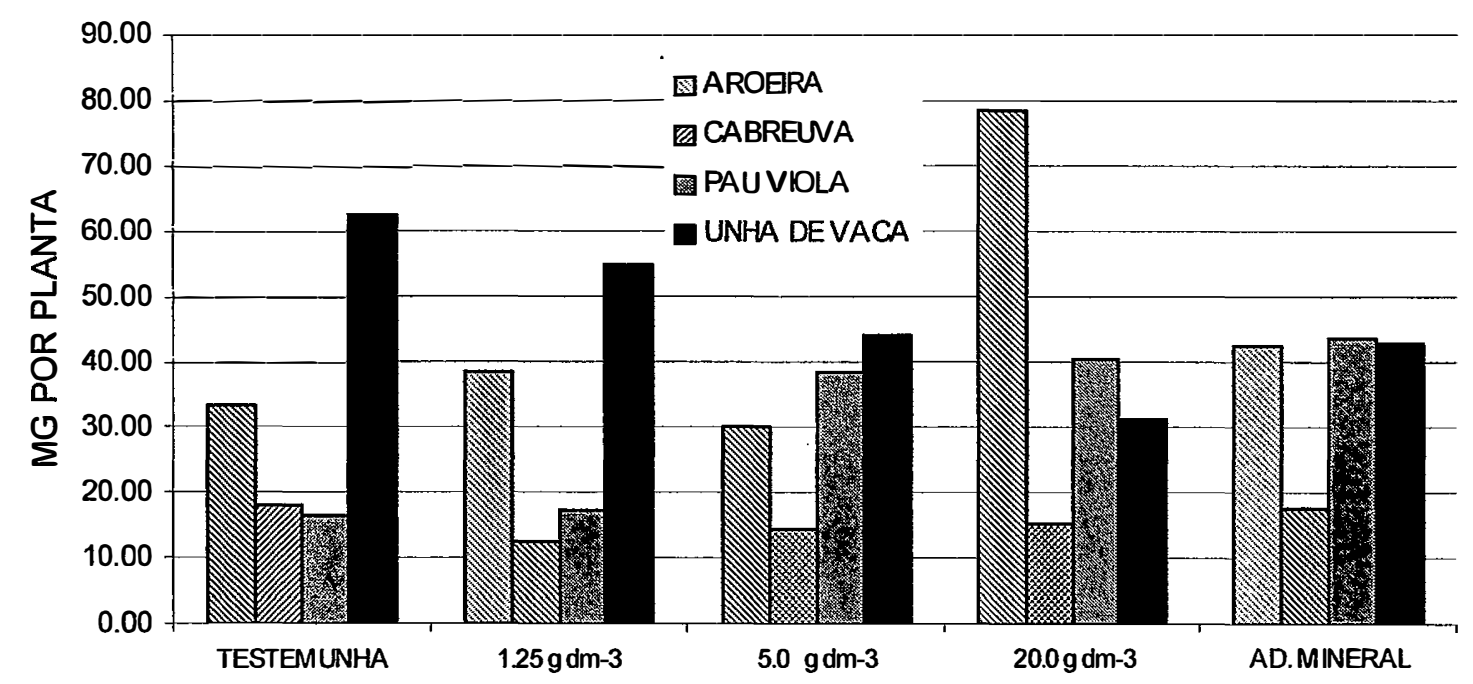

TRATAMENTOS

Figura 35 - Estoque total de ferro nas quatro espécies ( $m g$ planta ${ }^{-1}$ ), em função das doses crescentes de biossólido e adubação mineral 


\subsection{Metais pesados}

Uma questão fundamental na discussão do uso de biossólido na produção agrícola e florestal é a dinâmica de metais pesados, sua concentração, distribuição e acúmulo nos compartimentos das plantas e do ecossistema, bem como a análise de riscos.

O biossólido utilizado nesse trabalho, oriundo da ETE Barueri, possui todos os teores de metais pesados abaixo do estabelecido pela CETESB (1999).

Segundo a teoria do platô, comentada por Marques et al.(2001), a capacidade de adsorção do biossólido é que define a disponibilidade do metal no solo. Quando se aplicam sucessivas doses de biossólido, os metais pesados acumulam nas plantas até atingirem determinados valores e se estabilizam (platô).

Os elementos podem ser considerados no desenvolvimento das plantas, pelo seu papel no metabolismo (essencialidade) e sua concentração (deficiência ou excesso), segundo Kabata-Pendias \& Pendias (1986). As concentrações médias de metais pesados presentes nas amostras colhidas de folhas e raízes das quatro espécies estudadas podem ser observadas através das Figuras 36 e 37.

Nas raizes, observa-se maior concentração de metais pesados na aroeira e menor na cabreúva, respectivamente espécies de início e de final de sucessão vegetal. Também se observa concentração diferenciada para cada metal pesado, indicando seletividade na absorção dos elementos. O níquel e o cromo foram os metais pesados absorvidos em maiores quantidades pelas raízes da aroeira, sendo o chumbo o metal pesado absorvido em maior quantidade pela unha-de-vaca. Genericamente, segundo Soares (1999) observa-se que as raízes apresentam maiores concentrações de metais que as folhas, por serem as primeiras partes das folhas a entrarem em contato com eles no solo. 


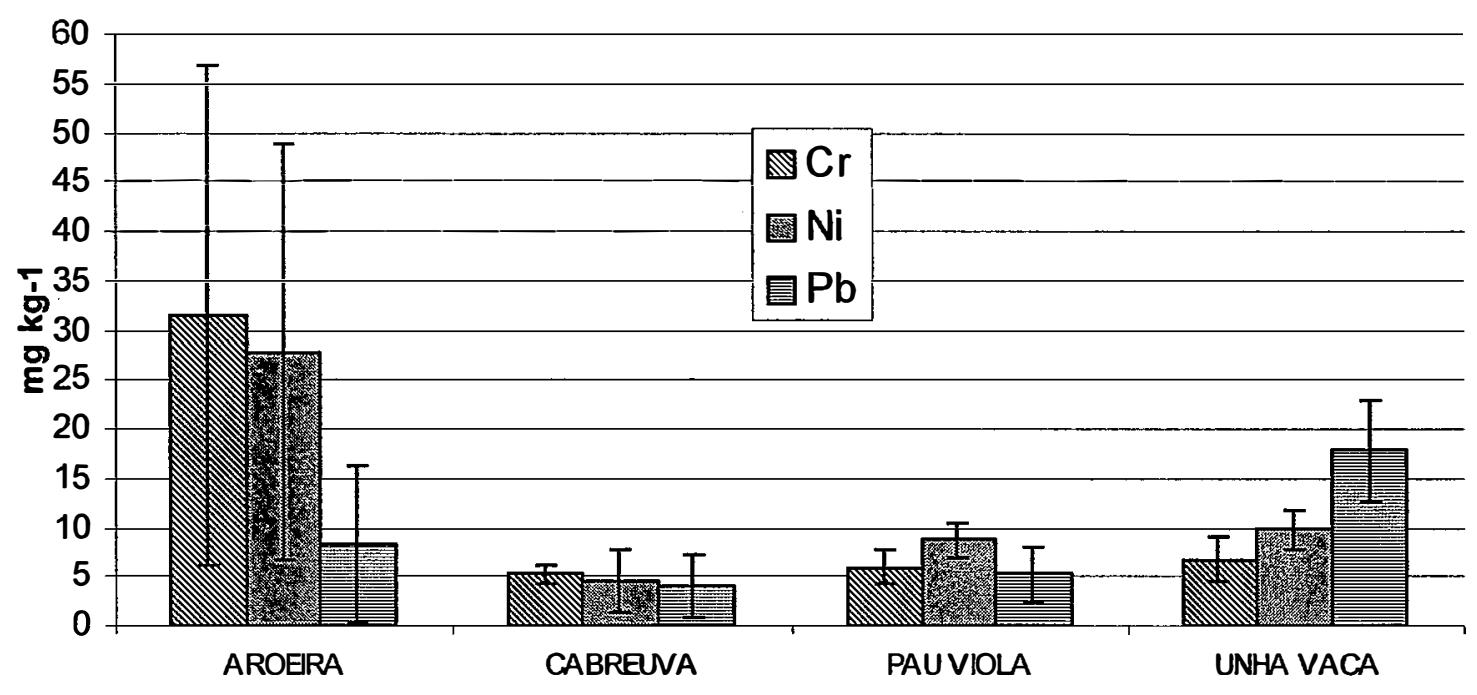

ESPÉCIES

Figura 36 - Concentrações médias de metais pesados $\left(\mathrm{mg} \mathrm{kg}^{-1}\right)$ e respectivos desvios padrão, nas raízes das quatro espécies em função da aplicação de $20,00 \mathrm{~g} \mathrm{dm}^{-3}$ de biossólido. As demais doses de biossólido promoveram concentrações de metais pesados abaixo da capacidade de detecção da metodologia utilizada

Os teores de metais pesados capazes de proporcionar surgimento de sintomas de toxicidade em plantas, segundo Melo et al, citados por Marques et al. (2001), está entre 75 e $100 \mathrm{mg} \mathrm{kg}^{-1}$ para Cromo, em $100 \mathrm{mg} \mathrm{kg}^{-1}$ para Níquel e entre $100 \mathrm{mg} \mathrm{kg}^{-1}$ a $400 \mathrm{mg} \mathrm{kg}^{-1}$ para Chumbo, respectivamente. As concentrações encontradas tanto nas folhas quanto em raízes estão abaixo destes valores e também nenhum sintoma de fitotoxicidade foi observado em nenhuma das espécies.

As concentrações em folhas são diferenciadas para cada metal pesado em cada uma das espécies, indicando seletividade na absorção e translocação dos elementos das raízes para as folhas. Não se percebe uma lógica de concentração pela posição sucessional de cada espécie. 


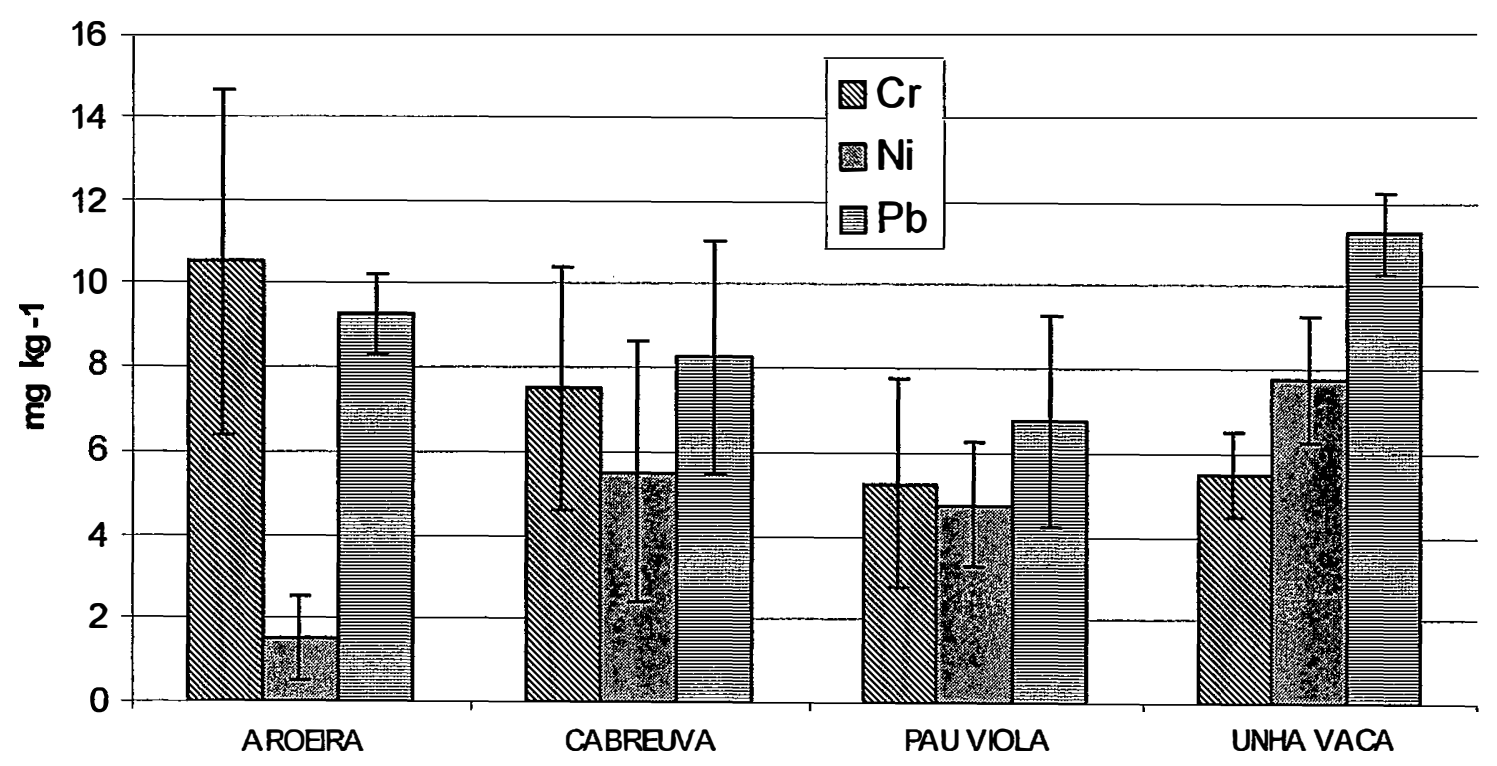

ESPÉCIES

Figura 37- Concentrações médias de metais pesados $\left(\mathrm{mg} \mathrm{kg}^{-1}\right)$ e respectivos desvios padrão nas folhas, em função da aplicação de $20,00 \mathrm{~g} \mathrm{dm}^{-3}$ de biossólido. As demais doses de biossólido promoveram concentrações de metais pesados abaixo da capacidade de detecção da metodologia utilizada

Estudando a influência da aplicação do lodo de esgoto na concentração de nutrientes na biomassa de espécies vegetais de sub bosque de um talhão de Eucaliptus grandis, Resende (2005) encontrou valores para folhas de 0,3 a 4,7 $\mathrm{mg} \mathrm{kg}{ }^{-1}$ de $\mathrm{Cr}$, de 1,3 a 4,3 $\mathrm{mg} \mathrm{kg}^{-1}$ de $\mathrm{Ni}$ e 1,0 a 2,3 $\mathrm{mg} \mathrm{kg}^{-1}$ de $\mathrm{Pb}$ para tratamento com dose de $10 \mathrm{~g} \mathrm{dm}^{-3}$ de biossólido. Percebem-se valores abaixo do encontrado neste trabalho, pela menor dosagem de biossólido aplicada e também por serem espécies diferentes.

A absorção e alocação de metais pesados nos compartimentos das plantas são bastante diferenciados para cada elemento em cada espécie. A Figura 38 exibe a relação de concentrações de metais pesados entre folhas e raízes, mostrando variações entre a espécies e entre cada metal pesado. $A$ 
cabreúva, cuja curva se mantém acima de 100, concentrou os três metais pesados em maiores quantidades nas folhas, demonstrando alta translocação. A unha-de-vaca concentrou os três metais pesados em quantidades maiores nas raizes, demonstrando baixa translocação. A aroeira e o pau-de-viola concentraram quantidades maiores de Cromo e Níquel em raízes, e quantidades maiores de chumbo na parte aérea.

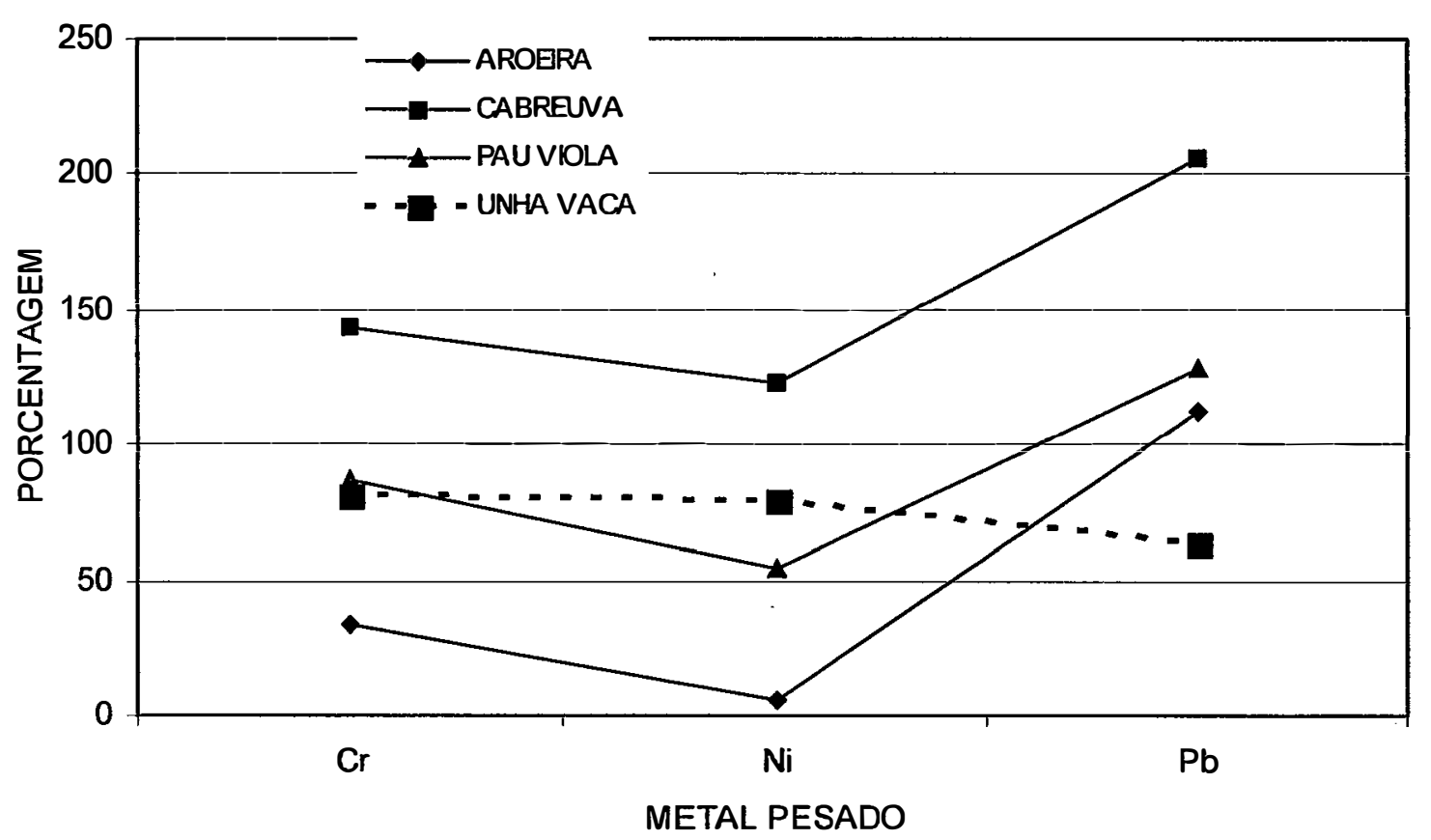

Figura 38 - Relação das concentrações de metais pesados entre folhas e raízes, em função da aplicação de $20,00 \mathrm{~g} \mathrm{dm}^{-3}$ de biossólido. As demais doses de biossólido promoveram concentrações de metais pesados abaixo da capacidade de detecção da metodologia utilizada

Estudando a toxidez de $\mathrm{Zn}, \mathrm{Cu}, \mathrm{Cd}$ e $\mathrm{Pb}$ para o eucalipto em solução nutritiva, Soares (1999) concluiu que a absorção, acúmulo e translocação são diferentes para cada elemento. Observou que $\mathrm{o} \mathrm{Pb}$ foi pouco translocado, acumulando-se nas raízes do eucalipto. 
Teixeira et al. (1998), estudando metais pesados em folhas de espécies lenhosas não observaram acúmulo de $\mathrm{Pb}$ em folhas das plantas amostradas, também demonstrando baixa mobilidade do elemento.

Observa-se que o $\mathrm{Cr}$ e o $\mathrm{Ni}$ foram pouco translocados na aroeira, paude-viola e unha-de-vaca, concentrando-se em maiores quantidades nas raízes, mas mostraram-se móveis na cabreúva. O chumbo mostrou-se bastante móvel translocando-se em maior quantidade para as folhas de aroeira, cabreúva e pau-de-viola, mas pouco móvel na unha-de-vaca. Estas observações evidenciam as dificuldades para interpretação dos efeitos dos metais pesados nas espécies quando da aplicação de biossólido.

A acumulação dos metais pesados nos tecidos pode ser vista pelas Figuras 39 e 40 .

A aroeira apresentou tendência de estoque maior de cromo e níquel nas raízes do que as outras três espécies. O chumbo teve uma tendência a se concentrar mais nas raízes de unha-de-vaca e menos em cabreúva.

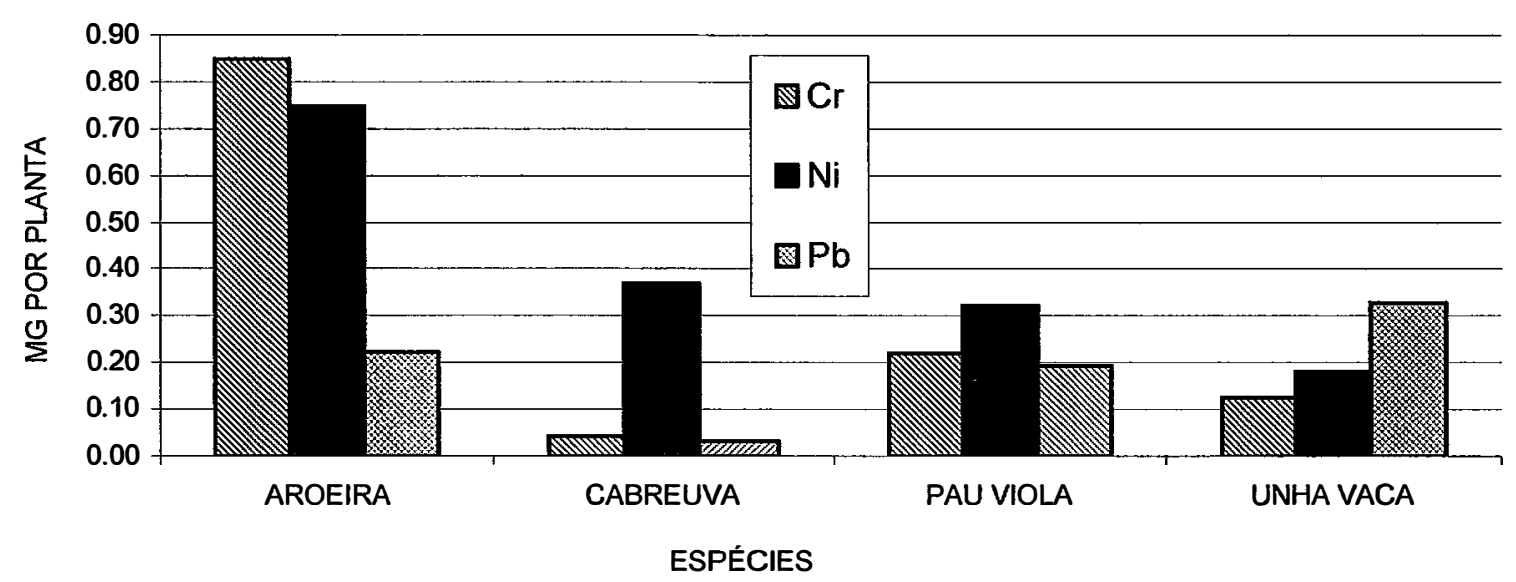

Figura 39 - Estoque de metais nas raizes das quatro espécies (mg planta $\left.{ }^{-1}\right)$, em função da aplicação de $20,00 \mathrm{~g} \mathrm{dm}^{-3}$ de biossólido. As demais doses de biossólido promoveram concentrações de metais pesados abaixo da capacidade de detecção da metodologia utilizada 
O estoque de cromo e chumbo nas folhas tendeu a ser maior na aroeira, do que nas outras três espécies. $O$ estoque de níquel apresentou tendência a ser menor nas folhas do que em raízes.

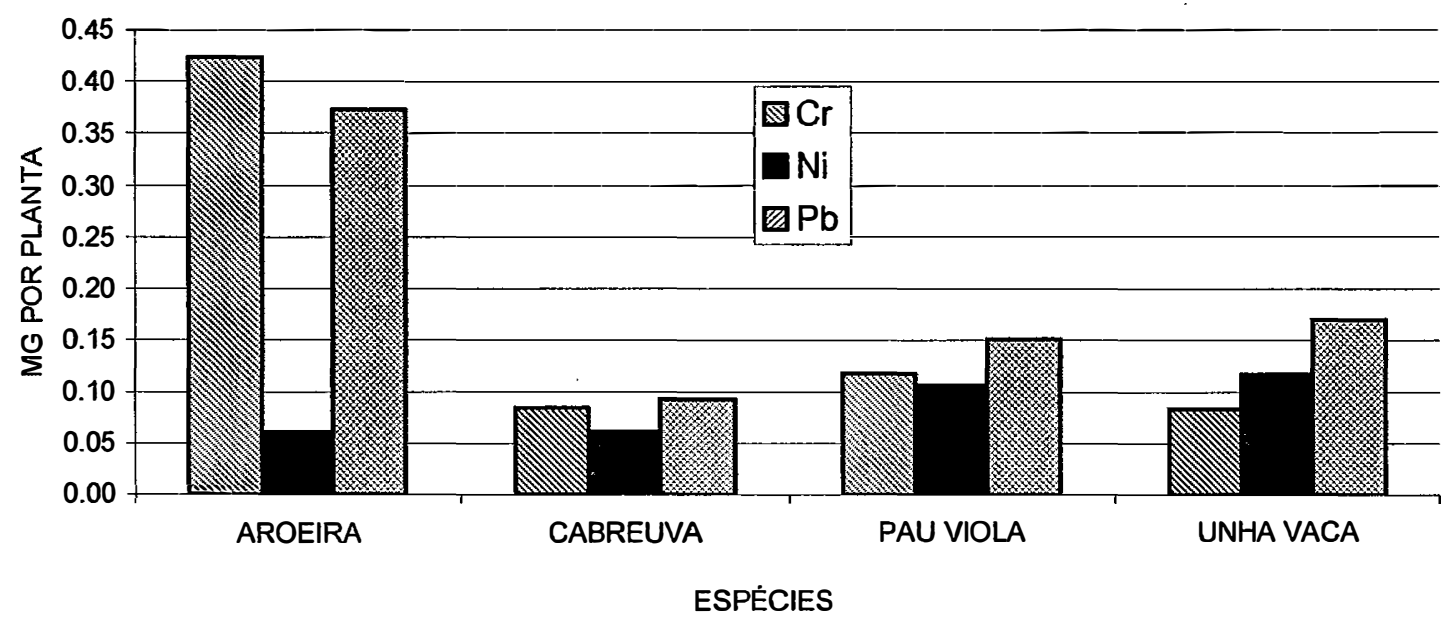

Figura 40 - Estoque de metais pesados nas folhas das quatro espécies, em função da aplicação de $20,00 \mathrm{~g} \mathrm{dm}^{-3}$ de biossólido. As demais doses de biossólido promoveram concentrações de metais pesados abaixo da capacidade de detecção da metodologia utilizada

As taxas de transferência dos metais pesados encontrados no biossólido para os tecidos das espécies tratadas podem ser vistas pela Tabela 66. Do total administrado no tratamento com maior quantidade de biossólido $\left(20 \mathrm{~g} \mathrm{dm}^{-3}\right)$, percebem-se valores baixos de transferência, sendo o valor máximo de $3,89 \%$ para o chumbo. 
Tabela 66 - Taxa de transferência de metais pesados (\%) nas quatro espécies, em função da aplicação de $20,00 \mathrm{~g} \mathrm{dm}^{-3}$ de biossólido. As demais doses de biossólido promoveram concentrações de metais pesados abaixo da capacidade de detecção da metodologia utilizada

\begin{tabular}{lcrrrrrrrrr}
\hline ESPÉCIE & \multicolumn{3}{c}{ Cr } & \multicolumn{3}{c}{ Ni } & \multicolumn{3}{c}{ Pb } \\
& RAIZ & FOLHA & R +F & RAIZ & FOLHA & R + F & RAIZ & FOLHA & R + F \\
\hline AROEIRA & 1.52 & 0.76 & 2.27 & 2.96 & 0.24 & 3.20 & 1.45 & 2.44 & 3.89 \\
CABREUVA & 0.08 & 0.15 & 0.23 & 1.46 & 0.24 & 1.70 & 0.21 & 0.60 & 0.82 \\
PAU VIOLA & 0.39 & 0.21 & 0.60 & 1.27 & 0.42 & 1.69 & 1.26 & 0.99 & 2.25 \\
UNHA VACA & 0.22 & 0.15 & 0.37 & 0.71 & 0.46 & 1.18 & 2.15 & 1.11 & 3.26 \\
\hline
\end{tabular}

Entre as espécies, a aroeira foi a que mais concentrou metais pesados, sendo o $\mathrm{Cr}$ e Ni transferido para as raízes e chumbo para as folhas. $\mathrm{O}$ pau-deviola e unha-de-vaca acumularam mais os três elementos em suas raízes. $A$ cabreúva acumulou mais $\mathrm{Cr}$ e $\mathrm{Pb}$ nas folhas e níquel nas raízes.

Labrecque et al (1995) encontraram taxa de transferência de níquel para Salix discolor e Salix viminalis de 4,38 e 5,27 \%, respectivamente, para tratamento com dose de de $20 \mathrm{~g} \mathrm{dm}^{3}$ biossólido, pouco acima do encontrado para as espécies utilizadas neste trabalho.

Podemos concluir que a aplicação de biossólido classe $A$ no cultivo de árvores é bastante seguro nas dosagens estudadas, pelo seu baixo teor no biossólido e pela sua baixa taxa de transferência para os tecidos das árvores, não impondo riscos de contaminação às pessoas e animais que convivem com as árvores em vias públicas nas áreas urbanas.

\subsection{Considerações finais}

Os dados obtidos e trabalhados e os resultados alcançados evidenciam que o biossólido pode vir a ser um precioso insumo na produção de mudas de árvores nativas utilizadas na arborização urbana. 
De forma geral, observou-se que o uso de doses crescentes de biossólido no cultivo de mudas de árvores nativas em potes promoveu:

1) Aumento nos estoques de nitrogênio em seus tecidos, principalmente nas folhas, embora a concentração não tenha se elevado por ter-se diluído na matéria seca produzida em maior quantidade nos tratamentos com maiores doses de biossólido. Suas concentrações mantiveram-se normais, dentro dos padrões técnicos.

2) Aumento nas concentrações e estoques de fósforo nos tecidos das árvores, que foram maiores nas raízes, com suas concentrações na faixa considerada tecnicamente como normal ou suficiente para seu desenvolvimento;

3) Redução nas concentrações de potássio em seus tecidos, mas aumento dos estoques, evidenciando efeito de diluição na matéria seca nas maiores doses de biossólido. As concentrações do nutriente estavam dentro de limites normais, pela sua suplementação com cloreto de potássio solúvel, embora os resultados significativos para $20 \mathrm{~g} \mathrm{dm}^{-3}$ indiquem que o biossólido forneceu parte significativa do nutriente.

4) Aumento nos estoques de cálcio, principalmente em suas folhas, indicando ser boa fonte do nutriente, mesmo não tendo cal no seu processo de floculação e ter sido usado calcário em todos os potes. Suas concentrações também estavam dentro dos limites técnicos considerados normais;

5) Redução nas concentrações de magnésio e aumento em seus estoques nas plantas, maiores nas folhas. Isto evidencia diluição do nutriente na matéria seca produzida em maior quantidade em resposta às maiores dosagens, 
demonstrando ter fornecido quantidade significativa do nutriente, a despeito da calagem efetuada em todos os potes com calcário dolomítico;

6) Aumento nos estoques de enxofre, principalmente em suas folhas. As concentrações mantiveram-se dentro dos limites técnicos normais;

7) Aumento nas concentrações e estoques de zinco principalmente nas raízes, mas dentro dos limites normais;

8) Aumento nos estoques de cobre, principalmente nas raízes, com concentrações na faixa técnica normal;

9) Aumento nas concentrações e estoques de manganês, com concentrações maiores nas folhas. As concentrações mantiveram-se nos limites normais;

10) As concentrações e estoques de ferro não foram afetados pelos tratamentos, sendo suas concentrações nos tecidos das plantas consideradas altas, dentro da faixa fitotóxica;

11) As concentrações de boro foram reduzidas e os estoques não foram alterados significativamente. As concentrações ficaram na faixa técnica de deficiência.

12) Os estoques de metais pesados nos tecidos das plantas mantiveram-se dentro dos níveis normais, sendo o de cromo e níquel em maior quantidade nas raízes, e o chumbo, nas folhas. 
13) A dose de $20 \mathrm{~g} \mathrm{dm}^{-3}$ promoveu respostas equivalentes à da adubação mineral, podendo substituí-la, sem contudo dispensar a suplementação com boro e potássio solúveis;

As espécies nativas apresentaram um comportamento bastante distinto, tanto na produção de matéria seca, quanto no uso dos nutrientes, em resposta ao aumento das doses de biossólido:

1- A aroeira (Schinus terebinthifolia Raddi), espécie de início de sucessão, apresentou, entre as quatro espécies, o maior crescimento em altura, em diâmetro de colo e em produção de matéria seca. Também apresentou as menores concentrações e os maiores estoques de macronutrientes e as maiores concentrações de micronutrientes e metais pesados;

2- $\quad$ A cabreúva (Myroxylon peruiferum L. f.), espécie de final de sucessão, apresentou os menores crescimentos em altura, diâmetro de colo e produção de matéria seca. Apresentou também as maiores concentrações e menores estoques de macronutrientes, micronutrientes e metais pesados;

3- O pau-de-viola (Cytarexyllum myrianthum Cham) e a unha-de-vaca (Bauhinia forficata Link), espécies de início de sucessão, mantiveram-se numa posição intermediária tanto na produção de matéria seca, quanto no uso de macro, micronutrientes e de metais pesados. 


\section{CONCLUSÕES}

Considerando as hipóteses iniciais deste trabalho, podemos concluir que:

1- $\quad$ O biossólido peletizado utilizado no cultivo de mudas florestais nativas em potes demonstrou ser boa fonte de nutrientes, com baixo teor e baixas taxas de transferência de metais pesados para as plantas. Assim sendo, possui grande potencial de uso seguro na arborização urbana.

2- A aplicação de doses crescentes de biossólido promoveu aumento no crescimento das quatro espécies nativas estudadas - Aroeira pimenteira (Schinus terebinthifolia Raddi), Cabreúva (Myroxylon peruiferum L. f.), Pau-deviola (Cytarexyllum myrianthum Cham) e Unha-de-vaca (Bauhinia forficata Link) - e conseqüente aumento na produção de matéria seca. A maior dose de biossólido $\left(20 \mathrm{~g} \mathrm{dm}^{-3}\right)$ promoveu respostas em crescimento equivalentes à promovida pela adubação mineral. A aroeira, o pau-de-viola e a unha-de-vaca, espécies de início de sucessão, apresentaram os maiores resultados em crescimento e produção de matéria seca quando comparados à cabreúva, espécie de final de sucessão.

3- O biossólido mostrou ser boa fonte de macro e micronutrientes às quatro espécies estudadas. Mesmo considerando a suplementação do potássio, por estar presente em menores quantidades no biossólido, o aumento das doses promoveu aumento significativo dos seus estoques nos tecidos das quatro 
espécies estudadas. Entre os micronutrientes, o boro foi o único elemento que não foi alterado pelas doses crescentes de biossólido, ficando na faixa de deficiência, devendo ser suplementado por fonte solúvel. As concentrações de ferro nas plantas também não foram significativamente afetadas pela aplicação de doses crescentes de biossólido, pela sua alta concentração no solo.

As taxas de transferência de metais pesados, presentes no biossólido, para as quatro espécies estudadas foram baixas, mantendo as concentrações nos seus tecidos abaixo da faixa fitotóxica. 


\section{REFERÊNCIAS BIBLIOGRÁFICAS}

ALEM SOBRINHO, P.A. Tratamento de esgoto e geração de lodo. In:TSUTIYA, J.T.;COMPARINI, J. B.; HESPANHOL, I.; CARVALHO, P. C. T,; MELFI, A. J.; MELO, V. J. ; MARQUES, M. O. (Ed). Biossólidos na Agricultura. São Paulo: SABESP, 2001. cap. 2, p. 7-40.

ANDREOLI, C. V.; PEGORINI, E. S.Gestão pública do uso agrícola do lodo de esgoto. . In: BETTIOL, W. ; CAMARGO, O. A. Impacto Ambiental do uso agrícola do lodo de esgoto. Jaguariúna, SP: EMBRAPA meio ambiente, 2000, cap. 18, p 281-312.

AYERS, R,S. ; WESTCOT, D.W. A qualidade da água na agricultura. Trad. de Ghei H. R.; Medeiros, J. F. ; Damasco, F. A. Campina Grande: UFPB, 1991. (Estudos FAO: irrigação e drenagem), 29 p.

BARBOSA, L.M. considerações gerais e modelos de recuperação de formações ciliares. In: RODRIGUES, R.R.; LEITĀO FILHO, H. F. (Ed.). Matas Ciliares: Conservação e recuperação. São Paulo: Editora da Universidade de São Paulo: Fapesp, 2000. cap. 15.4, p. 289-312. 
BARBOSA, L.M.; ASPERTI, L.M. ; BARBOSA, J.M. "Características importantes de componentes arbóreos na definição dos estágios sucessionais em florestas implantadas". In: SIMPÓSIO INTERNACIONAL DE ECOSSISTEMAS FLORESTAIS, 4., Foz do Iguaçu, 1996. Anais.Foz do Iguaçu: UFPR, 1996. p. 242-245.

BARRETO, M.C.V. Degradação da fração orgânica: resíduos e efeitos em algumas propriedades químicas e físicas de dois solos. Piracicaba, 1995. 106 p. Tese (Doutorado) - Escola Superior de Agricultrua "Luiz de Queiroz", Universidade de São Paulo.

BATTISTEL, P; PINAMONTI, F; VIECELI,A; ZORI, G. Effects of compost on container grown forest trees. Monti e Boschi, v. 44, n.2, p 34-40, 1993.

BERTON, R. S. Riscos de contaminação do agroecossistema com metais pesados. In: BETTIOL, W. ; CAMARGO, O. A. Impacto Ambiental do uso agrícola do lodo de esgoto. Jaguariúna, SP: EMBRAPA meio ambiente, 2000 , cap. 16 , p. $259-268$.

BONNET, B.R.P; WISNIEWSKI, C; REISSMANN, C.B; LEE, D.J. Effects of substrates composed of biossólids on the production of E. viminalis, Schinus terebinthifolius e Mimosa scabrela seedlings and on the nuitritional status of S. terebinthifolius seedlings. Water Science and Technology, v. 46, n. 10, p.239-246, 2002.

BUDOWSKI, G. "Distribution of Tropical American rain forest Species in the Light of Sucessional Progres". Turrialba, n. 15, p. 40-42, 1965. 
CARDOSO, E.J.B.N.; NETO, P.F. Aplicabilidade do biossólido em plantações florestais: III. Alterações microbianas no solo. In: BETTIOL, W. ; CAMARGO, O. A. Impacto Ambiental do uso agrícola do lodo de esgoto. Jaguariúna, SP: EMBRAPA meio ambiente, 2000.Cap. 10. p. 197-208, 2000.

CARVALHO, P. C. T.; CARVALHO, F. J. P. C. Legislação sobre biossólidos.In:TSUTIYA, J.T.;COMPARINI, J. B.; HESPANHOL,I.; CARVALHO, P. C. T.; MELFI, A. J.; MELO, V. J. ; MARQUES, M. O. (Ed). Biossólidos na Agricultura. São Paulo: SABESP, 2001. cap. 7, p. 209-226, 2000.

CESTARO, L. A. A vegetação no ecossistema urbano. In: ENAU - ENCONTRO NACIONAL DE ARBORIZAÇÃO URBANA, 1., Poá: SBAU, 1985. Anais. Poá, 1985. p. 51-56.

CETESB (Companhia de Tecnologia de Saneamento Ambiental). Aplicação de lodos de sistemas de tratamento biológico em áreas agrícolas critérios para projeto e operação. São Paulo: CETESB, 1999. 35 p. (Manual Técnico- Norma P 4.230).

CUNHA, R.C.A.; NETO, V.A.; Fundamentos teóricos do processo de avaliação de risco. In: BETTIOL, W. ; CAMARGO, O. A. Impacto Ambiental do uso agrícola do lodo de esgoto. Jaguariúna, SP: EMBRAPA meio ambiente, 2000, cap. 14, p. 227-243, 2000.

Departamento de Águas e Energia Elétrica - DAEE. Progama Somando Verde. São Paulo: DAEE, 1992, 21 p. 
DESCHAMPS, C; SALLES, R. F. M.; Avaliação do lodo de esgotos como fertilizante orgânico em culturas anuais e perenes. Curitiba: SANEPAR. Projeto interdisciplinar para definição de critérios sanitários, agronômicos e ambientais para a implantação da reciclagem agrícola do lodo de esgoto. Curitiba: SANEPAR, 1996, 29 p.

ELETRICIDADE DE SÃO PAULO - ELETROPAULO. Guia de planejamento e manejo da arborização urbana. São Paulo: Eletropaulo: Cesp: CPFL, 1995. $40 \mathrm{p}$.

FERNANDES, F. Estabilização e higienização de biossólidos. In: BETTIOL, W. ; CAMARGO, O. A. Impacto Ambiental do uso agrícola do lodo de esgoto. Jaguariúna: EMBRAPA meio ambiente, cap. 3, 2000.p.45-68.

GONÇALVES, J.L. M. Recomendações de Adubação para Eucalyptus, Pinus e Espécies Nativas da Mata Atlântica. Documentos Florestais, n. 15, p.1-23, 1995.

GONÇALVES, J.L.M.; SANTARELLI, E.G.; MORAES NETO, S.P.; MANARA, M.P. Produção de mudas de espécies nativas: substrato, nutrição, sombreamento e fertilização. In: GONÇALVES, J.L.M.; BENEDETTI, V. (Ed.). Nutrição e fertilização florestal. Piracicaba: IPEF, 2000a, cap. 11, p. 309-350.

GONÇALVES, J.L.M.; VAZ,L. M.S.; AMARAL,T.M.; POGGIANI, F. Aplicabilidade de biossólido em plantações florestais: II. Efeito na fertilidade do solo, nutrição e crescimento das árvores. In: BETTIOL, W. ; CAMARGO, O. A. Impacto Ambiental do uso agrícola do lodo de esgoto. Jaguariúna, SP: EMBRAPA meio ambiente, 2000b. p. 179-195. 
GONÇALVES, J.L.M.; FREIXÊDAS, V.M.; KAGEYAMA, P.Y.; GONÇALVES, J.C; DIAS, J.H. Produção de biomassa e sistema radicular de espécies de diferentes estágios sucessionais. Revista Instituto Florestal, n. 4, p. 363367, 1992.

GONÇALVES, W. Floresta Urbana. Ação Ambiental. Viçosa: UFV, 2000. p 1719.

GOUIN, F.R; WALKER, J.M. Deciduous tree seedling response to nursery soil amended with composted sewadge sludge. Hort Science, v.12, n.1, p 4547,1977 .

GUEDES, M. C. Efeito do lodo de esgoto (biossólido) sobre a nutrição, ciclagem de nutrientes e crescimento de sub-bosque, em plantação de eucalipto. Piracicaba, SP, 2000. 74 p. Dissertação (Mestrado) - Escola Superior de Agricultura "Luiz de Queiroz", Universidade de São Paulo.

GUEDES, M. C. Ciclagem de Nutrientes após aplicação de lodo de esgoto (biossólido) sobre latossolo cultivado com Eucalyptus Grandis. Piracicaba, SP, 2005. 154 p. Tese (Doutorado) - Escola Superior de Agricultura "Luiz de Queiroz", Universidade de São Paulo.

HARRISON, R.; XUE, D.; HENRY, C.; COLE, D. W. Long-term effects of heavy applications of biosolids on organic matter and nutrinet content of a coarsetextured forest soil.Forest Ecology and Management, v. 66, p. 165-177, 1993.

HAYWARD, K. Applied soil science. Water Quality International. v. 6, p.42-45, jan/feb, 1998. 
HENRY, L. C.; COLE, D. W.; HARRISON, R.B. The use of municipal sludge to restore and improve site productivity in forestry: The Pack Forest Sludge Reserch Program.Forest Ecology and Management, v. 66, p. 137-139, 1993a.

HENRY, L. C.; COLE, D. W.; HARRISON, R.B. The use of municipal and pulp and paper sludges to increase production in forestry. Jornal of sustainable forestry, n.1, cap. 3, p. 41-55, $1993 \mathrm{~b}$.

HESPANHOL, I. Biossólidos, meio ambiente e saúde pública: critérios para o estabelecimento de diretrizes.In:TSUTIYA, J.T.;COMPARINI, J. B.; HESPANHOL, I.; CARVALHO, P. C. T,; MELFI, A. J.; MELO, V. J. ; MARQUES, M. O. (Ed). Biossólidos na Agricultura. São Paulo: SABESP, 2001,cap. 10, p. 273-287.

ILHENFELD, R. G; ANDREOLI, C. V. ; DOMASZAK, C. S. Uso e manejo de lodo de esgoto na agricultura. Rio de Janeiro: PROSAB - Programa de Pesquisa em Saneamento Básico, 1999. 97 p.

KABATA-PENDIAS, A.; PENDIAS, H. Trace Elements in Soils and Plants. Boca Raton: CCR Press, 1986. 315 p.

KAGEYAMA, P. Y; GANDARA, F.B. Recuperação de áreas ciliares. In: RODRIGUES, R.R; LEITÃO FILHO, H. F.(Ed.). Matas Ciliares: Conservação e Recuperação. São Paulo: Editora da Universidade de São Paulo: Fapesp, 2000, cap. 15.2. p.249-269. 
KAGEYAMA, P.Y.; SANTARELLI, E.; GANDARA, F.B.; GONÇALVES, J. C. Restauração de áreas degradadas: Modelos de consorciação com alta diversidade. In: SIMPÓSIO NACIONAL SOBRE RECUPERAÇÃO DE ÁREAS DEGRADADAS, 2., Foz do Iguaçu, 1994. Anais, p. 569-576. Foz do Iguaçu: UFPR, 1994.

KRAMER, P. J; KOZLOWSKI, Th. T. Physiology of woody plants. New York: Academic Press, 1979. 811p.

LABRECQUE, M.; TEODORESCU, T.I.; DAIGLE, S. Effect of wastewater sludge on growth and heavy metal bioaccumulation on two Salix espécies. Plant and Soil, v. 17, n. 1/2, p. 303-316, 1995.

LARCHER, W. Ecofisiologia vegetal. Trad. Prado, C.H.B.A. São Carlos: Rima Artes e Textos, 2000.531 p.

LOPES, E.B.M. Diversidade metabólica em solo tratado com biossólido. Piracicaba, 2002. Dissertação (Mestrado) - Escola Superior de Agricultura "Luiz de Queiroz", Universidade de São Paulo.

LORENZI, H. Árvores Brasileiras: manual de identificação e cultivo de plantas arbóreas nativas do Brasil. 2 Ed. Nova Odessa, SP: Editora Plantarum, 1998. $352 \mathrm{p}$.

LUDUVICE, M. Experiência da companhia de saneamento do Distrito Federal na reciclagem agrícola de biossólido. . In: BETTIOL, W.; CAMARGO, O. A. Impacto Ambiental do uso agrícola do lodo de esgoto. Jaguariúna, SP: EMBRAPA meio ambiente, 2000, cap. 7, p. 153-162. 
MARQUES, M. O.; MELO, W. J.; MARQUES, T. A. Metais pesados e o uso de biossólidos na agricultura. .In:TSUTIYA, J.T.;COMPARINI, J. B.; HESPANHOL, I.; CARVAlHO, P. C. T,; MELFI, A. J.; MELO, V. J. ; MARQUES, M. O. (Ed). Biossólidos na Agricultura. São Paulo: SABESP, 2001,cap. 12, p. 365-403.

MATTIAZZO, M.E.; ANDRADE, C.A. Aplicabilidade do biossólido em plantações florestais: IV. Lixiviação de $\mathrm{N}$ inorgânico e toxicidade de metais pesados. In: BETTIOL, W. ; CAMARGO, O. A. Impacto Ambiental do uso agrícola do lodo de esgoto. Jaguariúna, SP: EMBRAPA meio ambiente, 2000, cap. 11, p. 203-208.

MELO, W. J.; MARQUES, M. O.; MELO, V. P. O uso agrícola do biossólido e as propriedades do solo. In:TSUTIYA, J.T.; COMPARINI, J. B.; HESPANHOL, I.; CARVALHO, P. C. T.; MELFI, A. J.; MELO, V. J. ; MARQUES, M. O. (Ed.). Biossólidos na Agricultura. São Paulo: SABESP, 2001. Cap. 11, p.289-363.

MIKI, K. M.; ANDRIGUETI, E. J.; SOBRINHO, P.A.Tratamento da fase sólida em estações de tratamento de esgotos. In:TSUTIYA, J.T.;COMPARINI, J. B.; HESPANHOL, I.; CARVALHO, P. C. T,; MELFI, A. J.; MELO, V. J. ; MARQUES, M. O. (Ed). Biossólidos na Agricultura. São Paulo: SABESP, 2001. Cap. 3. p.41-87.

MILLER, R. W. Urban Forestry: planning and managing urban grenspaces. Upper Saddle River, New Jersey, USA: Prentice Hall, 1996, 502 p.

OLIVEIRA, J.B.; CAMARGO, M.N.; ROSI, M.; CALDERANO FILHO, B. Mapa Pedológico do Estado de São Paulo. Campinas: IAC/EMBRAPACNP SOLOS, 1999, 64 p., 4 mapas. 
PEDROSA, J.P.; HAANDEL, A. C.; BELTRÃO, N.E.M.; DIONÍSIO, J.A.; Produção e componentes do algodão herbáceo, em função da aplicação de biossólidos. Revista Brasileira de Engenharia Agrícola e Ambiental, v.7, n.3, p. 483-488, 2003.

POGGIANI, F. Uso de biossólidos produzidos nas estações de tratamento de esgoto da região metropolitana de São Paulo em plantações florestais.. Piracicaba: FEALQ, 2003. 38p. (Relatório de pesquisa).

POGGIANI, F.; GUEDES, M.C.; BENEDETTI, V. Aplicabilidade de biossólido em plantações florestais: I. Reflexos no ciclo de nutrientes. In: BETTIOL, W.; CAMARGO, O. A. Impacto Ambiental do uso agrícola do lodo de esgoto. Jaguariúna, SP: EMBRAPA meio ambiente, cap. 8, p. 163-178, 2000.

PRADO, H. Os solos no Estado de São Paulo: mapas pedológicos. Piracicaba: Helio Prado, 1997. 205 p.

RESENDE, C. I. O. Influência da aplicação do lodo de esgoto (biossólido) sobre a concentração e o estoque de nutrientes na biomassa do sub-bosque, na serapilheira e no solo de um talhão de Eucalyptus grandis. Piracicaba, SP, 2005. 81 p. Dissertação (Mestrado) - Escola Superior de Agricultura "Luiz de Queiroz", Universidade de São Paulo.

RIEKERK, $\mathrm{H}$. Effects of sludge disposal on drainage solutions of two forest soils. Forest Science, v. 27, n. 4, p. 792-800, 1981.

ROMANOV, E. M. Reaction of seedlings of woody plants to the application of sewage sludges to the soil. Lesovedenio, n. 6, p. 22-29, 1997. 
SABESP (COMPANHIA DE SANEAMENTO BÁSICO DO ESTADO DE SÃO PAULO). Projeto Tietê. Revista Engenharia, n. 527, p. 82-90, 1998.

SARRUGE, J.R.; HAAG, H.P. Análise química em plantas. Piracicaba: ESALQ/USP.1974. 56p.

SOARES, C. R. F. S. Toxidez de Zinco, Cobre, Cádmio e Chumbo para o eucalipto em solução nutritiva. Lavras, MG, $1999.132 p$. Dissertação(Mestrado) - Universidade Federal de Lavras.

SOCCOL, V. T.; PAULINO, R. C. Riscos de contaminação do agroecossistema com parasitos pelo uso do lodo de esgoto.In: BETTIOL, W.;CAMARGO, O. A. Impacto Ambiental do uso agrícola do lodo de esgoto. Jaguariúna, SP: EMBRAPA meio ambiente, 2000, cap. 15, p 245-258.

SPURR, S. H. ; BARNES, B. V. Forest Ecology. New York: John Wiley, 1980. $687 p$.

STONE, D.M; POWERS, H.R. Sewage sludge increases early growth and decrease Fusiform rust infection of nursery- run and rust resistant loblolly pine. Southern Journal of applied forestry, v.13, n.2, p. 68-71. 1989.

STRAUS, E. L.; Normas da utilização de lodos de esgoto na agricultura. In: BETTIOL, W. ; CAMARGO, O. A. Impacto Ambiental do uso agrícola do lodo de esgoto. Jaguariúna, SP: EMBRAPA meio ambiente, 2000, cap. 13, p. 215-224.

TEIXEIRA, W. A. ; LEMOS FILHO, J.P. Metais pesados em folhas de espécies lenhosas colonizadoras de uma área de mineração de ferro em Itabirito, Minas Gerais. Revista Árvore. v. 22, n. 3, p. 381-387, 1998. 
TRIGUEIRO, R.M.;GUERRINI, I.A. Uso de Biossólido como substrato para produção de mudas de eucalipto. Scientia Forestalis, n. 64, p. 150-162, 2003.

TSUTYA, M. T. Alternativas de disposição final de biossólidos gerados em estações de tratamento de esgotos. Impacto ambiental do uso do lodo de esgoto/ Editores Wagner Bettiol e Otávio A. Camargo. - Jaguraiúna, SP: EMBRAPA Meio Ambiente, 2000. p.69-105.

TSUTIYA, M. T. Características de biossólidos Gerados em Estações de Tratamento de Esgoto. In:TSUTIYA, J.T.;COMPARINI, J. B.; HESPANHOL, I.; CARVALHO, P. C. T,; MELFI, A. J.; MELO, V. J. ; MARQUES, M. O. (Ed). Biossólidos na Agricultura. São Paulo: SABESP, 2001. cap. 4, p. 89-131.

USDA (United State Department of Agriculture). Report and recommendation on organic farming. Washington, U.S. Government (1980). 94 p.

VANZO, J. E. Horizonte histórico da reciclagem.In:TSUTIYA, J.T.;COMPARINI, J. B.; HESPANHOL, I.; CARVALHO, P. C. T,; MELFI, A. J.; MELO, V. J. ; MARQUES, M. O. (Ed). Biossólidos na Agricultura. São Paulo: SABESP, 2001. cap. 1, p. 1-5.

VIEIRA, R.F.; TSAI, S.M.; TEIXEIRA, M.D. Efeito do lodo de esgoto no crescimento e fixação simbiótica de $\mathrm{N}_{2}$ em feijoeiro (Phaseolus vulgaris). Boletim de Pesquisa e Desenvolvimento. n. 19, 18 p. , 2004. 
WEETMAN, G. F; MAcDONALD, M.A.; PRESCOTT, C.E.; KIMMINS, J.P. Responses of western hemlock, Pacific silver fir, and western red cedar plantations on northern Vancover Island to applications of sewage sludge and inorganic fertilizer. Canadian Journal of Forestry researsh, v. 23, n. 9, p. 1815-1820, 1993.

WEN, G.; WINTER, J.P.; VORONEY, R. P.; BATES, T. E. Potassium availability of sewadge, and sludge and manure composts in field experiments. Nutrient Cycling in Agroecossylstens, v. 47, p. 233-241, 1997. 